Szegedi Tudományegyetem

Bölcsészettudományi Kar

\title{
BÉCS SZEREPE MUNKÁCSY MIHÁLY ÉLETÉBEN
}

\author{
egyetemi doktori értekezés
}

Készítette: Polenyák Ivett

Témavezető: Dr. Deák Ágnes

$\mathrm{PhD}$., egyetemi docens

Szeged, 2014 


\section{Tartalomjegyzék}

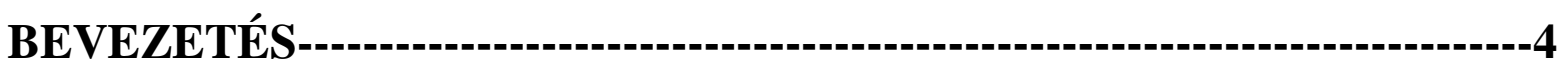

1. MUNKÁCSY MIHÁLY CSALÁDI HÁTTERE------------------ 12

1.1 MUNKÁCSY MIHÁLY CSALÁDJA AZ 1820 - 1840-ES ÉVEK KÖZÖTT ................................................. 12

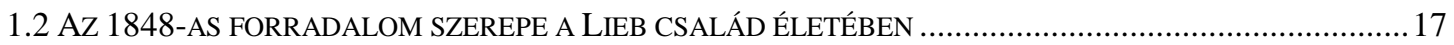

1.3 MUNKÁCSY MIHÁLY CSALÁDJA EREDETÉNEK ÚJABB LEHETSÉGES MAGYARÁZATA.........................20

\section{ESZMÉLET, AVAGY A MAGYAR MÜVÉSZET INTÉZMÉNYES KERETEINEK KIALAKULÁSA ÉS MUNKÁCSY MIHÁLY PÁLYAKEZDÉSE}

2.1 AZ ELSÖ POLGÁRI DOMINANCIÁVAL FORMÁLÓDOTT MÜVÉSZETI EGYESÜLETEK EURÓPA HORIZONTJÁN.

2.1.1 Az elöfutárok.

2.2 A MONARCHIA KÉT NAGY MÜVÉSZETI EGYLETE: A BÉCSI MÜVÉSZETI EGYLET ÉS A PESTI MÜEGYLET

2.3.1 A Bécsi Müvészeti Egylet' .............................................................................................. 30

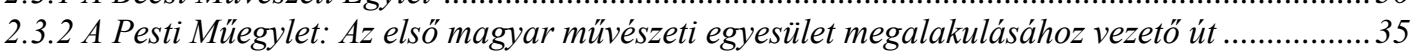

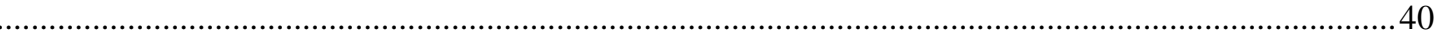

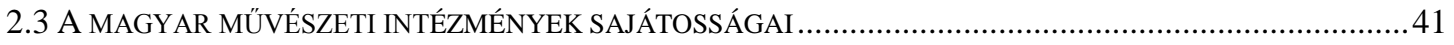

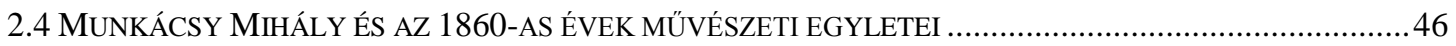

\section{BÉCS ÉS KARL RAHL SZEREPE --- 50}

3.1 A BÉCSI KÉPZŐMÜVÉSZETI AKADÉMIA ÉS KARL RAHL MAGÁNISKOLÁJA ......................................50

3.1.1 Karl Rahl szerepe a magyar és osztrák müvészetben ............................................................51

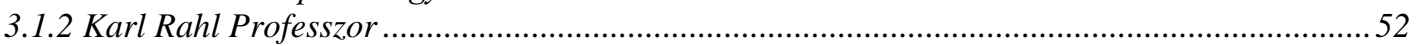

3.1.3 A provizórium első hat hónapja a Bécsi Akadémián (1850-1851) ........................................58

3.1.4 Karl Rahl legtehetségesebb magyar tanítványai: Than Mór és Lotz. Károly...........................60

3.2 KARL RAHL UTOLSÓ MAGYAR TANíTVÁNYA: MUNKÁCSY MIHÁLY ................................................64

3.2.1 Rahl professzor tanításainak hatása Munkácsy Mihályra ....................................................64

3.2.2 Rahl aláfestési technikája, a „grau in grau“, és ennek hatása Munkácsy festészetére .............69

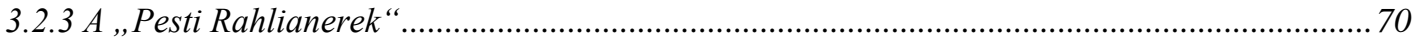

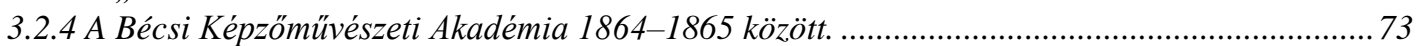

3.4 KARL RAHL ÉS MUNKÁCSY MiHÁLY KAPCSOLATA.................................................................. 74

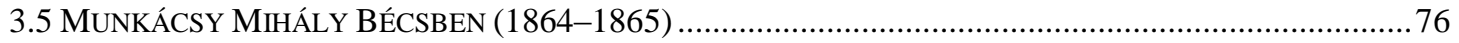

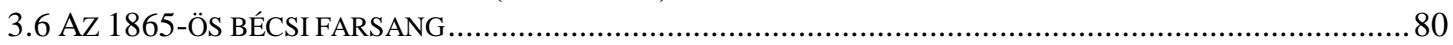

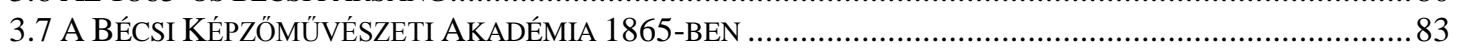

3.7.1 A Bécsi Képzőmüvészeti Akadémia elökészítö osztálya ......................................................8 83

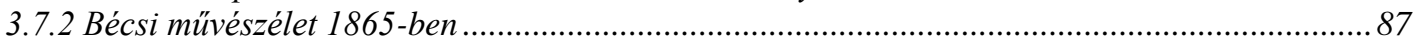

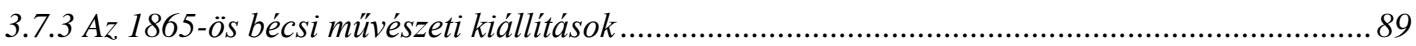

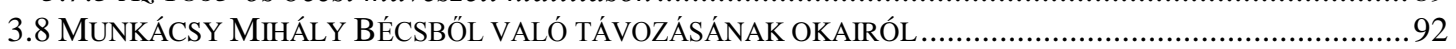

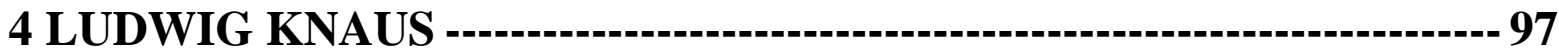

4.1 LUDWIG KNAUS MÜVÉSZETÉNEK SÚLYA MUNKÁCSY MIHÁLY ÚTKERESÉSÉBEN ..............................97

4.2 A KIEGYEZÉS ÉS ANNAK POZITÍV HATÁSAI A MAGYAR MÜVÉSZETI ÉLETRE .................................. 100

4.3 A MÜNCHENI MÜVÉSZEK HATÁSA MUNKÁCSY MÜVÉSZETÉRE ............................................... 103

4.4 A DÜSSELDORFI MÜVÉSZAKADÉMIA, AVAGY LUDWIG KNAUS NYOMÁBAN .................................. 104

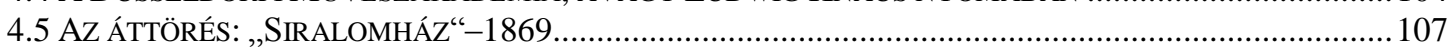




\section{MUNKÁCSY MIHÁLY ÉS A KORABELI MAGYAR FESTŐELIT}

AZ 1873-AS BÉCSI VILÁGKIÁLLÍTÁSON --------------------111

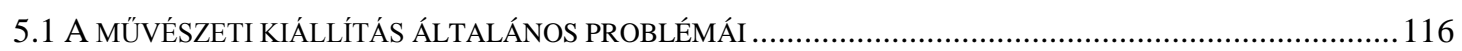

5.1.1 A Müvészeti Csarnok avagy a Kunsthalle felosztása .......................................................... 117

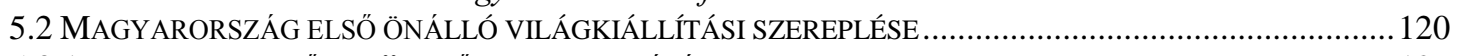

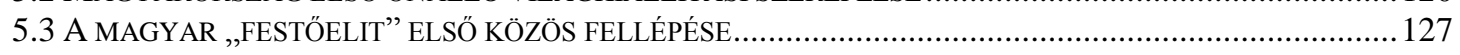

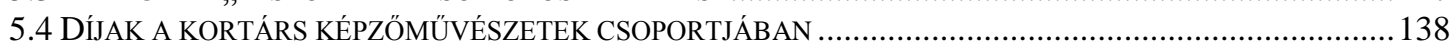

5.5 MUNKÁCSY MIHÁLY MÜVÉSZETÉNEK ELISMERÉSE A FERENC JÓZSEF REND TÜKRÉBEN.................. 143

6. MUNKÁCSY MIHÁLY AVAGY MÜVÉSZI HÍRNÉV ÉS NEMESSÉG

7 A KUNSTHISTORISCHES MUSEUM KUPOLAKÉPE -------------152

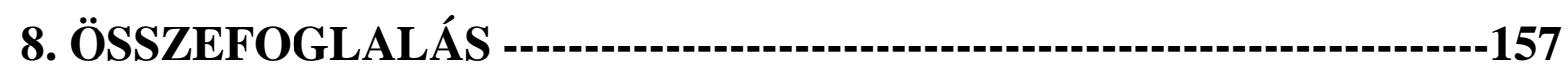

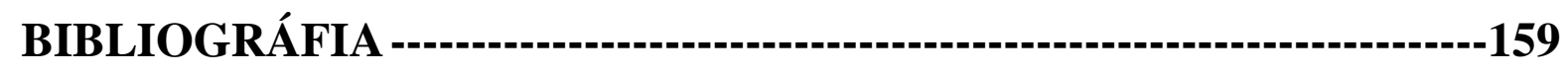

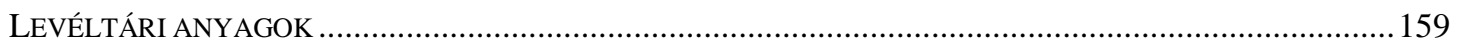

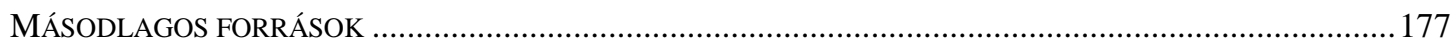

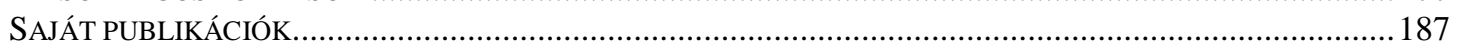




\section{Bevezetés}

A dolgozat az úgynevezett New Art History és a New Cultural History megközelítéseknek megfelelően igyekszik a választott témát megvizsgálni. Munkácsy Mihály pályakezdését a dolgozat a magyar müvészettörténet-írásban érzékelhető paradigmaváltás $^{1}$ szellemében új kontextusba helyezi. A disszertáció párhuzamba állítja Munkácsy Mihály pályakezdését a magyar müvészeti élet kiteljesedésével is. Az új megközelítés szellemében közgazdaságtani és társadalomtörténeti aspektusokból közelítjük meg a kutatott anyagot és a történelmi kontextus fontosságát helyezi a disszertáció fókuszába.

A témaválasztást indokolja, hogy Munkácsy Mihály művészeti pályakezdéséről, azaz első bécsi akadémiai tanulmányairól, az 1864-1865-ben Bécsben töltött időszakáról a Munkácsy irodalomban nem található részletes, ezen időszakot feltáró munka. Mindezt egy alapos, három éves kutatómunka alapozott meg, részben Bécsben (Haus-, Hof- und Staatsarchiv, Wiener Stadt- und Landesarchiv, Wiener Stadt- und Landesbibliothek, Universitätsarchiv der Akademie der bildenden Künste Wien), részben Budapesten (Magyar Nemzeti Galéria, Magyar Országos Levéltár, Magyar Tudományos Akadémia Mủvészettörténeti Kutató Intézete és az Országos Széchényi Könyvtár). Ezen hiányos fejezet pótlását a Munkácsy irodalom kiegészítésén túl az a fontos magyar müvészettörténeti tény is indokolja, hogy Munkácsy Mihály személyében az első világhírnévre szert tett magyar festőművész lépett az európai müvészvilág porondjára.

Személyében az európai, valamint az amerikai müvészvilág elsőként ismerhetett meg egy magyar festőt, akinek müvészetén keresztül a világ tudomást szerezhetett a magyar nemzeti kultúra létezéséről. Müvészete magába ötvözte korábbi mestereinek tanítását, hivatástudatát, munkájuk szeretetét. Munkácsy müvészeti karrierje a maga nemében egyedülálló, hiszen édesapja 1844-ben bekövetkezett halála után egészen 15 éves koráig mint asztalosinas tengette életét. A művészet iránti feleszmélése, majd annak első

\footnotetext{
${ }^{1}$ Lipták Dorottya, Sinkó Katalin, Sármány-Parsons Ilona és Szívós Erika munkáiban is érzékelhetőek a magyar művészettörténet új irányvonalai.
} 
lépcsőfokaira való fellépése Szamossy Eleknek köszönhető. „Self-made-man”-nek nem nevezhetjük, hiszen a müvészet oly magas szintü fokát, amit elért, azt pártfogói és tanítói segítsége nélkül sohasem sikerült volna meghódítani. Szamossy Elek a honvédfestőként is aposztrofált magyar festő a bécsi Karl Rahl által vezetett festőiskolában magába szívott tapasztalatok alapján, amely a régi reneszánsz korok tanítási modelljéig nyúlik vissza, a felszínre segíthette Munkácsy személyében az ún."Naturtalent" kibontakozását. Ez a rahli tanítási módszer helyességének teljes győzelmét jelentette Munkácsy Mihály személyében. A Magyar Mủvészeti Egylet Szamossy ajánlására pedig a pártfogásába vette a fiatal festőnövendéket, majd első mesterén kívül az egykori magyar Rahlianerek ${ }^{2}$, Than Mór és Lotz Károly mint a korszak híres magyar festői biztosították támogatásukról. A Magyar Művészeti Egylet pártolói közösen összefogva első képeit eladását lehetővé téve hozzájárultak ahhoz, hogy a Bécsi Képzőművészeti Akadémiára beiratkozzon és intézményes keretek között folytathassa tanulmányait.

Bécsi tanulmányéve alatt a festészet alapismereteit az Akadémián és Karl Rahl magániskolájában sajátította el. A velencei iskola Rahl által ötvözött aláfestési metódusát itt ismerte meg. A Bécsben kiállított Ludwig Knaus által festett genre képnek köszönhetően (Szemfényvesztő) a német festő vonzáskörébe került. Kedves bécsi professzorának halála után müvészeti útkeresése Knaus nyomán a Müncheni Akadémiára vezette. Követve elhatározását és Knaust, München után Düsseldorfba tette át székhelyét, hogy személyesen a mestertől tanulhasson. A rahli tanítási módszer segítségével felszínre hozott őstehetség az akadémiák szabályai szabta keretek között a saját útját járta, de a megzabolázott és már keretek közé szorított zseni 1870-ben a Párizsi Szalonban kiállított festményével a párizsi kritikusok, valamint művésztársai elismerését is kivívta. Aranyéremmel kitüntetett képe müvészeti hírnevének megalapozását jelentette. Az 1873-as bécsi világkiállításon már a magyar festőelit tagjaként állította ki festményeit.

\footnotetext{
${ }^{2}$ A szerző munkájában szerepel első ízben ez a meghatározás: Polenyák, Ivett (2011), Munkácsy Mihály, avagy művészi hírnév és nemesség, in Antos B., Tamás Á. eds. (2011), Szemelvények ötszáz év magyar történelméböl, Szegedi Tudományegyetem, Szeged.
} 
Európa legnagyobb és legismertebb kiállítótermei nyíltak meg a fiatal magyar müvész művei előtt, amelyek többnyire már a festő mütermében vevőre találtak. Az OsztrákMagyar Monarchia sem vonta ki magát a festő nagyrabecsüléséből. Amit mi sem bizonyít jobban, mint a Munkácsy Mihálynak adományozott magyar nemesség teljesen szokatlan, az adományozási szabályoktól merőben eltérő adományozási módja ${ }^{3}$. Bécsben élete folyamán többször megfordul majd, és 1886-1887-ben egy császári megbízatásnak köszönhetően a Bécsi Képzőmüvészeti Múzeum (Kunsthistorisches Museum) egyik kupolájába festi meg annak egyik mennyezetképét: A Renaissance Apotheozisát.

Jóllehet Munkácsy Mihály életéről már több monográfia íródott, de a bécsi pályakezdő korszakának feldolgozása illetve e korszak a festő jövőjére gyakorolt hatásainak elemzése nélkül. Jelen munka részben ezt a hiányt igyekszik pótolni és felhívni a figyelmet az ezeddig a Munkácsy irodalomban többnyire egy-egy bekezdésre leszükített Karl Rahl bécsi professzor és festő kimagasló jelentőségére Munkácsy művészeti pályafutásában. Rahl hatása nem csak közvetlenül, hanem tanítványai, a magyar Rahlianerek tanításain keresztül, útmutatásuk segítségével nagy mértékben éreztette hatását, akár Rahl tanítási metódusát, akár aláfestési technikáját tekintve, amelyhez Munkácsy Mihály egy életen át hü maradt.

Jelen munka fő célja a Munkácsy irodalom jelentős kiegészítése. A Munkácsy irodalom, illetve több információ helyességének pontos forrásokkal való alátámasztására, helyenként datálására is sor került. Információ hiányában jórészt anekdotákra épülö, tényeknek hitt tévedések tisztázására is törekedtünk. Ezeddig publikálatlan leveleket ismertetetünk és elemzünk.

A disszertacio súlypontja tehát egy mélyreható és összegző müvelődéstörténeti vizsgálat a korabeli források (az osztrák és magyar levéltári iratok, korabeli sajtótermékek, valamint a Munkácsról írott első német nyelvű monográfia) segítségével. Az eddigi Munkácsy monográfiákat áttekintve nem kerülhető meg az a tény, hogy ezek a munkák

\footnotetext{
${ }^{3}$ Polenyák Ivett (2011), Munkácsy Mihály, avagy művészi hírnév és nemesség, in Antos B., Tamás Á. eds. (2011), Szemelvények ötszáz év magyar történelméböl, Szegedi Tudományegyetem, Szeged.
} 
a müvész nagy korszakaira koncentráltak (Düsseldorf, Párizs, Luxembourg). Ezen háttérinformációk tükrében teljesen megalapozott jelen munka azon törekvése, hogy immár a teljesség igényével (a rendelkezésre álló és ezeddig felhasználhatatlan források segítségével) próbáljuk meg áttekinteni a mủvész pályafutása szempontjából mérföldkőnek tekinthető első bécsi évet. Melyek voltak Munkácsy mozgatórugói művészeti pályájának kezdetén? Mi motiválta a fiatal embert? Milyen képeket láthatott Bécs kiállítótermeiben? Kikkel barátkozott? Mely személyek gyakoroltak nagy hatást a kibontakozó tehetségre? Milyen motiváció hatására indult el Münchenbe, majd Düsseldorfba?

A disszertació első fejezete azon kérdésre keresi a választ, hogy Munkácsy Mihály családja milyen anyagi körülmények között élt, azaz családi háttértörténetét taglalja. A festő önéletrajzi könyvének segítségével és édesapja jövedelmének pontos feltérképezésével feltárjuk, hogy a család az akkori viszonyokat figyelembe véve valóban jó körülmények között élt. Majd ennek alapján, tekintve a 19. századi magyar társadalmi rétegeket, a családot besoroljuk a társadalmi hierarchiában. A relatív jólétnek az apa halála utáni megszünése így valóban elementáris erővel hatott a még gyermek Munkácsyra. Az új élethelyzet a sok nyomorúság mellett pozitívumokat is rejtett magában a festő jövőbeni realista stílusban alkotott festményei témájában is visszavisszaköszönve.

Az 1873-ban megrendezett bécsi világkiállítás alkalmával hazafias érzelmei igazi megmérettetésre kerültek, hiszen a festő élt az alkalom adta lehetőséggel, s munkáit a magyar szekcióban állíttatta ki, érmével nemcsak a magyar éremtáblázatot, hanem egyben az akkori magyar festőelit tagjainak csekély létszámát is gazdagítva. Munkácsy patriotizmusának forrását a festő gyermekkori visszaemlékezéseiben, valamint korai művészeti korszakában és a család hátterén túl a liberális eszméket valló tanítóiban kell keresnünk. Első jelentős tanítója, az egykori negyvennyolcas festőként is emlegetett magyar Rahlianer. Hatással volt rá Szamossy Elek, majd lelkes pesti liberális pártfogója, Ligeti Antal, illetve Than Mór és Lotz Károly.

A Bécsi Akadémiára kerülve Munkácsy Mihálynak beszélnie kellett németuil. A kortársak szerint elég csekély nyelvismerettel rendelkezett. Mindez viszonyítás kérdése, 
hiszen egyértelmű az, hogy egy magyar nemesi családban nevelkedett müvésszel összehasonlítva, akit gyerrmekkora hajnalától anyanyelvü vagy képzett házitanítók segítettek a német nyelv megfelelő szintü elsajátításában is, Munkácsy Mihály nyelvismerete természetesen nem vehette fel a versenyt. Ennek ellenére a dolgozat nem felejtkezik meg a család német eredetéről sem. F. Walter Ilges, Munkácsy egykori rokona és személyes jó barátja, aki a festőről a leghitelesebb monográfiát írta meg. E monográfia és az abban közzétett családi levelezés segítségével tisztázzuk ezt a kérdést. A könyv szövege német gót betűvel íródott, ami a magyar monográfiaírókat akadályozta e forrás felhasználását. Müvében a szerző Munkácsy nyomán a család bajor eredetéről is ír. Ezen tények más bizonyítékokkal együtt (Munkácsy édesanyjának a magyar monográfiákban nem idézett levelei kerültek jelen dolgozatban elemzésre) a festő megfelelő szintü német nyelvtudását tárják elénk. Mindez arra a téves hipotézisre is ráirányítja a figyelmet, ami szerint a festő családjának gyökerei Felső-Magyarországon keresendők.

Munkácsy Mihaly életében a Magyar Művészeti Egyletnek döntő jelentősége volt. Életútja korai szakaszára ezen intézmény léte, illetve egy magyar művészeti akadémia hiánya nyomta rá bélyegét, ami indokoltá tette egy, a magyar művészeti élettel, illetve a Magyar Művészeti Egylet születésével foglalkozó alfejezet megírását. Az alfejezet áttekinti a korabeli, főleg német müvészeti egyletek születését, majd a magyar és a bécsi művészeti egylet megszületésének körülményeit párhuzamba állítva érzékelteti a magyar kulturális viszonyok nagyfokú elmaradottságát. Ezen elmaradás miértjére keresve a választ több érdekes tényre hívjuk fel a figyelmet. Az OesterreichischUngarische Revue egy korabeli cikkében közölt dátum alapján pontosítjuk a Magyar Müvészeti Egylet születésének dátumát, valamint a Magyar Művészeti Egylet részvényadatai segítségével a hazai közönség művészetek irányában táplált érdeklődését szemléltetjük egy diagram segítségével.

A Magyar Müvészeti Egylet mellett Munkácsy Mihály első megrendelői is középpontba kerülnek, akiknek támogató jellegü képvásárlásai a fiatal festő számára létfontosságúak voltak. A disszertáció ebből kiinduló alfejezete ezeknek a vásárlási szokásoknak a vizsgálatával foglalkozik. Melyek voltak a motivációs tényezők? Kiktől vásároltak? Hatással volt-e a Bécs szalonjaiban uralkodó divat a magyar arisztokrácia vásárlási 
szokásaira? Hogyan tekintettek a gyenge lábakon álló, intézményesített müvészeti oktatást nélkülöző magyar müvészekre? A feltörekvő meggazdagodott rétegek követték-e a magyar arisztokrácia többnyire ad hoc művészetpártolását és vásárlási szokásait?

A disszertáció harmadik fejezete Szamossy Elek festőmüvész szerepének méltatására helyezi a súlypontot. Megállapítható, hogy Szamossy Elek személyén keresztül Munkácsy a kor egyik legkorszerübb, Karl Rahl által is közvetített tanítási metódusában részesült, amit Szamossy még Rahl ateliéjében szívott magába. Munkácsy első mestere leszámítva a Rahl mesternél töltött tanulmányait egész életében megmaradt autodidaktának, így az általa közvetített tanítási módszer Munkácsy Szamossy mester tanítási óráira való visszaemlékezéseinek tanúbizonysága szerint is a rahli útmutatást követte. Ez a metódus, áttekintve a Bécsi Akadémia történetét, az intézmény által is hivatalosan elismert tanítási módszerré lépett elő. A realizmus későbbi nagy magyar festője hírnevének csúcspontján tudatában lévén öreg mestere munkája fontosságának, 1882. február 21-én a következőképpen fejezte ki köszönetét: „Szamossy korábban felismerte tehetségemet, mint saját magam, így neki köszönhetem azt, akivé lettem.“4 Az egykori Rahlianer segítségén keresztül a bécsi tapasztalatok első hullámainak vetületei így már Munkácsy korai pályakezdő szakaszában is jelen voltak.

Karl Rahl szerepének fontossága a magyar festőmüvészet történetében nem hagyható figyelmen kivül, hiszen a kor magyar festőelitjének egy jelentős része alapozta meg tudását annak bécsi magániskolájában. Rahl aláfestési módszerével szintén Szamossy ateliéjében ismerkedett meg, amiről önéletrajzi írásában is beszámol. F. Walter Ilges munkája tovább pontosítja ezt a kijelentést. Rahl tanitványainak további érdeme, hogy az ő közremuködésükkel honosodhatott meg a monumentális magyar falképfestészet, illetve rájuk is jelentős mértékben alapozva teremtődött meg a hazai magasabb színvonalú festőmüvészet. A bécsi világkiállításon kitüntetett festők csoportjában megtalálhatók Rahl legkiemelkedőbb egykori magyar tanítványainak munkái, így

\footnotetext{
${ }^{4}$ Ilges, F. Walter (1899), M. Von Munkacsy. 27.o. „Szamossy, der mein Talent früher erkannte, als ich selbst, ihm verdanke ich, was ich geworden bin!"
} 
Munkácsy Mihály festményei is, amelyeknek is köszönhetően a magyar éremtáblázat tovább gazdagodott.

A Bécsi Képzőmüvészeti Akadémián folytatott kutatómunka során az is kiderült, hogy Munkácsy sohasem volt az Akadémián Karl Rahl tanítványa, ahogy ez a Munkácsy monográfiákban olvasható. Valójában az Akadémia előkészítő osztályának (Vorbereitungsschule) volt a hallgatója. Az eddig elfogadott nézetnek ellentmondva az akadémiai beiratkozási papirokban az olvasható, hogy az előkészítő osztályban Carl Wurzinger professzor oktatásában részesült. Tehát sem Joseph von Führichnek, sem Theodor Franz Zimmermann-nak nem volt a tanítványa, ahogy ezt a szakirodalom állítja. Rahl professzorral pedig annak magániskolájában került szorosabb kapcsolatba, amiről August Georg Mayer, egykori Rahlianer visszaemlékezése alapján derült ki. Munkácsy ugyanis azon diákok között szerepelt, akik halott professzoruk koporsóját vitték utolsó útjára 1865-ben. E megtiszteltetésben csak Rahl legkedvesebb tanítványai részesülhettek. Ezalapján egyértelművé válik, hogy valóban szoros ismeretségben állt a mesterrel és valóban Karl Rahl magániskolájában tanult.

Bécsben töltött első akadémiai éve alatt Munkácsy Mihály életének egyik legboldogabb időszakat töltötte, amelyről szívesen nosztalgiázik jelen munkában idézett leveleiben, ellentmondva ezzel annak az állításnak, mely szerint a fiatal müvész keserüen tengette napjait a császárvárosban. Unokahúgaihoz íródott levelei szöges ellentétben állnak ezzel a álítással. A valóság az, hogy Munkácsy gazdag barátainak köszönhetően Bécs 1865-ös farsangjának báli szezonját végigmulatta.

A Bécsi Képzőművészeti Akadémiáról való távozásának oka pedig nem a pénztelenség volt, ahogy ezt a Munkacsy irodalom állítja. Munkácsy Mihály bécsi akadémiai papirjaiban ugyanis az olvasható, hogy beiratkozott az aktuális félévre, de 1865. július 17-én törölték az akadémiai tanulók névsorából. További pontosítást jelentenek még azok a Ligeti Antalhoz íródott levelek, amelyek analizálása után egyértelműen kiderül, hogy a festő Ludwig Knaus egy kiállított, Szemfényvesztő (Gaukler) címü festményét látva és eképpen Knaus hatása alá kerülve semmiképpen nem akart a Bécsi Képzőművészeti Akadémián maradni. 
Karl Rahl halála után pedig senki nem marasztalhatta tovább. Ligetihez íródott leveleiben kiderül többek között, hogy Munkácsy ajanlólevelet kért Knaushoz, de miután a német festő Münchent elhagyja, az erről értesülő Munkácsy csak hosszas rábeszélés után szánta rá magát tanulmányainak a Müncheni Akadémián való folytatására. Továbbra sem tett le a Knaus mellett való tanulás szándékáról, ami Düsseldorfba való utazásának mozgatórugója volt. Tehát Ludwig Knaus szerepe Munkácsy leveleinek elemzése nyomán hangsúlyosabb, döntőbb jelentőséggel bír a fiatal müvész pályaépítő éveiben, mint az feltételezhető volt. A dolgozat utolsó fejezete Munkácsy Mihály és a bécsi császári udvar kapcsolatát világítja meg, fókuszba állítva azon kitüntetéseket, amelyekkel a fiatal magyar művész munkáját honorálták. Ezzel is emléket állítva annak Bécsben töltött rövid, ám meghatározó időszakának. 


\section{Munkácsy Mihály családi háttere}

\subsection{Munkácsy Mihály családja az 1820 - 1840-es évek között}

Munkácsy Mihály, anyakönyve szerint Lieb Mihály Leó ${ }^{5}$, német nyelvű, polgári családba született. Születésekor (1844) édesapja (Lieb Mihály) Miskolc városában dolgozott sóhivatalnokként. ${ }^{6}$ A család az apa munkája következtében gyakran váltogatta a lakhelyét, amit az alábbi térkép szemléltet.

\section{1.ábra. Lieb Mihály munkahelyének állomásai 1815 és 1848 között}

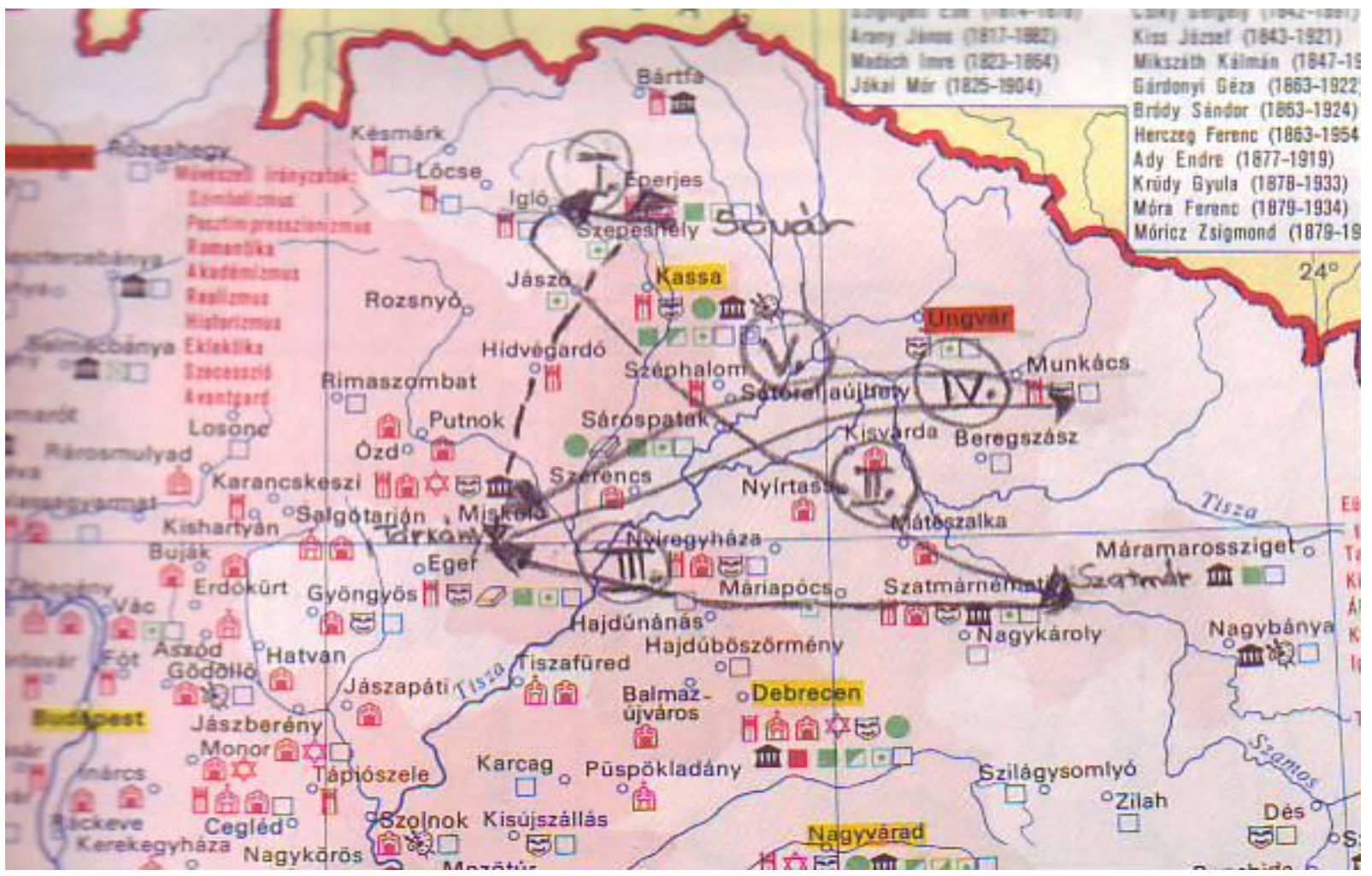

${ }^{5}$ Munkácsy Mihály keresztlevele szerint Lieb Michael Leo. Helytelenül közli: Bakó Zsuzsanna (2012), Munkácsy, Magic \& Mystery. 8.o.

${ }^{6}$ A sómonopóliumról, sóregáléról lásd bővebben: Bán Péter (1989), Magyar Történelmi Fogalomtár, 154.o. 
Forrás: Magyar Történelmi Atlasz (1984), Kartográfiai Vállalat. Budapest.

Munkácsy Mihály családjának életszínvonala szorosan összekapcsolódott az apa sóhivatalbeli szakmai elismerésével. Az apa sóhivatalbeli munkája 1815. Március 11-én vette kezdetét. Munkácsy Mihály nagyapjának hüséges szolgálati elismerésekéntaki egykor sóhivatalnoki posztot töltött be Sóvárra kerülhetett gyakornoknak. ${ }^{7}$ A fizetése évente 90 forint volt, amihez 3 öl fa, 75 font só és ingyenesen biztosított szolgálati lakás tartozott. $^{8}$

Munkája elismeréseként 1821-ben a sóhivatalbeli hierarchia legalsó posztjára emelték gyakornoki posztjáról, így mint felvigyázó dolgozott tovább. Állandó jövedelme már lehetővé tette, hogy családot alapítson. 1821. szeptember 4-én feleségül vette a polgári családból származó Jelinek Annát. ${ }^{9}$ 1823. február 23-án a sóvári sóhivatal írnokává léptették elö. Fizetése 144 forintot, 4 öl fát, 125 font sójövedelemet és ingyenes lakhatást biztosított családjának. ${ }^{10}$ 1829-ben az iglói sóhivatalban már mázsálóként tartják számon. ${ }^{11}$ Három évvel később, 1832-ben Szatmárra rendelik, ahol mázsáló mesteri posztot töltött be. ${ }^{12}$

\footnotetext{
${ }^{7}$ Czeglédi (1975), 254. o./21.-OL. Salinaria 7375/1815.: „Kinevezés Lieb Mihály részére. Nevezettnek a sóvári sóföhivatal javaslatára és édesapja hüséges szolgálatait az említett föhivatalnál figyelembe véve, a megkérelmezett fizetés nélküli gyakorlatát megengedték, és ezt azzal a kiegészítéssel tudatja vele, hogy szolgálati esküje letétele és a titkos egyesülések miatt elöírt (Revers) kiállítása után minden szolgálatával tegye hasznossá magát, és a késöbbi ajánlás céljából tegyen tanúságot a szükséges gyártási ismeretek megszerzéséröl, valamint szolgálatkészségéröl is nyújtson látható bizonyítékot, és nyerje el fölötteseinek megelégedését."

${ }^{8}$ Czeglédi Imre (1975), 254.o /22.-OL. Salinaria. 14063, 17436, 33513/1821.

${ }^{9}$ Czeglédi (1975), 254.o. /22.-OL. Salinaria. 14063, 17436, 33513/1821.

${ }^{10}$ Uo. OL. Salinaria 254.o./4396/1823.

${ }^{11}$ Uo. 255.o. / 30.-OL. Salinaria. 41310/ 1829

${ }^{12}$ Uo. 255.o. / 33.-OL. Salinaria. 14420/ 1832
} 
1834. január 22-én Tárkányba helyezi a hivatal. Itt már mázsálómesteri ellenőrként dolgozott. Fizetése 350 forint volt, amihez 220 font sójövedelem és ingyenes lakhatás járult. $^{13}$

Ha Munkácsy édesapjának a fizetését a megadott adatok alapján összehasonlítjuk az akkori sóbeszedő tárkányi fizetésével, (500 forint és 250 font sójövedelmet, valamint a hivatal által biztosított ingyenes lakhatást jelentett), akkor Munkácsy édesapjának jövedelme semmiképpen sem nevezhető alacsonynak. Igaz, hogy ezen hivatal elfoglalásakor nem csak a szokásos szolgálati esküt kellett letennie, hanem kaucióként egész éves jövedelmét is letétbe kellett helyeznie. 1835-ben az eperjesi sóhivatalban már ellenőrként dolgozott. Hivatali előléptetését egyedül felesége halála árnyékolta be 1835. október 19-én. ${ }^{14}$

1837-ben, Munkácsra áttelepedve, fizetése 400 forintot és175 font só jövedelmet tett ki. ${ }^{15}$ 1838-ban Ungvárra irányították, ahol a sóhivatalban elérhető legmagasabb tisztségre emelték: sóbeszedő lett. A fizetése nem emelkedett forintban (400 Ft.), de a sójövedelmének nagysága 200 fontot tett ki. ${ }^{16}$ 1839-ben újra megházasodott (a házassági anyakönyvi kivonat nem fellelhető.) Reök Ceciliát, Munkácsy Mihály édesanyját, vette feleségül. A család három évet töltött Ungváron. 1841-ben a hivatal újra Munkácsra rendeli, ahol a fizetése 100 forinttal emelkedett. Hét évig laktak a városban. ${ }^{17}$

1848 őszén Miskolcra rendelik. A fizetése ekkor már 600 forint volt, amelyhez a korábbi sójövedelem és a megszokott juttatások járultak. ${ }^{18}$ Lieb Mihálynak huszonhárom évébe került, hogy a sóhivatalban elérhető legmagasabb pozícióba kerüljön. Jövedelmének ezzel párhuzamban való emelkedését a 2. ábra szemlélteti.

\footnotetext{
${ }^{13}$ Uo. 255. o. / 34.-OL. Salinaria. 4011/ 1834.

${ }^{14}$ Uo. 255.o. / 35.-OL. Salinaria. 36182/ 1835

${ }^{15}$ Uo. 255-256. o. / 37.-OL. Salinaria. 12234, 18897/1837

${ }^{16}$ Uo. 256.o. /38.-OL. Salinaria. 37144, 40871/ 1838

${ }^{17}$ Uo. 256.o.-/40. -OL. Salinaria 31689, 43447/ 1841

${ }^{18}$ Uo. 258.o. OL H szekcio 1848-i pénzügyminiszériumi iratok. H 24. 23261/1848. Lieb Mihály.
} 
Munkácsy Mihály édesapjának fizetése a szakmájában eltöltött évekkel egyenes arányban nőtt.

\section{2. ábra Lieb Mihály só kamarai hivatalnok jövedelme 1815 és 1848 között}

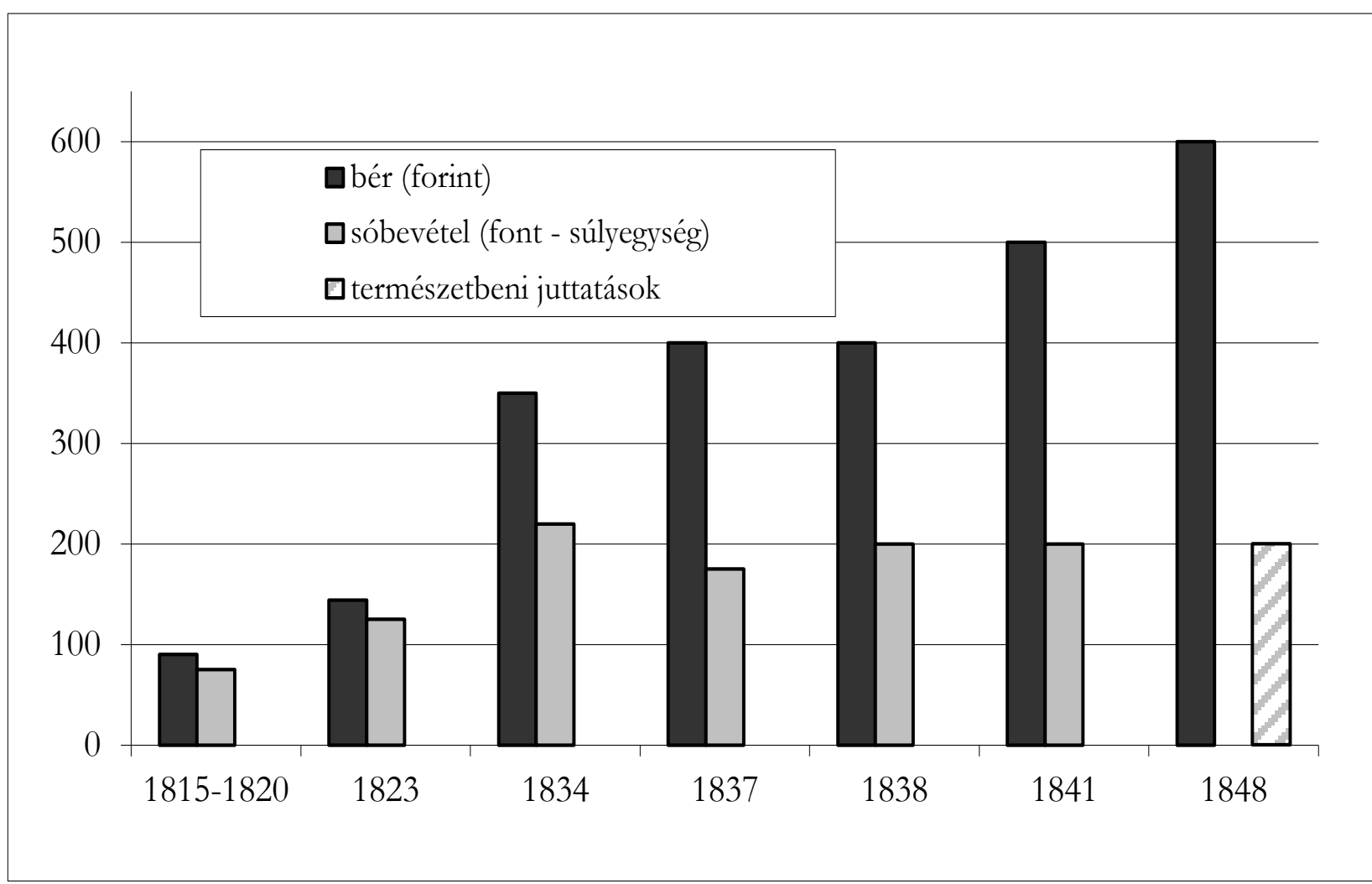

Forrás: Czeglédi Imre (1975), 258.o. A diagramm összeállítása Lieb Mihály 11 szakaszra bontható szakmai életútja alapján készült.

Jövedelmének alakulása alapján megállapítható, hogy családja számára relatív jólétet tudott biztosítani. Helytelen az az állítás, hogy a család vagyontalan és szegény volt. ${ }^{19}$ 1844-ben mindez (Munkácsy Mihály születése körül) csaknem elérhette az 1848-ban kapott bevétel nagyságát. Ha ehhez még hozzáadjuk a Munkácsy által kérelmezett trafik utáni örökségrészt, vagyis az ekkor még a trafikból származtatható hasznot, akkor érzékelhetővé válik a korabeli polgári család életszínvonala. Bizonyítékként

\footnotetext{
${ }^{19}$ Farkas Zoltán (1941), Munkácsy Mihály, 23., 36.o., Zádor Anna ed. (1962), Magyar Müvészet 18001945, In.: Végvári Lajos (1983), Munkácsy Mihály, 219.o., Farkas Zoltán (1943), Munkácsy Mihály, 6.o., Végvári Lajos (1958), Munkácsy Mihály élete és művei, Végvári Lajos (1955), Munkácsy Mihály.
} 
szerepeltethető továbbá Munkácsy visszaemlékezéseiben ${ }^{20}$ található kijelentései, melyek egy jómódú polgárcsalád képét tárják elénk. ${ }^{21,22,23,24}$

A festő visszaemlékezéseit a Munkácsy irodalom nagyvonalúan kezelte, hiszen még a téma híres kutatója, Végváry Lajos is az eredeti visszaemlékezés ide vágó részletét nem szó szerint, hanem leegyszerüsítve adja közre. ${ }^{25}$ Munkácsy visszaemlékezéseiből

\footnotetext{
${ }^{20}$ Michael von Munkácsy (1897), Erinnerungen. Die Kindheit. Mit einem Vorwort von Boyer d'Agen, Autorisierte Übersetzung aus dem Französischen von F. Walter Ilges. F. Fontane \& Co., Berlin. Munkácsy, Mihály (1897), Souvenirs: L’enfance, préface par Boyer D`Agen, Callman Lévy, Paris.Munkácsy Mihály (1950), Emlékeim. Hungária, Budapest.

${ }^{21}$ Munkácsy Mihály (1950), Emlékeim. Hungária, Budapest. 20. o.: „Szenvedélyesen vágytam egy pipa után: szép, kiszívott pipa volt, apám monogrammjával. Ott állt az állványon, ahol apám-akinek ez volt a kedvtelése - a többi különböző nagyságú és formájú pipát tartotta. Úgy voltak rendbe rakva, mint az orgonasípok: elöl a rövidszárúak, körülbelül 25 centiméter hosszúságban, aztán a nagyok, nagyobbak egész két méterig. [...] a szép, formás tajtékpipa [...] színe, mint a tejeskávé. A széle barnúlni kezdett: micsoda színpompa! Vajjon nem ez ébresztette fel bennem először a müvészt?““

${ }^{22}$ Munkácsy (1950), 22.o.:,,Apám szobájában [...] nagyon szép metszet lógott a falon, egy lovagot ábrázolt.“

${ }^{23}$ Munkácsy (1950), 23.o.:,,Szegény apámnak az volt a célja, hogy komoly nevelést adjon valamennyiünknek. Sajnos ezt a munkát nem tudta befejezni.“

${ }^{24}$ Munkácsy (1950), 24.o.:,,A parasztház egyszerüsége nagyon nyugtalanított. Mindent gyorsan szemügyre vettem s bekerültem nagybátyám dolgozószobájába [...]. Ó! Micsoda öröm pompára való éhségemnek! Hiszen én a gazdagságot kerestem! Mint oázis a sivatagban, olyan üdítően csillogott felém egy gyönyörü levélnyomó. Végre megynugodtam, mégsem vagyunk nagyon szegények. A levélnyomó biztosan drága, értékes darab. Hízelgett a hiuságomnak és a büszkeségemnek! Bevallom nagyon boldog voltam, hogy nagybátyámnak ilyen kincse van és kezdtem kibékülni a sorsommal.“

${ }^{25}$ Végvári Lajos (1983), Munkácsy Mihály 1844-1900. Képzőmúvészeti Kiadó, Budapest. 10.o.: „Hat éves lehettem, emlékszem arra a leküzdhetetlen vágyra, hogy egy nagy pipám legyen, kissé kiszívott, mely atyám nevének kezdőbetüivel szobájában egy állványra volt helyezve... szenvedelmesen vágytam erre a tajtékpipára, tejeskávé színe volt, pereme barnulni kezdett, milyen gyönyörü színe volt! Nem volt e vajon ez az első benyomásom, amely felébresztette bennem művészi érzékemet, mert nem azért kívántam meg, hogy szívjam, nem voltam dohányos, tehát formája és színe csábított el, és valóban felismerek ebben két dolgot, mely legjobban kifejeződött bennem, a színesség megérzését és a kerekdedség kedvelését... Nem voltam csodagyerek, aki hatéves korában már remekmúveket alkot. Firkálgattam, ha meg tudtam kaparintani egy ceruzát."
} 
kiderül többek között, hogy a gyerekeknek valóban a polgári szinthez megfelelő neveltetésben volt részük. Ennek keretében a magyar mellett a francia nyelvre is hangsúlyt fektettek. ${ }^{26}$ Munkácsy sógora, Zsilinszky Mihály a „Magyar Szalon“ hasábjain cikksorozatot jelentetett meg a festő életéröl. ${ }^{27}$ Érdekes adalékként említi meg, hogy a Lieb-ház az „,intelligens“ emberek összejöveteleinek központja volt. ${ }^{28} \mathrm{Az}$ édesanyát pedig szellemes háziasszonyként írja le, akinek „előkelő modora a franczia salonokra emlékeztet.“29 A szerző kiemeli, hogy Munkácsy édesanyja gyermekei nevelésére nagy gondot fordított: „Segítségül tartott maga mellett nyelvmestereket és nevelönőt. “30

\subsection{Az 1848-as forradalom szerepe a Lieb család életében}

A sóhivatalbeli tisztség betöltésének mindenkori feltétele volt a fennálló hatalom iránti megkérdőjelezhetetlen hüség. Lieb Mihály lojalitását az 1848 márciusi események iránti rokonszenv kérdőjelezhette meg. A forradalom ugyanis megteremtette a nemzetiségek számára azt a lehetőséget, hogy a magyarokkal sorsközösséget formáljanak. Maga Munkácsy Mihály a visszaemlékezéseiben is méltatja apjának a forradalommal való rokonszenvét, melynek köszönhetően fogságba került. ${ }^{31}$

\footnotetext{
${ }^{26}$ Munkácsy (1897), 6.o.

${ }^{27}$ Magyar Salon (1886), V. kötet, 6. szám. ed.:Fekete József, Hevesi József. Zsilinszky Mihály: Munkácsy Gyerekkorából.

${ }^{28}$ Magyar Salon (1886), V. kötet, 6. szám. 259.o.

${ }^{29}$ Magyar Salon (1886), V. kötet, 6. szám. 259.o.

${ }^{30}$ Magyar Salon (1886), V. kötet, 6. szám. 260.o.

${ }^{31}$ Munkácsy (1950), 18.o. „Az országban vér folyt és szegény apám is sokat szenvedett: polgári kötelessége visszatartotta Miskolcon és nagyon nyugtalanította családja sorsa, amely nem érezhette magát biztonságban. [...] Apámat Miskolcon elfogta az ellenség, börtönbe került és a fogságban megbetegedett.“
} 
1848. május 12-én Lieb Mihály tagja lett a forradalom alatt megalakított Közrend Bizottságnak. Naponta vett részt ennek ülésein. Ezen forradalmi szereplése miatt Kufstein börtönében is raboskodott. ${ }^{32}$ Miután kiszabadult, állását is elveszítette, ami a család életszínvonalának csökkenéséhez vezetett. A szabadulása után szerette volna az erkölcsi és politikai magatartását tisztázni, melyről az alábbi 1849-ből származó Munkács városában kelt jegyzőkönyv is tanúskodik. ${ }^{33}$

E szerint: „Mi ezen kérelemnek engedve ezennel bizonyítjuk, hogy mi T. Lieb Mihály urat, ki mint kamarai só pénztárnok több évekig lakott városunkban oly egyénnek ismertük, kinek politikai egész életét hivatalos szigoru eljárás s szeplőtlen erkölcsü jellem bélyegezvén a közelebb tartott forradalmi viszonyokban nem csak, hogy soha legkisebb részt nem vett, söt minden maga viseletéből az uralkodó ház, a felséges cs. és király iránti tántoríthatatlan mély tisztelet és jobbágyi hüség látszatott szembe tünöleg tündökleni.“ Az apa még-e tanúsítványnak köszönhetően sem nyerte vissza a hivatal bizalmát és hivatalnokként nem tudott alkalmazást nyerni.

\footnotetext{
${ }^{32}$ Sas Andor (1927), Szabadalmas Munkács levéltára. 98-101.o.

${ }^{33}$ Sas (1927), 98-101.o. „1849.-ki szept. 27.-én Gáthy Sámuel föbíró, Láng Vitus jelenlétükben tartott tanácsülésben:
}

13. / Lieb Mihály jelenlegi miskolczi lakos, kamarai só pénztárnok eziránt keresvén meg személyesen a Tanácsot, „ hogy részére itt lakta alatt tanusított politikai életéről s erkölcsi magaviseletéröl hiteles alakbani bizonyíték adatnék.

14./ A jegyző jelentvén, hogy a fenntebbeni bizonyítékot elkészítvén, a tartalma a következő: Mi szabadalmas Munkács város főbírája s tanácsnoki adjuk tudtul, hogy midőn mai napon hatósági dolgaink az városi polgárság ügyei intézkedésével foglalkozánk s rendes városi polgárság ügyei intézkedésével foglalkozánk s rendes tanácsülést tartánk, ugyanakkor személyesen megkeresvén bennünket Tettes Lieb Mihály ur és azon kérelemmel járult hozzánk, hogy itt lakása alatt tanusított politikai életéről s erkölcsi megaviseletéről részére hiteles alakban bizonyítékot adnánk: Mi ezen kérelemnek engedve ezennel bizonyítjuk, hogy mi T. Lieb Mihály urat, ki mint kamarai só pénztárnok több évekig lakott városunkban oly egyénnek ismertük, kinek politikai egész életét hivatalos szigoru eljárás s szeplötlen erkölcsü jellem bélyegezvén a közelebb tartott forradalmi viszonyokban nem csak, hogy soha legkisebb részt nem vett, sőt minden maga viseletéböl az uralkodó ház, a felséges cs. És király iránti tántoríthatatlan mély tisztelet és jobbágyi hüség látszatott szembe tünőleg tündökleni. Stb... Aláírások.“ 
A nemzetiségek a forradalomnak köszönhetően sorsközösséget élhettek át a magyarokkal. ${ }^{34} \mathrm{Az}$ asszimiláció szép példájául szolgál Lieb Mihály családja is. ${ }^{35} \mathrm{~A}$ beilleszkedés feltétele elsősorban a magyar nyelv elsajátítása volt. Gyermekei taníttatására az apa nagy hangsúlyt fektetett. ${ }^{36}$ Ugyanakkor a magyar nyelv mellett a franciát is fontosnak tartotta. Munkácsy visszaemlékezései az apa gyermekei nevelésének irányában mutatott elhivatottságát tükrözik vissza. ${ }^{37,38}$

A Munkácsy irodalom gerincét képező Végvári Lajos ${ }^{39}$ által írt művek arról győzik meg az olvasót, hogy a később híressé vált festő gyermekkorában kizárólag magyarul beszélt és értett.Ennek alátámasztására közli, hogy az asszimilációnak köszönhetően nem volt jelentősége annak, hogy német eredetű volt a családja. Munkácsy visszaemlékezései és a Magyar Nemzeti Galériában örzött német és francia nyelven íródott levelek ennek ellenkezőjéről tesznek tanúbizonyságot.

A festő német nyelvtudásával összefüggő további bizonyíték Ligeti Antallal való levelezése, amelyben a bécsi akadémiai tanulmányainak előkészítéséről szóló részeiben egyszer sem merül fel a német nyelv problémája. Mindezt tovább erösíti az a tény, hogy a Bécsi Képzőművészeti Akadémiára való beiratkozási papírok alapján, a beiratkozáshoz szükséges 2 gimnáziumi osztályáról tanúskodó bizonyítvány szerint Munkácsy igenis beszét és értett németül. Gimnáziumi szintű tudást csak családi körben tudott elsajátítani, mivel nem járhatott iskolába édesapja korán bekövetkezett halála miatt. A gyerekek további nevelését az anya látta el, aki anyanyelvét tekintve német polgári családból származott.

\footnotetext{
${ }^{34}$ Pukánszky Béla (2000), Német Polgárság Magyar Földön. Kissebbségkutatás Könyvek. 32.o.

${ }^{35}$ Pukánszky Béla (2006), Pukánszky több hasonló utat bejárt német ajkú családot ismertet.

${ }^{36}$ A gyerekek nevelésére egy nevelő és egy pesztonka ügyelt.

${ }^{37}$ Munkácsy (1897), 6.o. : ,[...] Szerencsére éppen ekkor lépett ki az udvarra a francia tanárunk.”

${ }^{38}$ Munkácsy (1897), 7.o.: „Nevelőnk a házban lakott és egy pillanatra sem tévesztett bennünket szem elöl.“

${ }^{39}$ Végvári Lajos (1958), Munkácsy Mihály élete és müvei.
} 
A család német nyelvi szintjéről tanúskodik továbbá az az $\mathrm{F}$. Walter Ilges monográfiájának köszönhetően fennmaradt, Reök Cecíliától, a festő édesanyjától származó levél, melyet 1848. február 6-án írt sógornőjének, Reök Júliának. ${ }^{40}$ A levél hibátlan irodalmi németséggel íródott. Tartalmát tekintve egy művelt és gyermekszerető anya képe bontakozik ki az olvasó előtt, aki sok kedvességgel és szeretettel ír családjáról. ${ }^{41}$ Az anya leveléből továbbá az is napvilágra kerül, hogy Lieb Mihály hiába pályázott a pesti sóhivatal kontrollnoki állására. ${ }^{42}$

Édesanyja, ${ }^{43}$ majd édesapja halála ${ }^{44}$ után Munkácsy Mihály nevelését anyai nagybátyja, Reök István ${ }^{45}$ látta el. Az elszegényedett, de foglalkozását tekintve ügyvéd a szabadságharc idején betöltött titkári funkciója ${ }^{46}$ miatt eredeti hivatását nem folytathatta. Foglalkozása miatt a német nyelv precíz tudása elengedhetetlen volt. ${ }^{47} \mathrm{~A}$ fiú így családi körben is megtanulhatott németül.

\subsection{Munkácsy Mihály családja eredetének újabb lehetséges magyarázata}

\footnotetext{
${ }^{40}$ F. Walter Ilges (1899), M. von Munkacsy. 11-12.o.

${ }^{41} \mathrm{~F}$. Walter Ilges (1899), 12.o.

${ }^{42}$ F. Walter Ilges (1899), 12.o.: ,[...] mein Misi ist um die Pester Kontrollerstelle eingekommen, es ist aber auch das schon vereitelt, so wie uns überhaupt das Glück wenig hold ist.“

${ }^{43}$ Reök Cecília, 1850.január 12.én halt meg.

${ }^{44}$ Lieb Mihály( 1800 -1852)

${ }^{45}$ Reök István (1816-1877)

${ }^{46}$ Ceglédi Imre (1975), Munkácsy Békéscsabán. 1848 májusától Klauzál Gábor kereskedelemügyi miniszter titkára volt. In.: Polner Lajos jelentése a BML Békéscsabai föszolgabírói iratok I/1853. sz.

${ }^{47}$ Ceglédi Imre (1975), Munkácsy Békéscsabán. In.: Polner Lajos jelentése a BML Békéscsabai föszolgabírói iratok I/1853. sz. alatt szerepel.: „Müveltsége pedig és képzettsége minden tekintetben kitünő, beszélli a magyar országi szokásban lévő 4 nyelveket s francziául is ért.”
} 
Munkácsy Mihály családjának eredete a Munkácsy kutatók számára máig az egyik legvitatottabb kérdéskörbe tartozik. Ez az irodalmat áttekintve a következő konklúzió vonható le: az írók a festő családjának atyai és anyai ágát vizsgálva egyetértenek abban, hogy mindkettő német eredetü. Lyka Károly szerint a család már a 18. században, pontosabban 1731-ben a Királyi Magyarország területén élt és nagymértékben asszimilálódott, amit az apa 1848-as magatartása is alátámaszt. ${ }^{48}$ A vitás kérdés alapvetően abból adódik, hogy a család Európa mely német nyelvü területéről származhat. Néhány író tudni véli, hogy a Lieb família bajor földről eredeteztethető, ezt képviseli például Székely András ${ }^{49}$ vagy Ónodi Magdolna. ${ }^{50}$

Ónodi Magdolna szerint Munkácsy édesapja felmenői a 18. században költöztek a Felvidékre, amit azzal bizonyít, hogy a Felvidéken fellelhető Lieb család több tagja valamely müvészeti ágban tehetséget tudott felmutatni. „A Munkácsy őseinek a családi följegyzéseit tartalmazó kódex, amely a bártfai városház levéltárából maradt ránk, annyival is inkább érdekes, mert fölvilágosít arról, mint származott át a mester családja külföldről hazánkba, s olyan adatokat is tartalmaz, amelyek arra vetnek fényt, hogy a Lieb családban nem Munkácsyban nyilvánult először a művészet iránt való hajlandóság."

Az állítás gyenge pontja azonban az az alapvető tény, hogy a családfa Munkácsy családjával kapcsolatba hozott ága hiányos. Maga az író is lejegyzi, hogy Munkácsy Mihály édesapjának a megnevezett felvidéki Lieb családhoz köthető anyakönyvi adata nem lelhető fel: „Ugyanez a Lieb 1779-ben a bártfai plébánostól bizonyítványt kap, hogy felesége a Sáros megyei Frieska nevü faluban halt meg, ahol a görög katolikus pap temette el, s így ismét szabadon nősült, de csak később, mert ennek az 1785-ben az öreg Lieb hagyatékából a bártfai városház levéltárába került kódexben nincs nyoma. Ha volt is több fia, minden valószínüség szerint György János József, a Bliha Mária Annától

\footnotetext{
${ }^{48}$ Lyka Károly (1964), 6.o.

${ }^{49}$ Székely András (1979), 7.o.

${ }^{50}$ Bakó, Kürti és Ónody Magdolna (2005), Munkácsy, 16.o.: „Der erste Lieb, János Károly Ferenc war 1639 Stiftsekretär des bayerischen Kurfürsten [...]“

${ }^{51}$ Bakó, Kürti és Ónody (2005), 15.o.
} 
1770-ben született fiú volt Lieb Leó Mihály apja, aki, dédapjához hasonlóan, kincstári sótiszt volt. [...] Lieb Leó Mihály szüleinek a nevét az okmány nem tartalmazza, de a bártfai hagyományon kívül az a körülmény is valószínűvé teszi a bártfai családjával való kapcsolatát, hogy írója és Munkácsy apja, valamint minden valószínűség szerint nagyapja is egyazon hivatalt viselte." 52

Az Ónody tanulmány Czeglédi munkáját is megpróbálja felhasználni hipotézisének alátámasztásához, de ez is eredménytelen. Czeglédi Imre ugyanis munkáját a következő beismeréssel zárja: „A tanulmányban Lieb Imrénél közölt bánáti sóhivatalnokot csak a név-és foglalkozásazonosság alapján ,azonosítottam“ a Lieb családdal, s nem anyakönyvek alapján, így a személy azonossága csak feltételezett. “53 Czeglédi Imre kutatásait lektora Széphelyi F. György nagyra méltatja, de az író munkáját nem tartja közlésre érdemesnek, mivel az eredeti célját, azaz a Lieb család Felvidékről való származásának egyértelmü bizonyítását nem érte el. ${ }^{54}$

A magyar kutatók egyáltalán nem vagy csak a közölt képek miatt tesznek említést $\mathrm{F}$. Walter Ilges Munkácsyról írt monográfiájáról. A monográfia értékességét azonban előtérbe helyezi Munkácsynak az íróval folytatott személyes beszélgetései. A festő visszaemlékezései a családi szájhagyományhoz nyúlnak vissza, ami alapján a Lieb család Tirolból származik. Az 1848-as forradalom és szabadságharc alatt tünhettek el az ezt alátámasztó anyakönyvek. A családi tradíció azonban úgy tartotta, hogy a Liebek Tirolból települtek Magyarországra, és eredetileg az ausztriai Lilienfeld településhez köthető a Lieb családnév. “.55

\footnotetext{
${ }^{52}$ Bakó Zsuzsanna, Kürti Katalin és Ónody Magdolna (2005), 17.o.

${ }^{53}$ Czeglédi Imre (1975), 270.o.

${ }^{54}$ Széphelyi (1977), :“ [...] A szerző alapos, gondos levéltári kutatásai minden igyekezet dacára sem tudták a hipotézis helyességét bizonyítani - igaz, végérvényesen sem. [...] Sajnálatos, hogy a negatív eredmény a tanulmány adatait számunkra szükségszerüen partikuláris jelentőségűvé teszi [...]” Magyar Tudományos Akadémia Müvészettörténeti Kutatóintézete MKCS C-I-92/3 (1-2)

${ }^{55}$ Ilges (1899), 10.o. ,[...] Lieb von Lilienfeld geheißen haben. Die Wahrscheinlichkeit einer solchen Einwanderung ist ziemlich groß, (vergl. u. a. Dr. Quitzmann, Reisebriefe, Stuttgart 1850, 51. o. : „Die
} 
F. Walter Ilges hipotézisének megfellebezhetetlen elönye a fentebb megnevezett állításokkal szemben, hogy közléseiben még közvetlenül a festő szóbeli kijelentéseire hivatkozhatott. Művében a nemesi származás kérdésével is foglalkozott. Sziléziában és bajor földön is fellelhető egy-egy nemes Lieb családnév, de Lilienfeld és Szilézia is fel tud mutatni ugyanúgy egy nemes Lieb familiát. A közvetlen származás bizonyítékának hiányában azonban Munkácsy egyik nemesi családhoz való kötődése sem bizonyítható. Mindez egy jövőbeni komoly kutatási munka alapját képezhetné. A Lieb család nemesi címerében található egy ezüst talpas kereszt (Tatzenkreuz), melyet négy ezüst golyó vesz körül fekete mezőben, a sisakon pedig összezárt, jobbra néző szárnyakkal. Mindez egy német polgári származásra feltételezésére adhat okot. A talpas kereszt egyedül az alábbi német családoknál fordul elő: Volz, Friedrich, Baltzer, Kunad, Bodel, Ehrmans, Kerig, ugyanúgy megtalálható az Oberhuser és Hermann polgári családoknál is. A zsidó származást azonban az író teljes mértékben kizárja. ${ }^{56}$

[...] Mégha a családfája a szép Tirolba vezethető is vissza, Munkácsy mind művészetében, mind pedig világnézeteiben igazi magyar volt. ${ }^{657} \mathrm{~A}$ legerősebb és mind a mai napig nem méltatott tény azonban az, hogy maga a festő, Munkácsy Mihály, követve a családi tradíciót, Tirolból eredeztette apai ágát. ${ }^{58}$

westlichen Komitate Ungarns haben überhaupt einen mehr deutschen Charakter. [...] „Aufnahme schwäbischer, österreichischer und steirischer Kolonisten ist die Ursache dieser Erscheinung.“

${ }^{56}$ Ilges (1899), 10-11.o. :So viel ist auf jeden Fall aber sicher, daß auch nicht der kleinste Hinweis auf jüdische Abstammung deutet, kaum der Name denn Lieb kommt in echt deutschen Bürger- und Bauernfamilien schon früh vor, in Heilbronn lebte z. B. zur Zeit des großen Bauernkrieges, also im Anfange des XVI. Jahrhunderts eine Bürgerin Anna Lieb (Vergl. Zimmermann, Geschichte des großen Bauernkrieges, Stuttgart 1856, Bd. II. 19.o.

${ }^{57}$ Ilges (1899), 10-11.o. ,[...] Munkacsy ist selbst, wenn sein Stammbaum ins schöne Land Tirol zurückzuführen sollte, sowohl in seiner Kunst wie in seinen Anschauungen ein echter Ungar.“

${ }^{58}$ Ilges (1899), 10-11.o. 


\section{Eszmélet, avagy a magyar múvészet intézményes kereteinek kialakulása és Munkácsy Mihály pályakezdése}

A magyar müvészet intézményes kereteinek a kialakulása, majd nagy léptekkel való felzárkózása, intenzívvé válása időben egybeesik Munkácsy pályakezdésével. Magyarországon még a 19. század ötvenes és hatvanas éveiben sem teremtődtek meg egy művészeti akadémia megalapításának a feltételei. Bár a Marastoni Jakab ${ }^{59}$ által alapított első magyar festészeti akadémia (1845-1860) megpróbálta a hiányt pótolni, de ez a megfelelő állami támogatás nélkül nem lehetett életképes. ${ }^{60}$

Azoknak a fiatal művészet terén tehetséges fiataloknak, akik elhivatottságot éreztek valamely müvészeti ág iránt, csak külföldi müvészeti tanintézményekben bővíthették ismereteiket. ${ }^{61}$ Akár a legközelebb fekvő Bécsi Művészeti Akadémiára, akár a távolabbi német vagy francia művészeti intézményekre esett a választásuk, óriási hátrányt kellett ledolgozniuk. Az ezidőben már működő magyarországi Pesti Műegyletnek (18391868) ${ }^{62}$ a kiállítási anyagát nagyon behatárolt keretek közül kellett kiválogatnia. Magyar mủvésztől származó nívós anyaggal szinte nem is számolhattak. Kiállításaik a külföldi, elsősorban osztrák, bécsi festők műveinek teremtettek eladási lehetőségeket. A Bécsi Müvészeti Egylet kiállítóinak műveit összehasonlítva a Pesti Mủegylet kiállított anyagával szembetünő a színvonalbeli különbség, hiszen a külföldi kiállító művészek a

\footnotetext{
${ }^{59}$ Marastoni Jakab (1804-1860), Olaszországban tanult festő. Életképei, portréi révén elismert művész. Vezetője és alapítója az első magyar festőakadémiának.In: Zádor Anna ed. (1962), Magyar művészet 1800-1945. 76-77.o.

${ }^{60}$ Rabinovsky Máriusz (1952) A művészeti oktatás kezdetei Magyarországon. In: A Magyar Művészeti Munkaközösség Évkönyve 1951. Budapest, 67.o.

${ }^{61} \mathrm{~A}$ művészeti akadémiákon tovább tanulni vágyók elsősorban a bécsit, a münchenit, düsseldorfi és párizsi akadémiákat keresték fel.

${ }^{62}$ A Pesti Műegyletet 1839-ben alapították. 1868-ban beolvadt az Országos Magyar Képzőmüvészeti Társulatba. In: Zádor Anna ed. (1962), 77.o.
} 
magyar kiállításon nem a legszínvonalasabb munkáikkal képviseltették magukat. A Bécsi Képzőművészeti Akadémiáról kikerült, a korabeli nyugat-európai színvonalnak megfelelő anyagból azonban a Bécsi Müvészeti Egylet tekintélyes kiállítást állíthatott össze.

Munkácsy Mihály művészeti tehetsége pártfogók nélkül nem tudott volna kibontakozni (a festő 1864-ig semmilyen művészeti akadémiai oktatásban nem részesült.). Mint ahogy erős támogatottság hiányában a magyar intézményes müvészeti nevelés is életképtelen maradt volna. A magyar mủvészet lelkes pártfogóinak, mecénásainak ${ }^{63}$ köszönhetően mindkettő gyors és ugrásszerü fejlődésen ment keresztül, ami idővel széles körben éreztette hatását. A magyar kultúra és müvészet felkarolásának ügye a reformkorban került szélesebb társadalmi körben terítékre, erös polgárság híján a felvilágosult arisztokrácia, a nemesség és a nagypolgárság révén. Ezen nemzeti ügynek tekintett támogatás több kulturális intézmény életre hívásában is megnyilvánult. Ennek a felívelő periódusnak az 1848-as forradalom és szabadságharc vetett véget. Így az 1850-es és 1860-as években a fejlődés megtorpant, mert ezek a felvilágosult rétegek, részben a szabadságharcos múltjuknak, részben az abszolutizmus éveinek köszönhetően háttérbe szorultak. Az abszolutizmus dacára a magyar kultúra ápolása hazafias kötelességként élt a magyar társadalom különböző rétegeiben, más és más formában megnyílvánulva. Az adományozni kívánók egy olyan alkalmat teremtettek, ahol a honi művészet felkarolásának ügyében saját elfolytott nemzeti érzéseiknek is teret teremtettek. A magyar kultúra ápolását sokan érezték a kötelességüknek. Mindez megnyilvánult a mecénási szerepkör magukra vállalásában. Nekik köszönhető anyagi támogatás fejében a nem nemesi származású, ám a művészet terén tehetséges ifjak kezdhették meg tanulmányaikat külföldi akadémiákon. ${ }^{64,65,66}$

\footnotetext{
${ }^{63}$ Sinkó Katalin (1981), A Magyar mügyüjtés 1850 után - a magángyüjteményi kiállítások tükrében. In: Válogatás magyar magángyüjteményekből. Kiállitási katalógus. Magyar Nemzeti Galéria. Budapest, 1981. október-november, 11-29.o

${ }^{64}$ Végvári Lajos (1958), Munkácsy Mihály élete és művei.

${ }^{65}$ Végvári (1958), 32.o. Idézi.: Léderer-Farkas Gy., Az asszimiláció a magyar irodalomban. Bp. 1938., 36.o. “[...] Elsősorban a tökések és a velük szövetséges főnemesség egy része-az iparmágnások-a
} 


\subsection{Az első polgári dominanciával formálódott müvészeti egyesületek Európa horizontján}

\subsubsection{Az előfutárok ${ }^{67}$}

Ezen alfejezet arra a fontos problémára ${ }^{68}$ helyezi a hangsúlyt, hogy Európában melyek voltak azok a Pesti Müegylet ${ }^{69}$ megalapításakor már létező és zömmel a polgárság részvételével megalakult müvészeti vagy a mủvelődés terén fontos szerepet játszó egyletek és egyesülések, amelyek befolyásolhatták ennek müködését. Munkácsy Mihály

kiegyezés igazi előkészítői, megtagadják a 48-as eszméket, vagy ha néha felemlítik is, az már csak politikai alku és nem meggyőződés dolga. [...] Ezek a nemzeti érdekektől távolálló osztályok és rétegek lényegében a gyarmatosítás új formáját készítik elö: a kiegyezés - a magyar „függetlenség““ helyreállítása-lényegében nem más, mint olyan helyzet teremtése, amelyben a magyar államiság konjunktúrális lehetőségeit a legkedvezőbben kihasználhatják. Ez az új vezető csoport tehát másképpen gondolkozott a haza sorsáról, mint Reök István és a vidéki kisnemesek. Az áldozatos hazaszeretet helyett a maguk egyéni hasznának minél jobb biztosítása irányította tetteiket. Ez határozta meg a müvelődés dolgaiban, s így a képzőművészet terén is állásfoglalásukat. Már nem vállalnak olyan áldozatokat, mint a reformkor idején“"

${ }^{66}$ Gosztonyi Ferenc (ed) (2005), Munkácsy a nagyvilágban. A tanulmánykötet bibliográfiáját tekintve pedig látható Végváry munkáinak a hangsúlyos volta. 245.o.

${ }^{67}$ Polenyák Ivett (2010), Die Rolle des Mäzenatentums im Spiegel der österreichischen und ungarischen Kunstvereine im 19. Jahrhundert. Die englischen und deutschen Vorläufer.466-468.o. In: Milan Hlavačka, Magdaléna Pokorná and Tomáš W. Pavlíček eds. (2010), Collective and Individual Patronage and the Culture of Public Donation in Civil Society in the 19th and 20th Centuries in Central Europe, Prague.

${ }^{68} \mathrm{Az}$ első művészetpártoló egyesületek Angliában kerültek megalapításra a magyar művészettörténeti szakirodalom Zürich, Nürnberg, Prága és Berlin szerepét hangsúlyozza. Sinkó, Katalin (1995), A művészi siker anatómiája 1840-1900. In: Aranyérmek, ezüstkoszorúk. Müvészkultusz és müpártolás Magyarországon a 19. században. 18.o.

${ }^{69}$ Szvoboda Dománszky Gabriella (2001), A Pesti Müegylet története. Budapesti Negyed, 2001. 2-3. szám. 65-91.o. 
pályakezdése ugyanis szorosan összefonódik a Pesti Műegylet megalapításával, az első fiatal, tehetséges és már a nyugat-európai színvonalnak megfelelő magyar művésznemzedék megjelenésével.

Ezen felvilágosult eszmei áramlásnak az első állomásai Anglia nagyvárosai voltak, elnyerve a városok polgárságának rokonszenvét és támogatását. A megalakult angliai mủvészeti egyesületek tekintélyüket pártfogóik révén is növelték. Kiemelkedő ezek közül a Londonban 1733-ban megalapított „Society of Dilettanti“ egyesület, melynek életre hívása felvilágosult eszméken alapult és nemesi patrónus támogatását élvezte. ${ }^{70}$

A müvészeti egyesületek megalapításában az első úttörő az 1727- ben Birmingham-ben alapított „Society of Arts and Manufactures.“"71 Négy évvel később, 1731-ben a „Royal Dublin Society," majd az 1754-től müködő Society of Arts megjelenése követte. Az angliai alapítások német kezdeményezéseknek nyitottak utat, például a hamburgi „patriotische Gesellschaft zur Beförderung der Künste und nützlichen Gewerbe“ müvészeti egyesületnek (1765). ${ }^{72}$

1787-ben egy zürichi müvészeti, majd négy évvel később egy nürnbergi egyesület a „Verein für Künstler und Kunstfreunde“ kezdte meg a müködését. Az alapítások sorában Prága következett, ahol egy nemesi kezdeményezés keretében került sor egy „exklusive Zusammenschluß der patriotischen Kunstfreunde“ azaz egy Exkluzív

\footnotetext{
${ }^{70}$ Birgit Biedermann (2001), 19.o. Zit.: Nipperdey (1972), Zu dem Verhältnis von Adel und Bürgertum zu den Assoziationen und ihr Zusammentreffen innerhalb dieser Organisationen. : „Die Selbstorganisation der Bürger in Assoziationen und Gesellschaften sollte hier Abhilfe schaffen. Dabei darf keinesfalls davon ausgegangen werden, dass diese Gründungen sich im Sinne revolutionärer Initiativen gegen Landesherren und Regierungen richteten. Ganz den Ideen der Aufklärung verpflichtet, bezogen sie oftmals den Adel mit ein oder sie standen sogar unter fürstlichem Patronat.

Besonders bei den frühen Gründungen waren exklusive Vereinigungen des gehobenen Bürgertums oder des Adels. So z.B. die 1733 gegründete „Society of Dilettanti“ in London, deren Mitglieder bis auf wenige Ausnahmen den Adelhäusern entstammten.“

${ }^{71}$ Gerlach Peter (1994), Vom realen Nutzen idealer Bilder, Kunstmarkt und Kunstvereine. 112.o.

${ }^{72}$ Sinkó Katalin (1995), 18.o.
} 
Patrióta Mübarátok Egyesület létrehozására. ${ }^{73}$ A hamburgi egyesület 1767-től szervezett kiállításokat. A képzőművészek között díjakat sorsoltak ki. ${ }^{74}$ A korai alapítások közül kiemelkedik a londoni (1754) „Society for the Encouragement of Arts, Manufactures and Commerce", ami ugyancsak a belföldi képzőmüvészek támogatására alapított díjakat. Történelmi témában alkotó festőmüvészek, szobrászok, és építészek tervrajzaira, továbbá kiállítások szervezésére adományozták. Ez a brit intézmény volt az első olyan angol műbarátok által létrehozott egyesület, amely kizáróag a hazai, fiatal müvészgenerációt támogatta. ${ }^{75}$

Az első európai müvészeti egyesületeket tehát már a tizennyolcadik században megalapították és nem a tizenkilencedik századhoz kötődnek, ahogy ez a magyar szakirodalomban olvasható. ${ }^{76}$ A Pesti Múegylet megalapításában azok a közép-európai mủvészegyletek domináltak, amelyek a földrajzi közelségük miatt ennek szomszédságában voltak. Ezek külföldi kapcsolataik révén távolabbi müvészeti egyesületek müködését, illetve az ezek fennállását szavatoló tapasztalatokat is közvetítették. Az 1765-ben alapított hamburgi patrióta egyesület, (Die Hamburgische patriotische Gesellschaft zur Beförderung der Künste und nützlichen Gewerbe) alapítása Biedermann kutatásai alapján egyértelműen londoni példa alapján történt. Az írónőt idézve: A hamburgi patrióta egyesület 1765-bel alakult meg londoni minta alapján.

\footnotetext{
${ }^{73}$ Reising (1994), 112.o. , Zit.: Geschichte der Gesellschaft zusammengeschrieben von Johann Heinrich Meyer, 1787 - 1809. Ms. Kunsthaus Zürich, Sig. AG. 169, 4f.o.

${ }^{74}$ Biedermann (2001), 20.o.

${ }^{75}$ Biedermann (2001), 30. o.: „Die 1754 ebenfalls in London entstandene „Society for the Encouragement of Arts, Manufactures and Commerce" kombinierte die einheimische Gewerbeförderung mit der Vergabe der Preisen für Historienbilder, Skulpturen und Architekturzeichnungen sowie der Organisation von Ausstellungen. [...] Die „Britisch Institution“ war hingehen der erste Zusammenschluß von Kunstfreunden, der sich nahezu ausschließlich um die Förderung der zeitgenössischen Künstler kümmerte.“

${ }^{76}$ Szvoboda Dománszky Gabriella (2001/2 - 3), 32-33.o.
} 
Közép-Európában a polgári összefogás ezen fajtájának első példái közé tartozik és később további alapításoknál példaképül szolgált‘، 77

A Magyar Műegylet megalapításának fontos előzményeként tekinthető a Nemzeti Képcsarnokot Létesítő Egylet megalakulása, ami legfontosabb céljának a magyar festészetet támogatását tekintette. Alapító tagjaiank létszáma meghaladta a százat. Az 1845-ben létrejött Nemzeti Galéria, időről-időre gazdagodó gyüjteménye révén, pedig lehetővé tette, hogy a fiatal magyar tehetséges müvészgeneráció a festmények másolása révén (ezernyolcázas évek negyvenes, ötvenes éveitől) bővíthesse tudását. Munkácsy Mihály ugyancsak élt ezzel a lehetőséggel mielőtt 1864-ben beiratkozott volna a Bécsi Képzőművészeti Akadémiára.

A Nemzeti Galéria alapítóinak névsorát áttekintve szembetünő, hogy a magyar arisztokrácia csekély számban képviseltette magát. ${ }^{78}$ A magyar arisztokraták többsége tehát a művészet területén az esetek többségében mint laikus mügyüjtő volt jelen, ami Biedermann kutatásait is tekintve nem volt kirívó jelenség a tizenkilencedik század európai nemességének körében. Az angliai példát további útmutatóként tekintve a műkereskedelmi érdeklődés ebben a korai művészettörténeti periódusban többnyire az antik és középkori mütágyak irányában volt élénk. ${ }^{79}$

\footnotetext{
${ }^{77}$ Biedermann (2001), 20. o. „[...] 1765 wird nach Londoner Vorbild die Hamburgische patriotische Gesellschaft zur Beförderung der Künste und nützlichen Gewerbe gegründet. Sie zählt zu den frühen Beispielen bürgerlicher Zusammenschlüsse dieser Art in Mitteleuropa und wurde zum Vorbild für weitere Gründungen.“

${ }^{78}$ Magyar Müvészet (1821.) VI., 590.o.

${ }^{79}$ Biedermann (2001), 30.o.
} 


\subsection{A Monarchia két nagy múvészeti egylete: a Bécsi Múvészeti Egylet és a Pesti Müegylet}

\subsubsection{A Bécsi Múvészeti Egylet ${ }^{80,81}$}

A Habsburg Birodalom központjául szolgáló Bécs müvészeti életének intézményes oktatási keretei a tizennyolcadik századra nyúlnak vissza. Egy mủvészeti oktatási intézmény megalapításának igénye már Mária Terézia uralkodása alatt felbukkant és uralkodói támogatással valósult meg. 1768-ban nyitotta meg kapuit a Császári és Királyi Szabad Rézmetsző Akadémia, „K. K. freie Kupferstecherakademie“ amelynek az uralkodónő különleges kiváltságokat adományozott. 1812-ben az intézményt újjászervezték Osztrák Császári Egyesített Képzőművészeti Akadémiára. 1848 után az újonnan megalapított Vallás- és Oktatási Minisztérium igazgatta, majd 1860 után az egyik állam-minisztérium irányítása alá került. ${ }^{82}$

Az első osztrák müvészeti egylet, a Bécsi Művészeti Egylet (,Verein zur Beförderung der bildenden Künste“") 1831-ben alakult meg. ${ }^{83}$ Két szekcióra bomlott. Az első a

\footnotetext{
${ }^{80}$ A bécsi művészeti egyletek története a magyar művészeti szakirodalomban hiányos. A szerző Wladimir Aichelburg (1986), Das Wiener Künstlerhaus című könyvének kézirata és annak szíves közlései alapján dolgozta fel az adatokat és információkat.

${ }^{81}$ Polenyák Ivett (2010), 469-470.o.

${ }^{82}$ Oesterreichische-Ungarische Revue (1865), Kunst und Kunstvereine in Wien. III. Jg., IV. Bd. 245.o.: „Die ersten wichtigen Schritte im Bereich des Kunstunterrichtes geschahen schon unter der Herrschaft von Maria Theresia, die die „k. k. freie Kupferstecherakademie“ im Jahr 1768 besondere Statuten schenkte. Später, 1812, wurde dieses Institut reorganisiert und unter dem Namen „ÖsterreichischKaiserliche Akademie der vereinigten bildenden Künste“ dem Ministerium der „auswärtigen Angelegenheiten“ untergeordnet. Nach 1848 wurde es in das neu errichtete Ministerium für Cultus und Unterricht verlegt. Nach dessen Aufhebung im Jahre 1860 übernahm es das Staatsministerium.“

${ }^{83}$ August Schaeffer (1917), 50 Jahre Wiener Künstler-Genossenschaft unter Kaiser Franz Joseph I, 1.o. Kézirat. Wladimir Aichelburg közremüködésének köszönhetően dolgozhatott belőle a szerző. Wiener Stadt und Landesarchiv.
} 
festészetre, a második a monumentális mütárgyak alkotására koncentrált. ${ }^{84} \mathrm{Az}$ ötvenes években az osztrák művészeti egyesületek száma már háromra emelkedett. Az Albrecht Dürer Egyesület („Albrecht Dürer Verein“, 1845) és az Egyetértés („Eintracht“, 1857) az elsőként megalapított egyesületből („Beförderung der bildenden Künste“) vált ki. ${ }^{85}$ Az Albrecht Dürer Egyesület 1845-ben alakult. A már meglévő egyesületektől az különböztette meg, hogy az Itáliából hazatért osztrák professzornak, Heinrich Schwemmingernek köszönhetően az itáliai müvészeti egyletek szellemében kezdett el munkálkodni, felismerve azt, hogy milyen fontos szerepe van a müvészek egymás közötti kapcsolatának, véleménycseréjének, aminek teret kell biztosíani. Ezért ezt az itáliai egyesületi formáknak megfelelően alakította át. ${ }^{86}$ Az Eintracht megalapítása után egy évvel később a két egyesület már együttmüködött egymással. Idővel az osztrák egyesületek összeolvadtak. Így alakult meg 1961. Április 29-en a Bécsi Képzőművészek Társasága (die Genossenschaft der bildenden Künstler Wiens). ${ }^{87}$

A Bécsi Mủvészeti Egylet által rendezett kiállítások főleg az Akadémiáról kikerülő mütárgyakra épült. A kiállítások többek között azt a célt is szolgálták, hogy az egyesület tagjai között megrendezett sorsolások (Lotterie) révén piacot teremtsenek a hazai osztrák müvészeknek. Bécsi Művészeti Egylet által rendezett kiállítások egészen az 1850-es évekig rendszertelenek voltak. Az ezt követő években változás következett be az egyesület életében, ami külföldi müvészeti egyesületekkel kialakított kapcsolatoknak volt köszönhető. 1857-ben az Egyesület a Stuttgartban rendezett második német

\footnotetext{
${ }^{84}$ Schaeffer (1917), 1.o.: „Der „Mutterverein“ wurde später in zwei Sektionen gegliedert: die erste Sektion konzentrierte sich auf die Malerei, die zweite Sektion war für die Hervorrufung monumentaler Kunstwerke zuständig.“

${ }^{85}$ Schaeffer (1917), 3.o. :,Diese drei genannten Vereine waren so ziemlich an und auf der bildenden Künstler Wiens, eine den künstlerischen sowie materiellen Interessen der nachwachsenden österreichischen Künstler schar dienende Vereinigung bestand somit nicht und als nun vollends der heimische Kunsthandel, der bisher vorzüglich die Altwiener gepflegt hatte, sich den Ausländern zuwendete und auch das Publikum der neuen Geschmacksrichtung folgte, drängten die Ereignisse in jeder Beziehung zu einer Vereinigung der jungen Künstler Wiens.“

${ }^{86}$ Schaeffer (1917), 3.o.

${ }^{87}$ Wladimir Aichelburg, Das Wiener Künstlerhaus 1861- 1986. 125 Jahre in Bilddokumenten, 28.o.
} 
mủvésztalálkozón és a Nürnbergben megrendezett történelmi müvészet egyesületeinek a találkozóján részt vett, s elhatározták, hogy 1858-ban Münchenben a német közös történelmi müvészeti kiállításon is részt fognak venni. ${ }^{88}$

\section{3. ábra A Bécsi Müvészeti Egylet kiállított mütárgyainak és festményeinek száma}

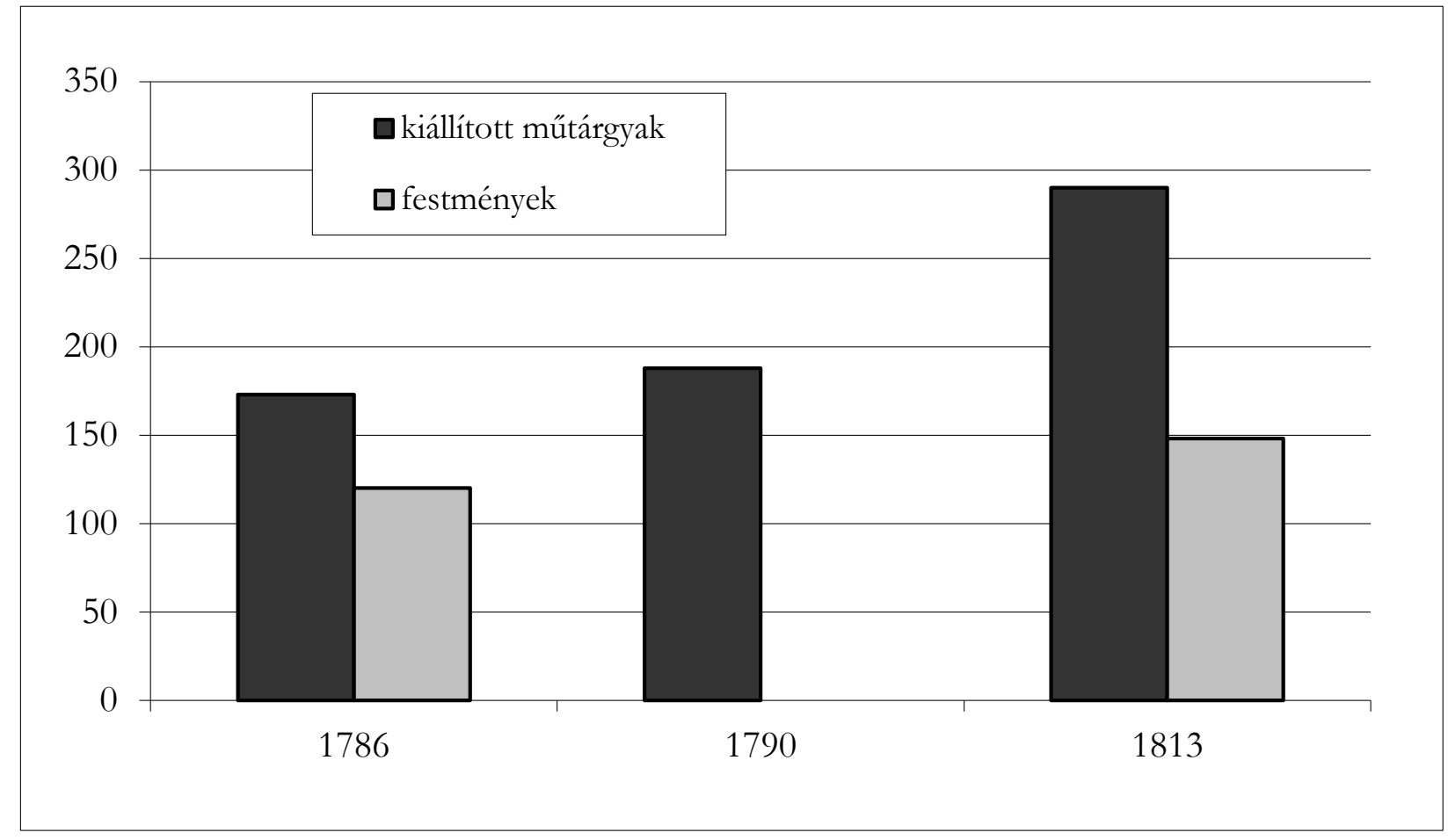

Forrás: Oesterreichisch-Ungarische Revue (1865), III. évf., IV. kötet. Kunst und Kunstvereine in Wien. 245.o.

Az 1850-es évek végén láthatóan felélénkültek és széles körben kiépültek az egylet kapcsolatai külföldi, elsősorban német müvészeti egyesületekkel, aminek következtében a művészegylet rendezte kiállítások nemzetközi színezetet nyertek. A támogatóiknak köszönhetően az egyesület évről-évre közre adta egy-egy hazai müvész munkáját másolat formájában. Az „Eintracht“ név alatt 1857-ben alakult újabb müvészeti

\footnotetext{
${ }^{88}$ Schaeffer (1917), 5.0.: „Im Jahr 1857 trat der Wiener Verein der zweiten deutschen Künstlerversammlung in Stuttgart und der Delegiertenversammlung des Vereines für historische Kunst in Nürnberg bei und 1858 schloss er sich der deutschen allgemeinen und historischen Kunstausstellung in München an.“
} 
egyesület. Alapítói névsorában találjuk a már többször idézett August Schaeffer nevét is, akinek kiadatlan munkájából vált számomra lehetségessé pontos képet alkotni és rekonstruálni a bécsi müvészeti egyesületek létrejöttének történetét. Az egylet megalakulása után egy bécsi müvészalbumot jelentetett meg. ${ }^{89} \mathrm{Az}$ új egylet népszerüségét jelzi támogató tagjainak növekvő száma, ami egy év leforgása alatt már 1500 före emelkedett. ${ }^{90}$ Elődei példáját követve különböző külföldi egyesületekkel építettek ki kapcsolatokat. Tagjai Stuttgartban a második német, majd 1857-ben a Nürnbergben megrendezett történelmi müvészet egyesületeinek a találkozóján is jelen voltak. Az elküldött képek között megtalálható volt egy Markó Károly által festett festmény is „Einige ideale Landschaften“ címmel. A magyar történelemhez kapcsolódott az a Peter Kraft által festett kép, ami Zrínyi utolsó kirohanását ábrázolta. Az osztrák müvészek kiállított munkái gyorsan a látogató közönség figyelmének a középpontjába kerültek. Sikerüknek köszönhetően néhány osztrák müvész az Össznémet Művészeti Egyesület tagjává válhatott. Egy évvel később 1858-ban együttműködésre lépett az Albrecht Dürer Egyesület és az Egyetértés. Felléptüknek köszönhetően a külföldi kiállításhoz (például 1858-ban Münchenben a német közös történelmi művészeti kiállítás) a későbbiekben a Bécsi Képzőművészeti Akadémia és a Belvedere Galéria is csatlakozott.

Ezen tapasztalatoknak köszönhetően 1861. április 29-én Bécs képzőművészeinek a közössége névvel, die „Genossenschaft" ${ }^{\text {911 }}$ új egylet látott napvilágot. Az alapító okirata 142 tag $^{92}$ nevét tartalmazza. Ez a művészeti közösség már megalapításának kezdetétől a Habsburg-udvar támogatását élvezhette, ami több tettben is megnyilvánult. Előszőr is a „Genossenschaft“ tíz évre adómentességet kapott, ${ }^{93}$ majd később, 1864. április 12.-én

\footnotetext{
${ }^{89}$ Wladimir Aichelburg (1986), Das Wiener Künstlerhaus 1861-1986. 125 Jahre in Bilddokumenten. 11.o.

${ }^{90}$ Schaeffer (1917), 5.o.

${ }^{91}$ Wladimir Aichelburg (1986), 7.o.

${ }^{92}$ Schaeffer (1917), 7.o.

${ }^{93}$ Schaeffer (1917), 21.o.
} 
145.325 forint összeg támogatásban részesült a Habsburg udvar, az arisztokrácia és a polgárság részéröl. ${ }^{94}$

Ha részletesen megvizsgáljuk az egyesület kiállításainak a későbbiekben helytadó Künstlerhaus ${ }^{95}$ támogatóinak a névsorát, akkor a következő prominens lista állítható össze. A császár 60000 forintot, a császárné 3000 forintot, Mexikó császára, azaz Miksa főherceg 4500 forintot adományozott. A főhercegek közül Károly Ferenc, Lajos Károly, József Lajos, Albrecht és Vilmos személyenként 3000 forint adománnyal járult hozzá a Müvészház megnyitásához. Coburg hercege 4000 forint, Vinzenz Auersperg és gróf Bouquoi 3000 forintnyi összeget szánt erre a célra. Az osztrák nagypolgári családok, vetekedve az arisztokraták által felajánlott támogatásokkal, ugyancsak nagy pénzbeli felajánlásokat tettek. Például Nicolaus Dumba, Anton Fischer von Ankern vagy Philipp Haas 3000 forintot ajánlottak a Bécsi Művészház támogatására. ${ }^{96}$ Kiemelkedő még magyar szempontból a Batthány család adománya, ami az ugyancsak arisztokrata Lichtenstein, Schwarzenberg vagy a Kinsky családok által megajánlott 3000 forinttal megegyezett. ${ }^{97}$

Az egyház ugyancsak képviseltette magát a támogatók táborában. A melki, a klosterineuburgi és a schotteni apátság mellett a kolostorok is (Zwettl, Geres, Seitenstätten és Herzogenburg) is fellelhetők az adományozók listán. Összefogásuk nem kevesebb mint 3000 forintot eredményezett. ${ }^{98}$ Maga a Bécsi Művészeti Akadémia, az Osztrák Müvészeti Egyesület 3000 forintot, valamint a Képzőmúvészeti Egyesület is adományozott 27.150 forintot a Művészház építésére. Az alapítók összesen 145. 925 forintot gyüjtöttek össze. ${ }^{99}$ A londoni világkiállításon a „Genossenschaft“ művészeinek

\footnotetext{
${ }^{94}$ Schaeffer (1917), 21.o.

${ }^{95}$ 1865-1868 között építették fel Bécs első kerületében az épületet. Megnyitásától 2013-ig képzőművészeti kiállításoknak adott helyet.

${ }^{96}$ Julius, Mirko und Gerstenbrand, Alfred (1965), 9-10.o.

${ }^{97}$ Schaeffer (1917), 21.o.

${ }^{98}$ Schaeffer (1917), 21.o.

${ }^{99}$ Schaeffer (1917), 22.o.
} 
alkotásai is szerepeltek, amelyek között megtalálható volt Karl Rahl bécsi festőmüvész, valamint Than Mór festményei is.

\subsubsection{A Pesti Múegylet: Az első magyar múvészeti egyesület megalakulásához vezető út ${ }^{100}$}

Mária Terézia uralkodása alatt a magyar képzőmüvészet ügye a Királyi Magyarországon összehasonlítva az uralkodóház ennek támogatására, felkarolására tett ausztriai lépéseivel nagyon gyenge lábakon állt. ${ }^{101}$ Természetesen a magyar arisztokraták és a felvilágosultabb polgári rétegek műveltségüknek köszönhetően tisztában voltak azzal, hogy a művészeti ismeretek elsajátítására, kibővítésére az ezt szolgáló intézények, egyletek megalapítására nagy szükség lenne. Megelőzve a reformkori kezdeményezéseket, a Magyar Művészeti Akadémia megalapításának igénye már 1794-ben felbukkant ${ }^{102}$, de tekintve a bécsi alapítás dátumát, így is huszonhárom éves késéssel jelentkezett. A megvalósításban a megkésettség még nagyobb volt, hiszen míg Mária Terézia 1768-ban Bécsben már különleges kiváltságokkal segítette elő a Bécsi Akadémia müködését, addig a Magyar Királyi Országos Mintarajztanoda és

\footnotetext{
${ }^{100}$ Polenyák Ivett (2010), 471 -475.o.

${ }^{101}$ Lyka ed. (1902), Művészet, I. évf., 3. kötet. : „,...] még a leggazdagabb főnemesek sem igen törekedtek akkor képekre, igy a dúsgazdag Grassalkovich Antal még illatos vizekkel táplált szökökutat is csináltatott kertjében, lehozatta Gödöllőre a bécsi udvari theatrum énekeseit, de egyetlenegy kép sem fügött a termekben. Ezen Mária Terézia, mikor látogatóba járt az őt fejedelmi fénynyel fogadó nagy úrnál , meg is ütközött.-De kedves grófom, nem veszi észre mennyire hiányoznak önnél a képek? Mondta a királynő.

Az udvarias gróf azonban úgy vágta ki magát, hogy nem lévén meg uralkodójának a képe, más képet előbb házába hozni méltatlannak tartotta. A bók annyira megtetszett Mária Teréziának, hogy hazatérve Bécsbe úgy a saját, mint Lotharingiai Ferenc arcképét is megküldte Grassalkovichnak.“

${ }^{102}$ Schauff Nepomuk János (1794), Allgemeine Begriffe von Künsten und Künstlern angewendet auf die bildende Künste. Pozsony.
} 
Rajztanárképezde $^{103}$ csak százhárom éves késéssel, 1871-től kezdhette meg a müködését. Ennek ellenére a magyar kezdeményezések története igen hosszú.

Schauff Nepomuk János ${ }^{104,105}$ 1804-ben egy felhívást tett közzé a „Zeitschrift von und für Ungarn“ című lapban, amelyben a magyar művészet ügyének felkarolására és intézményesítéséért emelt szót, és ennek első lépéseként egy múzeum felállítását szorgalmazta. ${ }^{106}$ A Tudományos Gyüjtemény cikkei mutatják, hogy a korszak felvilágosult gondolkodóit foglalkoztatta a nemzeti képzőmủvészet ügye, annak megfelelő szintre való felemelése, amit a nemzeti kulturális felemelkedés részeként tekintettek.

Hesz János Mihály ${ }^{107}$, aki Bécsben tanárként és képzőművészként egyaránt dolgozott, 1820- ban kiadott munkájában egy magyar művészeti akadémia megalapításának szükségességéröl ír. Ezen intézmény tanrendjét a már meglévő és működő Bécsi Akadémia szabályzatával és tervezetével összhangban készítette el. Ferenczi István ${ }^{108}$ 1836-ban egy szobrászati iskola tervezetét terjesztette be a pozsonyi országgyülés elé, de terve visszhang nélkül maradt. Ennek ellenére a lelkes müvészetpártoló Bécsbe utazott, és a királyi udvarhoz folyamodott támogatásért, de eredménytelenül távozott az udvarból. ${ }^{109}$

\footnotetext{
${ }^{103}$ Szabó László (1989), A művészeti oktatás kérdése Magyarországon a 19. század elején. Ars Hungarica, 1989, 2. szám. 133-146., Blaskóné Majkó Katalin, Szőke Annamária ed. (2002), A Mintarajztanodától a Képzőművészeti Főiskoláig. Magyar Képzőmüvészeti Egyetem, Budapest.

${ }^{104}$ Schauff Napomuk János (1757-1827), festő, rézmetsző, műkereskedő. Pozsonyban általános iskolai tanár volt. Cikkei jelentek meg a pozsonyi múzeumok évkönyvében és a Magyarországért és Magyarországról címü folyóiratban.

${ }^{105}$ Zádor Anna ed. (1962), Magyar Művészet 1800-1945. A magyarországi művészet a XIX. század első felében. A nemzeti művészet kezdetei. 76.o.

${ }^{106}$ Tudományos Gyüjtemény (1821), X., 68-69.o.

${ }^{107}$ Mihály János Hesz (1768-1833), festő és rézmetsző. Marastoni pesti iskolájában, majd Bécsben tanult.

${ }^{108}$ Ferenczy István (1792-1856), szobrász. In: Zádor Anna ed. (1962), A magyarországi művészet a XIX. század első felében. A nemzeti müvészet kezdetei. 76.o., 488.o.

${ }^{109}$ Lyka Károly (1922), A táblabíró világ művészete: Magyar művészet 1800-1850. 169.o.
} 
Joó János ${ }^{110}$ 1841-ben Széchenyi Istvánhoz írt levelében javaslatot tett egy művészeti egyesület létrehozására a magyar művészet támogatásának érdekében. ${ }^{11,112}$ Novák Dániel 1835-ben a müvészeti problématikáját úgy fogalmazta meg, hogy mindaddig, amíg a hazának müvészeti akadémiája nincs, addig a képzőmüvészet még száz évig feltöretlen vidék, ugar marad. ${ }^{113}$ Az idézett szövegek azt is világossá teszik, hogy Bécsnek nagyon fontos, példaadó szerep jutott. Hesz János Mihály ${ }^{114}$ 1820-ban benyújtott petíciójának részleteiben való vizsgálata alapján a következő megállapításokat tehetjük: Hesz a megalapítandó Akadémia financiális támogatását is részletesen kifejtette, ebben a magyar arisztokráciának meghatározó szerepet szánt. Az akadémia megalapítására adományok útján egy alapítvány létrehozását szorgalmazta. Az államnak nem szánt meghatározó szerepet, egyedül az akadémia számára szükséges épület adományozását kérte volna az uralkodótól. A művészeti intézmény igazgatói posztját a saját maga számára tartotta fenn, amelynek vezetését mindennemü fizetség nélkül vállalta volna. Sajnos a kezdeményezés támogatottság hiányában nem valósult meg. A bécsi és a magyar müvészeti egylet alapításának dátuma között a magyar müvészeti élet területén megmutatkozó nagy elmaradottság ellenére csupán nyolc év volt a különbség. Ennek az elmaradottságnak a tükrében a magyar kezdeményezés a bécsi viszonyokat tekintve kisebb csodaként is felfogható.

Lyka Károly ${ }^{115,116}$ kutatásai nyomán a Magyar Művészeti Egylet megalapításának dátumát 1840-re teszi. Ennek ellentmond az Oesterreichisch-Ungarische Revue által

\footnotetext{
${ }^{110}$ Joó János (1807-1874), az Egri érseki Gimnázium rajztanára, világi pap aki a gimnázium könyvnyomdájának a vezetője is volt.

${ }^{111}$ Lyka Károly (1841), Müvészet III., 103.o.

${ }^{112}$ Zádor Anna ed. (1962), Magyar Müvészet 1800-1945. A magyarországi művészet a XIX.század első felében. A nemzeti müvészet kezdetei. 76.o.

${ }^{113}$ Lyka Károly (1835), Müvészet XI. 130.o.

${ }^{114}$ Hesz János Mihály (1768-1830), festő. In: Zádor Anna ed. (1962), 76. o., 489.o.

${ }^{115}$ Lyka Károly (1942), Nemzeti Romantika. Magyar Művészet, 1850-1867., 20.o.

${ }^{116}$ Révész Emese (2005), A magyar historizmus, A polgári és állami müpártolás új formái. 49-50.o.
} 
közölt napot is közlő dátum, ami 1839. szeptember 9-ét jelöli meg. ${ }^{117,118}$ Az alapító tagok között, akik felismerték ennek a kulturális intézmény életrehívásának a fontosságát, azokkal az alábbi nevekkel találkozhatunk, akik a magyar művészet élet intézményes kereteinek a megteremtésében fontos szerepet vállaltak: Eötvös József, Lukács Móricz, a pesti egyetem esztétika professzora, Schedius Lajos, Dr. Eckstein Frigyes, Grimm Vince, Gróf Serényi Lajos és Trefort Ágoston. Megalapítása nemcsak a magyar élő müvészet nyílvános fórumaként, hanem a kortárs európai, főleg osztrák és német müvészetek bemutatásának is teret engedett. A domináns osztrák példa mellett ${ }^{119}$ meg kell említenünk, hogy a prágai művészeti egylet alapítása sem hagyhatta minden visszhang nélkül a magyar művészeti egyletet. ${ }^{120} 1839$. november 10 -én hivatali úton is engedélyezték az egylet müködését. Trefort Ágostont választották meg az elnökének, Szalay Lászlót a titkárának, Grimm Vincét pedig pénztárosának. ${ }^{121}$

Bayer József 1904-ben írt cikke ${ }^{122}$ Frankenburg Adolf ${ }^{123}$ és Gerandó Ágost ${ }^{124}$ publicisták írásai nyomán formált véleményt a Pesti Műegylet müködéséről. Ezek alapján elítélően nyilatkozik annak a müvészeti életben betöltött szerepéről, nem

\footnotetext{
${ }^{117}$ Oesterreichisch-Ungarische Revue 1865.Kunst und Kunstverein in Ungarn. III. évf., V. kötet., 231.o.

${ }^{118}$ Zádor Anna ed. (1962), 77.o.

${ }^{119}$ Schaeffer (1917), 3.o.

${ }^{120}$ Oesterreichisch-Ungarische Revue (1865), III. évf., V. kötet, 233. o.: „Ein Ausfluss dieses Geistes war in Ungarn wie in Böhmen die fast gleichzeitige Stiftung eines Kunstvereines. Den ersten Anlass zur Gründung eines solchen in Pest hat offenbare die Entstehung der Kunstvereine in Wien und Böhmen gegeben.“

${ }^{121}$ Oesterreichisch-Ungarische Revue 1865.Kunst und Kunstverein in Ungarn.III. évf., V. kötet, 233.o.

${ }^{122}$ Lyka Károly (1904), Művészet, III. évf., 3. szám, Bayer József: A Pesti Mủegylet kezdeményezői és első megtámadói. 170-176.o.: „Sajnos, mindkét felfogásnak az a végső eredménye, hogy a Pesti Müegylet egy időelötti, müvészi nevelésre képtelen, céljai iránt tisztában nem lévő, nemzeti erős érzület dolgában joggal kifogásolható, oly dilettáns jellegủ társaság , mely többet ártott, mint használt megalakulásával.“

${ }^{123}$ Frankenburg Adolf (1811-1884), humanista és emlékíró, az MTA levelező, a Kisfaludy Társaság rendes és a Petőfi Társaság tiszteletbeli tagja.

${ }^{124}$ Auguste de Gérando (1819-1849) francia esszéíró, földbirtokos, a Magyar Tudományos Akadémia külső tagja.
} 
méltányolva az Egylet körülményeit és lehetőségeit. A magyar közéletben betöltött szerepe ezzel ellentétben pozitív visszhangra talált, a múvészet a köztudatban is kezdte megtalálni a helyét, amit a támogatók növekvő száma is hivatott alátámasztani. A Pesti Müegylet fenntartását és működését biztosító részvényeseinek számbeli változását az Oesterreichisch-Ungarische Revue közzétett adatai alapján megrajzolt ábra mutatja. ${ }^{125}$

4. ábra A Pesti Mủegylet részvényeinek száma 1840 és 1858 között

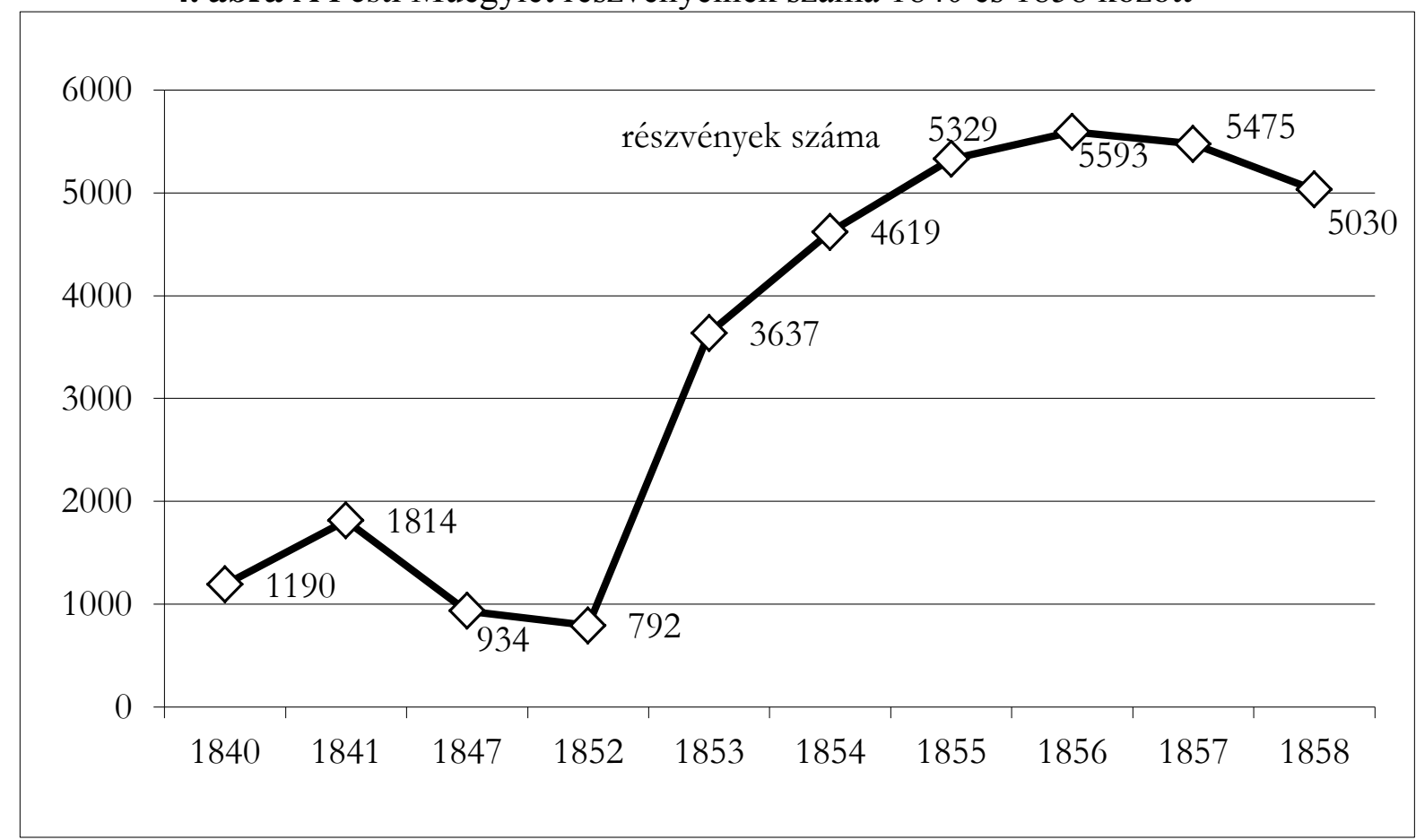

Forrás: Oesterreichisch-Ungarische Revue (1865), Kunst und Kunstverein in Ungarn. 3(5), 231.o.

1840-ben az egylet pártolóinak jóvoltából az eladott részvények száma 1190-re nőtt és az 1840-es évekig realatíve stabilnak muatkozott. A század végére jelentős gyarapodás figyelhető meg, így 1856-ra már 5500 részvényessel számolhattak. Az eladott részvények növekvő számával párhuzamban megállapítható, hogy a magyar közönség érdeklődése a művészet irányába nőtt, kulturális igénye kiszélesedett.

\footnotetext{
${ }^{125}$ Polenyák Ivett (2010), Die Rolle des Mäzenatentums in Österreich-Ungarn im Spiegel der Kunstvereine, in: Hlavacka, M., Pokorná, M., T.W. Pavlícek (eds): Collective and Individual Patronage and the Culture of Public Donation in Civil Society in the 19th and 20th Centuries in Central Europe. The Institute of History Prague, Prága.
} 
5. ábra A Pesti Mủegylet első kiállításán kiállított és eladott festmények aránya és a résztvevő festőművészek nemzetiségi megoszlása

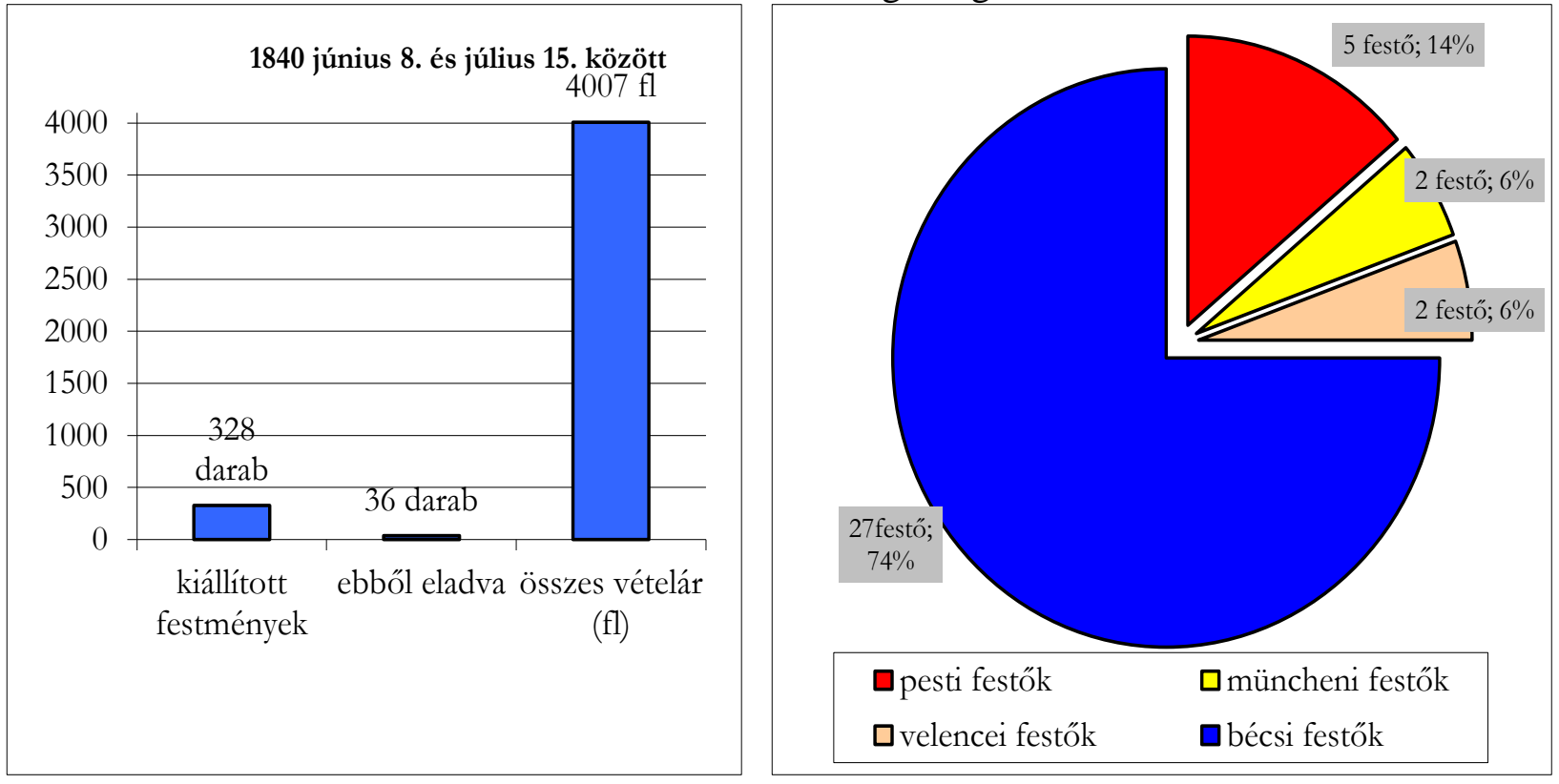

Forrás: Oesterreichisch-Ungarische Revue (1865), Kunst und Kunstverein in Ungarn. 3(5), 231. o.

A Pesti Műegylet első kiállításai nem állandó kiállítasok voltak. A Műegylet 1940 júniusban ${ }^{126}$ szervezte az első nyilvános kiállítását. A 36 kiállított kép közül öt volt magyar mủvész alkotása. A festmények zömét osztrák festette. Ezek a számok azt mutatják, hogy a kiállítás nem volt túl nemzetközi. ${ }^{127}$

A hazafiasság hiányát gyakran kritizálták: a Müegylet bécsi festőket hívott meg a kiállításaira. Noha nem legjobb képeiket állitották ki, ezen festök képzettebbek voltak magyar társaiknál. Néhány, a Bécsi Akadémián tanuló festő volt a kivétel. ${ }^{128} \mathrm{~A}$ Múegylet ezzel nagyon is tisztában volt. A Mủegylet nem helyettesíthette az

\footnotetext{
${ }^{126}$ Oesterreichisch-Ungarische Revue 1865. Kunst und Kunstverein in Ungarn. III.Jg., V. Bd., p. 233.

${ }^{127}$ Polenyák, Ivett (2012), The Influence of the Venetian Scool on the development of Hungarian painting arts, as intermediated, in: Conference proceedings, International Institute of Social and Economic Sciences, Palermo, Sicily, 2012, április 15-18. ISBN: 978-80-905241-0-1.

128 They were Károly Markó, József Borsos, Albert Tikos, Szale, Károly Lajos Libay and Miklós Barabás.
} 
intézményesített müvészeti képzést. Csupán müvészeti iránymutatással szolgálhatott. A Mủegyletet kritika érte amiatt is, ahogyan a festményeket vásárolta: a megvásárolt képeket a részvényesek között sorsolták ki. Noha ez biztosította a pénzügyi túlélését, gyakran elhangzott az az érv, miszerint a lehető legtöbb festményt akarta megvásárolni a lehető legalacsonyabb áron.

De mit is jelentett a képek vásárlása? A képek megvásárlása és kisorsolása valójában a kultúrát és müvészeteket a magyar társadalom szélesebb köreiben népszerüsítette. Ez egyben a Mủegylet részvénytulajdonosainak a számának az emelkedését is jelentette. A korabeli sajtó és a jelenkori szakirodalom általában megfeledkezik arról a tényről, hogy a Mủegylet támogatta a Magyar Nemzeti Galériát. ${ }^{129}$ Ezért nehéz elfogadni azt az érvelést, hogy a Müegylet negatív hatással volt a magyar kulturális életre.

\subsection{A magyar múvészeti intézmények sajátosságai}

A magyar müvészeti intézmények közül a Magyar Állami Képtár - Nemzeti Képcsarnok $^{130}$ megalakulása is sajátos vonásokat hordozott. Ezek közül a leghangsúlyosabb, ami más, nyugat-európai állami képtáraktól megkülönböztette az volt, hogy magángyüjteményekből (például Pyrker János László esztergomi érsek gyüjteménye $\left.{ }^{131}\right)$, adományokból jött létre. ${ }^{132,133}$

\footnotetext{
${ }^{129}$ Oesterreichisch-Ungarische Revue (1865), 233. o: „, az éves bevételekből 400 forintot félre kellett tenni (...) amit kamataival együtt a Nemzeti Galériának kellett adományozni“

${ }^{130} 1851$-ben nyílt meg. Anyagát az 1845-ben megalakult Nemzeti Képcsarnokot Alapító Egyesület vetette meg, akik magyar müvészek alkotásait vásárolták meg: Barabás Miklós, Ligeti Antal, Kiss Bálint, Brodszky Sándor.

${ }^{131}$ Révész Emese (2005), A magyar historizmus. A polgári és állami műpártolás új formái. 45-46.o.

${ }^{132}$ Szvoboda Dománszky Gabriella (1999), 90.o.:,,A magyar állami képtár - eltérően a nagy európai alapítású közgyüjteményektől (Angliát kivéve) - magángyüjteményekből - adományokból fejlödött ki. Az adományokat kiegészítö állami vásárlásokra csak 1867 után került sor, így jelképesen az 1871-es dátumhoz köthetjük müvészeti intézményeink kiteljesedését.“
} 
A magyar kulturális élet felsőbb társadalmi rétegek általi támogatását az 1865-ben az „Oesterreichisch-Ungarische Revue“ hasábjain megjelenő tanulmány is hivatott igazolni: „Ismeretes, hogy a magyar főnemesség, vagyis azok, akik a Monarchia leggazdagabb nemesi közé tartoznak, vetekedve a cseh nemességgel, kapcsolataiknak köszönhetöen nagyon sokat tettek hazájukért. Számukra nagyon fontos volt, hogy Magyarország semmiben se szenvedjen hiányt, amit Európa első kultúrnépei élveznek. Szintén fontos volt, hogy patrióták módjára, tervszerüen mindent megmozgassanak e cél elérése érdekében. Alapítottak egy Nemzeti Színházat, a dráma és az opera számára díjjakat hoztak létre, továbbá alapitottak egy müvészeti iskolát, egy Nemzeti Galériát, egy Tudományos Akadémiát és egy Nemzeti Múzeumot. A legrövidebb időn belül magyar tudományt, magyar irodalmat és magyar müvészetet akartak teremteni [...] Ennek szellemében alakult meg majdnem egyidejűleg Magyarországon és Csehországban is a mủvészeti egylet. ${ }^{134}$

A fentebb idézett forrásból nem derül ki, hogy a magyar kulturális élet támogatói között ott találjuk a nagypolgárság képviselőit is, számos képviselőjük vett részt adományaik révén egy-egy kulturális intézmény életrehívásában. Csak egy példát emelve ki: a Mücsarnok $^{135}$ 1877-es adományokat összegző listáján megtalálhatóak ezen családok képviselőinek aláírásai is. Ezek a nagypolgári, tehetős családok, akik ezen müpártoló

\footnotetext{
${ }^{133}$ Sinkó Katalin (2009), Nemzeti Képtár. In: Magyar Nemzeti Galéria Évkönyve 2008. XXVI, No. 11.

${ }^{134}$ Oesterreichisch-Ungarische Revue (1865), 3. évf., 5. kötet., Kunst und Kunstverein in Ungarn. 232233.o.

„Es ist bekannt, was der ungarische Adel, der reichste der Monarchie, in rühmlichen Wetteifer mit dem böhmischen, in all diesen Beziehungen für sein Vaterland gethan hat. In seinen Augen galt es Ehrenpunct, dass Ungarn an nichts Mangel leiden sollte, was die ersten Culturvölker Europa`s genießen, und die Thätigkeit, welche die ungarischen Patrioten entstalteten, um ihm das zu diesem Ziel Fehlende, nicht viel weniger als Alles, zu schaffen, war eine planmäßige. Ein Nationaltheater wurde gestiftet, Preise für Drama und Oper wurden ausgesetzt, eine Kunstschule und eine Nationalgalerie angeregt, eine Akademie der Wissenschaften, ein Nationalmuseum gegründet, in kürzerer Zeit sollte eine magyarische Wissenschaft, magyarische Literatur und magyarische Kunst geschaffen werden. [...] Ein Ausfluß dieses Geistes war in Ungarn wie in Böhmen die fast gleichzeitige Stiftung eines Kunstvereines.“

${ }^{135}$ 1877-ben épült fel a Műcsarnok. A Képzőmüvészeti Társulat kiállításait itt rendezték meg. 1875-ben összeolvadt a Képzőmüvészeti Társulattal.
} 
társadalmi réteg gerincét alkották, az 1867-es ipari fejődés nyomán a Magyar Királyság területén alapított vállalkozásaiknak köszönhették vagyonukat. Ezen vállalkozások életképességét igazolja, hogy hatalmas, az arisztokrata családok vagyonával vetekedő, vagy ezt meg is haladó tőkét sikerült felhalmozniuk. Természetesnek tünik az az igyekezet, hogy tőkéjüket tekintve az előbbiek értékrendjét, szokásait próbálják meg magukévá tenni. ${ }^{136}$ Mivel az arisztokrácia nagyon zárt közösséget alkotott, ezek a vagyonos nagypolgári családok a legegyszerübb és legfontosabb lépésnek az arisztokratákhoz való közeledés érdekében a nemesi cím megszerzését tekintették.

Hatalmuk reprezentálására igyekeztek az arisztokrata birtokok kiterjedésének megfelelő nagyságú birtokokat vásárolni, hiszen az integrálódásra kiszemelt osztálynak az életmódjához, szokásaihoz hasonló életstílust is igyekeztek elsajátítani. Ezen törekvésük az alacsonyabb polgári rétegeket sem hagyta hatás nélkül. A polgári középosztály és kispolgárság életstílusába, mégha nagyon nagy mértékben lekicsinyítve is, de sok új szokást épített be. A megnyíló mükiállításoknak és ennek mülapjainak, majd ezek más lapokban való átvételének is köszönhetően az alsóbb rétegekhez is sikerült eljuttatni a kizárólag a privilégizált rétegekhez társított müvészeti ismereteket és müvészeti alkotásokat.

Az eredeti műtárgyak megvásárlása továbbra is a vagyonos elit kiváltsága maradt, ezek tömeges másolatát azonban megtaláljuk litográfiák, fametszetek és kőnyomatok formájában az alacsonyabb polgári rétegek szalonjaiban is. Ezen idők nagypolgári szalonjai arisztokrata mintára kulturális fórumokként is szolgáltak, melyeknek sok fiatal zenész, énekes, irodalmár, író és képzőmüvész köszönhette karrierje kezdetét. Egy nagyon jó példa ezen állítás igazolására a híres építész Lechner Ödön családjának szalonja. Édesanyja osztrák-német származású volt, s a társasági életre nagy hangsúlyt fektetett. Ennek köszönhetően az ő nagypolgári szalonjukban olyan, a magyar művészeti életben nagy hírnévnek örvendő személyekkel találkozhatunk, mint Liszt

\footnotetext{
${ }^{136}$ Gyáni Gábor, Kövér György(1998), Magyarország társadalomtörténete a reformkortól az első világháborúig. A művelődés rétegei. Kultúra és életforma. 117-127.o.
} 
Ferenc, Richard Wagner, Szigligeti Ede, Goldmark Károly, Erkel Ferenc és Erkel Sándor. ${ }^{137}$

Mecénások hiányában a fiatal müvészek többségének semmi esélye nem lett volna külfödi akadémiákon tanulni, hiszen az állami ösztöndíjak megjelenéséig semmilyen kilátásuk és forrásuk nem volt erre. ${ }^{138,139} \mathrm{Az}$ állam biztosította ösztöndíjak sem bizonyultak megoldásnak, hiszen amint Munkácsy Mihály példája is mutatja, elnyerésükhöz a magyar művészeti életben nevet szerzett híres pártfogókra volt szükség. ${ }^{140}$ E pártfogók maguk is mủvészeti tanulmányaik külföldön való megkezdését, majd tudásuk kiszélesítését kizárólag a főuri, nagypolgári mecénásoknak köszönhették. Említhetjük Ligeti Antal ${ }^{141}$ festőművész pályakezdését, akinek Itáliába majd a KözelKeletre tett tanulmányútját gróf Károlyi István finanszírozta. ${ }^{142}$ Telepy Károlyt ${ }^{143}$ pedig, aki a magyar Mủegylet létrejöttében majd igazgatásában oly felejthetetlen szerepet játszott, Berchtold Matilde bárónő támogatta, és Rómába való utazását is finanszírozta. Velencei tanulmányútjának megvalósulása pedig gróf Csernovics Péter nevéhez füződik. ${ }^{144}$ Ürményi Ferenc pártfogoltja Molnár József volt. ${ }^{145,146}$

\footnotetext{
${ }^{137}$ Kismarty Lechner-Jenö (1961), Lechner Ödön. Képzömüvészeti Alap Kiadóvállalata, Budapest, 20.o.

${ }^{138}$ Révész Emese (2005), A magyar historizmus. A művészet intézményes keretei. 40.o.

${ }^{139}$ Munkácsy Mihály pártfogóinak, úgy mint Ligeti Antalnak, Than Mórnak, Lotz Károlynak és a Müegylet neves irányítóinak köszönhette, hogy a Müegylet kiállíttatta é kisorsoltatta képeit. Ebből számazó jövedelme a Bécsi Akadémiára való beiratkozást tette lehetővé.

${ }^{140} \mathrm{Az}$ Eötvös József által biztosított ösztöndíjhoz is a fentebb felsorolt magyar művészek pártfogása segítségével jutott hozzá.

${ }^{141}$ Ligeti Antal (1823-1890) magyar tájképfestő. Markó Károly tanítványa volt. In: Zádor Anna ed.(1962), 142.o.

${ }^{142}$ Lyka (1942), Nemzeti Romantika, 9.o.

${ }^{143}$ Telepy Károly (1828-1906) magyar tájképfestő. Markó Károly tanítványa volt. In: Zádor Anna ed.(1962), 110.o.

${ }^{144}$ Lyka (1942), Nemzeti Romantika, 10.o.

${ }^{145}$ Molnár József (1821-1899) magyar tájkép- és életkép festő. In: Zádor Anna ed.(1962), 138.o

${ }^{146}$ Lyka (1942), Nemzeti Romantika, 10. o.
} 
A gazdag és feltörekvő nagypolgárság a magyar müvészek és müvészet támogatása, a mecénás szerep gyakorlása révén láthatóvá, demonstrálhatóvá, vagyis érzékelhetővé tehette vagyonát és társadalmi súlyát az arisztokrácia előtt is. ${ }^{147} \mathrm{Az}$ ipar felvirágzásának köszönhetően létrejött vagyonok gazdái kénytelenek voltak egy ún. Janusz arcot, szerepet ölteni magukra, hiszen modern gyáraik és az ezekben alkalmazott új találmányoknak köszönhetően nagy vagyonok urai lettek, de a régi arisztokrata tradícióknak megfelelő nemesi címet és hatalmas birtokokat vásároltak, magukévá téve ezek tradicionális, sok esetben konzervatív értékrendjét. A mecenatúra szokása a császári házban évszázados tradíciókra, hagyományokra tekinthetett vissza. A birodalmi arisztokrácia előtt a császár és családja pedig fontos és követendő példaként szolgált. Az uralkodó mủvészeti életben betöltött mecénási szerepét igyekezett birodalma egészére kiterjeszteni. A nagyobb adományozásokról a hivatalos újság, a Wiener Zeitung is tudósított. Az újság 1864-es napi hírek rovatában ${ }^{148,149}$ például az alábbi adományokról és adományozottakról tett említést:

\footnotetext{
${ }^{147}$ Vörös Károly (1979), Budapest legnagyobb adófizetői 1873-1917., 96.o., Radnóti József (1929), Pesti pénzoligarchák, 107.o.

${ }^{148}$ Wiener Zeitung (1864) - Zur Tagesgeschichte, 860.o. :,G. C. Wie bekannt wurde die ursprünglich zu Kunstausstellungszwecken für die Gemäldegalerie am Belvedere für das Jahr 1864 bestimmt gewesene Dotation von 10.500 fl. Von Seite Hern Staatsministers über Allerhöchste Genehmigung Sr. Majestät zur Unterschtützung österreichischer Künstler in der Wese verwendet, dass bei denselben theils Verstellungen auf Werke gemacht theils vollendete Werke angekauft wurden. Von den auf diesen Wege gewonnenen Kunstwerken haben nun zwei, der bereits ausgeführt, und zwar das angekaufte Gemälde vom Pester Maler Mór Than. ${ }^{148}$ „eine Szene aus einer ungarischen Tragödie von Madach“ und Hans Gassers „Marmorbüste des ungarischen Landschaftsmalers Markó“ die spezielle Bestimmung für das ungarische Nationalmuseum in Pest erhalten, auch wurde bereits die Einleitung getreen, um diese beiden Kunstwerke ihrer Bestimmung zuzuführen zuzuführen.“

${ }^{149}$ Günter Natter (1990), Kaiserliche Ankaufspolitik und staatliche Kunstförderung, In: Gott erhalte Österreich. Religion und Staat in der Kunst des 19. Jahrhunderts. Ausstellung in Schloss Halbturn. Thomas Kletecka (2010), Paradigmawechsel in der österreichischen Kunstförderung des 19. Jahrhunderts. In: Milan Hlavačka, Magdaléna Pokorná and Tomáš W. Pavlíček eds. (2010), Collective and Individual Patronage and the Culture of Public Donation in Civil Society in the 19th and 20th Centuries in Central Europe. 90-130.o., Peter Urbanitsch (2010), Musikmäzenatentum in Wien im letzten Drittel des 19. Jahrhunderts. In: Milan Hlavačka, Magdaléna Pokorná and Tomáš W. Pavlíček eds. (2010), Collective
} 
A császári ház 10.500 forintot adományozott a Belvedere Galériának az 1864-es évre. Ezt az államminiszter ausztriai müvészek támogatására fordítja, részben már elkészült képek vásárlására, részben képek megrendelésére. A pesti festő, Than Mór egyik festményét vásárolta meg. A kép témájának alapjául Madách Imre müve, az ember tragédiája szolgált. Hans Gasser ${ }^{150}$ szobrásztól pedig a magyar tájképfestő Markó Károly ${ }^{151}$ márványból készült mellszobrát vásárolta meg a Magyar Nemzeti Múzeum számára.

\subsection{Munkácsy Mihály és az 1860-as évek múvészeti egyletei}

Az 1850-es és 1860-as évek magyar nagyvárosaiban az elszaporodó egyesületek, egyletek egyre nagyobb szerepet játszottak azok kultúrális életében. ${ }^{152}$ Ennek az aktivitásnak a súlypontja Pest városában volt. Megalapításukban, majd taglétszámuk gyarapodásában fontos szerepet játszottak az akkori magyar közélet kulcsszereplői. Ennek fontosságát, illetve Pest városának vezető szerepét a Temesvár kultúrális életében jelentős szerepet játszó mủvészettörténész Ormos Zsigmond az 1860-as években kelt leveleiben is kellőképpen hangsúlyozta. ${ }^{153}$

and Individual Patronage and the Culture of Public Donation in Civil Society in the 19th and 20th Centuries in Central Europe. 64-90. o.

${ }^{150}$ Hans Gasser (1817-1868), osztrák festő, szobrász.

${ }^{151}$ Markó Károly (1791-1860), In: Zádor Anna ed.(1962), 107.o.

${ }^{152}$ 1852. november 28. Beschlüsse der Generalversammlung nach Andrássy am 28. November 1852.

${ }^{153}$ Országos Széchényi Könyvtár-Kézirattár. Levelestár. Ormos Zsigmond Pulszky Ferenchez. 1900/20. und 1898/22, Fond VIII/764. „Társulatunk (Temesvári régészeti, történeti társulat) [...] a szellemi társasulás és nemzeti irányba egybeolvadás fontos tényezöjét képezi, azonban fájdalom a Központ által illöen méltányolva nincsen. A központtal az egyetlen Pesti Frigyest számítjuk tagjaink közé. Te édes barátom mint nemzeti muzeumi intézetünk irányítója, mint jó hírben álló régész [...] leginkább hivatva vagy arra: hogy azon mind inkább terjedö szakvéleményt, mintha a centrumban a vidék tudományos 
A kisvárosok lakóit sem hagyták érintetlenül az országszerte alapított egyletek gyarapítására irányuló törekvések. Erre egy nagyon jó példa a Munkácsy pályakezdését támogató gyulai egyesület, melynek tagjai, ha szerény keretek között is, de pártfogásba vették a fiatal művészpalántát. Minderről önéletrajzi írásában is megemlékezett az akkor már világhírnévnek örvendő festő. ${ }^{154}$ A Marastoni Jakab ${ }^{155}$ által életre hívott Festészeti Akadémiára szerették vola küldeni, ami csekély támogatottságának dacára nagy hírnévnek örvendett. Munkácsy ebböl a támogatásból Pestre nem, de a kisvárosban dolgozó német ajkú festő, Franz Fischer ${ }^{156}$ mütermébe már eljuthatott. Visszaemlékezése szerint Franz Fischer egykori tanára a Bécsi Művészeti Akadémiát látogatta, de ennek nyoma a Bécsi Képzőművészeti Akadémiai Levéltárban nenm lelhető fel. ${ }^{157}$ Néhány hét elteltével ebben a müteremben ismerhette meg Szamossy Elek $^{158}$ festőmüvészt, aki a fiatalember műveit látva pártfogásába vette. Szamossy barátságát elnyerve nemcsak a magyar, hanem a bécsi művészvilág kapui is feltárultak a fiatalember elött, mégha csak feltételesen is. A magyar müvészeken kívül megismerhette például a magyar kultúrát lelkesen támogató irodalmárt, esztétát, mủvészettörténészt, a dél- magyarországi múzeumok egyesületének egyik alapítótagját,

törekvéseit lenézéssel fogadnánk, tettleg megcáfolja az által hogy május 15 két körünkben töltve [...] társulatunk tagjává légy.“

${ }^{154}$ Munkácsy (1950), 67.o.: [...] egy képkereskedésben kiállítottam apró képeimet s lassankint felém terelődött a közönség figyelme. Nemcsak az az öröm ért, hogy megvásárolták a rajzokat, hanem az a meglepetés is, hogy egy ismeretlen társaság tagjai személyenként havi egy forint segélyt ajánlottak fel tanulmányaim folytatására. Azt akarták, hogy a fővárosba utazzam és iratkozzam be a [Marastoni] akadémiára."

${ }^{155}$ Marastoni Jakab, (1804-1860), festő. Zádor Anna ed.(1962), 77.o., 492.o.

${ }^{156}$ Munkácsy (1950), 59. o.: „Fischer a bécsi festőakadémia tagja volt és visszavonulva élt abban az elhagyott fészekben. Németországban született és egy szót sem tudott magyarul, pedig régóta lakott Gyulán. [...] ö volt hát a „mester“ akitöl tanulnom kellett s akit megkértem, hogy hetenkint három órát adjon nekem. - Szívesen. Miért ne? Válaszolta. Öt perc alatt megegyeztünk. Szükszavú ember volt, de ha keveset beszélt is, annál többet pöfékelt és füstölgetett““

${ }^{157}$ Bécsi Képzőművészeti Akadémia Levéltára. Lásd a mellékletet.

${ }^{158}$ Szamossy Elek (1826-1888) magyar festő, akit honvédfestőként is aposztrofálnak: Emlékkönyv. Kossuth Lajos születésének 150. évfordulójára. II. Akadémiai Kiadó. Budapest., Zádor Anna ed.(1962), 
a Magyar Tudományos Akadémia tagját, Ormos Zsigmondot is. ${ }^{159}$ Szamossy Elek és Ormos barátsága még Olaszországban kezdődött, amikor Szamossy, követve bécsi mestere Karl Rahl ${ }^{160}$ tanácsait, Velencébe és Rómába ment tanulmányozni a nagy olasz festők müveit. Ormos ebben az időpontban szintén Velencében tartózkodott. ${ }^{161}$ Ennek a barátságnak köszönhetően Ormos Szamossyval együtt Munkácsyt is meghívta birtokára, Buziásra. Munkácsy nekik köszönhetően első ízben találkozhatott nagy európai festők műveinek másolataival. ${ }^{162}$ Minderről Munkácsy önéletrajzi írásában is megemlékezik. ${ }^{163,164}$

\footnotetext{
${ }^{159}$ Ormos Zsigmond (1813-1894). Mügyüjtő, müvészettörténész. Zádor Anna ed.(1962), 220.o.

${ }^{160}$ Lyka (1942), 112.o.

${ }^{161}$ Országos Széchényi Könyvtár-Kézirattár. Levelestár. Ormos Zsigmond Pesty Frigyesnek:Berlin
} augusztus 20 kán 1858., 1858-1884. é. n.

${ }^{162}$ Munkácsy (1950), 68.o.

${ }^{163}$ Munkácsy (1950), 68.o. : „Tizenöt, tizenhat hónapja voltam már Szamossynál, amikor öt Ormos barátja, aki müpártoló esztétikus és író volt egyszemélyben meghívta magához látogatóba. Ormos is Gyulán élt, mikor én még nagybátyjámnál voltam, s néhányszor látott Szamossynál. Sőt azt is tudta, hogy azóta sem váltam el tőle. Meghívott hát engem is [...] Összepakoltunk s elutaztunk egy kies, kis fürdőhelyre: Buziásra, ahol nagyon kellemes heteket töltöttem.[...] élvezettel hallgattam mikor Szamossyval a müvészetröl beszélgettek. [...] Legszívesebben a régi, nagy mesterekről beszélgetett, annál is inkább mert értékes gyüjteménye volt. Ök ketten tudták, hogy a képeket milyen szemmel kell nézni s a festés technikájáról vitatkoztak. Nekem mindez újság volt, de tanulságos, hasznos újság. [...]

Mesélgettek a híres olasz remekekről s megmutatták a legnevezetesebb alkotások rézmetszeteit.Igy ismerkedtem meg a nagy mesterekkel, s azóta sem ismerem öket máskép pedig Velencében is, Rómában is jártam mielőtt Párizsba mentem. Egyszer Ormos Rafael valamelyik vázlatát mutatta, s így szólt: Remélhetöleg te is festesz majd ilyesvalamit... Csak gondosabban dolgozd ki, mint ez itt ...Sajnos sohasem teljesítettem házigazdám óhajtását. Az én vásznaim vázlatok“

${ }^{164}$ Munkácsy (1950), 70.o. : „Ormos társaságában teljesen kinyilt a szemem, s éreztem, hogy az akadémián van a helyem. [...] Elbúcsúztam a derék Szamossytól. Nagyon érzékeny volt a búcsú. Hiszen még most is nagyon hálás vagyok neki a sok jóért amelyben részesített. Az élet hívott s nem tudtam ellenállni. Meg kell kezdenem a munkát-gondoltam-nem fontos, hogy mi lesz a vége...“ 
„Ormos társaságában teljesen kinyílt a szemem, s éreztem, hogy az akadémián van a helyem.“165 Ennek elsősorban az anyagi vonzatait kellett megteremteni, így Munkácsy 1863 őszén Pestre utazott. Itt Szamossy jóvoltából, illetve annak baráti körének köszönhetően müvészi útkeresése megfelelő keretek közé került. Pest városa az 1860-as években már két művészeti egyesülettel büszkélkedhetett. (Pesti Müegylet,1840 ; Képzőművészeti Társulat, 1861) A Pesti Müegylet megalapítása azon túl, hogy a látogató közönséghez igyekezett közelebb hozni a müvészetet, annakízlését is formálta. Kiállításaikon külföldi, zömmel osztrák festők munkáit is szerepeltették. 1853-tól ezek a kiállítások állandóvá váltak. ${ }^{166} \mathrm{Az}$ akkori magyar müvészetet alakító, formáló művészek ezen egyletnek köszönhetően intézményesített pártfogóra találtak. A Képzőművészeti Társulat taglétszáma évről-évre gyarapodott, amiben nagy szerepet játszott az a körülmény, hogy az egylet vezetői is gyakorló magyar művészek voltak. Ennek köszönhetően a saját bőrükön érzékelték a magyar müvészélet nehéségeit. Alapítása ugyanarra az időre esett, mint az egyik osztrák művészeti egyesületéé (,Genossenschaft”, 1861). ${ }^{167}$

Munkácsy pesti tartózkodása alatt az egyesület (Képzőművészeti Társulat) több festményének az eladását segítette elő. Témaválasztásában ugyanakkor ráirányította a fiatal művész figyelmét a vásárlói kör igényeire. A pesti magyar müvészek közül legnagyobb hatással az ún. Rahlianerek, Szamossy egykori bécsi iskolatársai voltak. Az egyesület titkára, Harsányi Pál ugyancsak a pártfogásába vette Munkácsy Mihályt. A Képzőművészeti Társulatnak köszönhetően Munkácsy első ízben szerepelt egy hivatalos művészeti kiállításon a „Hazatért és elbeszélő honvéd“ című festményével, majd pártfogásának köszönhetően havonta 10-15ft támogatásban is részesült, kiállításait pedig ingyenesen látogathatta. ${ }^{168}$

\footnotetext{
${ }^{165}$ Munkácsy (1950), 70.o.

${ }^{166}$ Lyka Károly (1942), Nemzeti Romantika. 20. o.

${ }^{167}$ Schaeffer (1917), 7.o.

168 Lyka (1942), 24. o. : ,[...] rövid idő mulva egy olajfestményt hozott, a „Hazatért és elbeszélő honvédet“", melyet én megtekintvén, meglepve láttam, hogy oly kevés tanulás után, mint amennyiben ő eddig asztaloskodása mellett részesült, már ily müterméket tud, még pedig oly rövid idö alatt előállítani.
} 


\section{Bécs és Karl Rahl szerepe}

\subsection{A Bécsi Képzőmüvészeti Akadémia és Karl Rahl magániskolája}

Miután Munkácsynak sikerült összegyüjtenie a Bécsi Képzőmüvészeti Akadémia előkészítő évfolyamára a megfelelő összegű tandíjat, a birodalom fővárosába utazott. Választásában nagy szerepe volt a pesti Rahlianereknek és Karl Rahl nagy tekintélyének. Nevesítve a Rahlianereket a következő lista állítható fel: Szamossy Elek, Than Mór, Lotz Károly, valamint nagy tisztelője, Ligeti Antal.

Rahl egykori bécsi magániskolájának tanítványai megkülönböztetve magukat a Bécsi Múvészeti Akadémia, illetve Ferdinand Waldmüller magániskolájának diákjaitól magukat Rahlianereknek nevezték el. Magyar tanítványainak köszönhetően beszélhetünk első ízben a nyugat-európai müvészet színvonalán alkotó magyar élvonalbeli festőművészekről. Than Mórnak és Lotz Károlynak köszönhetően honosodhatott meg a történelmi és mitológiai tárgyú monumentális falképfestészet Magyarországon. ${ }^{169}$ Már nem olyan elszigetelten élő magyar művészekről beszélhetünk, mint az Angliában nagy hírnévnek örvendő Brodszky Károly ${ }^{170}$ vagy a Firenzében alkotó Markó Károly. Egy magyar földön munkálkodó, alkalmanként külföldön megbízásokat teljesítő kisebb csoportról volt szó, akik bécsi tanulmányaiknak, tanáruknak, Rahlnak köszönhetően barátságot ápoltak egymással. Rahl professzor hatása Munkácsyt Rahl fent megnevezett tanítványain keresztül már Munkácsi bécsi

\footnotetext{
Bemutatván azt a legközelebbi választmányi ülésben s a juryhez megbírálásra kiadatván, az kétségtelen tehetséget bizonyítónak jelentette ki.“

${ }^{169}$ Szvoboda Dománszky Gabriella (1986), A budapesti falképfestészet vázlatos áttekintése (1803-1903). Müvészettörténeti Értesítő, 1986., 3-4. szám. 133-172.o.

${ }^{170}$ Brodszky Károly (1807-1855), Magyar festő. In: Zádor Anna ed. (1962), Magyarországi művészet a XIX. század első felében. A nemzeti müvészet kezdetei. 104.o.
} 
tartozkodása elött megérintette. Rahl neve nemcsak a magyar müvészek körében, hanem munkáinak köszönhetően a magyar arisztokrata körökben sem csengett ismeretlenül. ${ }^{171,172}$ Alakja összefonódott a nemzeti kultúra ápolásával is, hiszen a forradalmi időkben bécsi egyetemi parlamenti képviselő volt és a negyvennyolcas múlt egészen élete végéig kisértette. Nem csoda, hogy a nemzeti kultúra ápolásának egyik lelkes támogatójává vált. Forradalmi múltjának és forradalmian új tanítási metódusának köszönhetően a Bécsi Akadémia mellözöttjévé és a magyar Bécsben müvészetet tanulni szándékozó, irredenta gondolatokkal, helyenként múlttal rendelkező fiatalok közkedvelt professzora volt.

\subsubsection{Karl Rahl szerepe a magyar és osztrák múvészetben}

Karl Rahl Munkácsy Mihályról szóló, Magyarországon megjelent legújabb monográfiájában nagyon csekély szerepet kapott. ${ }^{173} \mathrm{~A}$ bécsi professzor vagy hamis tényekkel, vagy fontosságának hangsúlyozása nélkül szerepel. ${ }^{174}$ A Bécsi

\footnotetext{
${ }^{171}$ Lyka (1942), 50. o.: ,[...] az ötvenes években szinte tucatszámra festette mágnásainkat, így Andrássy Manót, Podmaniczky Frigyest, Pejacsevics Frigyest és feleségét, stb., de festette Liszt Ferencet is.“

${ }^{172}$ Malonyai Dezső (1898), 73.o.: „Az osztrák mesterek nevei közül a legjobban hangzó volt akkor nálunk a Rahl Károlyé, ki a mint megfordult Pesten, özönnel kapta az arcképmegrendeléseket. Bécsbe járóbb föuraink csinálták neki itthon a renomét, melyre ö nem is volt méltatlan. A mi müvészeink közül is többen nála tanultak.“

${ }^{173}$ Bakó Zsuzsanna (2012), Munkácsy. 10.o.

${ }^{174}$ Malonyai (1898), Ilges (1899), Lyka Károly (1964), Munkácsy 1844-1900, A Müvészet Kiskönyvtára. Képzömüvészeti Alap Kiadóvállalata, Budapest., Perneczky (1970), Végvári Lajos (1961), Munkácsy. Corvina, Budapest, Székely András (1977), Mihály Munkácsy. Mit siebzehn farbigen Tafeln und dreißig einfarbigen Abbildungen, Henschelverlag- Berlin, Corvina -Budapest, Arkady-Warsawa, Székely András (1979) Munkácsy. Corvina Kiadó, Budapest., Végvári Lajos, (1983), Munkácsy Mihály 1844-1900. Képzömüvészeti Kiadó, Budapest., Rózsaffy Dezső (1934), Forschungsinstitut für Kunstgeschichte der Ungarischen Akademie der Wissenschaften MDK-C-I-13/140,1. Rózsaffy : Munkácsi élete és müvészete címü elöadás kézirata. 13/144 1-50. Munkácsy Mihály élete és müvészete. Bakó Zsuzsanna (2012), Munkácsy.
} 
Képzőmüvészeti Akadémia levéltárában végzett kutatómunkámnak köszönhetően derült fény arra, hogy Karl Rahl a Bécsi Képzőművészeti Akadémián nem volt Munkácsy Mihály professzora. ${ }^{175}$ A téves feltételezé azon az egyszerü tényen alapulhatott, hogy Munkácsyra a bécsi mester nagyobb hatást gyakorolt, mint az akadémián müködő professzora, Karl Wurzinger ${ }^{176}$. Hiszen az előkészítő osztály bécsi időszakból származó leveleiben Munkácsy egyetlen alkalommal sem tett róla említést.

Rahl forradalmi múltja és egyéni tanítási metódusa miatt más úton közelített a művészettörténethez, a hangsúlyt másra fektette, mint korabeli bécsi professzortársai. Mindez sok konfliktust eredményezett a hivatalos müvészet elkötelezett híveivel. Erről a konfliktusról nyújt képet Rudolf Eitelberger ${ }^{177}$ és a rivális magániskola professzorának, Ferdinand Waldmüllernek ${ }^{178}$ a munkája. A formálódó magyar müvészéletet alkotó művészek névsorát tekintve azonban nem hagyható figyelmen kívül Waldmüller professzor munkássága sem. Tanítványai közül kiemelkedik Zichy Mihály, ${ }^{179}$ aki a cári udvar első számú festője volt. Az 1880-as években a bécsi akadémiáról elutasított professzorok, Karl Rahl és Ferdinand Waldmüller tanítványait a Bécsi Képzőművészeti Akadémia tantestületének professzorai között találjuk. ${ }^{180}$

\subsubsection{Karl Rahl Professzor}

Meglepő módon az osztrák szakirodalom sem bővelkedik monográfiákban Karl Rahl

\footnotetext{
${ }^{175}$ Dr.Bakó Zsuzsanna (1994), Munkácsy Békéscsabán, Zádor Anna ed. (1962), 223. o.

${ }^{176}$ Karl Wurzinger (1817-1883), osztrák festő. A Bécsi Képzőművészeti Akadémia professzora.

${ }^{177}$ Rudolf Eitelberger (1817-1885), müvészettörténész.

${ }^{178}$ Ferdinand Georg Waldmüller (1793-1865), osztrák festő. In: Zádor Anna ed. (1962), 112. o.,496.o.

${ }^{179}$ Zichy Mihály (1827-1906), magyar festő. In: Zádor Anna ed. (1962), 118.o., 497.o. Bényi László-B. Supka Magdolna, (1953) Zichy Mihály, Lyka Károly (1928), Zichy Mihály emlékezete. Budapesti Szemle.

${ }^{180}$ Christian Grieppenkerl és August Eisenmenger.
} 
életéről. Ezért a kutatómunka során kiemelkedő jelentőséget kaptak a Rahl korabeli müvészettörténettel foglalkozó sajtótermékek is.Valamint egykori tanítványának, August George Mayernek ${ }^{181}$ a visszaemlékezései, a tizenkilencedik század nagy tekintélyü német müvészetkritikusának Friedrich Pechtnek $^{182}$ az írásai, ${ }^{183}$ illetve személyes jóbarátjának, a klasszicista stílusú német festővel, Peter von Cornelius-szal ${ }^{184}$ folytatott levelezése is. A korabeli sajtótermékekben napvilágot látott cikkek Franz Hottner írását ${ }^{185}$ használták fel forrásul. Ezek forrásául a professzorral folytatott személyes beszélgetések szolgáltattak alapot. August George Mayer visszaemlékezései azon túl, hogy a professzor magániskolájába és annak mindennapjairól nyújt betekintést, a magyar tanítványokról (Than Mór és Lotz Károly) is megemlékezik, kiemelve Than Mórt, mint Rahl akkori legtehetségesebbnek tartott tanítványát.

Rahl magániskolájának alapítása szinte egy időre esett a már említett Ferdinand Waldmüllerével. Az iskolák életrehívásában nagy szerepet játszott az akkori Bécsi Képzőművészeti Akadémia professzorainak elutasító magatartása, hiszen mindkét művész az Akadémia által nem támogatott vizeken evezett. Rahl a nagy olasz reneszánsz mesterek példáját követve tanítványaival egy nagy családot alkotott. Fontos volt számára a régi mesterek remekmüveinek másolása, ezen keresztül pedig a fiatal művészek technikai tudásának tökéletesítése, szemben az akadémián elfogadott gipszszobrok másolásával. Az olasz reneszánsz festők életteli színeinek alkalmazása pedig ugyancsak ellentétben állt a hivatalosan elfogadott színkezelési módszerekkel. Korának egyik legnagyobb koloristájaként tartották számon. A festmények alapozási technikája szintén nem az akkori modellt követte, hanem Rahl elsajátította a velencei

\footnotetext{
${ }^{181}$ August George Mayer, (1834-1889) Osztrák festő és író. Österreichisches Biographisches Lexikon 1815-1950.,419.o.

${ }^{182}$ Friedrich Pecht, (1814-1903) német festő, műkritikus.

${ }^{183}$ Friedrich, Pecht (1877), Deutsche Künstler im Neunzehnten Jahrhundert. Studien und Erinnerungen. Nördlingen, Beck., Pecht, (1894), Aus Meiner Zeit, Lebenserinnerungen. Verlaganstalt für Kunst und Wissenschaft. Vormals Friedrich Bruckmann. Zweiter Band. München.

${ }^{184}$ Peter von Cornelius (1783-1867), német festö.

${ }^{185}$ Recensionen und Mittheilungen über bildende Kunst (1863), Biographische Skizze von Friedrich Hottner: Carl Rahl. 37. o.
} 
mesterek aláfestési módszerét: a bitumenes eljárást követte. Ezt a fiatal Munkácsy Mihály is megtanulta és egész mủvészeti életútja során ehhez hű maradt. ${ }^{186,187}$ Miután az Akadémia Rahlt eltanácsolta professzorai közül, tanítványaival együtt a bécsi titkosrendőrség célpontjaivá váltak. ${ }^{188}$ Rahl érdeklődése a müvészet iránt már fiatal gyermekkorában megnyilvánult. Édesapja révén, aki rézmetszőként dolgozott, hamar belekóstolhatott a rajz, a színek és a müvészettörténet világába. Érdekes módon abban a bécsi házban ${ }^{189}$ látta meg a napvilágot, ahová ötvenhárom évvel később a fiatal Munkácsy Mihály első ízben költözött. Rahl édesapja, aki professzorként a Bécsi Akadémián dolgozott, több ízben is próbálta fiát eltéríteni a müvészpályától, de sikertelenül. Felismerve annak tehetségét, végül engedett fia kérésének. A fiatal Rahl többek között Michelangelo anatómiai tanulmányait tanulmányozta és egyre pontosabban lerajzolta ezeket. Ezeknek az ismereteknek egy életen át nagy hasznát vette és szeretettel gondolt vissza ezekre az időkre. ${ }^{190}$ Rahl nagyfokú tudásvágya egyébként is már nagyon korán megmutatkozott, hiszen kilenc évesen már Plutarchost olvasott. Az ókor és mitológiája iránti szeretete apai hatásra már gyerekkorában hatalmába

\footnotetext{
${ }^{186}$ Wittman Zsuzsa-Velledits Lajos (1994), Munkácsy Mihály festőtechnikája és anyagai. In: Munkácsy Mihály (1844-1900), Nemzetközi Tudományos Emlékülés. 109-125.o.

${ }^{187}$ Polenyák Ivett (2012), „The Influence of the Venetian Scool on the development of Hungarian painting arts, as intermediated", in: Conference proceedings, International Institute of Social and Economic Sciences, Palermo, Sicily, 2012, április 15-18. ISBN: 978-80-905241-0-1.

${ }^{188}$ August George Mayer (1882), 74.o.: „Es war also durchaus nicht nothwendig, dass sich die Polizei um unser Seelenheil zu kümmern begann und diese dadurch documentirte, dass man die ruhig und höchstens paarweise im Gespräche um die Ecke der Favoritenstraße in die Feldgasse einbiegen Wollenden, wie es gleich in den ersteren Tagen auch mir geschah, dort abfasste und auf s Commissariat in die Schaumburgergasse führte, dort nach einander um Name, Stand, Alter, Religion, Impfzeugniß, Schulunterricht u. s. w. ausfrug, Alles mit großer Ernsthaftigkeit notieő und dann noch nach etwaiger Betheiligung an der vorhergegangenen Bewegung auszuforschen suchte, auch unsere Hüte und Hemdkrägen zu weich fand, uns anrathend: Vatermörder und Cylinder zu tragen, was man damals für ein besonders Attribut loyaler Gesinnung zu halten schien.“
}

${ }^{189} \mathrm{~A}$ bécsi Alservorstadtban a Wickelburggasse-ban 1812. augustus 13-án. : Recensionen und Mittheilungen über bildende Kunst (1863), 37.o.

${ }^{190}$ Pecht (1887), 184-185.o. 
kerítette. ${ }^{191}$ Tehetségének további visszaigazolása volt az a tény, hogy már tizenöt évesen a Bécsi Képzőművészeti Akadémia hallgatója volt. ${ }^{192}$ Az akadémia szabályain túllépve, otthonában önállóan komponált antik történeti és természet utáni rajzokat, de bármit lerajzolt, ami megtetszett neki. ${ }^{193}$

A fiatal Rahl müvészeti útkeresésére nagymértékben rányomta bélyegét az a festő trió $^{194,195}$, amely festményeit a régi velencei iskola színeinek jegyében alkották. Rahl az ő tanításuk hatására korán felismerte, hogy az akadémiai szabályok, amik például a színek használatára vonatkozóan voltak érvényben, idejétmúltak. Ezeknek az akadémiai szabályok alapján kevert színek szöges ellentétben álltak a Rahl és tanárai által használt lángoló, életteli színekkel. ${ }^{196}$ Rahl akadémiai évei alatt szerencséje volt, mert akkori tanára, Redl professzor béketűrően figyelte a tehetséges növendéket. ${ }^{197}$ August George Mayer mestere sajátos karakterét annak tulajdonítja, hogy Rahl a fiatalkorában alkotott legtöbb müvét nem az akadémián, hanem otthon alkotta. Ez az akadémiai tanulmányok

\footnotetext{
${ }^{191}$ Mayer (1882), 1-2.o.

${ }^{192}$ Recensionen und Mittheilungen über bildende Kunst (1863), 38.o.

${ }^{193}$ Mayer (1882), 1-2.o.

${ }^{194}$ Josef Bayer, Maschko, Schwind: Recensionen und Mittheilungen über bildende Kunst (1863), Biographische Skizze von Franz Hottner: Carl Rahl. 38.o.

${ }^{195}$ Moritz von Schwind (1804-1871), osztrák festő.

${ }^{196}$ Mayer (1882), 1-2.o.: „Die hauptsächlichste Satzung für das Malen war: Man dürfe kein Weiß zu den Schatten nehmen, d. h. dieselben nicht mit Deckfarbe nach Bedürfniß aufhellen, sondern nur mit durchsichtigem Braunroth antuschen, die darunter befindliche weiße Leinwand musste dabei ein Uebriges thun."

${ }^{197}$ Mayer (1882), 3.o.: „Der Professor Redl, ein alter Herr, der zu den Originalen damaliger Zeit zählte, [...] lobte die Arbeit. Da fasste sich Rahl ein Herz ein gestand die eigenmächtige Verwendung der Deckfarbe, worauf der Professor sogleich erwiderte: „Ah! Sie, das dürfen Sie nicht thun!“ Später jedoch ließ er es ruhiger geschehen, indem er äußerte: „Zu meiner Zeit hat man es anders gemacht!“ Er erzählte die feststehende Farbenscala auf: „Einen röthlich-braunen Schatten, eine gelblich-graue Mezzotinte, eine röthliche Fleischfarbe und gelbliche Lichter, und das war recht hübsch. Jetzt machen Sö`s anders, ist aber auch recht schön“
} 
befejezése után sem változott, így egész életében megmaradt autodidaktának. ${ }^{198}$ Tehetségének elismeréseként már akadémiai tanulóévei alatt megbízásokkal látták el. ${ }^{199}$ 1831-ben sikeresen pályázott az akadémia által meghírdetett „Reichel'schen Preis“ díjra, amit Dávid Abdulam barlangjában („David in der Höhle Abdulam“) címü képével nyert meg, illetve ezzel együtt egy ösztöndíjat is. Valójában azonban a pozitív elbírálás ellenére sohasem kapta meg azt, ${ }^{200}$ mivel a pályázat elbírálásakor Rahl még nem töltötte be a huszadik életévét. ${ }^{201}$ Példa nélkül állt az akadémia történetében, hogy e díjat valakinek ilyen fiatal korban odaítéljék. ${ }^{202} \mathrm{~A}$ következő évben pedig hiába pályázott, pályázati anyagát elutasították. Ennek indoklása szerint olyan személy nem vehet részt a pályázatban, aki azt már egyszer elnyerte. ${ }^{203,204}$

Rahl konfliktusa a Bécsi Képzőmüvészti Akadémia professzoraival már ebben a korai alkotó időszakában elkezdődött. Látható, hogy ez az ellenséges viszonyulás a fiatal tehetségnek, ${ }^{205}$ egyben annak a festészet terén alkalmazott újszerü látásmódjának volt köszönhető. Ez az ellenséges atmoszféra csak a müvész életútjának végefelé oszlott el.

\footnotetext{
${ }^{198}$ Mayer (1882), 3.o. :,,[...] brachte er [sie] meist vom Hause mit und schöpfte sie zum größten Theile aus sich selbst, und so ward er früh und blieb zeitlebens Autodidakt. Dieser Umstand wird zum Schlüssel vieler seiner Eigenthümlichkeiten, seiner Vorzüge und Mängel“

${ }^{199}$ Recensionen (1863), 38.o. és Pecht (1877), 186.o.: Einer seiner ersten Aufträge bekam er von einer Gesellschaft von Landgeistlichen, die von ihm ein Gemälde von der Madonna bestellte. Nach diesem Auftrag malte er einen heiligen St. Florian für Dorfkirchen, eine Taufe Christis und ein Porträt des Pfarrherrn.

${ }^{200}$ Pecht (1877), 186. o.

${ }^{201}$ Pecht (1877), 186-187. o.

${ }^{202}$ Recensionen (1863), 38.o.

${ }^{203}$ Pecht (1877), 187.o.

${ }^{204}$ Recensionen (1863), 38.o.

${ }^{205}$ Karl Rahl még alig töltötte be a huszonegyedik életévét amikor a Goethe által inspirált „Halász“ címü festményét a Bécsi Müvészegyesület megvásárolta. Ugyancsak ebben az évben a család lakhelyén a József városban szintén nagy elismerésben részesült az egyház részéről, hiszen az ott álló Piarista templom oltárképének megfestésére: „Vermählung Maria“ kapott megbizatást.: Pecht (1877), 187.o.-A müvész neve az ún. Arany könyvben is helyet kapott.
} 
$\mathrm{Az}$ akadémiai évek után megfordult Itália és Németföld több városában. Ezen tanulmányútjai során még több tapasztalatra, ismeretre és életreszóló barátságokra tett szert. ${ }^{206}$ Ekkortájban fordult meg első ízben a Magyar Királyság területén is. Az ország kultúrája rabul ejtette a festőt. A magyar arisztokraták körében pedig nagyon kedvelt portréfestő lett és hírnevének köszönhetően Debrecen városa is megbízást adott számára a „Szent Anna“ és a „Mihály főangyal (Erzengel Michael) ${ }^{207}$ megfestésére. A magyar nép karaktere, kultúrája mellett a cigányság misztikus világa is megmozgatta a festő fantáziáját. ${ }^{208,209}$ Bécsbe visszatért, majd Rómába utazott, ahol 18 évet töltött. Ezen időszak alatt tanulmányozta és másolta a velencei iskola mestereinek remekmüveit, azok színkezelési technikáját. Müvészetében a természet egyre nagyobb hangsúlyt kapott. A velencei iskola aláfestési módjának köszönhetően (,grau in grau“) a vászonra felvitt színek élettelibbek lettek. Tizennyolc év elteltével Bécsben megfestett „Manfred‘s Einzug in Luceria“ címü történelmi festményének az akadémia részéről történt ellenséges fogadtatása miatt visszatért Rómába és egészen 1843-ig, édesapja haláláig nem tért vissza Bécsbe. ${ }^{210}$ A bécsi arisztokrata családok azonban az akadémia professzorainak negatív véleménye ellenére is szívesen látták szalonjaikban a világot látott, művelt festőt, és portré megbízásokkal halmozták el. Rahl számára így megteremtődtek egy európai utazás financiális keretei. Az európai forradalmi megmozdulások már Párizsban találták. Felvilágosult gondolkodó lévén rokonszenvezett ezekkel. Ezek szellemében gyors hazautazása után belépett a bécsi

\footnotetext{
${ }^{206}$ Eberhard Wächter (1762-1852), a német klasszicista festészet egyik képviselője.

${ }^{207}$ Pecht (1877), 190.o.

${ }^{208}$ Nagyváradon egy negatív tapasztalattal is gazdagabb lett, mert a Szent Anna címü festményéért kifizetett 600 Guldenétől megszabadította egy cigánylány.: Pecht (1877), 190.o.

${ }^{209}$ Recensionen (1863), 39.o.

${ }^{210}$ Recensionen (1863), 57.o. :"Die Wiener Akademie erkannte diese Skizzen aber für unbrauchbar zu dem bestimmten Zweck und forderte die Einsendung anderer und ,besserer’ A Bécsi Akadémia elismerte a vázlatait, de felhasználhatatlannak tartotta a megbízás szempontjából és egy másik pályázatot támogatott. Az akkori legationsrater, Kestner azonban Rahl vázlatait az akadémia professzorai elé küldette ujabb elbírálásra, aminek eredményeképpen Rahl egyik vázlatát:,,Manfred`s Einzug in Luceria“ alkalmasnak találták egy másik császári megbízás teljesítésére. Ennek ellenére a kész festmény a Belvedere raktárába került.
} 
akadémiai légióba is. Szónoklatai révén nagy népszerűségre tett szert, így Eisenachban megválasztották az egyetemi parlament szóvívőjének is. Innen Windischgrätz seregei elől Münchenbe utazott, így a bécsi fegyveres összecsapások alatt nem tartózkodott a városban. ${ }^{211}$ Müncheni tartózkodása alatt a korabeli festőnemzedék tagjaival kötött barátságot, akik a későbbiekben nagy hatással voltak hazájuk festészetére, müvészetére. ${ }^{212}$

\subsubsection{A provizórium első hat hónapja a Bécsi Akadémián (1850-1851)}

Az Akadémiát 1848-ban a forradalom miatt bezáratták, majd 1850-ben reorganizálták. Ennek szellemében három új professzor kapott katedrát: Franz Joseph Dobiaschofski, ${ }^{213}$ Hans Gasser és Karl Rahl. Rahl követte nagy itáliai reneszánsz példaképeinek tanítási módszereit ${ }^{214}$, így az akadémia diákjai között gyorsan nagy népszerüségre tett szert. A szabad professzorválasztás is az akadémia újraszervezése jegyében történt, aminek az eredménye Rahl tanítási módszerének a helyességét igazolta. ${ }^{215,216}$

\footnotetext{
${ }^{211}$ Pecht (1877), 198.o.

${ }^{212}$ Pecht (1877), 198.o.: Genelli, Roß, Rottman, Kaulbach, Stange, Schleich, Volz, Spitzweg, Berdellé.

${ }^{213}$ Franz Josef Dobyaschofsky (1818-1867), osztrák festő.

${ }^{214}$ Mayer (1882), 46-47.o.: „Meg kellene tanulni teljes mértékben a természetet utánozni és semmi változtatást nem lenne szabad megengedni. A formák és színek utánonázását kellene megtanulni és gyakorolni! A teremben található jó képeken, egy Bonifazio-n, Tintoretto-n és több Paul Vernoese-n mutatta meg nekünk, milyen alaposan kellene festeni, hogy a müvészi szabadsághoz eljussunk. Csak az alaposan megtanultakat tudja az ember szabadon kifejezni.“ Így fejezte ki Rahl bátran mindenkinek és minden alkalommal a részletektől indulva az általánosig haladva, hogy újra visszatérjen a részletekre, találó megjegyzéseit és meglepően új meglátásait, aminek hatására hamarosan hallgatók tömege vette körül. ‘214

${ }^{215}$ Mayer (1882), 47-48.o. : ,[...] Die Form fand sich von selbst, wir schrieben, und ich gewiß einer der Ersten, Rahl`s Namen weithin sichtbar, ja sogar mehrmals auf Staffelei. Reitzbrett und wo sich sonst noch ein mehr oder weniger geeigneter Raum dazu finden wollte. Es war eine Demonstration und wurde auch
} 
A szabad választások eredményeképpen a mellőzött professzorok felháborodása egészen az akadémiát felügyelő Vallás és Közoktatási Minisztériumig jutott el, aminek eredményeképpen a három új professzort hat hónap elteltével menesztették. Rahl távozásának okairól a következő információk láttak napvilágot: Rahl oktatási metódusa, politikai magatartása volt az, ami miatt az uralkodó körökben nem örvendett nagy népszerüségnek. ${ }^{217}$ Walter Wagner az akadémiai hallgatók minisztériumhoz küldött petíciójáról tesz említést, amit az illetékes minisztérium azzal utasított el, hogy a diákoknak nem volt petícióhoz való joguk. Mindennek eredményeképpen Dobyaschofsky egy utazási ösztöndíj címén távozhatott az intézményből, Rahlnak pedig át kellett adnia mütermének kulcsait Karl von Blaas ${ }^{218}$ professzornak. $^{219}$ Ennek köszönhetően fogtak össze leghüségesebb tanítványai és alakították meg professzoruk beleegyezésével annak magániskoláját. A változásnak az európai új festészeti áramlat volt az oka, hiszen Wilhelm Kaulbach és Buonaventura Genelli ${ }^{220}$ történelmi témájú és erőteljes színkezelésű festményei átírták az európai akadémiák festészeti szabályait. A Bécsi Képzőművészeti Akadémiának sem lehetett ezalól kivétel, bár Rahl rehabilitásának dátuma, 1864, a többi akadémiával szemben nagyfokú megkésettséget mutatott. Mire Rahl a Bécsi Akadémia által is elismert mủvésszé lépett elő, addigra az általa képviselt klasszicista stílust a Karl Piloti neve által fémjelzett történelmi tárgyú als solche aufgesetzt, den Löwentheil trug Rahl davon, umso mehr, als sich die geschlossene Gruppe der Führichaner ebenfalls für Rahl erklärte.“

${ }^{216}$ Mayer (1882), 47-48.o.

${ }^{217}$ Recensionen (1863), 59.o.: „Rahl’s Kunstrichtung und politische Gesinnung war aber in maßgebenden Kreisen nicht genehm.“

${ }^{218}$ Karl von Blaas (1815-1894), osztrák festő. Liezen-Mayer Sándor magyar festő a taníványa volt a Bécsi Akadémián.

${ }^{219}$ Wagner, Walter (1967), Die Geschichte der Akademieder Bildenden Künste in Wien, 153-154.o.: ,[...] De amikor júliusban az elökészítő iskola növendékei sajnálkozásukat fejezték ki egy beadványban amiatt, hogy Rahlt és Dobyaschofskyt állítólag újra el akarják távolítani, noha az Akadémia vezetősége felhívta a figyelmet arra, hogy a Minisztérium hatáskörében álló ügyekben a tanoncoknak nincsen petíciójoguk, mégis továbbította a dolgot a Minisztériumba. Válaszul Dobyaschofski egy külföldi tanulmányi ösztöndïjat kapott és Rahl műhelyének kulcsát Blaas kapta meg.“

${ }^{220}$ Buonaventura Genelli (1798-1868), német festő. 
historikus festészet váltotta fel. Az 1860-as évekbeli bécsi müvészetről nagyon szemléletes képet tár elénk Than Mór 1863-ban íródott publikálatlan levele, amelyben ugyancsak a historikus festészet előtérbe kerüléséről kapunk képet: „Bécsben a müvészeti állapotok azóta sem változtak, kivétel ez alól Rahl tevékenysége, az akadémia professzora, de a közönség és a müvészeti egylet ízlése ugyanaz, és csak azt mondhatom neked, amit az én képeimről mondanak, akadémikusak szép részletekkel(...) és itt Piloti az, akit a legnagyobb művésznek tekintenek. "221

\subsubsection{Karl Rahl legtehetségesebb magyar tanítványai: Than Mór és Lotz Károly}

Rahl magyar tanítványai a nem megfelelő müvészeti tanulási lehetőségek miatt keresték fel a földrajzilag is legközelebb található Bécs városát, annak művészeti akadémiáját, illetve Rahl magániskoláját. Rahl szabad szellemiségü gondolkodását tükrözi könyvtárának katalógusa, amelyben művészeti, irodalmi, történelmi és útikönyveket egyaránt találunk. A felvilágosult, forradalmi gondolatok jelenléte árulkodik Rahl politikai hovatartozásáról tekintve több könyvcímmel is találkozhatunk:

Elsner: Der Befreiungskampf der nordamerikanischen Staaten. (Az észak amerikai államok függetlenségi háborúja) Stuttgart 1835., Miget: Geschichte der französischen Revolution (A francia forradalom története.) Leipzig. 1842., Zimmermann: Geschichte der Bauernkrieger (A parsztfelkelő története) 1856., Lamartine: Geschichte der Girondisten (A zsirondisták története) Leipzig, 1847., Rousseaus Werke (Rousseau művei) Leipzig, $1844 .^{222}$ Rahl könyvtárában a magyar kultúrával kapcsolatos kötet is

\footnotetext{
${ }^{221}$ Wiener Stadt- und Landesbibliothek-Handschriftenabteilung, Mór Thans Briefe an seinen Freund Hottner. I. N. 75963.: ,[...] Die Kunstzustände in Wien seit beinache dieselben, ausgenommen das Rahl zu thun hat, und Professor ist an der Akademie aber der Geschmack beim Publicum und Kunstvereine sind immer derselbe, und ich kann dir sagen, von meinen Bildern sagen immer das academisch sind, mit schönen detailles [...] und Piloti ${ }^{221}$ ist hier überall der großte Künstler."Publikálatlan.

${ }^{222}$ Wiener Stadt- und Landesarchiv.Material des Künstlerhauses. Carl Rahl hagyatéka.
} 
szerepel: Ungarische Dichtungen (Magyar Költemények) von Dux, 8. Pressburg. $18544^{223}$

Rahl politikai gondolkodását tekintve nem csoda, ha magyar, nagyrészt forradalmi szimpátiával rendelkező tanítványait szívesen pártfogolta. Ezek közül kiemelkedik Than Mór, aki már akadémiai tanulmányai előtt is több forradalmi témájú képet festett. ${ }^{224}$ Rahl magániskolájának alapító létszámában magyar tanítványai viszonylag nagy számban képviseltették magukat. A tizenöt tanítványból ugyanis négyen voltak magyar nemzetiségúek: Than Mór, Latkozi, Lotz Károly és Szále István János ${ }^{225}$. Than Mór ${ }^{226}$ és Lotz Károly ${ }^{227}$ szerepének fontossága Munkácsy tanulmányai szempontjából is megkérdőjelezhetetlen.

Than Mór 1851-ben iratkozott be a Bécsi Képzőművészeti Akadémiára. Akadémiai tanulmányai megkezdése elött Barabás Miklós mütermében tanult festeni. Az akadémián Rahl és Dobiaschovsky óráit látogatta, majd professzorai menesztése után Rahl magániskolájához csatlakozott. Mayer Rahlról írt monográfiájában több oldalt szentelt barátjának, Than Mórnak. ${ }^{228}$ Ezen visszaemlékezés szerint, Than és Lotz Rahl professzor legkedvesebb tanítványai voltak. Professzorukhoz füződő viszonyukat

\footnotetext{
${ }^{223}$ Wiener Stadt und Landesarchiv. Carl Rahl hagyatéka.

${ }^{224}$ Than Mór: Die Schlacht von Szolnok (A szolnoki csata), 1849. március 5.-Magyar Nemzeti Múzeum, Mór Than: Buda ostroma, 1849. május 20-21. - Magyar Nemzeti Múzeum, Than Mór: A nagysallói ütközet -Magyar Nemzeti Múzeum, Than Mór: A komáromi-ácsi csata-Magyar Nemzeti Múzeum. Than Mór: A komáromi csata -Magyar Nemzeti Múzeum.

${ }^{225}$ Szále István János (1811-1870), magyar festő. In: Zádor Anna ed. (1962), 100, 126.o.

${ }^{226}$ Than Mór (1828-1899), magyar festő. In: Zádor Anna ed. (1962), 126, 495.o.

${ }^{227}$ Lotz Károly (1833-1904) magyar festő. In: Zádor Anna ed. (1962), 77, 136, 491.o.

${ }^{228}$ Mayer (1882), 70-71.o.: „Als wir ihn kennen lernten, zeichnete er ganz still und bescheiden an der Akademie Act, daheim aber malte er ein großes Bild „Attila`s Gastmahl“ voll reicher Details. Er erklärte sich sofort für den Eintritt in die Rahl - Schule. Ich erinnere mich, wie Rahl, Skizzenbücher aus Thann`s Dilettanten-Zeit ansehend, sich erstaunt äußerte über den merkwürdigen Umstand, dass Thann schon ein Bild zu gestalten vermochte, die Köpfe aber nicht zum Besten gerathen wollten.“
} 
Mayer visszaemlékezéseiben Szókratészhez és tanítványaihoz hasonlította. ${ }^{229}$ A tanítványok mesterükhöz és egymáshoz való viszonya az iskolát elhagyva is szoros maradt. Jó példa erre Than Mór Hoffmann nevü festő barátjához íródott levele, melyben név szerint kérdezett rá barátai sorsára. ${ }^{230}$ Rahl Than Mórt egyik legtehetségesebb tanítványának tartotta. Mayer visszaemlékezésében kiemeli, hogy Karl Rahlt egyetlen egyszer látta elérzékenyülni: amikor Than Mórt önálló festővé avatta. Búcsúbeszédében egyik legtehetségesebb tanítványának nevezte.“231 Lotz Károlyról ugyancsak elismerően ír Mayer, akit a magyar Pettenkofenként ${ }^{232}$ aposztrofált. $^{233}$

\footnotetext{
${ }^{229}$ Mayer (1882), 102-103.o.: „Es war eine jener traulichen Plauderstunden, welche Rahl mit einigen ihm näher stehenden wertheren Schülern so gerne $\mathrm{zu}$ halten pflegte, nachdem die eigentlichen Unterrichtsstunden vorüber und sich das tumultuirende Gros bereits verlaufen hatte. Da kam er wieder herüber und sprach mit uns, oft stehenden Fußes, meistens aber auf einem Stockerl sitzend, stundenlang über alles Mögliche, vom Nächstliegenden ausgehend, vom harmlosesten Scherz, bis zu den höchsten und ernsthaftesten Problemen, in zwangloser Weise. So mochte ich mir Sokrates und seine Schüler denken!“

${ }^{230}$ Wiener Stadt- und Landesbibliothek, Mór Than: Briefe. I.N. 75967. Than Mór levele Hoffmanhoz. I.N. 75.75966. Mór Than seinem Freund I. N. 75965. Mór Than an seinen Freund. :“ [...] Wie weit sind Gripenkerl und Bitterlich gerne möchte ich von Ihnen auch etwas hören,- sei so gut, und grüsse Sie von mir, und erzähle was ich alles seine dir geschrieben habe.[...] Grüße auf Mayer, Eisenmenger, Gaul\& und schreibe mir etwas über Eure Theme und Wirken."Pest am 24 Sept 1866.
}

Than Mór levele barátjához-Mór Than an seinen Freund. I. N. 75961. „[...] Grüße mir freundlichst Hansen, Eisenmenger, Gripenkerl, Bitterlich und Mayer Chr.-und sage dem (?), daß ich sehr Neugierig bin etwas von Ihnen zu hören, dass seit von Ihre Werken.[...] Engel ist noch im Pest wegen der Széchenyi Monument.,,

${ }^{231}$ Mayer (1882), 134-135.o: „Im Prater, bei Grandauer, waren wir zu Thann`s Abschiedfeier beisammen. Rahl hielt dem scheidenden, ihm sehr lieben, nun zum selbständigen Meister Gewordenen eine Ansprache, wobei seine Stimme von Rührung zitterte und sich Thränen in das Auge drängten, so dass er mehr abbrechend als endigend sich setzte und dem Chorus überließ, mit allgemeinen Hoch! Einfallend die Gläser klingen zu lassen. Rahl war noch eine Weile ergriffen und ich auch. Ich hatte Rahl weinen gesehen! Was ich kaum glauben konnte, und ich beneidete Thann aufrichtig um diese Auszeichnung. Auch der liebenswürdige bescheidene Mori wollte nicht glauben, dass er solche Ehre verdient habe.“

${ }^{232}$ August Pettenkofen (1822-1889), osztrák festő. In: Zádor Anna ed. (1962), 115-116.o.

${ }^{233}$ Mayer (1882), 71.o.: „Carl Lotz ist ein Talent ersten Ranges, von seltenem Umfang. Er würde der ungarische Pettenkofen geworden sein, so seine Stimmungsbildchen malte er. Charakteristisch war die 
Rahl magániskolájából való távozásuk után a professzor egy-egy nagyobb megrendelésének köszönhetően többször juttatta munkához magyar tanítványait is, amiről leveleiben Than Mór is többször tett említést. ${ }^{234}$ A bécsiek idegenül szemlélték az akadémiáról távozott s Rahl magániskoláját látogató fiatal festőnövendékeket. Ellenszenvüket az is táplálta, hogy gyakran dolgoztak együtt női modellekkel. A bécsi titkosrendőrség aktát vezetett az iskola müködéséről, amelyet valószínüleg Rahl rehabilitációja során megsemmisítettek, ugyanis az államrendőrség iratai között annak az akta nevének megnevezésén kívül nincs nyoma. Than Mórral kapcsolatosan azonban fellelhető egy neve alatt szerepelő ezidáig publikálatlan titkos akta. ${ }^{235}$ Mindez Mayer állítását is alátámasztja. Munkácsy Mihályról azonban nem található titkosrendőrségi akta. Az 1860-as években Rahlt rehabilitálták és ismét a Bécsi Képzőművészeti Akadémián taníthatott.

nationale Staffage auf seinen Pußtabildern, deren Reiz er wie sein Zweiter wiederzugeben verstand, aber höhere Ergeiz ließ ihm sich dem griechischen Style zuwenden, was ihm auch vorzüglich gelang. Er malte Fresken für Rahl und später mit Than gemeinsam vollendete er die Ausschmückung des Museums, der Redoute und des Staatsgymnasiums und viele Privataufträge in Pest. In Homburg geboren, ist er durch den Aufenthalt bei der Familie seiner in Ungarn geborenen Mutter zum Ungar geworden. Alle Gaben reichlich, nur kein Glück, kein materieller Erfolg ward ihm zugemessen, er blieb fast verborgen, trotz seines seltenen Genius. Rahl erwähnt seiner in diesem Sinne in dem Briefe an mich.“

${ }^{234}$ Than Mór levele Hoffmanhoz. I. N. 75962. Wiener Stadt- und Landesbibliothek. Handschriftabteilung: „[...] Beim Rahl arbeiten Eisenmenger, den er Stückweise zahlt, dem Bitterlich der 100 Gl. monatlich bekommt und Grippenkerl, der immer (?) für sich arbeitet. Otto ist beim Zimmermann in der Academie, Gaul macht Porträts ich habe aber keinen von beiden ehrsehen.“

${ }^{235}$ HHStA: Informationsbüro, BM. Akten. 6059/1862., Pest,: , ,[...] Than Moritz 35 éves, egy római nő a felesége, történelmi tartalmú festményeket fest, Rómaban tanult és jó ,szakmai híre van. Morális szempontból teljesen fedhetetlen. Titkos politikai kapcsolatai miatt Bécsben megvádolták és bírósági vizsgálatot indítottak ellene, aminek a kimenetele nem ismert. Azóta elsősorban Pesten tartózkodik. [...]“ 


\subsection{Karl Rahl utolsó magyar tanítványa: Munkácsy Mihály}

\subsubsection{Rahl professzor tanításainak hatása Munkácsy Mihályra}

Szamossy Elek mütermében Munkácsy Mihály a festővel kötött barátságán keresztül a magyar festészeti és kultúrális világgal került közvetett kapcsolatba. Szamossy maga is egykori Rahl tanítvány volt, ${ }^{236}$, de egy év leforgása után követve mestere fiatalkori példáját Itáliába utazott. Több olasz város képtárában tanulmányozta a reneszánsz festők nagy mestermüveit. Velencében való tartózkodásáról barátjának, Ormos Zsigmondnak ezidáig publikálatlan leveléböl is tudomást szerezhetünk, aki művészettörténészként és kritikusként ugyancsak nagy hatást gyakorolt a fiatal Munkácsyra. $^{237}$ Mivel Szamossy Elek soha nem látogatott egyetlen egy európai akadémiát sem, csupán Karl Rahl magániskoláját, annak tanítási metódusát alkalmazta a fiatal Munkácsy képzésében. E régi klasszikus módszernek köszönhetően Munkácsy hallás után ismerkedhetett meg a müvészettörténettel, történelemmel, nyelvtannal, mitológiával a rajz és a festés mellett. Ahogy Rahl, úgy Szamossy is nagy hangsúlyt fektetett a természet után és a természetben való rajzra, festészetre. Az anatómia ugyancsak fontos szerepet játszott a festőnövendék oktatásában. Maga Munkácsy erről a klasszikus tanítási módszerről, valamint a Szamossyval való megismerkedéséről

\footnotetext{
${ }^{236}$ Lyka (1942), 112.o.

${ }^{237}$ Országos Széchényi Könyvtár-Kézirattár. Levelestár. Ormos Zsigmond Pesty Frigyeshez, 1858-1884, é. n. (Berlin augusztus 20 kán 1858.): „[...] a lapokat ne ide, hanem ujra csak Velenczébe küldeni sziveskedjék, lakásomat S. Silvestro Campiello Curnis No. 992. semdo piano, - a borítékra mindég ráirva, mert különben a levélhordó megnem fogna találni. Ahogy oda küldött, ezután oda küldemdö lapjai elvesznének ott nem lételem miatt, azt ne hidje Ön, mert távollételem azokat Szamossy Elek nevezetü derék festö hazánkfia, három év ota velenczei lakos, veszi át ki bizonyosan szint oly szívesen futja át a hirlapot, minövel én az ott talált példányokat Velenczébe érkezésemkor átfutottam.”
} 
önéletrajzában részletesen ír. ${ }^{238,239,240,241}$ Többek között felsorolja azokat a nagy itáliai festőket, akiket Szamossy, akárcsak Rahl, színkezelésük miatt a fiatalember figyelmébe ajánlott: Tizian, Veronese, Michelangelo. ${ }^{242}$

Ha Munkácsy visszaemlékezésének német, magyar és az eredeti francia nyelvű kiadását összehasonlítjuk, érdekes különbséget lehet megfigyelni. Amíg a magyar verzióban az a mondat olvasható, hogy: „(...) mesélgetett nekem híres festőkről, Tizianról, Veroneseről, Michel Angeloról és arról, hogy van egy úgynevezett festőmüvészeti

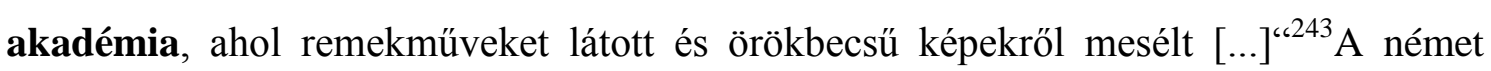

\footnotetext{
${ }^{238}$ Munkácsy (1950), 60-61.o. „Elmeséltem neki, hogy hetenkint háromszor jövök Fischer mesterhez, de szívesen itt maradnék akár örökre is. Úgylátszik az idegent érdekelni kezdte a dolog. Alaposan kikérdezett minden felöl, aztán meghívott, hogy menjek el hozzá s vigyem el a rajzaimat.Nem vártam sokáig, hamarosan felkerestem. A hónom alá szedtem munkáimat és a kastélyba siettem, ahol éppen munka közben találtam. [...] A mester láthatóan örült jövetelemnek megnézte a rajzaimat és kijelentette, hogy bármikor szívesen lát, csak jöjjek el hozzá és dolgozzam nála. Képzelhetik örömömet! [...] Mialatt festegetett, eddigi életemröl meséltem neki és bevallottam félelmemet, hogy vissza kell mennem az asztalosmühelybe.“

${ }^{239}$ Munkácsy (1950), 63-64.o. „Reggel öttöl nyolcig történelmet, nyelvtant és mitológiát tanultam mindenböl egy keveset. Nyolc órától tizenkettöig természet után vagy gipszfigurákat rajzoltam. Délután anatómiával foglalkoztam és estefelé tervezgettem.“

${ }^{240}$ Munkácsy (1897), Souvenirs-Munkácsy: Souvenirs. L enfance. Paris, 109.o.

${ }^{241}$ Munkácsy (1950), 64.o.: [...] Szamossy igazán szeretett nemcsak festeni tanított, de nevelt is. Müvelt ember volt, s szomorúan látta, hogy én mennyire tudatlan vagyok.Igy aztán igyekezett fogyatékos képzettségemet kipótolni. Minden napra adott fel leckét s ha este otthon maradt: mesélni kezdett a történelemböl és írásbeli dolgozataimat javítgatta. Egyszóval arra törekedett, hogy ha nem is nagy de általános müveltségem legyen.“
}

${ }^{242}$ Munkácsy (1950), 63.o.: ,,[...]Természetesen azt nem is sejtettem hogy mi lesz belölem, milyen festö leszek. Csak festö akartam lenni, aki dolgozhat.Ez volt egyetlen kívánságom.Müvészi törekvésem nem terjedt túl azon, amit eddig láttam a nagy terem, ahol mesterem másolta a képeket. Szamossy ugyan gyakran mesélgetett nekem híres festökröl, Tizianról, Veroneseröl, Michel Angeloról és arról hogy van egy úgynevezettfestömüvészeti akadémia, ahol remekmüveket látott és örökbecsü képekröl mesélt [...]“

${ }^{243}$ Munkácsy (1950), 63.o. 
fordításban a következő olvasható: "244 "Szamossy híres festőkről beszélt nekem, elmesélte, hogy olyan festők éltek, mint Titian, Veronese, Michel Angelo, hogy olyan akadémiák léteznek, ahol hasznos dolgokat lehet tanulni, egy atelier-ről (müteremről) is beszélt, ahol csodás munkákat látott. ${ }^{245} \mathrm{Ha}$ a két fordítást összehasonlítjuk, akkor szembeötlő az a lényeges különbség, hogy amíg a magyar fordító egy művészeti akadémiáról, addig a német verzió, akár csak az eredeti, francia műteremről ír. ${ }^{246}$ Szamossy életútját tekintve akadémiai képzésről nem beszélhetünk ${ }^{247}$, de Rahl müterméről, ami egyben magániskolaként is szolgált igen. Az eredetileg franciául írt mü, majd az ezzel megegyező német fordítás felel meg a valóságnak. A magyar fordításban valamilyen okból szövegtorzítás következett be. ${ }^{248}$ A Munkácsy monográfiák nem taglalják Karl Rahl és Szamossy Elek kapcsolatát. ${ }^{249}$ A szerző cikkében $^{250}$ viszont fény derül erre a kapcsolatra. Tény, hogy Szamossy Rahl mütermében tanult és a régi korok mestermüveit galériákban (például Itáliában) láthatta. Ezen művek másolásával igyekezett festészeti ismereteit kibővíteni. Rahl műterme

\footnotetext{
${ }^{244}$ Munkácsy (1897), 104.o.: „Szamossy sprach mir zwar von berühmten Malern, er erzählt mir, daß einstens Titian, Veronese, Michel Angelo gelebt hätten, daß es Maler - Akademien gäbe, auf denen man viel Nützliches lernen könnte, er sprach von einem Atelier, wo er Wunderwerke gesehen hatte [...]“

${ }^{245}$ Munkácsy (1897), 104.o.

${ }^{246}$ Munkácsy (1897)

${ }^{247}$ August George Mayer említi Szamossy nevét az egykori Rahlianerek között, akik az alapító tagjai voltak a professzor magániskolájának. Egyikük sem tanult tovább a Bécsi Képzőművészeti Akadémián, miután Karl Rahlnak ott kellett hagynia akadémiai katedráját. Nem helytálló az a közlése a művészettörténeti szakirodalomnak, hogy végzett akadémiai festő volt: In: Bakó Zsuzsanna (2008), Munkácsy Mihály, 8.o. Magyar Nemzeti Galéria, Kossuth Kiadó, Budapest,In: Zádor Anna ed. (1962) 220.o.,

${ }^{248}$ A kutatómunka során az is kiderült, hogy több esetben is követtek el szövegcsonkítást. Munkácsy eredeti, francia nyelven megírt visszaemlékezésében megemlítette nagybátyja második házasságát, de a magyar fordító ezt a közlését az írónak kihagyta a szövegből.

${ }^{249}$ Malonyai (1898), Ilges(1899), Lyka (1964), Perneczky (1970), 8.o., Végvári (1961), 6.o., Székely (1977), 8.o., Székely (1979), Munkácsy. 6.o., Végvári (1983), 18.o., Rózsaffy (1934)

${ }^{250}$ Strausz Péter-Zachar Péter Krisztián (Ed.) (2011), Történelmi Emlékezet és Identitás. Polenyák Ivett: Munkácsy Mihály és Carl Rahl kapcsolata, (1865). 128-144.o.
} 
összeolvadt magániskolájával, ahol Szamossy is tanult. ${ }^{251}$ Tanítványai névsorában Szamossy Elek neve is szerepel. ${ }^{252}$

Mayer visszaemlékezésében többször megemlékezik arról, hogy professzora festményei előtt tanítványai őszinte csodálattal álltak. Munkájában több festményéről megemlékezik, kiemelve például a „Boreus“címűt, amely alakjaival, színhasználatával mély benyomást gyakorolt rá. 1874-ben Tropauban látta azt viszont. ${ }^{253}$ A Rahltól Szamossy által is elsajátított klasszikus oktatási módszer keretében Munkácsy Mihálynak sikerült pótolnia későbbi akadémiai tanulótársaival szembeni esetleges tudásbeli hiányosságait. A fiatal festőnövendék nem járt gimnáziumba, de a Bécsi Képzőmüvészeti Akadémiára jelentkezve beiratkozási papírján fel kellett tüntetni a legmagasabb fokú iskolai végzettségét. Munkácsy egy pesti gimnázium által kiállított tanúsítvány szerint annak második osztályának szintjét teljesítette. ${ }^{254}$ Ennek a bizonyítványnak a kiállítása, egyrészt Munkácsy akadémiai tanulmányai megkezdéséhez volt szükséges, másrészt Munkácsy tudásának szintjéről kellet számot adnia nagybátyja, Reök István előtt is. A Munkácsy monográfiák állításával ellentétben a festő tudása nem volt alacsony szinten. ${ }^{255} \mathrm{Ez}$ a bécsi, 1864-1865-ös beiratkozási papírokon is szerepel. ${ }^{256} \mathrm{Az}$ eddig megjelent Munkácsyról szóló monográfiák dokumentum hiányában nem tudták bizonyítani, hogy a festő valóban a Bécsi Képzőművészeti Akadémián tanult. Fleischer Gyula munkájában (1935!) ugyan felsorolja a Bécsi Képzőművészeti Akadémián tanult magyar hallgatók nevét, amiben

\footnotetext{
${ }^{251}$ Mayer (1882), 69-70.o.

${ }^{252}$ Mayer (1882), 70.o.

${ }^{253}$ Mayer (1882), 118.o.: „In Rahl’s neuem Atelier stand zuerst der noch aus München stammende „Boreus“ vor unseren erstaunten Blicken. Das Bild machte einen tiefen Eindruck auf mich. Die poetische Farbenstimmung entzückte mich geradezu, und hat nichts eingebüßt von ihrem Reiz, als ich es zuletzt im Jahre 1874 in Troppau wiedersah [...].“

${ }^{254}$ Végvári (1983), 50.o.

${ }^{255}$ Malonyai (1898), 63.o.

${ }^{256}$ Universitätsarchiv der Akademie der bildenden Künste Wien.-Matrikel der im Studienjahr 1863/64 in der Meister- u.Vorbereitungsschuler für Maler, Bildhauer in der in der Architektur, Landschafts, Schule für kleinere Plastik, und Kupfersteherschule auf genommenen Zöglinge.
} 
Munkácsy neve is szerepel, de professzoraik nevének feltüntetése nélkül. ${ }^{257} \mathrm{E}$ dolgozatban szerepel előszőr az a hivatalos dokumentum, amiben többek között a Munkácsyt oktató professzor Karl Wurzinger neve is megtalálható. Munkácsy, „Lieb Michael Leo“-ként, valóban a Bécsi Képzőmüvézeti Akadémia előkészítő osztályát látogatta. A létező monográfiák közül azonban kiemelkedő F. Walter Ilges munkája, amiről a magyar nyelvű Munkácsy monográfiák szerzői gyakran csak a képanyaga miatt tettek említést. Egyedül F. Walter Ilges hangsúlyozza monográfiájában Szamossy és Munkácsy kapcsolatát. ${ }^{258,259}$ Kiemeli, hogy Szamossy fontosnak tartotta, akárcsak Rahl, hogy tanítványai szabadon, szinte korlátok nélkül sajátíthassák el müvészeti ismereteiket, ahogy ezt a nagy klasszikusuk tanítói is tették. Ilges monográfiája azért tölt be különösen fontos helyet, mert nagy része még a Munkácsyval folytatott személyes beszélgetések alapján készült. Maga Munkácsy Mihály Szamossy tanításaira visszaemlékezve elsimerő szavakkal méltataja első mesterét. ${ }^{260}$ Munkácsy szavai Szamossy Elek emberi és tanítói jelentőségét kellőképpen megvilágítják és alátámasztják a jelen dolgozatban Karl Rahl és magyar tanítványainak Munkácsy életútjában.

\footnotetext{
${ }^{257}$ Fleischer Gyula (1935), Magyarok a Bécsi Képzömüvészeti Akadémián., Szögi és Kiss (2003) Magyarországi diákok a bécsi egyetemeken és akadémiákon. 1849-1867.

${ }^{258}$ Ilges (1899), 25.o.: „Es ist wirklich interessant zu sehen, dass wie gerade durch Szamossys Unterricht und seine Methode das Selbstvertrauen des jungen Künstlers gefestigt wurde. Spielend überwand er die schwierigsten Hindernisse, weil sie ihm leicht erschienen."

„[...] Szamossy nem fogta vissza tanítványát, hagyta, hogy a tehetsége szabadon fejlödjön. Így Munkácsy átugrotta a hosszadalmas és egy kiváló képességủ művésznek fölösleges közbenső akadémiai lépcsőket. Ezzel egyidőben gipsz- és élő modelleket rajzolt ceruzával és Szamossy képeit másolta színesben.“

${ }^{260}$ Ilges (1899), 27.0.: „[...] olyan gondtalansággal és önbizalommal kezdtem, amit soha többé nem éreztem. Szamossy módszere adta nekem a bátorságot, hogy saját magamra hagyatkozva kezdjek el festeni. A módszere azt volt, hogy a képet egy majdnem egyszínü háttérben fejezte be és a színeket később lazúrok segítségével vitte fel. Azt gondoltam, hogy a képet ugyanúgy kell megalkotni, moint egy ceruza- vagy szénrajzot. Nagy könnyebbség volt, hogy a színekkel nem csak később kellett foglalkoznom $[\ldots]^{\text {“ }}$
} 


\subsubsection{Rahl aláfestési technikája, a ,grau in grau“, és ennek hatása Munkácsy festészetére}

A velencei festőiskola által gyakorolt aláfestési móddal ("grau in grau”) Karl Rahl még Olaszországban töltött tartózkodási ideje alatt ismerkedett meg. Ezzel a módszerrel alapozta vásznait és ezt a technikai eljárást adta tovább tanítványainak. Az ún. „grau in grau“, avagy „szürke a szürkében“ elnevésű technikai eljárást francia szóval „grisaille“ néven is illeték. Szamossy Elek Rahl mütermében találkozott ezzel a technikai módszerrel, amit ő is továbbadott Munkácsynak. Mayer erről a technikai eljárásról kimerítően ír Rahlról szóló monográfiájában. ${ }^{261}$ Franz Hottner a Rahlról írt életrajzi művében szó szerint idézi a professzor szavait és gondolatait az aláfestési módszerről. ${ }^{262}$

\footnotetext{
${ }^{261}$ Mayer (1882), 7-18.o.: „A szürke aláfestés technikáját (grau in grau) Rahl fejlesztette ki. Noha már ő maga is rámutatott, hogy a velencei iskolában és Olaszországban másutt is időnként használták a szürke aláfestést, ő használta azt először szisztematikusan és arra épitette fel a festészetét. A korábbi festők esténként szürke alapra festettek aktmodelleket, azt csupán tanulmányként használták és nem szinezték ki később a képeiket. Ezért is nevezhetjük Rahl eljárását egyedüállónak! Annyira különbözött az addigi hagyományos festészettől, hogy soha nem volt erősebb kontraszt egy tantervben, mint amikor Rahl Dobiaschofskyval egy közös teremben oktatta a festészetet.“.

${ }^{262}$ Recensionen (1863), Franz Hottner: Carl Rahl. Biographische Skizze. 40.o.: „Ich habe gefunden“ sagte Rahl, „dass die Anwendung der Lasuren so alt ist, als die Oelmalerei selbst Ursprünglich wurde blos a tempera gemalt. Um sie zu erhalten, hat man die Gemälde sodann mit einem Oelfirnix überzogen. Um sie auszubessern und zu vervollkommen, hat man später Lasuren mittelst Oelfarben angewendet (Giovanni Bellini`s Methode), und so hat sich die Tempera - Malerei allmählich in eine Untermalung mit Deckfarben umgewandelt und das Fertigmachen mittelst Lasuren ist vorherrschend geworden. Später, beinahe in gleichem Verhältnis mit dem Verfalle der Kunst, wurde diese Richtung wieder verlassen. Der Gebrauch der Lasuren verminderte sich, und endlich wurden diese vor der Deckfarbe ganz verdrängt. Dadurch hat die akademische Malerei das Stumpfe und Schwerfällige bekommen, in welchem der Zauber und die Durchsichtigkeit der Oelfarbe nach und nach gänzlich erloschen sind. Daher rührt der erdige und kalte Ton und der vorherrschende Lichtmangel in den Gemälden aus jener Zeit. Ich suchte die Technik der Venezianer zuerst in einer Kopie nach Borghese in Anwendung zu bringen. - Uebrigens haben
} 


\subsubsection{A „Pesti Rahlianerek“6}

Munkácsy egész életében hálásan gondolt vissza a Szamossyval együtt töltött időkre, amelyröl 1882. február 21-én így nyilatkozott: "Szamossy, korán felismerte tehetségemet, korábban mint saját magam, így neki köszönhetem azt, akivé lettem.“،263 Szamossy, miután Munkácsy Mihály figyelmét arra irányította, hogy festészeti ismereteit más mesterek által is tovább kellene fejlesztenie, ajánlólevelet írt számára, ami a magyar mủvészvilág kapuinak a megnyitását is jelentette de ebben segítségére volt Harsányi Pál, a Képzőművészeti Társulat titkára is. ${ }^{264}$ Ennek köszönhetően került szoros kapcsolatba Munkácsy Szamossy barátaival, akik nagy része Rahl egykori tanítványai voltak. Munkácsy ezen időszakában ugyancsak fontos szerepet játszott Ligeti Antal, ${ }^{265}$ a tájképfestőként elhíresült magyar müvész, aki a későbbiekben Szamossy helyét vette át és atyai módon gondoskodott a fiatal tehetségről. Ligeti is Rahl nagy csodálója volt és neki is nagy szerep jutott Munkácsy azon elhatározásában,

auch die Venezianer verschiedeneVerfahrungsarten beobachtet. Bonifacio und Tizian haben mehr lasirt, Paul Veronese und Paris Bordone mehr mit Deckfarben gemalt. Die Art der Untermalung mit Grau in Grau lässt sich an mehreren, nicht ganz fertig gewordenen Bildern der großen Venezianerzeit erkennen. Ich selbst habe früher mit dunklem Grau untermalt, dann das Bild mit Deckfarbe, aber so leicht übergangen, daß das Grau durch die Deckfarbe durchschmierte, und ich die Modellirung der Untermalung benutzen konnte, erst zuletzt beim Fertigmachen habe ich bloß Lasuren gebraucht. Das eigene Porträt Tizians im Museum zu Berlin schien mir auf diese Art gemalt. Später habe ich es verzogen, die Untermalung beinahe weiß zu machen, und die Kraft und Rundung besonders in den Fleischtönen nur durch Lasuren erzeugen.“

${ }^{263}$ Ilges (1899), 27.o.: „Szamossy, der mein Talent früher erkannte, als ich selbst, ihm verdanke ich, was ich geworden bin!“

${ }^{264}$ Lyka (1942), 24.o.

${ }^{265}$ Ligeti Antalról Telepy Károly a következő információkat közli Jókai Mórral 1858-ban: Országos Széchényi Könyvtár, Kézirattár, Levelestár. Telepy Károly Jókai Mórnak. 1858. „Ligeti Antal. Tájfestész. Gróf Károlyi István pártfogoltja tegnapelöt e folyo ho 26 dikán indult el hazánkba vissza tévedö 4 évi távollét után ki is a nemes szivü grof költségen utazot Keleten Sziciliában és Olaszhonba.“ 
hogy Rahl közvetlen közelében sajátítsa el a festészet alapismereteit. Ligeti személyesen ismerte Karl Rahlt, akit itáliai, római tartózkodása alatt ismert meg. ${ }^{266}$ Malonyai Dezső Munkácsyról írt monográfiájában idézi Ligeti Antal, Munkácsy számára adott továbbtanulással kapcsolatos tanácsait. ${ }^{267}$

Than Mór, Lotz Károly és Ligeti Antal útmutatásával Munkácsy festészeti tudása egyre jobban kiszélesedett. Mesterei Munkácsy tehetségének megítélésében, illetve továbbtanulásának kérdésében is egységes állásponton voltak: A Bécsi Képzőmüvészeti Akadémiát mint földrajzilag könnyen megközelíthető, kevesebb anyagi terhet igénylő és politikailag kevésbé komplikált, nemzetözileg rangos intézményt ajánlották a fiatal tehetség figyelmébe, hiszen Karl Rahl bécsi magániskolájában is továbbbővíthette ismereteit. Ligeti Antal visszaemlékezései is ${ }^{268}$ alátámasszák Munkácsynak a fentiekben részletezett akadémiai választásának körülményeit. Rahl rehabilitációja 1863-ban történt, így Munkácsy 1864-es bécsi tanulmányainak a kezdetén, Karl Rahl magániskolája mellett már ismét az akadémia professzora is volt. Ebből fakadhatott az a téves elképzelés, hogy az akadémián Rahl tanítványa volt. ${ }^{269}$ Rahlhoz mindenesetre Than Mór ajánlólevelével érkezett, ami lehetővé tette, hogy Karl Rahlt személyesen megismerhesse. $^{270}$

Bécsi utazásának költségeit egyrészt festmények festéséből teremtette elő, másrészt alkalmi munkákból (címfestés). Ezen első festményei közé tartozik a "Felolvasás" címü képe is, amit egy Mitterdorfer nevü polgár vásárolt meg: “Amennyire vissza tudok emlékezni, Munkácsy a fent megnevezett paraszti életképét vászonra festette, amit én

\footnotetext{
${ }^{266}$ Malonyai (1898), 74.o.

${ }^{267}$ Malonyai (1898), 74.o. „Hogy Rahl tanárhoz csatlakozzék, - írja Ligeti-azt különösen azért javasoltam én is, mert nézetem szerint neki szükséges volt elöször is megismerni, hogy voltaképpen mi az a müvészet. Már pedig a müvészeti kérdéseknek ékesebben szóló tolmácsolóját ez idöben Rahlnál valóban nem ismertem, a miröl Rómában elég alkalmam volt meggyözödhetni, a midön emelkedett elöadásaival kortársai közül kimagaslott.“

${ }^{268}$ Ligeti (1891), Munkácsy Mihály ifjúsága, Budapesti Szemle, LXV. évf. 321-344.o.

${ }^{269}$ Bakó (2012), 10.o.

${ }^{270}$ Malonyai (1898), 74.o.
} 
tőle megvásároltam, és ebből a pénzből tudta a bécsi utazását finanszírozni. [...] Mennyi pénzt kaptam ezért a képért, arra már nem tudok viszaemlékezni, [...] Laccatarius volt a mentora, aki apailag gondoskodott róla. “271 A képei eladásában egy görög származású, képekkel házaló kereskedő,Laccataris ${ }^{272}$ segítette. Ezeket a munkákat görög barátjának köszönhette. ${ }^{273,274,275,276}$ A Pesti Mủgylet kiállításain Munkácsytól két ízben is állított ki festményt: Gyermek virágokkal, Családi kép. ${ }^{277}$

Bécs városából unokahúgaihoz címzett leveleiben 1865-ben szintén megemlíti "Paraszt felolvasás" címủ festményét, ami 80 forintért kelt el. "Felolvasás" 278 címmel pedig a Pesti Müegylet kiállításán is szerepelt. Pesti tartózkodása alatt Munkácsy több festményt festett, melyek még autodidakta időszakát tükrözik. ${ }^{279}$ Ennek az időszaknak lehet az alkotása a 2007-ben felbukkant "Naplemente" címủ festmény, hiszen még a

\footnotetext{
${ }^{271}$ Magyar Nemzeti Galéria. Kézirattár, Ilges (1901), 2.o.: „Soweit mir erinnerlich ist, malte Munkácsy sein oben genanntes Bauernbild auf Leinwand, die ich ihm gekauft hatte, und bestritt mit dem dafür von mir erhaltenen Geld seine Reise nach Wien. [...] Wie viel Geld ich dafür gegeben habe, dessen kann ich mich nicht mehr erinnern, [...]-das besorgte für ihn sein Mentor Laccatarius, der ihm väterlich zugethan war."

${ }^{272}$ Laccataris Demeter. In: Lyka (1942), 34.o.

${ }^{273}$ Magyar Nemzeti Galéria. Adattár, Ilges (1901), Munkacsy hagyaték. „Deutsche Revue“ júliusi különszáma. 2. o. „Ich kann Ihnen die Mittelung machen, dass ich im Besitze von Munkácsys allererster Bilde bin. Es ist von Ihm unterzeichnet und mit der Jahreszahl 1863 versehen. Ich besitze es seit jenem Jahre.“Tudatom önnel, hogy Munkácsy legelső képének birtokosa vagyok.A képet 1863-ban szignálta a festő.A kép ebben az évben került a birtokomba."

${ }^{274}$ Magyar Nemzeti Galéria. Adattár, Ilges (1901), 2.o.: ,[...] dagegen wurde er durch uns mit einem alten Maler, dem Griechen Laccatarius, bekannt, einem Manne von gleichem Schlage wie Szamossy. Bei dem durfte er mit Oelfarbe malen, das heißt solche Bilder, die Laccatarius zeichnete und unter seinem eigenen Namen verkaufte.“

${ }^{275}$ Lyka (1942), 34.o., 37.o.

${ }^{276}$ Ilges (1899), 30.o.

${ }^{277}$ Lyka (1942), 198.o.

${ }^{278}$ Lyka (1942), 70.o.

${ }^{279}$ Népszabadság (2007), Zavart okozott a „letartóztatott” Munkácsy mű. 2007. augustus 8.
} 
kiforrott festő megszokott ecsetvonásait, tulajdonságait nem viseli magán. Ilges közlése szerint ezen korai képek vásárlói között még Andrássy gróf nevével is találkozhatunk, aki a Pesti Műegylet által kiállított festmények közül választotta ki Munkácsy egy tájképét s 130 ezüstforitért vásárolta meg azt, valamint egy másik képet is vásárolt tőle. A gróf az 1880-as években nem kis büszkeséggel emlékezett vissza, hogy Munkácsy korai müvészéveiben őt már vásárlói között tudhatta. ${ }^{280}$ Pesti időszakára szívesen emlékezett vissza Munkácsy, amiröl Ilges is tett említést. Eszerint Munkácsy komoly társasági életet élt. ${ }^{281}$ Miután Munkácsy képei, munkái bevételéből fedezni tudta bécsi tanulmányainak a költségét, 1865-ben Bécsbe utazott.

\subsubsection{A Bécsi Képzőmúvészeti Akadémia 1864-1865 között.}

A Bécsi Képzőművészeti Akadémia beiratkozási papírjai alapján Munkácsy Mihály, akkoriban még anyakönyve szerint „Michael Lieb“282 iratkozott be annak előkészítő osztályába. A Munkácsy Mihályról szóló monográfiák nem rendelkeznek konkrét levéltári anyaggal ezzel az információval kapcsolatban. Maga a tény, hogy az akadémia diákja volt, minden róla szóló monográfiában szerepel. Az akadémiai tanárait is megnevezik, ami egy téves kompiláció eredménye. A beiratkozási papír segítségével a következő információkat tudhatjuk meg: Munkácsy az 1864-1865-ös tanévben látogatta a Bécsi Képzőművészeti Akadémia előkészítő évfolyamát, amit festők, szobrászok, építészek, plasztikai iskolások és rézmetszők számára indítottak. ${ }^{283}$

\footnotetext{
${ }^{280}$ Ilges (1899)

${ }^{281}$ Magyar Nemzeti Galéria, Adattár, Ilges (1901), 35.o.: "Was er malte, interessierte die Bekannten weniger als seine eigene Persönlichkeit, und was allen seinen Freunden aus jener Epoche fest in der Erinnerung geblieben ist, sind die lustigen Episoden, zu denen seine Originalität oder seine Zerstreutheit Anlaß gaben.“

${ }^{282}$ Universitätsarchiv der Akademie der bildenden Künste, Matrikel vom Jahr 1864-1865. I.Semester.
${ }^{283}$ Universitätsarchiv der Akademie der bildenden Künste, Matrikel vom Jahr 1864-1865. I. Semester.:
„[...] der Matrikel der im Studienjahr $1864 / 65$ in den Meister u. Vorbereitungsschulen für Maler,
} 
Munkácsy 1864 decemberében iratkozott be ebbe az osztályba, ${ }^{284}$ de az erről származó információ érdekessége, hogy az a 1865-1866-os beiratkozási papíron található. Munkácsy akkor még Michael Lieb név alatt a Bécsből íródott levelei alapján 1864 decemberétől élt a császárvárosban. ${ }^{285}$ Ennek ellenére az akadémiai papírok az 18641865-ös szemeszterben csak 1865 január 9-ét ${ }^{286}$ jelölik meg, majd az akadémiai tandíj befizetésének idejét, 1865. január 12-ét. ${ }^{287}$ Első bécsi lakhelye a Josefstadt-ban a Wickenburggasse 7 alatt volt. ${ }^{288}$ A beiratkozási papíron továbbá azzal a betoldással találkozunk, a Michael Lieb név mellett, hogy „Most Munkácsy Mihály“‘289

\subsection{Karl Rahl és Munkácsy Mihály kapcsolata}

Bécsi időszakát a Ligeti Antalhoz, unokahúgaihoz íródott levelei és Rahl egykori tanítványa, August George Mayer professzorról írt monográfiája teszi elemezhetővé. Karl Rahllal való kapcsolatáról maga Munkácsy nem sok információt hagyott ránk. Ligeti Antalhoz címzett leveleiből megtudhatjuk, hogy Than Mór ajánlólevele tette

Bildhauer in der Architektur, Landschafts, Schule für kleinere Plastik, und Kupferstecherschule aufgenommenen Zöglinge“

${ }^{284}$ Universitätsarchiv der Akademie der bildenden Künste, Martikel vom Jahr 1865-1866. II. Semester.

${ }^{285}$ Magyar Országos Levéltár-MOL. R227. Munkácsy Mihály levelei unokahúgaihoz, Reök Júlia, Sarolta, Ilka és Gabriella. 1864. december 27., Bécs.

${ }^{286}$ Universitätsarchiv der Akademie der bildenden Künste, Matrikel vom Jahr 1864-1865. I. Semester.

${ }^{287}$ Universitätsarchiv der Akademie der bildenden Künste, Matrikel vom Jahr 1864-1865. I. Semester.

${ }^{288}$ Universitätsarchiv der Akademie der bildenden Künste, Matrikel vom Jahr 1864-1865., Országos Széchényi Könyvtár-Kézirattár. Levelestár.Munkácsy Mihály levele Ligeti Antalnak, 1865. február 12., Országos Széchényi Könyvtár-Kézirattár. Levelestár. Munkácsy Mihály levele Ligeti Antalnak, Országos Széchényi Könyvtár-Levelestár. Munkácsy Mihály levelei Ligeti Antalnak, Levél Nr. 4, 1865. április 15.

${ }^{289}$ Universitätsarchiv der Akademie der bildenden Künste.Matrikel vom Jahr 1864-1865. I. Semester. Matrikel vom Jahr 1865-1866. : ,jetzt Michael Munkácsy“-,,Most Michael Munkácsy“ 
lehetővé, hogy Rahlt megismerje és magániskolájában tanulhasson. ${ }^{290}$ Munkácsy első bécsi lakhelye ugyancsak érdekes, hiszen ennek címe megegyezik Rahl egykori születési helyével: Josefstadt, Wickelburggasse 7. A cím az alábbi dokumentumon, leveleken szerepel. ${ }^{291}$ Rahl halála idején azonban nem ebben a házban lakott, amiről a Rahl gyászjelentése tanúskodik. ${ }^{292}$ Rahl és Munkácsy baráti, bensőséges kapcsolatáról Mayer könyvében találni bizonyítékot. Ebben Karl Rahl temetésével kapcsolatosan azt az információt találjuk, hogy Rahl koporsóját legkedvesebb tanítványai vihették a vállukon. Maga a temetés a korabeli Bécs egyik fontos eseményének számított, amelyen Bécs legfelsőbb köreihez tartozó előkelők is résztvettek. A temetésről a korabeli újságok is tudósíottak. ${ }^{293}$ Rahl temetése Bécsben és a korabeli fiatal művésznemzedék számára egy fontos eseményének bizonyult. Rahl koporsóját csak legkedvesebb tanítványai vihették a vállukon. Mayer monográfiájában pontosan név szerint megemlíti

${ }^{290}$ Országos Széchényi Könyvtár-Kézirattár. Levelestár. Munkácsy Mihály levelei Ligeti Antalnak. 28. sz. levél. 1869. Düsseldorf.

${ }^{291}$ Bécsi Képzőművészeti Akadémia Egyetemi Levéltára, Matrikel vom Jahr 1864-1865. Országos Széchényi Könyvtár-Kézirattár. Levelestár. Munkácsy Mihály levele unokahúgaihoz. 1864 december 27., Országos Széchényi Könyvtár -Kézirattár. Levelestár.Munkácsy Mihály levelei Ligeti Antalnak. 1. Levél., 1865 február 12., Országos Széchényi Könyvtár, Kézirattár, Levelestár. Munkácsy Mihály levelei Ligeti Antalnak, 2. sz. levél, 3. sz. levél., 1865.március 15., 4. sz. levél, 1865. április 15., Magyar Nemzeti Levéltár, MOL R227. Levelestár. Munkácsy Mihály levele unokahúgaihoz, 1865.március 10., (Az Országos Széchényi Könyvtár adatai között helytelen évszám szerepel! 1865 helyett 1866.)

${ }^{292}$ Mayer (1882), 178.o.: „Der Leichnam wird Mittwoch den 12. d. M., um 5 Uhr Nachmittags, vom Hause: Wieden, Theresianumgasse Nr. 31, in die Pfarrkirche [gebracht].“

${ }^{293}$ Ost-Deutsche Post (1865), Nr. 189, Carl Rahl, 1865.július 10., 3.o. : „[Es] versammelten sich die zahlreichen Verehrer und Freunde des dahingeschiedenen Künstlers, Mitglieder der „Concordia“ in besonders großer Anzahl, der Männesangverein, die Mitglieder der Akademie der bildenden Künste, die Wiener Künstlergenossenschaft vor der Paulanerkirche und begaben sich in dieselbe erst kurz vor Ankunft des Leichenwagens. [...] Um 5 Uhr langte der Leichenwagen, welchen die Schüler Rahl`s ( etwa 20 ) mit brennenden Windfackeln umgaben, beim Kirchentore an. [...] Acht Schüler des Verstorbenen hoben den Sarg, welcher von den Geistlichen am Kirchenthore empfangen wurde, ab und trugen ihn nach dem Presbyterium. [...] Die Schüler gingen, ihrem dahingeschiedenen Meister die letzte Ehre erweisend, mit den brennenden Windfackeln an der Seite des Leichenwagens nach dem Schmelzer Friedhof. Eine unabsehbare Wagenreihe folgte. [...] Eine zahlreiche Menge Theilnehmer hatten sich trotz des strömenden Regens eingefunden.“ 
kedvelt diákjai nevét, amelyek között Munkácsy Mihály neve is szerepel. Ez a dokumentáció eddig egyetlen Munkácsyról íródott monográfiában sem szerepel, pedig ez a Munkácsy és Rahl közti bensőséges kapcsolat egyik legnyílvánvalóbb bizonyítéka. ${ }^{294}$ Than Mór és Lotz Károly a megkésett értesítés miatt csak a temetés után tudta leróni a tiszteletét Rahl sirjánál. A temetést követő napon az egykori Rahlianerek egy közös megemlékezést tartottak, egy ún. „Gedächtnißfeiert“. ${ }^{295}$ A temetésen az udvar is képviseltette magát. Jelen volt az államminiszter, Ritter v Shnerling, az udvari kancellár Majlath, az osztályvezető Lewinsky, a Bécsi Képzőművészeti Akadémia professzorai illetve egyéb méltóságok. ${ }^{296}$

\subsection{Munkácsy Mihály Bécsben (1864-1865)}

Bécs képében Munkácsy első ízben találkozhatott egy európai szintü nagyvárossal. Ez a tapasztalat, a város sokszínűsége és az ebből fakadó élmények egész életére kiható élményekkel ajándékozták meg, amikre sok nosztalgiával emlékezett vissza a később világhírüvé váló festő. Bécs Munkácsy ott töltött ideje alatt fejlődött ténylegesen európai nagyvárossá. A várost körülölelö körgyürü, a Ring, ekkor épült ki. A Ring kiépítésének terve a forradalmi időszak után fogalmazódott meg, azt a célt szolgálva,

\footnotetext{
${ }^{294}$ Mayer (1882), 150.o.: „Rahls Leichenbegräbniß gestaltete sich großartig und eigenartig, da nicht geschätzmäßige Routine, sondern poesivolle Pietät die Anordnungen traf und selbst vollführte. Im rothsammtenen Sarg lag der Lorbeerbekränzte mir Blumen umrahmt, zu seinem Haupte die letzte Schlacht, in welcher er als ruhmreicher Held gefallen. Dem Trauerwagen, folgten zu Fuß seine Schüler und Akademiker mit Fackeln, hinter welchem erst die lange Wagenreihe im Schritt folgte. In der Kirche trugen ihn die Akademieschüler herum, vom Friedhofsthor an aber seine eigentlichen älteren Schüler und zwar: Hoffman, Eisenmenger, Bitterlich, Griepenkerl, Otto und Genelli, ich und Munkaczy.“

${ }^{295}$ Mayer (1882), 151.o.

${ }^{296}$ Ost-Deutsche Post (1865), Nr. 189, Carl Rahl, 1865. július 10., 3.o: Außer seinen Schülern war der Hof mit Personen wie „Herr Staatsminister. Ritter v Schnerling, , Herr Hofkanzler Majlath, Sektionschef Lewinsky und auch die Professoren der Akademie der bildenden Künste und andere Notabilitäten.
} 
hogy többek között a megingott uralkodó tekintélyét némileg helyreállítsa. Mindemellett a bécsi lakásszükség is szerepet játszott benne, valamint modernizációs törekvések.

A moderinzáció szellemében kultúrális intézmények sora épült fel és nyitotta meg kapuit a nagyközönség előtt, mint például az Állami Operaház, Várszínház, Archívum és a különböző múzeumok. Ezek a hatalmas építkezések a bécsi müvészvilágot is lázban tartották, hiszen megbizatások sorát jelentették. Karl Rahl például az Állami Operaház függönyét díszíthette festményével, illetve kisebb festmények megfestésére kapott megbízásokat az Arzenál pantheon lépcsőházában. Ennek a nagy volumenű építkezések és a kapcsolódó, hatalmas közintézmények kidíszítésék munkáiból a nyolcvanas években még Munkácsy is részesült, akit a Szépmüvészeti Múzeum kupolájába helyezendő festmény megfestésével bíztak meg. ${ }^{297}$ A Ringnek köszönhetően Bécs modern arculatot kapott. A város egykor még a középkorban épített városfala helyén épült ki a körgyürü. Többemeletes paloták és bérházak szegélyezték. Mindez nagy és hosszú ideig tartó építkezéseket jelentett, végleges állapotát csak 1875-ben érte el. ${ }^{298}$

Bécs elővárosaihoz tartozott többek között a Josefstadt - a Józsefváros. A belváros és a Józsefváros közötti részen terült el egy hatalmas beépítetlen rész, melyet „Glacis“- nak neveztek. A hadsereg gyakorlatozásainak egyik színtere volt. ${ }^{299}$ A modern várostervezés szellemében ezt a részt beépítették. A Munkácsy lakhelyéül szolgáló Józsefvárosnak is megvolt a maga sajátos arculata. Ezt az ún. polgári arculatát a mai napig megtartotta. (sajnálatos, hogy a Munkácsynak otthont adó Wickelburg utcácskai házra még nem

\footnotetext{
${ }^{297}$ A Bécsi udvar művészetének elismeréseként kérte fel erre a nagyszabású munkára 1886-ban.

${ }^{298}$ Jean Paul Bled (2002), Wien. Residenz, Metropole, Hauptstadt. Kapitel 5., Die Altstadt Und Die Vorstädte. 150.o.

${ }^{299}$ Bled (2002), 142.o.: „[...] geht das Glasic [gegenüber der Josefstadt] in ein Grünland über, das den Truppen der Garnison als Exerzierplatz dient.“
} 
került emléktábla). Bécs arculatváltozásáról Than Mór is megemlékezett 1865-ben keltezett, Hoffman barátjának írt levelében. ${ }^{300}$

Mikor 1864 decembere közepén Munkácsy Mihály Bécsbe érkezett, egy átalakulóban lévő városkép fogadta. F. Walter Ilges arról is megemlékezik, hogy Munkácsy egyik gazdag nagynénje Bécsben élt, akit a festő meglátogatott, de a család magyar érzelmeinek elfolytása és annak osztrák vendégei ellenérzéseket keltettek Munkácsyban. ${ }^{301}$

Erről a korai bécsi időszakról a Munkácsy monográfiák források hiányában nagyon visszafogottan nyilatkoznak. A Farkas Zoltán ${ }^{302}$ által összeállított Munkácsy leveleket közlő kötetböl a Bécsböl unokahugainak írt, alább idézett levelek hiányoznak. A legtekintélyesebb monográfiák szerzői, F. Walter Ilges, Rózsaffy és Végváry sem említik ezeket a forrásokat. A már említett Bécsi Képzőmüvészeti Akadémia beiratkozási papírjai jelentik ennek a periódusnak az egyik legfontosabb forrásanyagát, hiszen megtudható Munkácsy Mihály pontos tartókodásának címe és beiratkozásának ideje. Ez a bécsi időszak a fiatal festő szegénysége ellenére ${ }^{303}$ életének nagyon meghatározó élményévé vált, amiről az 1864-1865-ös keltezésű, unokahúgaihoz írt levelei is tanúskodnak. ${ }^{304} 1864$ karácsonyát még egyedül és magányosan töltötte, de az

\footnotetext{
${ }^{300}$ Mór Than an seinen Freund Hoffman. I. N. 75962. Wiener Stadt- und Landesbibliothek.Kézirattár:,,[...] Wien hat sich sehr verändert auf dem Glacis schön Gebeuden aber sind beinache kaum dort.“

${ }^{301}$ Ilges (1899), 32.o.

${ }^{302}$ Farkas Zoltán ed. (1952), Munkácsy Mihály válogatott levelei.

${ }^{303}$ Magyar Országos Levéltár-MOL. R227.Munkácsy Mihály levelei unokahúgaihoz, 1865.március 10,: „[...] Ne gondoljátok hogy tán befagyott a tintám (noha ez az én szobámban nem nagy csoda lett volna).“

${ }^{304}$ Országos Széchényi Könyvtár-Kézirattár, Levelestár. Munkácsy Mihály levelei unokahúgaihoz, Reök Júlia, Sarolta, Ilka és Gabriella, 1864. december 24.: „,...] Hogy töltöttétek a karácsonyt hiszem, hogy jobban, mint én, azonban a mi kristbaumunkat illeti nekünk is volt, még pedig oly nagy (?) hogy kiállítottuk a kleider stokhoz a szoba közepére, minden ágára kikötöztünk egy szál gyertyát, és ráakasztottuk valamennyi ócska ruháinkat egy szóval ily nemü kivilágítás volt nálunk, az elsö estet a második és a harmadikat egészen egyedül töltöttem. [...] Az én kedves mamucikám (?) hogy van, az új évi kivánatokból ö is épen olyan részt húzzon mint ti azon felül pedig ezerszer csókolom és kérem, hogy maradjon ö mindig az én Kedves mamuskám, mert én úgyis el vagyok már keseredve, nekem már nem
} 
ezt követő év februárját már társaságokban mulatta végig. Emellett nem feledkezett meg akadémiai tanulmányairó sem. A levelek egy szorgalmas és egyben jókedvű diák képét vetítik elénk. ${ }^{305}$ Levelein keresztül szobatársát is bemutatja unokahúgainak, akit Engel Gyulának $^{306,307}$ hívtak és a Bécsi Egyetem orvostanhallgatója volt. Munkácsy barátjával még pesti időszaka alatt ismerkedett meg és ez az ismerettség idővel barátsággá mélyült. ${ }^{308}$ Engel Gyula, Munkácsy egyik levelében sajátkezüleg ír barátja bécsi mindennapjairól, aki honvágya ellenére az idő múlásával egyre jobban érezte magát a Bécsben. $^{309}$

lehet élnitovább, én elmegyek meghalni. Isten véletek ti drága füszerei az én elkeseredett sótalan életemnek. Csokollak mindnyájatokat 777999 szer“

${ }^{305}$ MOL. R227. Munkácsy Mihály levelei unokahúgaihoz, 1865. március 10.

${ }^{306}$ Színyei József (1893) Magyar Irók Élete És Munkái, II.kötet, Engel Gyula, 1310-1311.o.

${ }^{307}$ MOL. R227. Munkácsy Mihály levelei unokahúgaihoz, 1865. március 10.

${ }^{308}$ MOL. R227. Munkácsy Mihály levelei unokahúgaihoz, 1865. március 10.

${ }^{309}$ MOL. R227. Munkácsy Mihály levelei unokahúgaihoz, 1865.március 10. „S ime egymást hatalmasan átkarolván folytatjuk kenyeres és szalonnás barátságunkat. Ö fest és sok egyebet csinál - én betegeket gyógyitok és szinte sok egyébb mast teszek. [...] Ha Miskát orvosi szempontból tekintem ugy mindig azt tapasztalom hogy valami ábrándos delliriumban van. Leggyakrabban hallom töle: " Hej Pécs, azáma Pécs! nem olyan mint a hideg Bécs!-azután meg “Ella! Ella!-(ez ám a dona (n felett kettözést jelölö vonal van!) bella!"-Gábris, Irén, és Sarolta és közöttük a jó Ilka!" - Hát még az a farsang! Azok a bálok! Ez a fiu olyan szerelmes -legyen elég mondván. hogy 20 éves. De én csak azt csudálom, hogy hideg februárban, hogy tud ily forró gondolatokat táplálni - mindent megpróbáltam már vele, de semi( kettözést jelölö vonal az m felett) sem tudja öt kiábrándítani, mint egy 5 krajszáros csikó, azután bele buvik az ö lyukakban gazdag szürébe és naphosszat ott ül és másol s ha meg másol akkor plane még az éijel is nappallá tenné. S fütyül oly keserves notákat, hogy a szoba falairól is csurognak a könyek." 


\subsection{Az 1865-ös bécsi farsang}

Munkácsy Mihály, 1865-ös bécsi farsangi időszaka családtagjainak írt levelei mellett ${ }^{310}$ a kortárs napilapok cikkeinek segítségével jól rekonstruálható. Fontos forrásként szerepel a Wiener Zeitung, "Zur Tagesgeschichte" vagyis napi hírek, valamint a „Sehenswürdigkeiten“, látnivalók címü rovata, amik a februári bálok pontos ideje, helye, majd ezek történései elevenenítik meg cikkeikben.

Ezek tükrében látható, hogy a legnagyobb bálokat a Bécs folyónál található császári és királyi magánszínházban („,k. u. k. priv. Theater an der Wien“), józsefvárosi császári és királyi magánszínházban (,k. u. k. priv. Theater in der Josephstadt“) és a Szófia Teremben (Sophien-Saal) tartották, ahol Joseph és Eduard Strauß vezényelt. Jelentősek voltak a Diana teremben (Diana-Saal) és a császári és királyi Redoute-ban megtartott bálok: mint a Polgári Szövetség, egyetemi, álarcos és Hesperus, vagy müvészbálok, amelyeken Johann Strauß zenekara játszott. Ezeken kívül a hietzing-i Dommayer Casinójában, a leopoldvárosi Sperlben és az Odeonban, valamint Schwender Colosseumában, illetve a császári és királyi kerti épületben megrendezett táncvígalmak is nagy érdeklődésnek örvendtek a bécsiek körében. ${ }^{311}$ Munkácsy tehetős magyar barátainak köszönhetően a várost és lakóit a vidámabb, gondtalanabb oldalukról is megismerhette. Az 1864-ben keltezett leveleihez képest gyökeres fordulatot vett Munkácsy élete, aki maga is meglepve állt a fordulatos bécsi farsang elött. ${ }^{312}$ Bécsből

\footnotetext{
${ }^{310}$ MOL. R227. Munkácsy Mihály levelei unokahúgaihoz, 1865.március 10., Ezeket a leveleket nem használta fel egyetlen Munkácsyról szóló monográfia írója sem. Jelen dolgozat szerzője az első, aki ezeket a leveleket feldolgozta.

${ }^{311}$ Wiener Zeitung 1865.februári repertoárja.

${ }^{312}$ MOL. R227. Munkácsy Mihály levelei unokahúgaihoz. 1865. március 10.: „Elöször is azt mondom, hogy én valóban nem voltam el elkészülve arra, hogy Bécsben sokkal jobb farsangot töltsek, mint még eddig mindenütt ahol csak léteztem. Mert azt hittem, hogy nekem ebben a német faluban el kell keserednem és olyan jámbor szolid és magányos életet élnem, mint noénak a bárkában. [...] ez azonban
} 
küldött leveleiben a szegedi Vasvári Ernő nevét említi, aki vagyona révén lehetővé tette számára a farsangi bálokban való részvételt. ${ }^{313,314}$ Szegedi barátjának köszönhetően végetért melankólikus hangulata és márciusban keltezett leveléből megtudhatjuk, hogy a báli szezonban, azaz 1865 februárjában, nem kevesebb, mint tizenkilenc táncmulatságban vett részt. ${ }^{315}$

A bálok közül megemlít egyet, amelyen a császár és a császárné is jelen voltak. A Wiener Zeitung is megemlékezett napi hírek rovatában (1865. február 11.) arról a polgári bálról, amelyen a császári pár is jelen volt. A bálra a Józsefvárosban került sor Vinzenz Auersperg herceg palotájában. ${ }^{316}$ Nemcsak Munkácsy, a cikk is nagy

nem igy volt, s az istenek könyvének 999 dik lapjának s annak 999sorában ugy volt fel jegyezve, hogy én mulatva Töltsem életem 20 évének farsangját , és ez igy is lett.“

${ }^{313}$ MOL. R227. Munkácsy Mihály levelei unokahúgaihoz. 1865. március 10.

${ }^{314}$ MOL. R227. Munkácsy Mihály levelei unokahúgaihoz. 1865. március 10.: ,[...] küldötte az Isten az én farsangi vigasztalómul, de meg is vigasztalt mert nem hagyott két napig egymásután az én csendes magányomban pihenni hanem ha egy estve el telt csendesen, a másik esten semi esetre sem maradt el, de jött és addig hitt vonszolt még el kelletett vele mennem valamely bálba“.

${ }^{315}$ MOL. R227. Munkácsy Mihály levelei unokahúgaihoz. 1865. március 10.

„19 bálban voltam, és azon kivül sok más mulatsagokban. [...] Elösször is voltam egy Polgár bálban a hol a csázsár es csázsárné is jelen voltak egy kevés ideig. - Ez nagy szerü volt. [...] Képzeljétek azt kedveseim egy királyilag díszített terembe, mely egy pár ezer gáz lángtól van világítva, s gondoljátok hozá fogalmaitok szerint a legjobb zenét, s látni fogjátok a Becsi ugy nevezett Polgári bált a császárés felesége mint egy óra hosszát voltak jelen.“

${ }^{316}$ Wiener Zeitung (1865), Zur Tagesgeschichte, 1865. február 11. : „, ,..] in dem seenhaft decorierten Palais, wo gediegener anererbter Luxus mit dem feinsten Geschmacke Hand in Hand geht, die glanzvollste Gesellschaft von Wien und genoß die hohe Auszeichnung, Ihre Majestäten den Kaiser und die Kaiserin zu den Gästen zählen zu dürfen. [...] Ihre Majestäten erschienen um 10 1⁄2 Uhr .Se. Majestät trugen die Uniform eines Kürassierobersten, Ihre Majestät die Kaiserin im Haare frische Blüthen von weißen Jyacinthen, mit Amethysten kunstvoll zu Blumenbüscheln geordnet, um den Hals ein Collier ebenfalls von Amethysten. [...] Im Ganzen dürften an $\mathbf{4 0 0}$ Personen versammelt gewesen sein.“ 
méltatással ír a díszes termekről és az ezeket látogató nagyúri közösségről. ${ }^{317}$ Munkácsy levelének további érdekessége, hogy egy magyar Kendefi névre hallgató úrhölggyel való megismerkedéséről mesél. ${ }^{318}$ Majd egy későbbi Engel Gyulához íródott leveléből kiderül, hogy a hölgy egy magyar grófnő volt, aki a festőre nagy hatással volt, hiszen a levél egyik sarkallatos pontja a grófnőről való információ. ${ }^{319}$ A Kendeffy név a legmagasabb körökhöz tartozott. Munkácsy levelében a közölt személynév írásakor nem törekedett annak helyességére, ahogy ez leveleiben más nevek esetében is számtalanszor előfordul. A Wiener Zeitung báli cikke pedig megemlíti azon főnemesi családokat, akik ezen a bálon jelen voltak. ${ }^{320}$

\footnotetext{
${ }^{317}$ MOL. R227. Munkácsy Mihály levelei unokahúgaihoz. 1865. március $10 .:,[\ldots]$ a deli hölgyek hatyu nyakain igazi gyöngyök, gyémántok folytak le, [...] Ismét egy másnak furfangosan bodrozott gazdag hajzatából mint egy gúnyolólag tekéntett a sok gyémánt hajtü szembe a rá tekintövel“

${ }^{318}$ MOL. R227. Munkácsy Mihály levelei unokahúgaihoz. 1865. március 10.

„Mint egy 2 óra tájon azonban meg ösmerkedtem egy bizonyos Kendefi nevï Magyar úrhölgyel és ez véget szakította az unalomnak $[\ldots]^{\text {“ }}$

${ }^{319}$ MOL. R227. Munkácsy Mihály levele [Angyal Gyulához] 1871. (A címzett neve saját kutatási eredmény): „No hanem már mostan egy pár szot, a Becsi multbol. Hogy vagytok? Mit csinál a Magyar korona? Mit csináltok ti? [...] A Grófnét láttad e azóta? - Mind erre minél elöbb felelj. - Ha a magammal hozott, és most is elöttem hervadó babérkoszorú nem tenne bizonyságot. Csak ugyan azt hinném ,hogy az a néhány nap csak egy muló álom vala. - - a melyböl fel kellett ebrednunk , nem ugyan, mint a szerelmesek mindjak egy " borzaszto" valora, hanem egy tevékeny napra, melyen az embernek, a hervadó baberok helyett frisseket kell szerezni. [...] (Túl igyekeznem én magam is, s azért erösen munka után láttam).”
}

${ }^{320}$ Wiener Zeitung (1865), Zur Tagesgeschichte. 1865. február 11., 465.o.: „,[..] unter den Gästen befanden sich die Herzoge Philipp und Alexander von Württenberg, die fürstlichen Familien Lichtenstein, Schwarzenberg, Esterházy, Kinsky, überhaupt die Blüthe des hohen Adels.“ 
Munkácsy és barátai a leggyakrabban az ún. Semper-ben megrendezett bálokat látogatták, ott is a magyar zenét szolgáltató termet. ${ }^{321}$ Ez a leopoldvárosi szórakozóhely az 1860-as években nyitotta meg kapuit a nagyközönség előtt. Többemeletes épületről lévén szó, annak különböző termeiben más és más zenével lepték meg az ide látogatókat. Bécs lakói körében a legnépszerübbek az álarcos bálok voltak. Az ilyen típusú bálok popularitása azok magas számában mutatkozott meg. Ezt a Wiener Zeitung bálokról szóló hírdetéseiben szereplő számarányuk is alátámasztja. ${ }^{322}$ Munkácsy és baráti köre is szívesen látogatta az ilyen típusú rendezvényeket. ${ }^{323}$ A bécsi farsangi hangulat és Johann Strauß melódiáinak szeretete hátralevő életében végig kísérték Munkácsyt. Strauß zenemüveinek szeretetéről egy feljegyzése is fennmaradt. ${ }^{324}$

\subsection{A Bécsi Képzőmúvészeti Akadémia 1865-ben}

\subsubsection{A Bécsi Képzőmúvészeti Akadémia előkészítő osztálya}

1865-ben Munkácsy Professzor Wurzinger ${ }^{325}$ és nem Karl Rahl tanítványa ${ }^{326}$ volt a Bécsi Képzőművészeti Akadémia előkészítő osztályában. Ennek teljesítése, előfeltétele

\footnotetext{
${ }^{321}$ MOL. R227. Munkácsy Mihály levelei unokahúgaihoz. 1865. március 10..: „[...] Kerestük pedig leggyakrabban, az úgy nevezett Semperben, a hol a belépö mintegy örvendö nagy világban képzeli magát lenni az egy másba fojó számtalan termeknek mindegyikéban külön zene, tánc, folksinger szini elöadás mulattatják a közönséget, és ez mind egy házban. Mi azonban legjobban kerestük a Magyar zenét (mert az is volt bezony) és annál mulattunk egy pár össze verbuválólt Magyar másokkal.”

${ }^{322}$ Wiener Zeitung (1865), januári és februári repertoárjai.

${ }^{323}$ MOL.R227. Munkácsy Mihály levelei unokahúgaihoz. 1865. március 10.:,,[...] A maszk bálokban nagyon könnyü volt kellemes ösmeretségeket csinálni [...] ezektöl egy párat fel tartottam magamnak.“

${ }^{324}$ Magyar Nemzeti Galéria. Adattár.

${ }^{325}$ Polenyák Ivett (2012), Munkácsy Mihály és Carl Rahl kapcsolata (1865), In: Strausz Péter-Zachar Péter Krisztián ed. (2012), Történelmi emlékezet és Identitás. 128-144.o.
} 
volt további akadémiai tanulmányainak. Európa nagy müvészeti akadémiái ezzel a bizonyítvánnyal nyílhattak meg a fiatal festő előtt. A Bécsi Képzőmüvészeti Akadémia előkészítő osztályának szabályzata Gróf Leo Thun minisztersége alatt készült el 1851. január 11-én. ${ }^{327}$ Ebben benne foglaltatik, hogy az osztály tanulóinak sikerességét, művészi individualitását leginkább az szolgálja, ha egyetlen egy nevelő segíti az osztályt, hiszen a tanárok közötti teljes összhang nem volt garantálható, egy közös irányítás pedig nehezen volt megvalósítható. A tanulók művészeti fejlődését leginkább az szolgálta, ha egyetlen egy tanárra hagyatkozhattak, akinek az volt a feladata, hogy tantárgyaikat összehangolja és ezekből az anyagokból a tudását átadja. ${ }^{328}$ 1865-ben a Bécsi Képzőművészeti Akadémia megváltoztatta tanügyi szabályzatát, ami pontosan Munkácsy tanulmányainak idejére esik. Ennek a modernizálásnak volt köszönhető, hogy a Bécsi Képzőművészeti Akadémia három újonnan kinevezett professzort fogadhatott: Franz Dobyaschofskyt, Karl Rahlt és Hans Gassert. ${ }^{329}$

Az előkészítő osztállyal szemben az ezt követő akadémiai osztályokban a tantárgyakat már különböző professzorok oktatták. Franz Dobyaschofsky, Karl Rahl és Kupelwieser ${ }^{330}$ professzorok tanították a természet utáni festést és rajzolást, az antik tanulmányokat valamint az akt ábrázolást. ${ }^{331} \mathrm{Az}$ akadémia modernizálása akkor a legszembetűnőbb, ha egybevetjük annak korábbi tanítási metódusával. Ez a vallásos müvészetet tekintette egyedüli művészi értéknek, az akadémia professzorai ezt ismerték

${ }^{326}$ A legújabb Munkácsy monográfiák még mindig Karl Rahl nevéhez kötik bécsi akadémiai tanulmányait! In: Bakó Zsuzsanna (2012), 10.o., Bakó (2008), 10. o.

${ }^{327}$ Gróf Leo Thun: Kultúrális és Oktatási miniszter volt 1849-1860 ig. Megreformáltatta az osztrák oktatás képzési rendszerét.

${ }^{328}$ Wagner (1967), 153-154.o.: „Der Erfolg hängte in ihr vom persönlichen Einfluss und den Grundsätzen der Lehrer ab. Da deren vollständige Übereinstimmung nicht vorausgesetzt werden könne, sei eine über Handhabung der äußeren Ordnung hinausgehende gemeinsame Leitung schwer durchführbar und vielfach gefährlich für die Entwicklung der künstlerischen Individualität. Die Schüler sollten sich daher der ausschließlichen Leitung eines Meisters an allen Fächern anvertrauen.“

\footnotetext{
${ }^{329}$ Hans Gasser (1817-1868), osztrák festő és szobrász.

${ }^{330}$ Leopold Kupelwieser (1796-1862), osztrák festő.

${ }^{331}$ Wagner (1967), 153.o.
} 
el. Az ábrázolni kívánt téma gyakorlatilag három fogalom: isten, ember és a természet körül mozgott. ${ }^{332}$ Az akkori akadémiai professzorok, Führich és Kupelwieser munkái ennek legékesebb bizonyítékai. ${ }^{333}$ Nézeteik szerint a mindennapi életképeket ábrázoló ún. Genremalerei- életképfestészet, vagy az antik témákat is feldolgozó klasszikus festmények nem a művészetet, hanem a luxust és a divatot szolgálták. ${ }^{334}$ Azért kerülhetett sor arra, hogy Karl Rahl és Franz Dobyaschofskyt müveik és a reneszánsz korokra visszanyúló tanítási metódusuk miatt ekkor az akadémiáról száműzték. Rahl professzor ezek után nyitotta meg tizenöt tanítványa ${ }^{335}$ segítségével magániskoláját. Ennek alapító tagjairól Mayer részletes listát közöl: "Eichholzer, Euler, Gaul, Gerhardt, Krauthauf, Latoczi, Mayer, Mantler, Pauly, Pieringer, Romako, Thann, Uetz, Walch und Weißman. ${ }^{\text {‘33 }}$ Hottner ezzel szemben huszonöt tanítványról tesz említést, de nevek közlése nélkül. ${ }^{337}$

Az 1864-65-ös akadémiai évben az előkészítő osztály órarandje a következő tárgyakon alapult, amit Munkácsy Mihálynak is teljesíteni kellett: antik minták utáni rajzolás és modellezés, természet utáni rajzolás, modellezés és festés (akt, modell és drapéria), kompozíció oktatása, ennek megbeszélése az erre jelentkezett tanulókkal, valamint a régi idők mestereinek komponálási technikájának magyarázata, teoretikus előadások általános és osztrák történelemböl, mitológiából és művészettörténetböl. Perspektíva festőknek, ugyanígy anatómia. Rézmetszők technikájának oktatása. ${ }^{338}$ Az 1863-as

\footnotetext{
${ }^{332}$ Wagner (1967), 55.o.

${ }^{333}$ Wagner (1967), 155.o.

${ }^{334}$ Wagner (1967), 155.o.

${ }^{335}$ Mayer (1882), 70.o.

${ }^{336}$ Mayer (1882), 70.o.

${ }^{337}$ Recensionen (1863), Fr. Hottner: Carl Rahl, 59.o.

${ }^{338}$ Wagner (1967), 150.o.: „Zeichnen und Modellieren nach der Antike, Zeichnen, Malen und Modellierennach der Natur (Akt, Modell, Gewänder),Kompositionsunterricht mit Durchsicht und Besprechung von Kompositionen der sich zu diesem Unterricht meldenden Schüler und Erklärung der Kompositionen alter Meister - also eine Abweichung von dem Plan Franz Thuns und den seinerzeitigen Komissionbeschlüssen. [...] Theoretische Vorträge über allgemeine und österreichische Geschichte, Mytologie, über Kunstgeschichte, Perspektive für Maler sowie Anatomie für Künstler. Unterricht in der
} 
évben az oktatási minisztérium a perspektíva és az anatómiai előadások látogatását a festő és a szobrász hallgatók számára kötelezővé tette, e tantárgyakból vizsgázniuk is kellett. $^{339}$ A tandíj befizetése minden hallgatónak kötelező volt. Munkácsy Mihály, akkor még Michael Lieb, is eleget tett ennek a követelménynek akadémiai beiratkozási papírjai alapján, 1864. január 12-én, 400 gulden (forint) összegben. ${ }^{340}$

Munkácsy Bécsben töltött akadémiai ideje és Karl Rahl rehabilitációja egy időre esett. Rahlnak harminc évet kellett arra várnia, hogy az akadémia elismerje. A rahli modern művészeti gondolatok azonban ebben az időszakban már idejemúltnak tünhettek. Az akadémia igazgatójának, Kupelwiesernek ${ }^{341}$ 1862-ben bekövetkezett halála után Christian Ruben ${ }^{342}$ lépett a helyébe. Egy 1863-ban tartott akadémiai ülésen megfogalmazódott, hogy olyan professzorokra lenne szükség, akik a kor élvonalbeli művészei közé tartoznak. Elsősorban német művészeket szerettek volna az akadémiai oktatásra felkérni. Ennek megvalósítása azonban sok nehézségbe ütközött, de a császári elhatározás már ennek a javaslatnak a szellemében született meg. Karl Rahl elfoglalhatta katedráját. Sajnálatos, hogy Rahl 1865 júliusában bekövetkezett hirtelen halála vetett véget akadémiai munkájának. ${ }^{343}$

Rahl privat művészeti iskolájában végzett munkája azonban nem volt hiábavaló. Tanítványai közül pl. Christian Griepenkerl később az akadémia professzora lett. ${ }^{344}$ Magyar tanítványai közül Than Mór és Lotz Károly személyében a monumentális falképfestészet magyarországi úttörőiröl beszélhetünk. Munkácsy Mihály pedig

Technik der Kupfelstecherei. „Ausnahmsweise für jetzt noch“ wurde dieser Zweig bis nach der Jahrhundertwende unterrichtet.“

${ }^{339}$ Wagner (1967), 174.o.

${ }^{340}$ Universitätsarchiv der Akademie der bildenden Künste Wien.Matrikel vom Jahr 1864/865.

${ }^{341}$ Kupelwieser, Leopold (1796-1862), osztrák festő. In: Zádor (1962), 111, 491.o.

${ }^{342}$ Christian Ruben (1805-1875), német festő. 1852-1872 között a Bécsi Képzőmüvészeti Akadémia igazgatója.

${ }^{343}$ Wagner (1967), 177-178.o.

${ }^{344}$ Christian Griepenkerl (1839-1912), A Bécsi Képzőmüvészeti Akadémia professzora 1875 és 1910 között. 
világhírnévre tett szert. Sajnálatos, hogy az 1852 és 1865 között akadémiai tanulókról vezetett naplók megsemmisültek, amelyekben a tanulók müvészeti fejlődésmenetét jegyezték fel tanáraik. ${ }^{345,346}$

\subsubsection{Bécsi múvészélet 1865-ben}

Munkácsy müvészetére nagy hatással volt a bécsi akadémiai időszak. Ez a befolyás elsősorban Karl Rahl útmutatása, valamint a Bécsben látott kiállításokon keresztül érvényesült. August George Mayer visszaemlékezései alapján rekonstruálható, hogy Rahl mủvészeti és tanítási metódusa hogyan éreztette hatását növendékei körében. Ennek sarkallatos pontját alkotta a reneszánsz kori mesterek müveinek másolása is. Ezt a gyakorlati módszert saját ifjúkori tapasztalatai alapján ajánlotta tanítványainak. Annak ellenére szorgalmazta ezt, hogy e miatt nagyon sok támadás érte. Ezeknek a negatív kritikáknak volt köszönhető, hogy a bécsiek csak egy utánzónak, a régiek imitátorának (,ein Nachahmer, ein Imitator der Alten“3347) tartották. ${ }^{348,349}$

\footnotetext{
${ }^{345}$ Wagner (1967), 163.o.

${ }^{346}$ A Wiener Stadt- und Landesarchiv -ban végzett kutatómunka eredményeképpen az is kiderült, hogy ezeket az aktákat kiszoltírozták és megsemmísítették. Forrás: Pia Mörtinger Gromann, levéltáros. Wiener Stadt- und Landesarchiv.

${ }^{347}$ Mayer (1882), 3-4.o.

${ }^{348}$ Mayer (1882), 3-4.o.: „Die berühmten Werke verschiedener Meister copierte er geistvoll in Farbenskizzen, und diese Sammlung auserlesener Conceptionen wurde Ausgangs- und Anhaltspunkt für seine eigenen Darstellungen.“

${ }^{349}$ Mayer (1882), 5.o.: ,[...] Sein eigener Entwicklungsgang wurde wiederum die Basis seiner Lehre. Seinen Schülern empfahl er das Studium der Alten, nicht deren äußerliche Nachahmung, und so wurde in seiner Schule die Individualität mehr berücksichtigt, als irgendwo, da zu deren obersten Grundsätzen Wahrheit, d. h. Uebereinstimmung mit sich selbst zählte.“
} 
A Rahl tanítványok ugyanakkor követték Rahl tanácsait, de mindemellett a saját útjukat járták. Professzoruk pontosan tisztában volt tanítványai adottságaival, erősségével, illetve gyenge pontjaival. Ezeket figyelembevéve nem törte meg müvészi individuumukat. Munkácsy bécsi tanulmányai elkezdéséig intézményes keretek között nem tanult. A Rahlianerek ugyanakkor egykori professzoruk szellemében tanították. Bécsben Rahl magániskolája így közelebb állhatott hozzá egy atyai tanácsadóval, mint az akadémia a maga szabályaival. Ugyanakkor Munkácsy akadémiai professzorának, Karl Wurzinger festményeinek címe elárulják, hogy a mester, akárcsak Rahl, az ókori mitológiai témákhoz is vonzódott. ${ }^{350}$ Klasszicista stílusban is alkotott.

Munkácsy bécsi oktatóival kapcsolatos érdekesség, hogy a korábbi Munkácsy monográfiákban Rahl és Wurzinger tanításainak háttérdokumentációja egyáltalán nem, vagy tévesen szerepelt. Malonyai anekdótákra is épített monográfiája alapján téves információkat is tartalmaznak. Munkácsy azon kijelentése, hogy unta az akadémiai órákat, további feltételezésekhez vezetett, melyek szerint akadémiai professzora nem kedvelte a festőt. A tények ennek ellentmondanak, hiszen a kedvelt rahli metódus nem volt idegen Karl Wurzinger számára sem.

1864-ben Rahl professzor az akadémia ülésén a monumentális müvészet fontosságára hívta fel a figyelmet és annak az akadémia által iránymutatásra alkalmas voltát emelte ki. ${ }^{351}$ Az akadémia igazgatója, Christian Ruben azonban elutasította kérését. Ebben fontos szerepet játszott az, hogy az akadémiának reális nézeteket kell vallania az oktatás terén. Figyelembe kelett vennie a közönség igényeit. Ez pedig nem a monumentális művészet irányába mutatott. Nem biztosított volna az akadémiáról kikerülő növendékeknek munkalehetőségeket. ${ }^{352} \mathrm{Az}$ 1860-as években a művészeti irányzatok közül a realizmus egyre nagyobb teret hódított a müvészeti életben. A monumentális

\footnotetext{
${ }^{350}$ D. von Vincenti (1876), 262-263.o.: „Apokaliptische Reiter“, „Hectors Abschied“, „Saul und David“, Felesége portréja.

${ }^{351}$ Mayer (1882), 172-173.o.: „Dezember 1864 [...] Rahl trat dafür ein, Historienmaler zu bevorzugen, da der Staat einen monumentalen Stil brauche und die Akademie schließlich eine Staatsanstalt sei. Die ideale, nicht die reale Kunstrichtung solle an der Akademie maßgebend sein.“

${ }^{352}$ Wagner (1967), 172-173.o.
} 
müvészet ideje lejárt és a müvészetekért lelkesedő publikum figyelme a realizmus irányába fordult.

\subsubsection{Az 1865-ös bécsi müvészeti kiállítások}

Az 1857. augusztus 23-án császári jóváhagyással ismételten engedélyezték az akadémiának a mükiállítások megnyitását, amelyre 10. 000 florentinert utaltak ki az államkincstárból. Ezt az összeget három éven belül lehetett belföldi és külföldi képzőművészeti művek vásárlására fordítani. ${ }^{353}$ A művészeti kiállítások zöme az 1860as évben a Császári és Királyi Iparművészeti Múzeumon kívül a privát galériákban volt látható. Rahl tanítványai ezekben másolták Munkácsyval együtt a régi mesterek festményeit. Munkácsy Mihály akadémiai kiállításokat is látogathatott. A napilapok is tudósítottak az aktuális kiállításokról. A Wiener Zeitung (Bécsi Ùjság) napi hírek („Tagsgeschichte”) $)^{354}$ rovatában ismertette ezeket a kiállításokat. A Wiener Zeitung 1865-ös 149-es számából azt is megtudhatjuk, hogy az Iparmüvészeti Múzeumot délelőttönként a művészek reggel hét órától tizenegy óráig ingyenesen látogathatták. ${ }^{355}$ A múzeumban feljegyezték az itt dolgozó és másoló festők nevét, de ezek a listák az idők folyamán megsemmisültek. ${ }^{356}$

Munkácsy lakótársa, Angyal Gyula is említést tett a festő unokahúgaihoz íródott

\footnotetext{
${ }^{353}$ Wagner (1967), 171-172.o. : „Überdies bewilligte Franz Joseph 10. 000 fl. aus dem Staatsschatz für drei Jahre zum Ankauf in- und ausländischer Werke auf den Ausstellungen für die Galerie im Belvedere.” ${ }^{354} \mathrm{~A}$ Wiener Zeitung 1865 . évi februári repertoárja.

${ }^{355}$ Wiener Zeitung, (1864), Nr.149. Donnerstag, 16 Juni. 1864. 878.o.: „K. K. Museum für Kunst und Industrie. Von 7-11 Uhr Freier Eintritt für Künstler, Industrielle, gewerbliche Hilfsarbeiter und andere Personen, welche im Museum zeichnen, modellieren, oder in anderer Art arbeiten wollen. Von 11-2 Uhr. Freier Eintritt für das Publikum.“

${ }^{356}$ Wiener Stadt- und Landesarchiv-ban, Vlagyimir Aichelburg levéltáros szíves közlése alapján.
} 
levelében arról, hogy barátja szorgalmasan másol. ${ }^{357}$ Mindezt már pesti időszaka alatt is gyakorolta a Nemzeti Képtárban Ligeti Antal felügyeletével. A Wiener Zeitung 1865-ös repertoárja alapján a közzétett kiállításokról a következő konklúzió vonható le:

A legtöbb kiállított képzőmüvészeti munkát az Osztrák Művészeti Egyesület kiállításainak a keretében osztrák művészektől állították ki. A külföldi kiállítók közül legnagyobb számban német festők képviseltették magukat. 1865 januárjában az Osztrák Mủvészeti Egylet 63 olajképet, 440 aquarellt és rajzot, és néhány kis plasztikai müvet állíttatott ki. A kiállító müvészek közül kiemelkedik Karl Rahl és Angeli neve is.

Munkácsy Bécsben keltezett leveleiben a kiállított képekkel kapcsolatosan egyetlen egy esetben fejti ki véleményét. Amikor Ludwig Knaustól került kiállításra a „der Gaukler”, vagyis a „Szemfényvesztő” címü festmény, ami meghatározta a festő művészeti pályájának további alakulását. Munkácsy Bécsben festett képeit témájuk alapján két nagy csoportba sorolhatjuk. Az első csoportba azok a képek tartoznak, amik nagy valószínűséggel a festő megélhetését fedezték. A másodikba pedig azok, amiket akadémiai tanulmányai alkalmából festett. A megélhetését szolgáló képek témáit tekintve portrék, amelyek egy része ismerőseit, rokonait ábrázolja. ${ }^{358}$

Akadémiai tanulmányai alkalmából készült festményeiről kevés háttérinformációt találunk. A „Paraszt felolvasás” címü képét Pestre küldte, hogy ott az általa ,általános kiállításnak” nevezett Müegyleti tárlaton állíttassa ki, bár a festmény eladását tekintve illetőleg bizonytalan volt. A „Húsvét” című festményéről azonban egy fotográfiát is szeretett volna mellékelni a leveléhez. ${ }^{359}$ Munkácsy akadémiai óráival kapcsolatosan is

\footnotetext{
${ }^{357}$ MOL. R 227. Munkácsy Mihály levele unokahúgaihoz. 1865. március 10.

${ }^{358}$ Ilges (1899), 32.o.: „[...]A későbbiekben gyakran arról is mesélt, hogy bécsi tartózkodása kezdetén meglehetősen sokszor kapott meghívást egy gazdag nagynénjéhez, de ezek rövid idő elteltével megszakadtak.“

${ }^{359}$ MOL. R227. Mihály Munkácsyslevelei unokahúgaihoz. 1865. március 10.: „Ami el foglaltatásom illeti, most már szorgalmas vagyok ha nem a farsang alatt, nem dicsekedhettem volna vele, noha az akadémiai órákból csak 4et mulasztottam. A kis paraszt felólvasásomat le küldtem Pestre, az általános kiállításba, itt csak nagyon bizonytalan hogy megveszik e. A húsvétot ábrázoló képemen dolgozom egyre másra.Ha kész lesz, küldök belöle egy photográfiát."
} 
találunk információkat bécsi leveleiből. Ezen információk egy részét Malonyai Dezső közli Ligeti Antal közléseire hivatkozva. Ezekböl az információkból is egy olyan mủvész képe bontakozik ki, aki nehezen hajolt meg az akadémia szabta szabályok előtt. ${ }^{360}$ Munkácsy Mihály sajátos természete nem türte a szabályokat, amit Rahl tanítási módszerének és saját fiatalkori tapasztalatainak köszönhetően nem jól tolerált. Mindketten fontos szerepet juttattak az egyéni, müvészet terén alkotott elképzeléseiknek. Munkácsy is eltürte mégha nehezebben is ezeket az akadémia szabta szabályokat, de amint lehetett, a saját elképzeléseit jutatta érvényre. ${ }^{361}$

Munkácsy, akárcsak a fiatal Rahl, az akadémiai órákon kívül otthonában is másolt és önálóan komponált. ${ }^{362}$ Mayer mondatait idézve: „Ez a állapot lesz a kulcsa az (Rahl) sajátosságainak, előnyeinek és hátrányainak." ${ }^{363}$ Rahl professzor egy művésznövendékekről szóló írásában ezen szabad utat járó tanítványait „Naturtalent”ként, azaz természet adta tehetségként aposztrofálta. Az általa megfogalmazott

\footnotetext{
${ }^{360}$ Malonyai (1898), 74.o.: „Addig is voltak kellemetlenségei az akadémián elég gyakran. Tanárai , -mint Ligetinek beszélte, hazatérve Rahl halála után Bécsböl,-leginkább azért haragudtak reá, mert nem fogadta meg tanácsukat, a munkálatain tett javításaikat távozásuk után menten eltörülte s újból csak úgy csinálta , a mint ö gondolta jónak. [...] És a „Wilder Ungar“-t,- így nevezték el. - azért hagyták is tovább dolgozni.” ${ }^{361}$ Malonyai (1898), 76.o.: „Könnyü neked, te könyvekböl tanulsz, te elötted minden készen ott van, de én hol tanuljak? Mit tanuljak? Az akadémiában egy modellen egy hétig kell piszmogni, szépen ki kell árnyékolni, kockázva vagy pontozva. És ezt a nyomorék rajzolást két esztendeig kell folytatni. Barátom, hidd el nekem, kutyát se ér ez így!

-Hát járj a magad lábán.

- Nem is a másén! - vágta komolyan vissza."

${ }^{362}$ Mayer (1882), 3.o.: ,,[...] Rahl stand dem nach nur auf dem Boden der Akademie, bis Anregung aber brachte er meist vom Hause mit und schöpfte sie zum größten Theile aus sich selbst, und so ward er früh und blieb zeitlebens Autodidakt. Dieser Umstand wird zum Schlüssel vieler seiner Eigenthümlichkeiten, seiner Vorzüge und Mängel.“

${ }^{363}$ Mayer (1882), 3.o.:,,Dieser Umstand wird zum Schlüssel vieler seiner Eigenthümlichkeiten, seiner Vorzüge und Mängel.“
} 
kategóriába sorolandó a fiatal Munkácsy Mihály is. ${ }^{364}$

\subsection{Munkácsy Mihály Bécsből való távozásának okairól}

Az akadémiai papírok azt az információt is tartalmazzák, hogy Munkácsy 1865. július 17- én a tandíj befizetésének elmaradása miatt (400 Fl.) a Bécsi Képzőművészeti Akadémia névsorából töröltetett. ${ }^{365}$ A Munkácsy monográfiák Munkácsynak a Bécsi Akadémiáról való távozását azzal indokolják, hogy ennek financiális okai voltak. A festő nem tudta kifizetni a tandíjjat. ${ }^{366,367,368}$ Mindemellett bécsi professzoraival való nézeteltérése miatt kényszerült azt elhagyni. Ennek a következtetésnek a levonására azért kerülhetett sor, mert nem ismerik Munkácsy ezen bécsi időszakából származó leveleit, illetve az akadémiai beiratkozási papírjait! Munkácsy valóban nem fizette be a tandíjat, de nem a finanszírozásból fakadó problémái miatt! Munkácsy Mihály azon egyszerü ok miatt nem tett ennek eleget fizetési kötelezettségének, mert a későbbiekben nem kívánt a Bécsi Képzőművészeti Akadémia hallgatója maradni! A monográfiák feltételezése, mely levéltári anyagokkal nincs alátámasztva, és Munkácsy elhatározása közötti különbség meglehetősen nagy. Az első ok, ami miatt Munkácsy nem akart

\footnotetext{
${ }^{364}$ Mayer (1882), 22.o., Rahl levele Dr. Heidernek: „,...] akik gyakran nem képesek tanítani, mivel általában egyoldalúak és a vele született képességüket nem tudják továbbadni. A született tehetség a müvészi lét elengedhetetlen kelléke, de mint olyan, nem lehet tanítani és továbbadni. Egy született tehetség öntudatlanul cselekszik és igy nem tud tanítani. Egy müvész, aki tud tanítani, sokat tanult és tapasztalt [...] és az ember csak azt tudja továbbadni, amit strukturáltan és tapasztalatok alapján hoz létre."

${ }^{365}$ Universitätsarchiv der Akademie der bildenden Künste.Matrikel vom Jahr 1864-1865. I. Semester. Matrikel vom Jahr 1865-1866.: „Am 17. Juli 1865 wurde Munkácsy aus der Reihe der Malerzöglinge der Wiener Akademie gestrichen, weil er laut Matrikel das Schulgeld (400) nicht bezahlte.“

${ }^{366}$ Bakó (2012), 10.o.

${ }^{367}$ Bakó (2008), Munkácsy Mihály, 10.o.

${ }^{368}$ Perneczky (1970), Munkácsy, 7.o.
} 
Bécsben maradni, Karl Rahl professzor 1865. július 9-én bekövetkezett halála volt. A második ok, ami Munkácsy bécsi leveleiből kirajzolódik, hogy egy Bécsben kiállított Ludwig Knaus ${ }^{369370}$ festmény olyan elementáris erővel hatott a fiatal festőre, hogy az további tanulmányait csak Knaus mellett tudta elképzelni. Ezért Rahl halála után Knaushoz Berlinbe szeretett volna utazni. ${ }^{371,372}$ Knaus kiállított festményét a „der Gaukler (vagy a le Saltimbanque, a szemfényvesztő) a korabeli bécsi sajtó is elismerően méltatta. A „Wiener Abendpost“ terjedelmes cikket közölt a képről, amit P. Käfer út mükereskedésében állítottak ki. ${ }^{373}$ A cikk szerzője egy meg nem nevezett festőre, mint szakértőre hivatkozva elsimerően nyilatkozott a német festő művéről. ${ }^{374}$ Munkácsy

\footnotetext{
${ }^{369}$ Ludwig Knaus (1829-1919), német festő. In: Zádor Anna (1962), Magyar művészet 1800-1945. Végvári Lajos: Magyar művészet az elnyomatás idején (1849-1867), 189., 490. o.

${ }^{370}$ Wiener Abendpost, Beilage der Wiener Zeitung. 1865.-Nr. 81. Samstag, 1865. április 8., 322.o.

${ }^{371}$ OSZK.-Kézirattár. Levelestár, Munkácsy. Mihály levele Ligeti Antalnak, 22. sz. levél.

${ }^{372}$ OSZK.-Kézirattár. Levelestár, Munkácsy Mihály levele Ligeti Antalnak, 6. sz. levél, 1865. október 20., Gerendás.: „A mire már Pesteni (?) találkozásunk alkalmával megkértem kedves Ligeti úrat most ismételve kérem szíveskedjék tehát Knausnak Berlinbe írni az iránt, hogy biztosra mehessek, t. i. hogy van e hely nála s. s. b. mert én, ha a jövö hó 15 kén valamelyik képemet el adnám, s az árát megkapnám rögtönmennék.
}

Most van benyújtva egy folyamodványom müvészi ösztön díjért, a mit biztosan tudok, hogy nem nyerem el [...]fonó lány cimü képem 2150 forintba , ennyi pénzem tehát már van, és még a többiröl is - úgy gondolkodtam, hogy még két képet küldtem, egyik ábrázolja a parasztok est ebédjét, szabadban a pusztán, a másik pedig egy búsuló betyárt [...].

Ezeket szeretném valahogy a mü egyesületnél eladni hogy a még hiányzó összeget ki kapjam belöle.“

${ }^{373}$ Wiener Abendpost, Beilage der Wiener Zeitung. 1865.-Nr. 81. Samstag, 1865. április 8., 322.o.

${ }^{374}$ Wiener Abendpost, Beilage der Wiener Zeitung. 1865.-Nr. 81. Samstag, 1865. április 8., 322.o.: „, Das feinste Verständniß der Form und Farbe, umgezwungen und naturwahr in Bewegung und Zeichnung der einzelnen Gestalten, treffliche Gruppiereung und Vertheilung der Licht- und Schattenmassen, nirgens ein Anlehnen an diesen oder jenen Meister; nirgends ein Coquettieren mit Farben oder wohlfeiler Effecthascherei - kurz, auch der raffinirteste Nörgler und Haarspalter wird veranlaßt, seine kritische Sonde bei Seite zu legen und einzustimmen in den Anruf: das ist einmal ein echtes, vollendetes Kunstwerk! 
Mihály Ligeti Antalhoz írt levelében ugyancsak nagy elismerésének adott hangot. ${ }^{375}$, 376 Knaus művészete iránti lelkesedése ugyancsak megmutatkozik Engel Gyulához íródott leveleiben is, amik szintén alátámasztják azt a tényt, hogy Munkácsy saját elhatározásából, önszántából és nem a pénz szűke miatt kényszerült elhagyni a Bécsi Képzőművészeti Akadémiát! Levelében tervezett utazásának financiális kereteit is megemlíti, miszerint „Fonó lány“ címü festményének árából szeretné Berlinbe való utazását fedezni. ${ }^{377}$

\footnotetext{
${ }^{375}$ OSZK.-Kézirattár, Levelestár. Munkácsy Mihály levele Ligeti Antalnak, 4. sz. levél, 1865.április 15.: „[...] Most egy igen kedves müélvezetben részesülök Bécsben a midön s. i. nézem a jeles Knaus legujabb remek müvét, a mely itt egy könyv ......(?) mükereskedésben van kiállítva valóban meg voltam hatva midön megláttam a müvet, s percnyire mint egy elszomorodtam mert láttam mily magas fiok az, a mit müvészetnek nevezhetünk - ám de a következö percben lelkesülve vevém kezembe az ecsetet küzdeni a müvészetért vagy el esni érte. - elgondolám, hogy az út tán elöttem is meg nyilhatik melyjek e célt legalább meg közelíthetem [...].
}

Kedves Ligeti úr bizonyára tudni fogja, hogy a kiállított mü egy - a parasztok elött csodának tünö büvészt ábrázol, én nem írom itt részletesen le mert jobban leírják azt mások a mit Ligeti úr már bizonyosan olvasott.“

${ }^{376}$ OSZK.-Kézirattár. Levelestár.Munkácsy Mihály levele Ligeti Antalnak, 5. sz. levél „,[...] Tisztelt Ligeti ur, tehát nem hallott a Knaus képröl semmit, pedig nagyszerü abrazol egy sarlatan büvészt, aki a publikum között egy jámbor paraszt embernek kalapja alol kanari madarakat röpit ki [...]. A kép fö oldala, a publikumban elöidézett hatást ábrázolja, mégpedig nagyon szépen [...] van még aztán sok minden szép ezen képen amit csak látni kell különben Ligeti úr azt képzelheti miután ösmeri Knaus müveit.“

${ }^{377}$ OSZK.-Kézirattár. Levelestár. Munkácsy Mihály levele Ligeti Antalnak, 6. sz. levél, 1865. október 20., Gerendás.: „A mire már Pesteni (?) találkozásunk alkalmával megkértem kedves Ligeti úrat most ismételve kérem szíveskedjék tehát Knausnak Berlinbe írni az iránt, hogy biztosra mehessek, t. i. hogy van e hely nála s. s. b. mert én, ha a jövö hó 15 kén valamelyik képemet el adnám, s az árát megkapnám rögtönmennék.

Most van benyújtva egy folyamodványom müvészi ösztön díjért, a mit biztosan tudok, hogy nem nyerem el [...]fonó lány cimü képem 2150 forintba , ennyi pénzem tehát már van, és még a többiröl is - úgy gondolkodtam, hogy még két képet küldtem, egyik ábrázolja a parasztok est ebédjét, szabadban a pusztán, a másik pedig egy búsuló betyárt [...].

Ezeket szeretném valahogy a mü egyesületnél eladni hogy a még hiányzó összeget ki kapjam belöle.“ 
Miután Munkácsy akadémiai szemeszterének a végeztével visszatért Pestre, Ligeti Antal segítségét kéri, hogy írjon Berlinbe Knausnak, hogy az ő útmutatásával tanulhasson. ${ }^{378}$ Terveit csak később sikerült megvalósítania. A pesti Rahlianerek és Ligeti Antal a Müncheni Akadémián való továbbtanulást tanácsolta Munkácsynak. Aki megfogadta ezt, ${ }^{379}$ bár a Münchenböl küldött leveleiben is, amikor már a híres Kaulbach $^{380}$ tanítványa volt, akkor is a Knaus mellett való tanulásának terve foglalkoztatta. ${ }^{381}$

Müncheni tanulmányai után Düsseldorfba utazott és beiratkozott az ottani akadémiára. Ezen németországi időszakában ismerhette meg Ludwig Knaust. Az ismerettséget barátság követte, amiről Düsseldorfban kelt levelei is tanúskodnak. ${ }^{382}$

${ }^{378}$ OSZK.-Kézirattár. Levelestár.Munkácsy Mihály levele Ligeti Antalnak, 6. sz. levél, 1865. október 20., Gerendás. „A mire már Pesteni (?) találkozásunk alkalmával megkértem kedves Ligeti úrat most ismételve kérem szíveskedjék tehát Knausnak Berlinbe írni az iránt, hogy biztosra mehessek, t. i. hogy van e hely nála s. s. b. mert én, ha a jövö hó 15 kén valamelyik képemet el adnám, s az árát megkapnám rögtön mennék.

Most van benyújtva egy folyamodványom müvészi ösztön díjért, a mit biztosan tudok, hogy nem nyerem el [...] fonó lány cimü képem 2150 forintba , ennyi pénzem tehát már van, és még a többiröl is - úgy gondolkodtam, hogy még két képet küldtem, egyik ábrázolja a parasztok est ebédjét, szabadban a pusztán, a másik pedig egy búsuló betyárt [...].

Ezeket szeretném valahogy a mü egyesületnél eladni hogy a még hiányzó összeget ki kapjam belöle.“ ${ }^{379}$ OSZK.-Kézirattár. Levelestár. Munkácsy Mihály levele Ligeti Antalnak, 22. sz. levél, 1868.München.

${ }^{380}$ Wilhelm von Kaulbach (1804-1874), német festő. In: Zádor (1962), 140.o., 490.o.

${ }^{381}$ OSZK.-Kézirattár. Levelestár. Munkácsy Mihály levele Ligeti Antalnak. 15. sz. levél, 1867. München: „[...] Most is tartom magam Kaulbach azon mondásához, hogy a genre képekben nem kell ugyan „, fél istennek lenni a figuráknak. Hanem „ egy sugara az istenségnek keresztülvonuljon azokon“ én pedig azt a jelen század szülte genre képek hoz (?) csak Knauszban talalom.

Tehát pártolom Ligeti ur azon mondatát hogy minél hamarabb Knauszhoz, mégpedig Berlinbe mert ö ott van, az az a nyár folyamán Párizsban, min azt Schlaik jo barátja mondta, ö azt is mondja hogy Knausz igen szives ember mindenestetre sokan nyernék mellette.

${ }^{382}$ OSZK.-Kézirattár, Levelestár. Munkácsy Mihály levele Ligeti Antalnak, 16. sz. levél, 1867. június 14., 22. sz. levél, 1868. München. 23. sz. levél, 1868, Düsseldorf. 24. sz. levél, 1868, Düsseldorf. 25. sz. Levél, 1868. december 7., 26. sz. levél, 1868. december 25., 27. sz. levél, 1869. január 10., 28. sz. levél, 
Összefoglalva, Munkácsy levelei arról tesznek tanúbizonyságot, hogy a Bécsi Képzőmüvészeti Akadémiát nem azért hagyta el, mert a tandíjat nem fizette be, azaz pénzhiánnyal küzdött. Ez az elhatározása belülről fakadt. Karl Rahl halála után nem volt kiért, miért maradnia, unta az ottani akadémiát. Ezt csak megerősítí egy 1869-ből származó levele. ${ }^{383}$ Munkácsy Mihály leveleit áttekintve művészeti pályafutására egyik legnagybb befolyással bíró festőjének Ludwig Knaus nevezhető.

1869, 29. sz. levél, 1869. április 20., 30. sz. levél, 1869 Düsseldorf. 32. sz. levél, 1869, Düsseldorf. 35. sz. levél, 1870 Düsseldorf. 36. sz. levél, 1870 Düsseldorf.

383 OSZK.-Kézirattár, Levelestár. Munkácsy Mihály levelei Ligeti Antalnak. 28. sz. levél. 1869. Düsseldorf.: ,[...], végre 1865.-ben az ö ajánlása kísért Bécsbe, hol egy évi tartózkodásom után, az ottani akadémiát megunva, ismét vissza kerülvén Pestre hogy némi pénz magra tegyek szert, mellyel Münchenbe zarándokolhassak...“ 


\section{Ludwig Knaus}

\subsection{Ludwig Knaus múvészetének súlya Munkácsy Mihály útkeresésében $^{384}$}

Munkácsy Mihály mủvészi pályájának alakulására meghatározó jelentőséggel bírt a Bécsben kiállított Ludwig Knaus által festett festmény, mely egy bűvészt ábrázol. A hatás elementális erővel hatott a fiatal müvésznövendékre, kijelölve annak müvészi útkeresésében a realista stílus felé vezető utat. ${ }^{385,386}$ A Munkácsy Mihályról íródott monográfiák tényként kezelik ezt a fontos momentumot a festő életében, de levéltári dokumentáció alátámasztása nélkül. Tanulmányai során pedig nem követik nyomon ezt az ösztönző, művészeti pályafutása szempontjából meghatározó momentumot. Rahl temetése után 1865 júliusában Munkácsy visszatért Pestre. ${ }^{387}$ Ezen időszak alatt mélyült el a barátsága Ligeti Antallal. Az ő személyében atyai barátra talált, akinek véleménye fontos szerepet játszott a fiatal festő életében. Szerepe külföldi tanulmányai alatt sem csökkent, hanem egyre nőtt, hiszen Ligeti is Ludwig Knaus baráti köréhez tartozott. Munkácsy mủvészi útkeresésének további célja és mozgatórugója a Berlinbe, Knaus műtermébe való út kikövezése volt. Minél előbb a német festő útmutatása szerint

\footnotetext{
${ }^{384}$ Polenyák Ivett (2012), Ludwig Knaus művészetének súlya Munkácsy Mihály útkeresésében. In: Strausz Péter, Zachar Péter Krisztián ed. (2012), Történelmi nemzet és identitás. 141-144.o.

${ }^{385}$ Wiener Abendpost, Beilage der Wiener Zeitung. 1865.-Nr. 81. Samstag, 8. April. 322.o.

${ }^{386}$ A Munkácsy Mihályról íródott monográfiák, tényként kezelik ezt a fontos momentumot a festő életében, de levéltári dokumentáció alátámasztása nélkül. Tanulmányai során pedig nem követik nyomon ennek ösztönző, müvészeti pályafutása szempontjából meghatározó momentumot. Bakó, (2008), 14.o.,

${ }^{387}$ Pesti Napló, "Különfélék" c. rovat, Rahl beteg 1865. július 5., július 8., július 12., július 14., július 15., Rahl kiállításról, 1865. augusztus. 24., október 22.
} 
szerette volna továbbfejleszteni festői tudását. ${ }^{388} 1865$ októberében kelt levelében arra kérte Ligetit, hogy segítsen festményei eladásában, azok kisorsoltatásában, mert ennek árából szerette volna Berlinbe való utazásának költségeit előteremteni. ${ }^{389}$ Mindemellett, Ligeti tanácsait megfogadva, igyekezett festői tudását előszőr a müncheni, másrészt a Düsseldorfi Művészeti Akadémián elmélyíteni. Ezen tanulmányai előtt ugyan szeretett volna Párizsba utazni, hiszen Knaus éppen oda tette át székhelyét, de ismételten Ligeti Antal tanácsára hallgatott. ${ }^{390}$ A Müncheni Akadémián Alexander Wagner ${ }^{391}$ és Wilhelm Kaulbach útmutatásai szerint festette meg képeit. Müncheni tartózkodásának finanszírozását eladott képei bevételéből igyekezett biztosítani. Az értékesítésben Than Mór segítette. A Diana teremben ${ }^{392}$ állították ki képeit, melyek gyorsan vevőkre

\footnotetext{
${ }^{388}$ OSZK.-Kézirattár, Levelestár. Munkácsy Mihály levele Ligeti Antalnak. 6. sz. levél, 1865. október 20., Gerendás: „A mire már Pesteni (?) találkozásunk alkalmával megkértem kedves Ligeti úrat most ismételve kérem szíveskedjék tehát Knausnak Berlinbe írni az iránt, hogy biztosra mehessek, t. i. hogy van e hely nála s. s. b. mert én, ha a jövö hó 15 kén valamelyik képemet el adnám, s az árát megkapnám rögtön mennék.
}

Most van benyújtva egy folyamodványom müvészi ösztön díjért, a mit biztosan tudok, hogy nem nyerem el [...]fonó lány cimü képem 2150 forintba, ennyi pénzem tehát már van, és még a többiröl is - úgy gondolkodtam, hogy még két képet küldtem, egyik ábrázolja a parasztok est ebédjét, szabadban a pusztán, a másik pedig egy búsuló betyárt [...].

Ezeket szeretném valahogy a mü egyesületnél eladni hogy a még hiányzó összeget ki kapjam belöle.“

OSZK.-Kézirattár. Levelestár. Munkácsy Mihály levele Ligeti Antalnak. 25. sz. levél, 1868. december 26.

${ }^{389}$ OSZK.-Kézirattár. Levelestár. Munkácsy Mihály levele Ligeti Antalnak, 6. sz. levél, 1865. október 20. Gerendás.

${ }^{390}$ OSZK.-Kézirattár. Levelestár, Munkácsy Mihály levele Ligeti Antalnak. 11. sz. levél, 1867. április 8.: „Ligeti urnak a tanácsai még eddig mindég használtak Igy az utolso is, mely szerint nem Párizsba hanem ide jöttem, hol egy szobol mindenemet feltalaltam, amire oly regen vágytam Müvészetem iránti szeretetem és lelkesültségem folyton nö. Az alkalom melyet mos élek, nagyon felvillanyoztott ugy, hogy inkább éhen halnék,mint sem tanulmányaimat bevégzése elött haza mennék.“

\footnotetext{
${ }^{391}$ Sándor (Alexander) Wagner (1838-1919), magyar festő.

${ }^{392}$ Pesten a mai Roosevelt téren állt a Diana fürdő épülete, amely helyt adott a Pesti Műegylet keretében rendezett müvészeti kiállitásoknak.
} 
találtak: a "Fonó lány"-t 215 forintért, "Parasztok estebédje" és a "Búsuló betyár" címü képek pedig 200-200 forintért keltek el. ${ }^{393}$ Továbbá portrékat is festett rokonai körében. ${ }^{394}$ Ligeti Antal állhatott a Fővárosi Lapok azon kezdeményezése mögött, hogy Munkácsy számára gyüjtést rendezzenek, hogy abból további külföldi tanulmányait fedezni tudja, amiről nagybátyja. Erröl Reök István és a fiatal müvésznövendék is megemlékezett leveleiben. ${ }^{395,396}$ 1866-ban már boldogan értesíti barátját Münchenbe való megérkezéséről. ${ }^{397}$ Wagner barátságosan fogadta Munkácsyt és a betelt osztálylétszám ellenére tanítványául fogadta. ${ }^{398}$

A kiegyezés pozitív hatásai a müvészet terén is érezhetőek voltak. Eötvös Józsefnek köszönhetően állami ösztöndijakért lehetett folyamodni, ami nagymértékben megkönnyítette a külföldön továbbtanulni vágyó művésznövendékek helyzetét. A privát mecenatúra helyét az állami vette át. 1862-ben Székely Bertalan a következő

\footnotetext{
${ }^{393}$ OSZK.-Kézirattár. Levelestár. Munkácsy Mihály levele Ligeti Antalnak. 6. sz. levél, 1865. október 20., Gerendás, 8. sz. levél, 1865. december 11.

${ }^{394}$ Czeglédi ed. (1976), 11.o. ,[...] Steiner tehát nem hogy segített volna, hanem magát segítette általad olcsó képekhez jutnia, igen szép, igen jellemzö rá nézve. Engen egyébiránt ez nem lep meg.“

${ }^{395}$ Czeglédi ed. (1976), 12.o.: „,...] Gyüjtenek számodra? Jobb volna ugyan, ha te gyüjtenél más számára, de kivételképp ígyis jól van.“

${ }^{396}$ OSZK.-Kézirattár. Levelestár. Munkácsy Mihály levele Ligeti Antalnak. 9. sz. levél, 1866. november 20.: ,[...]Valaki küldött ide egy osmerösömnek egy szám fövárosi lapokat a melyben olvasom, hogy számomra gyüjtést szándékoznak rendezni Pesten. Szép szándék - - - bárcsak ne veszne ki csírájában. Különben én azt hiszem, hogy Ligeti Urtól jön ez a dolog azért tehát tudom, miszerint ha a szikra megvan, lesz belöle tüz.“

${ }^{397}$ OSZK.-Kézirattár. Levelestár. Munkácsy Mihály levele Ligeti Antalnak, 9. sz. levél, 1866 november 20.: „Itt vagyok! [...] azonban, jutottam légyen bárhogy ide csakhogy itt vagyok, és ugy gondolom továbbra is, legyek bárhogy itt, csakhogy itt lehessek.“

${ }^{398}$ OSZK.-Kézirattár. Levelestár. Munkácsy Mihály levele Ligeti Antalnak. 9. sz. levél, 1866. november 20.: ,[...] Sok sohajtozás után valahára el értem vágyam, eszményképem a külföldi tanulmányozást. S most itt vagyok Münchenben, fel véve az akadémián.

[...]Itt már felvetettem magam az akadémián, éppen a Wagner osztályába eleinte egy kissé nehezen ment vele, mert szük a hely, hanem aztán tágított még is. És kidobott egy német gyereket ö azt a helyet szánta nekem.“
} 
gondolatokat fogalmazta meg az állam lehetséges szerepéről: az államnak színvonalas művészekre és nem akadémiai tanulókra van szüksége. Vagyis az állami támogatást a már kitanult müvészekre is ki kell terjeszteni. ${ }^{399}$

\subsection{A kiegyezés és annak pozitív hatásai a magyar müvészeti életre}

Az 1867-es kiegyezésnek köszönhetően Az Osztrák-Magyar Monarchia gazdasági élete fellendült. Elsősorban a Balkánra irányuló export következtében a Magyar Királyság területén jelentős tőkefelhalmozás történt. ${ }^{400}$ Mindez a magyar müvészeti oktatásra és a magyar művészeti életre egyaránt hatást gyakorolt Eötvös József vallás és oktatási miniszternek köszönhetően. Az állam mecénásként jelent meg a privát és az egyházi támogatók mellett, nem csak ösztöndíjak, hanem állami megbízások formájában is igyekezett gondoskodni csekély számú hazai müvészeiről. Az állami támogatásoknak köszönhetően a külföldi akadémiákon ${ }^{401}$ egyre több tehetséges magyar müvésznövendék ${ }^{402}$ tanulhatott, hiszen az országnak még mindig nélkülöznie kellett a művészeti oktatást elősegítő iskolát, akadémiát. A művészeti képzést elősegítő, állami politikának köszönhetően a magyar müvészek egyre rangosabb nevet szereztek a nemzetközi müvészéletben, melynek következményeként a magyar társadalomban

\footnotetext{
${ }^{399}$ Wiener Stadt- und Landesbibliothek, Handschriftenabteilung I. No. 21. 840. Bertalan Székely, München, 24. Juni 1862.:

„Az államnak jó müvészekre és nem akadémiai tanoncokra van szüksége. Ezért nemcsak a kezdetről, hanem a folytatásról is gondoskodnia kell-nem logikus, hogy valakitől akkor vonják meg a támogatást, amikor éppen kezd kiteljesedni kezd.“

${ }^{400}$ Kövér György (1998), A piacgazdaság kiteljesedése. In: Gergely András ed., A 19. századi magyar történelem 1790-1918., 343-374.o., Hanák Péter (1975), Magyarország az Osztrák-Monarchiában. Túlsúly vagy függőség. In: Hanák Péter ed., Magyarország a Monarchiában, 291-339.o.

${ }^{401}$ Gill Perry-Colin Cunningham (1999), Academies, Museums and Canons of Art. New Haven-London.

${ }^{402}$ Lyka Károly (1912), Müvészet. Magyarok Müncheni Müvészeti Akadémián 1824-1890, 178-188.o., Kárai Petra, Veszprémi Nóra (2009), München magyarul. Magyar Müvészek Münchenben 1850 - 1914.
} 
elfoglalt helyük is szembetűnően emelkedett. ${ }^{403}$ Munkácsy Mihály az elsők között volt, akinek külföldi tanulmányait az állam ösztöndíjjal támogatta. A Müncheni Akadémián végzett tanulmányaira 800 forint állami támogatást kapott, amely odaítélésében barátai, Telepy Károly, Ligeti Antal és Than Mór is segítségére voltak. ${ }^{404}$ Eötvös József ezen megnevezett művészbarátainak köszönhetően, tisztában volt azzal, hogy a hazai mủvészképzés oktatási intézményes kereteinek a megteremtése elengedhetetlen, ha az ország be akar kerülni az nyugat-európai, élvonalbeli művészéletbe. Ezen mintakövetésre csak 1871 után kerülhetett sor, miután megalakult a Magyar Királyi Országos Mintarajztanoda és Rajztanárképezde. ${ }^{405}$

Az állami ösztöndíj pályázatokhoz egy vázlatot is be kellett nyújtani. Munkácsy már a Müncheni Akadémia növendékeként a „Pesti árvíz“406 című vázlatát mellékelte. Ezt professzorai, Wilhelm Kaulbach és Alexander Wagner pozitív ajánlásai és akadémiai bizonyítványa egészítette ki. Munkácsy Ligeti Antalhoz írt leveléből azt is megtudhatjuk, hogy Karl Theodor von Piloty is látta a festményt, de ő javításokat javasolt. Wagner barátságát viszont ennek a képnek köszönhette Munkácsy. ${ }^{407}$

Munkácsy a levelében láthatólag nem vette komolyan Karl Theodor von Piloty bírálatát. $\mathrm{Az}$ is egyértelmü, hogy Munkácsy biztos volt a dolgában, amit a többi müncheni professzor véleménye is alátámasztott. Így nehezen felismerhető Munkácsy azirányú törekvése, hogy Karl Theodor von Piloty közelébe kerüljön, mint ahogy azt néhány művészettörténész és Munkácsy monográfia szerzője állítja. Müncheni Akadémiai

\footnotetext{
${ }^{403}$ Szívós Erika (2009), A magyar képzőmủvészet társadalomtörténete. 1867-1918.,

${ }^{404}$ Malonyai (1898), 87. o.

${ }^{405}$ Szívós Erika (2009), A magyar képzőművészet társadalomtörténete. 1867-1918., 47.o.

${ }^{406}$ A festmény címe „Pesti árvíz“. Munkácsy azonban leveleiben a következő címmel látta el „Pestvárosi 1838 évi árvíz““

${ }^{407}$ OSZK.-Kézirattár, Levelestár, Munkácsy Mihály levele Ligeti Antalnak. 10. sz. levél. (Keltezés nélküli!): „,...] Kaulbachnak a tetszését ami a kompoziciós szint illeti megnyertem. - Piloti azt akarta volna, hogy több vizet az-az hogy csupa vizet csináltam volna, és mindenféle uszkáló kutyaházakat fessek és minél kevesebb figurát, szóval azt mondta, hogy ez históriás[...]Hanem azt hiszem inkább legyen ez históriás és ilyen tárgy, mint nagyon is kisszerü.[...]Vagner egy ujabb idö óta igen jó emberem lett, már többször meglátogatott [...] barátságot amit nem vártam volna az ö hideg természetétöl.“
} 
professzorain kívül nagy hatással volt Munkácsyra az életképeket festő Franz Adam ${ }^{408}$, akit 1867-ben ismert meg. A baráti szálak ismét csak Pestre nyúltak vissza, hiszen Ligeti Antal baráti köréhez tartozott e német müvész is. ${ }^{409}$ Munkácsy jól érezte magát Münchenben, professzorai jóindulatát a magáénak tudhatta. Mindemellett a Ludwig Knaushoz való utazását tervezgette. ${ }^{410}$ Egy ösztöndíjat pályázott meg, amihez Kaulbach jó akadémiai bizonyítványt biztosított, ami tehetségének elismerése is volt. ${ }^{411} \mathrm{Az}$ állami támogatás elnyeréséig Munkácsy festményei eladásából és a Magyar Képzőművészeti Társulat támogatásából élt. Amikor a Társulat elfogadta azt a kezdeményezést, hogy fiatal, tehetséges magyar mủvésznövendéket patronáljanak, Than Mór a müncheni növendéket, Munkácsyt ajánlotta azzal a kikötéssel, hogy ennek fejében fessen egy képet a Társulatnak. ${ }^{412}$ Erre szüksége is volt a festőnek. ${ }^{413}$ Sajnos a Magyar Művészeti Egylet is gyakran küzdött pénzhiánnyal, így a támogatás is csak rendszertelenül érkezett Münchenbe, ami gyakran komoly pénzügyi nehézségekbe sodorta a festőt. ${ }^{414} \mathrm{Az} 1867$.

\footnotetext{
${ }^{408}$ Franz Adam (1815-1886), német genre festő és litográfus.
}

${ }^{409}$ OSZK.-Kézirattár, Levelestár, Munkácsy Mihály levele Ligeti Antalnak. 19. sz. levél, 1867. december 6., München.:"Nálunk már beállottak a téli foglalkozások. Ádámnál nagyon jól érzém magam, s dolgozom."

${ }^{410}$ OSZK.-Kézirattár, Levelestár, Munkácsy Mihály levele Ligeti Antalnak. 15. sz. levél [1867 München]: A levél keltezése és helye a szerző kutatómunkájának eredménye.)

${ }^{411}$ OSZK.-Kézirattár, Levelestár, Munkácsy Mihály levele Ligeti Antalnak. 11. sz. levél, 1867. április 8.: „Szükségem van egy tehetségröl szóló bizonyítványra, amelyet ezuttal töle nyerek. A tehetségi bizonyítvány t. i. mellékletül szolgálana egy most megürült Stipendium beadandó folyamodványhoz. [...] s Kaulbachnak amint mondám tetszett, töle és az itteni akadémiától kapok jó bizonyítványt,“

${ }^{412}$ Malonyai (1898), 78.o.: „,...]Than Mór azt is indítványozta, hogy Munkácsynak is adnának húsz forint havi segélyt, vagy tíz hónapon át, „elöleg“ címen s azzal a kikötéssel, hogy ez összeg fejében majd fessen egy képet a Társulatnak. Than indítványát Ligeti is melegen pártolta és a választmány el is fogadta.”

${ }^{413}$ OSZK.-Kézirattár, Levelestár, Munkácsy Mihály levele Ligeti Antalnak. 11. sz. levél, 1867. április 8.: „[...] nappal tanulmányokat festek Vagnernél estve komponalok s.t.b. és boldog vagyok, noha most kértem Telepit hogy kuldjon 15 f.tot mert eleinte dragan eltem és most letisztaztam magam az adossagbol“"

${ }^{414}$ OSZK.-Kézirattár, Levelestár, Munkácsy Mihály levele Ligeti Antalnak. 13. sz. levél, 1867. május 9.: „[...] a kellnernök száma most már négy, ezek közül egy-kettö mindennap hozzám jön tisztelegni és mindennap hiába. Ha a mostani kellnernö is elmegy, akkor lesz öt látogatóm [...]“ 
július 27-i ösztöndíj ebből a nehéz helyzetből mentette meg, a 800 forintot szeptember 2-án utalták ki a festő nevére. ${ }^{415}$

\subsection{A müncheni múvészek hatása Munkácsy múvészetére}

A müncheni professzorain és Adam mütermén kívül Munkácsy Mihály Münchenben kelt leveleiben három német festő nevéről tett említést: Liell, Leibl ${ }^{416}$ és Eduard Schleich. ${ }^{417}$ Münchenben pezsgőbb volt a művészélet, mint Bécsben. A várost a korabeli Európa egyik kulturális központjaként tartották számon. A müvészeti irányzatok képviselői békében éltek egymás mellett. A realista stílust követő festőmüvészek közül Munkácsy, aki Ludwig Knaus mủveinek hatása alatt állt, egyikőjük müvészetét sem találta követésre méltónak. Ligeti Antalhoz íródott egyik levelében ezt pontosan megfogalmazta. ${ }^{418}$ Münchenben festett, az „Isaszegi csatatér“ vagy a "Szénásszekér" című müveinek témái a hazai, nemzeti kultúra megelevenedését mutatják, szemben az akadémia Karl Piloty által képviselt müvészeti iránnyal, a történeti festészettel. ${ }^{419}$ Munkácsy a város képtárának, a Pinakothékának a termeit is gyakran kereste fel másolás céljából. ${ }^{420} \mathrm{Az}$ időszakos tárlatokat is megtekintette, melyek a Müncheni Müvészeti Egylet keretében kerültek megrendezésre. ${ }^{421,422}$

\footnotetext{
${ }^{415}$ Malonyai (1898), 87.o. Az összeget “6577“ szám alatt utalványozták az 1867-es évből és szeptember 2.-án "8963" szám alatt

${ }^{416}$ Wilhelm Leibl (1844-1900), német, realista festő.

${ }^{417}$ Eduard Schleich (1853-1893), német festő.

${ }^{418}$ OSZK.-Kézirattár, Levelestár, Munkácsy Mihály levele Ligeti Antalnak. 15. sz. levél, 1867. München.: „[...] hanem genre piktort nem találok kedvemre valót, dacára annak hogy kocsi számra vannak, de mind oly annyira realistikus irányú hogy nem tartom célszerünek utanok haladni.“

${ }^{419}$ Lyka Károly (1951), Magyar müvészélet Münchenben. 24-25.o.

${ }^{420}$ OSZK.-Kézirattár, Levelestár, Munkácsy Mihály levele Ligeti Antalnak. 12. sz. levél, 1867. április 8.: „Sok mindenféle festenivaló valo tárgy am van, csak gyözném, azonban szeretnék valamit másolni a
} 


\subsection{A Düsseldorfi Múvészakadémia, avagy Ludwig Knaus nyomában}

1868-ban Munkácsy Mihály második alkalommal nyert állami ösztöndíjat. Ennek köszönhetően financiális biztonságban élt és minden idejét a festőművészetnek szentelhette. Eötvös József, aki Ligeti Antalnak köszönhetően rokonszenvet táplált Munkácsy irányába, sajnos már nem élhette meg, hogy választásának helyességét az idő igazolja. Amikor Munkácsy müvészetének híre bejárta Európa nagyvárosait, Eötvös özvegye levélben emlékezett meg férje pártfogoltjáról és annak egykori döntésének helyességéről ${ }^{423}$ A Düsseldorfi Képzőművészeti Akadémiára való beiratkozásának legfontosabb motivációja volt, hogy Knaus közelébe jusson. Mindezt Ligeti Antal ajánlólevelének köszönhette, aki barátságban állt Knaussal. Jóllehet Knaus nem tudta tanítványául fogadni, de jó tanácsokkal látta el a fiatal művésznövendéket. ${ }^{424}$ Munkácsy

Pinothekaban nevezetesen egy Terniet meg Vandaikot vajon be fogadnak e este kiallitason mint maradhatok"

${ }^{421}$ OSZK.-Kézirattár, Levelestár, Munkácsy Mihály levele Ligeti Antalnak. 9. sz. levél, 1866. november 20.: „[...]épen ma jártam meg az uj Pinochtekát és a Mütarlatot, hol legjobban feltünt egy este felét ábrázoló tájkép „, Liell - töl. Az elött a kép elött meg kellett hajolni, annál nagyobb szerü tájképet még nem láttam. - Schleich - töl is van most kiállítva“

${ }^{422}$ OSZK.-Kézirattár. Levelestár, Munkácsy Mihály levele Ligeti Antalnak. 15. sz. levél, [1867] évszám

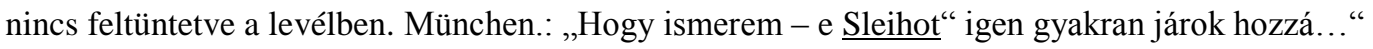

${ }^{423}$ Malonyai (1898), 101.o., Budapest, 1882. március 9. :,Kitűnö emberek nem állhatnak egymás mellett anélkül, hogy kezet ne fogjanak egymással.“ Ezt írta megboldogult férjem a „Gondolataiban“. A sors megtagadta töle azt az örömet, hogy Önnel, kiért már évekkel ezelött lelkesedett, kezet szoríthasson azon percen, midön az egész haza dicsöíti az Ön nagy müvét.“

${ }^{424}$ Malonyai (1898), 101-102.o. 
gyakran felkereste a mestert mütermében és a városban is többször találkozott vele. ${ }^{425}$ Knaus ugyancsak megkedvelte Munkácsyt, akit otthonában is meglátogatott, hogy készülő képei vázlatairól véleményt mondjon. Kompozícióiról elismerően nyilatkozott, ami pozítívan hatott a fiatal müvészre. ${ }^{426}$ Ez nagyon jelentős momentum volt Munkácsy életében, hiszen a müncheni magyar fiatal müvésznövendékek köre ellenszenvvel viseltetett Munkácsy irányában. Maga Szinyei Merse Pál is negatívan ítélte meg öt. ${ }^{427}$ Munkácsy persze érezte az ún. Piloty iskola magyarjaiból áradó ellenszenvet, amit Ligeti Antalnak is elpanaszolt egyik levelében. ${ }^{428}$

1867-ben Munkácsy Mihály ellátogatott a párizsi világkiállításra, ami nagy hatással volt rá a Piloty iskola magyarjainak negatív véleményének ellenére. ${ }^{429}$ (Ligeti Antalhoz

${ }^{425}$ OSZK.-Kézirattár, Levelestár, Munkácsy Mihály levele Ligeti Antalnak. 24. sz. levél, 1868, Düsseldorf: , ,... [ A Mehlkastenban Knausszal is gyakrabban találkozom. De nem csak ott, hanem nála is. T. i. Ateliereben mert én bizony meg-meg látogatom.“

${ }^{426}$ OSZK.-Kézirattár, Levelestár, Munkácsy Mihály levele Ligeti Antalnak. 24. sz. levél, 1868,: ,[[...]Én rettenetesen drukkoltam miszerint[?] ha eljön hozzám s meg látja dolgaimat rettenetes Katzenjammereket fog csinálni [...] megelégedését fejezte ki kezdet képpen [...] Mutattam neki az árvíz és az újoncozás cimü vázlatomat is.[...]A kompozicio iránti tetszését nyilvánitotta. No csak hogy hát ezen is túl vagyok, most már nem is félek töle annyira. Különben, igazán nagyon jó és derék ember.“

${ }^{427}$ Pernetczky Géza (1970), Munkácsy. 8.o.:"Jól ismertem Munkácsyt, Münchenben 1866-1868-ban gyakran találkoztunk, eljött ö Leibl körébe, de mindenki lesajnálta. Nemcsak azért mert németül cask gagyogott, s kifejezésein halálra kacagták magukat a fiúk, de sajnálták, hogy nem haladhat. [...] A mesterségbeli tudásában nem hittünk...”

Lázár Béla (1944), Munkácsy Mihály: 1844-1944, emlékek és emlékezések a művész születésének századik évfordulójára.179.o.

${ }^{428}$ OSZK.-Kézirattár, Levelestár, Munkácsy Mihály levele Ligeti Antalnak. 12. sz. levél, 1867. április 8.: „[...] A Piloti iskola magyarjai pedig méltóságon aluli dolognak tartanak engem társaságokba hívni, hogy abban részt vehessek, a hoz egy kissé tolakodónak kellene lennem, ezt a szerepet pedig nem válalnám magamra, igy tehát, nincs egyéb ...[?] mint ezen veszteségböl amennyire lehet hasznot csinálni, ami ugy lehetséges, hogy azt az idöt amit különben társaságaikban a sorhazak ban toltenek, szep csendesen valami massal töltöm, Különben nem érdemel több szót.“

${ }^{429}$ Pernetczky (1970), 8.o.:" [...] Egy nap eltünt közülünk, s mikor újra elénk került, nagyban újságolta, hogy Párizsban járt. Általános vélemény volt, hogy kár volt az útiköltségért. Mindenki - kivétel nélkülúgy itélte meg, hogy nem foghat rajta Párizs. Mert hiszen ami munkát tőle láttunk, mind gyenge, 
címzett leveléből az is kiderül, hogy október 15-én érkezett Párizsba.) ${ }^{430}$ Ezen óriási kiállítás keretében a nagy kortárs európai festőmüvészek munkáit is egy csokorban láthatta. Gustave Courbet a saját pavilonjában több mint 120 alkotását állíotta $\mathrm{ki}^{431} \mathrm{a}$ realista irányzat szellemében. Nem hagyható figyelem nélkül az a tény, hogy Courbet jó kapcsolatban állt azokkal a német festőkkel is, akikkel Munkácsy baráti viszonyt ápolt. Roger Bonniot közlése szerint Ludwig Knaus, Ferdinand Heilbuth, ${ }^{432}$ Georg Saal, ${ }^{433}$ Paul Meyerheim ${ }^{434}$ és Adolf Menzel ${ }^{435}$ is Courbet baráti köréhez tartozott.

Düsseldorfban a „Café“ nevü kávéházban volt a találkozóhelyük ${ }^{436}$, ahol leginkább Courbet müvészete került beszélgetéseik fókuszába. Knaus Courbethez füződő barátsága sokat segíthet megérteni Munkácsy Mihálynak a realista irányzathoz való vonzalmának elmélyülését, illetve müvészetének ez irányba való nagyléptékü fejlődését, amit a Munkácsy irodalomban nem Knauson keresztül vezettek le a kutatók. Csupán az egyszeri párizsi kirándulás hatásának tulajdonították.

rajzhibákkal teli volt. Mikor aztán a Siralomház-zal nagy sikert aratott, és annak reprodukciója szemünk elé került, hogy egy szóval mondjam, senki se hitte, hogy ő festette.Talán Knaus vagy más festő korrigált belé. A mesterségbeli tudásában nem hittünk...”

Lázár (1944), 179.o.

${ }^{430}$ OSZK.-Kézirattár, Levelestár, Munkácsy Mihály levele Ligeti Antalnak. 14. sz. levél, 1867. október 14.: ,[...]én holnap az - az 15. - kén indulok Párizsba.“

${ }^{431}$ Bonniot Roger (1994), L’Influence de Gustave Courbet Sur La Peinture Allemande De La Seconde Moitié Du XIXe Siécle. 44.o.

${ }^{432}$ Ferdinand Heilbuth (1826-1889), német festő.

${ }^{433}$ Georg Eduard Otto Saal (1817-1870), német festő.

${ }^{434}$ Paul Friedrich Meyerheim (1842-1915), német festő és grafikus.

${ }^{435}$ Paul Meyerheim (1898-1905), német festő, illusztrátor.

${ }^{436}$ Bonniot Roger (1994), 33.,108.o. 


\subsection{Az áttörés: „Siralomház“6-1869}

Munkácsy müvészi érettségét az 1869-ben festett puritán témájú, leveleiben „Hajnalpír“ vagy gyakran „Suszter“-nek, ma „Ásító inas“- nak nevezett festménye igazolta, amely már a düsseldorfi művészkörökben is feltünést keltett. ${ }^{437}$ Ezen kisebb képe után festette meg a „Siralomház“ című képét, ami a párizsi szalon ${ }^{438}$ egyik aranyérmét nyerte el, ezzel megalapozva európai hírnevét. A francia kritikusok elismerően vélekedtek a képről. $^{439}$ A képről Ludwig Knaus is elismerően nyilatkozott, aki miután tudomást szerzett arról, hogy Munkácsy ezt a témát választotta, erről igyekezett lebeszélni. Ilges és Munkácsy személyes beszélgetése szerint a festő a következőképpen idézte fel Knaus szavait: „[...] önnek teljes mértékben igaza volt és én tévedtem, amikor a képről igyekeztem lebeszélni, most azonban nem tévedek, ha a képnek nagy sikert és alkotójának fényes jövőt jósolok.““440

Ludwig Knaus pedig a festmény hatásáról a következő gondolatokat vetette papírra:,Úgy emlékszem rá, mintha csak ma történt volna, emlékezett vissza Leisten professzor Düsseldorfban a Siralomház első kiállítására Leopold Tonzen műkereskedésében. Munkácsy festménye mellett Vautier műve volt látható - az

\footnotetext{
${ }^{437}$ OSZK.-Kézirattár. Levelestár. Munkácsy Mihály levele Ligeti Antalnak. 29. sz. levél, Düsseldorf, 1869. április 20.: “[...] A Suszterom (a Hajnalpír) jó müvészi renomét szerzett nekem de el adni a mint veszem észre a tárgy puritánsága miatt nehéz lesz.“

${ }^{438}$ Patricia Mainardi (1993), The End Of The Salon, The Salon of 1870.: Moral Order In The Fine Arts. 42-43.o.

${ }^{439}$ Le Temps, 1876. június. 4. Paul Manz: Munkacsy. In: Pernetzky (1970), Munkácsy. 46.o.: „Ez a festmény eseményt jelent Munkácsy úr pályafutásában. Igen szerencsés fordulatot, éspedig a fekete szín mellőzését, és egyben áttörést a halvány szürkére. [...] a kivitelezés csodálatos.“

${ }^{440}$ Ilges (1899), 44.o.: "[...] Sie haben ganz recht gehabt und ich war im Irrtum, als ich Ihnen von dem Bilde abriet, jetzt aber irre ich nicht, wenn ich dem Bilde großen Erfolg und seinem Schöpfer eine glänzende Zukunft prophezeie.“
} 
elismert művész képe szürkének és mattnak tűnt Munkácsy világító, teljes, életteli színtónusai mellett! Nagy és váratlan, általános közönségsiker volt, az emberek mindenképpen látni akarták a képet. Barátunkat, Miskát, ugyancsak készületlenül érte a siker. Fáradságos munkánkba került, hogy rábeszéljük, küldje el mestermüvét a párizsi salon kiállítására, nagyon félt attól, hogy visszautasítják.“

Maga Munkácsy is megemlékezett váratlan sikeréről Ligeti Antalnak írt levelében. Festményének sikerével kapcsolatosan megemlíti, hogy annak hatását csak fokozta a mellé kiállított Vautier festmény, amit a sajátjával együtt egy külön teremben állítottak ki. A képet olyan hatalmas érdeklődés kísérte, hogy például a kölni múzeum két ízben tett rá vételi ajánlatot. ${ }^{441}$ Hírneve kitüntetett képe következtében gyorsan terjedt, ami több megrendeléshez juttatta a festőt. Nem kis büszkeséggel írja Ligetinek, hogy olyan műkereskedővel, Gaupillal, szerződött, aki európai hínevü festőknek, például: Messioner, ${ }^{442}$ Knaus, Achenbachnak ${ }^{443}$ a mükereskedője. ${ }^{444}$ Szinyei Merse Pál és magyar barátai viszont meglepetésüknek és kételkedésüknek adtak hangot. Mint láttuk, megkérdőjelezték, hogy a kép egyedül Munkácsy ecsetjéből származik. ${ }^{445} \mathrm{~A}$ legnagyobb müvészeti folyóiratok közül például a „Die Zeitschrift für Bildende Kunst“ Andreas Achenbach, Ludwig Knaus és Vautier festményei mellett is a magyar festő

\footnotetext{
${ }^{441}$ OSZK.-Kézirattár. Levelestár. Munkácsy Mihály levele Ligeti Antalnak. 34. sz. levél, Düsseldorf, 1869. ,[...] Képem, valahára kész lett s a tüzpróbán már keresztül is ment. Amennyiben Wautiernak egy képével külön ki volt állítva, s annyira tetszett hogy bizony, bizony nem hittem volna, s csak azt sajnálom hogy már el van adva mert most sokkal jobban eladhattam volna. A kölni múzeum számára, honnan két izben is kaptam felhívást. Ma indítom képem utnak Párizs felé.“

${ }^{442}$ Ernest Messioner (1815-1891), francia festő és szobrász.

${ }^{443}$ Andreas Achenbach (1815-1910), német tájképfestő. Tesvére Oswald Achenbach (1827-1905), német tájképfestő.

${ }^{444}$ OSZK.-Kézirattár, Levelestár. Munkácsy Mihály levele Ligeti Antalnak. 32. sz. levél, Düsseldorf, 1869. : „[...] nem tudom hol veszem magam ezek kozt a nagy urak közt, hanem hát annak még is örvendek hogy látom miszerint az illetö nem olcsó, hanem jó képeket keres, amiért egy kissé csodálom is , hogy az enyémet megvette, no ha nem majd igyekszem neki oly jol csinálni, a mint tudom, mert most legalabb azon biztos tudattal dolgozom, hogy meg lesz fizetve.“

${ }^{445}$ Perneczky (1970), 8.o., Lázár (1944), 179.o.
} 
művét taglalta. A cikkből többek között azt is megtudhatjuk, hogy sokan szerették volna látni a festményt: „[...] nagy és megérdemelt feltünést keltett Munkácsy alakokkal teli festménye. Munkácsy tehetséges fiatal magyar, aki Münchenben tanult és körülbelül egy éve lakik itt. Ezen a képen a szülőhazájának egy szokását ábrázolja, miszerint a halákraítélt bünözőt a kivégzés előtt közszemlére teszik: ijesztően hatásos motívum, ami érdekes és jellegzetes részleteket kínál az odaáramló tömeg ábrázolására, amit a festő ügyesen használ ki. Az egyének ábrázolása tökéletesen sikerült, ahogy a rendkívül mély színezés, ami a müvész további fejlődésével kapcsolatban nagy reményekkel kecsegtet.“446 Eugen Obermayer, a „Die Zeitschrift für Bildende Kunst“ képzőművészeti folyóirat párizsi tudósítója a következőképpen számolt be Munkácsy Szalonban kiállított képéről: „[...] ez a kép, a mi Knausunk szabad és egyszerü stílusában - de nála mégis erőteljesebben, híressé tette itt az eddig ismeretlen magyart. A belső mozgás, ami Munkácsy összes alakját átjárja, valóban szellemdúsan kerül bemutatásra, és az aprólékos kivitelezést nem lehet eléggé dicsérni.“447 Obermayer kritikájának a tükrében érzékelhetővé válik, hogy Munkácsy Mihály elérte célját és Ludwig Knaus, a nagy példakép nyomdokába lépett. Idővel túl is szárnyalta mesterét. Munkácsy Mihály neve 1870-ben már a két korábbi nagy “M” mellett, Hans Makart ${ }^{448}$ és Jan Matejko ${ }^{449}$ neve mellett szerepelt a művészeti kritikában. ${ }^{450}$ B. Goldscheider műkritikus ugyanennek a folyóiratnak a hasábjain a következő cikket jelentette meg Munkácsy művészetéröl:

„[...] egészen a konvencionális szabályokkal ellentétes, miszerint a hírnév egy olyan gyümölcs, aki halandóknak nem esik az ölébe. [...] Ez a fajta siker elérése a zsenik

${ }^{446}$ Zeitschrift für Bildende Kunst. (1870), Kunst-Chronik.Beiblatt zur Zeitschrift für bildende Kunst.Kunstvereine, Sammlungen und Ausstellungen. B. Düsseldorf. Bd. 5., 94.o.

${ }^{447}$ Zeitschrift für bildende Kunst.(1870), Kunst-Chronik. Beiblatt zur Zeitschrift für bildende Kunst. Der „Salon“ von 1870. Bd. 5., 150.o.

${ }^{448}$ Hans Makart (1840-1884), osztrák festő és dekorművész.

${ }^{449}$ Jan Matejko (1838-1893), lengyel historizáló stílusú festő.

${ }^{450}$ Zeitschrift für Bildende Kunst.(1870), Kunst-Chronik.Beiblatt zur Zeitschrift für bildende Kunst. Zwei neue Bilder von Hans Makart. 5. kötet, 1870. 193. o.:“[...] neue auftauchende phänomenale Erscheinung." 
névjegyét viseli magán. A középszerüség sose fog ilyen sikereket ünnpelni, ez egész bizonyos.“451 A „Siralomház“452 sikere nemcsak környezetét, de magát Munkácsyt is meglepte. Felkészületlenül érte, ami lekileg nagyon megviselte. ${ }^{453,454}$ Ennek ellenére nem kis büszkeséggel nyugtázta Ligetinek írt levelében, hogy Goupil szerint Ludwig Knaus fellépése óta nem volt olyan kép kiállítva a Párizsi Szalonban ami olyan nagy feltünést keltett volna, mint a Siralomház. ${ }^{455}$

\footnotetext{
${ }^{451}$ Zeitschrift für bildende Kunst.(1870), Kunst-Chronik.Beiblatt zur Zeitschrift für bildende Kunst.Zwei neue Bilder von Hans Makart. Bd.5., 1870., 193. o.

${ }^{452}$ Genthon István (1935), Az új magyar festöművészet története. Budapest.

${ }^{453}$ OSZK.-Kézirattár, Levelestár. Munkácsy Mihály levele Ligeti Antalnak, 37. sz. levél, 1870. május 31. Párizs: „Oh! Én sokkal nehezebbnek tartom megtartani a mgállapított hír nevet mint megszerezni. Hisz ime a tapasztalás is azt mutatja. Én magam sem tudom, hogy jutottam minden nagyitás nélkül egyszerre oly állásra, amilyenröl csak néhány hó elött is. Még csak gondolni sem mertem volna. Ez be következzen egy szerencsés véletlen által,de már most e szerencsés véletlent az - az e véletlen szerencsét egy egész életre kiterjeszteni, bíz ahoz azt hiszem meg eröm legnagyobb megfeszítése szükséges.“

${ }^{454}$ OSZK.-Kézirattár, Levelestár. Munkácsy Mihály levele Ligeti Antalnak. 34. sz. levél, Düsseldorf, 1869.: “[...] S mióta képem ki volt állitva egész környezetem megváltozott, büszke professzorok a legnyájasabban üdvözölnek különben az efelét ösmeri Ligeti úr.“

${ }^{455}$ OSZK.-Kézirattár, Levelestár. Munkácsy Mihály levele Ligeti Antalnak. 36. sz. levél: „,[...] Goupil azt mondja, hogy Knaus elsö fellépés óta nem volt kép kiállítva a párizsi Salonban, mely oly általános elösmerésben részesült volna, mint a Siralomház s amiért is Gerome különös elismerését jelenti ki Goupil által, s minthogy tudja, hogy a napokban Párizsba megyek, meghívott magához. [...] Vajjon mit szól mindezekhez Székely Bertalan, a nagy----“
} 


\section{Munkácsy Mihály és a korabeli magyar festőelit az 1873-as bécsi világkiállításon}

A bécsi világkiállítás megszületésének alapjául egy 1866-ban született császári döntés szolgált, de végül az európai politikai események következtében csak később realizálódhatott. ${ }^{456}$ A császári döntés a világkiállítás teljhatalmú igazgatójává Dr. Wilhelm Schwarz-Senborn bárót nevezte ki 1870. Január 9-én ${ }^{457}$. Az 1870. május 24-én kelt újabb császári rendelet pedig az 1873-as évet jelölte meg a kiállítás évéül. ${ }^{458} \mathrm{~A}$ bécsi világkiállítás sajtója a nagy eseményt a béke, valamint a kultúrális fejlődés letéteményesének tekintett osztrák politika győzelmeként ünnepelte, ami a birodalom európai politikai súlyának hangsúlyozására is szolgált.

Az 1873-as év a bécsieket nemcsak a világkiállítás, hanem a császári ház fontos családi eseményei miatt is lázban tartotta, hiszen Ferenc József trónralépésének a huszonöt éves jubileuma is erre az évre esett. A császár ezen ünnepélyes alkalomból személyes védnöksége alá helyezte a kiállítást. ${ }^{459}$ A trónörökös, Rudolf főherceg nagykorúvá nyílvánítására szintén ugyanebben az évben került sor, valamint Gizella főhercegnő és Friedrich Wilchelm, Frigyes Vilmos porosz főherceg eljegyzése is a világkiállítás megnyitásakor vált nyilvánossá. A német-francia háborúskodás következtében a világkiállítási munkák előkészületei elhúzódtak. A Császári és Királyi Bécsi Világkiállítási Bizottság (Kaiserliche und Königliche Comission für die Wiener

\footnotetext{
${ }^{456}$ Weltausstellung 1873 in Wien.Offizielle Documente. 44. szám, Wien, 1873. 1.; Wiener Zeitung, 49. szám, 1866. február 28., 629.o.

${ }^{457}$ Weltausstellung 1873 in Wien. Offizielle Documente, 44. szám, 1873. Wien, 1.

${ }^{458}$ Weltausstellung 1873 in Wien. Offizielle Documente. Wien, 18.; Bömches, Friedrich (1874), Bericht über die Weltausstellung zu Wien. Wien, 1873. 1.

${ }^{459}$ Wiener Weltausstellungs-Zeitung, III. évfolyam, 101. szám, 1873. január 8., Franz Josef I. Kaiser von Oesterreich, König von Ungarn und Böhmen u. u.
} 
Weltausstellung) a munkáját viszonylag későn, 1871. augusztus elsején tudta megkezdeni. A kiállítás megrendezésének szabályzata 1871. szeptember 12-én nyert uralkodói jóváhagyást, majd szeptember 14-én került közzétételre.

A világkiállítás a császár személyes támogatása mellett Károly Lajos főherceg védnökségét is élvezte, a kiállítási bizottsag (Ausstellungs Comission) elnökéül Rainer föherceget, ${ }^{460}$ alelnökeinek Constantin zu Hohenlohe-Schillingsfürst herceget ${ }^{461}$ illetve az ausztriai miniszterelnököt, Adolf zu Auersperg herceget, ${ }^{462}$ a császári udvar és a külügyek miniszterét gróf Andrassy Gyulát és a londoni nagykövetet, Beust grófot nevezték meg. ${ }^{463}$ A kiállítás hivatalos orgánuma az előszőr 1871-ben napvilágot látott Wiener Weltausstellungs-Zeitung (Bécsi Világkiállítási Újság) lett. ${ }^{464}$

\footnotetext{
${ }^{460}$ Rainer-Ferdinand Maria Johann Evangelist Franz Ignaz von (1827-1913) Osztrák föherceg.Az osztrák hadsereg tábornoka. Az Osztrák Tudományos Akadémia kurátora.Az Osztrák Iparművészeti Múzeum védnöke.

${ }^{461}$ Constantin Fürst zu Hohenlohe - Schillingsfürst (1828-1896): Nagy érdemeket szerzett a bécsi körgyürü és a Prater munkálatainál.

${ }^{462}$ Fürst Adolf Carl Daniel von Auersperg (1821-1885) Cislajtania, azaz a Lajtán túli vidék miniszterelnöke.

${ }^{463}$ Friedrich Ferdinand Graf von Beust (1809-1886) Szász majd osztrák államférfi.

${ }^{464}$ A Bécsi Világkiállitás Lapja „A megjelenő lapoknak első hiteles forrásaként szolgállt, mely az olvasóknak a világkiállítási bizottság tevékenységéről adott hírt. Európa minden országában megjelent:"Wir organisirten Repräsentationen unseres Blattes in allen Ländern Europa's, in Afrika, Amerika, Asien und Australien. Als Missionär der großen Idee der Weltausstellung ging unser Blatt hinaus in alle Theile der bekannten Welt.,,Az idézett cikk írója a következően fogalmazott: „A bécsi világkiállítás irodalma velünk kezdődött. Az utánzás mindenféle fajtája felbukkant, de a kiállítás közönségének jóindulatát mindvégig a magunkénak tudhattuk." Wiener Weltausstellungs- Zeitung, III. évfolyam, 101. szám, 1873. január 8., Unsere 101. Nummer. A Borsszem Jankó 1873. április 27.-i számában, Kiállítási Újság és Szakközlöny a Magasabb Kiálhatatlanság Számára alcímmel a Világkiállítási Újság tükörképeként figurázza ezt ki, azaz legjellemzőbb rovatainak keresi meg a maga Borsszem Jankó stílusban megírt szarkasztikus párját. Világkiállításunk, Kiállitási Hirek, Kiváló Épíkezések, Magas Vendégeink, Kitüntetések, A világkiállítások föladata: Borsszem Jankó, 6. évf, 278.szám, 1873.április 27., Kiállítási Újság.
} 
Bécsnek nehéz szerep jutott a világkiállítások történetében, hiszen az 1867-es párizsi kiállítás újdonságai olyan arculatváltást jelentettek, amelyek pozitív hatásaként megnőtt az érdeklődés, másrészt az ennek felkeltését megcélzó óriási fényűzés, jelentős mértékben növelte ennek költségeit. ${ }^{465} \mathrm{Az}$ ezidáig egymással vetélkedő London és Párizs mellett 1873-ban Bécs is igyekezett méltó vetélytársként feltünni és újdonságaival nagyobb népszerüségre szert tenni.

A világkiállítások egymáshoz viszonyított térbeli terjedelme valamint az ezeken résztvevő kiállítók számaránya és a kiállítások látogatottsága híven tükrözi ezen bécsi törekvéseket. $^{466}$ A szervezők a hangsúlyt a specializálódásra és az extensivitásra fektették. A művészetek, az ipar és a tudományok mellett nemcsak a nevelésügy, hanem az őstermelés ágazatai, az állattenyésztés és a növénytermesztés is helyet kapott. ${ }^{467} \mathrm{~A}$ járulékos kiállítások (additionelle Ausstellung-ok) pedig az egyes termelési ágak múltjáról is igyekeztek hiteles képet nyújtani. Európában a nemzetközi kongresszusok szervezése további babérok megszerezését jelenthette a kiállítók számára.

A kiállítás megrendezésének helyéül több bécsi helyszín neve is felmerült, úgy mint a ún. Glacis, a Prater vagy a Simmeringer Haide. Végül a választás a Praterre, ennek is az ún. kiraui részére esett. ${ }^{468}$ Ennek a területnek a kijelölésében nagy szerepe volt annak, hogy a Prater kedvelt szórakozóhelye lévén a bécsi publikumnak az idők folyamán a közlekedés itt kiválóan kiépült és a város több pontjáról könnyen megközelíthető volt. $^{469,470}$ Egyedüli hátránya sajátos mikroklímája volt, amit a kiállítás épületeinek

\footnotetext{
${ }^{465}$ Gelléri Mór (1885), A kiállítások története, fejlődése és jövendőbeli rendszeresítése. Budapest, 40. o.

${ }^{466}$ Gelléri (1885), 48-49. o.

${ }^{467}$ Gelléri (1885), 42. o.

${ }^{468}$ Meyer (1873), Meyers Reisebücher Wien. Weltausstellung 1873. Führer durch die Kaiserstadt und auf den Besuchtesten Routen. Österreich - Ungarn. Unter besonderer Berücksichtigung der WeltAusstellung. Hildburgmausen Bibliographisches Institut. Wien, 1873. 551.o.

${ }^{469} \mathrm{Az}$ északi vasútvonal kiváló szállítási lehetőségekkel rendelkezett, hiszen a többi vasútvonallal összeköttetésben állt. A vasútvonalakon kívül a Prater fő útvonalan lóvasút közlekedett, ami az északi elővárosokkal teremtett kapcsolatot. E mellett a dunai gőzhajók és a bécsi összekötő vonatok megkönnyítették a látogatók számára a kiállításra való ellátogatást
} 
tervezésekor a tervezőknek nem lehetett figyelmen kívül hagyni. A bécsi világkiállítás összterületét figyelembe véve szembetűnő, hogy az ezidáig megrendezett kiállításoknál jóval nagyobb területen került megrendezésre. ${ }^{471}$ A bécsi világkiállítás összterülete ugyanis 28,6-szor illetve 12,5-ször nagyobb volt az első és a harmadik londoni világkiállításnál, valamint 22,6-szor illetve 5,3-szor nagyobb volt, mint a második és a negyedik parizsi kiállítás.

6. ábra Korábbi világkiállítások területi összehasonlítása

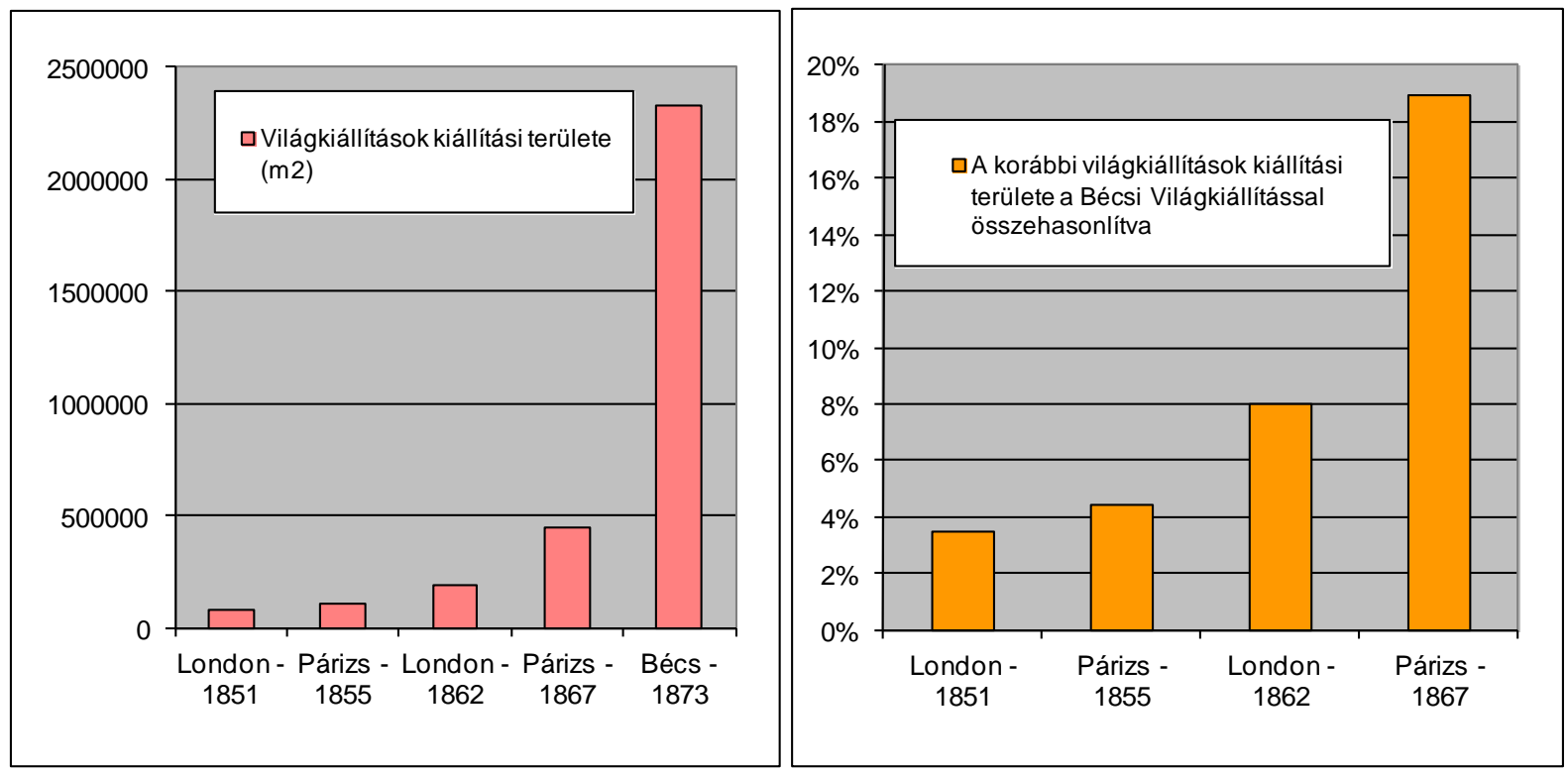

Forrás: Meyer, 1873, 551 o., Dr. Fr. Förster:Illustrierter Wiener Fremdführer. Wien, 1873, 59.o.

A megépített bécsi pavilonrendszer 950 méter hosszan és 205 méter szélességben helyezkedett el a Prater területén. Az úgynevezett föcsarnok (Hauptgalerie) 25 méter

\footnotetext{
${ }^{470}$ Meyer, (1873), 552.o.

${ }^{471}$ Förster Franz (1873), Illustrierter Wiener Fremdführer. Praktischer Wegweiser mit besonderer Berücksichtigung.Der Weltausstellung und aller Sehenswürdigkeiten und Grossem, ausführlichem Plane der Stadt, ferner Plänen.Wien, 1873. 59.; Meyer, (1873), 551.o.:

1851-London, Hydepark: 81591 m2, 1855-Paris, Champ-Elisées: 103156 m2.; 1862 London, Brompton: 186125 m2.; 1867- Paris, Champ de Mars: 441750 m2.
} 
széles volt, melyet további 16 úgynevezett keresztcsarnok (Quergalerie) kötött össze, melyek külön-külön 15 méter szélességben és 75 méter hosszan terültek el úgy, hogy a föcsarnok keresztülmetszette a keresztcsarnokokat. Mindezeket további két 35 méter széles udvar egészítette ki. Ennek a pavilonrendszernek a súlypontját egy körpalota, a „Rotunde“ képezte, a pavilonrendszer középpontjában helyezkedett el, azt két egyenlő részre osztva. Ezt a londoni világkiállítás (1851) üvegpalotájával világhírüvé vált építész, Scott Russel tervezte. Átmérője 79 méter volt és hatalmas méreteinek is köszönhetően a világkiállítás ékköveként, szimbólumaként tartották számon. Az épületben elhelyezkedő 8127 négyzetméteres kiállítóterem az ún. elitkiállításnak adott otthont. ${ }^{472}$ A Rotundához további mellékgalériák és kereszthajók tartoztak. A befedett területek összessége mintegy 180 ezer negyzetmétert tett ki. A nagyobb látogató tömegek minél egyszerübb befogadása végett a pavilonrendszert négy főbejáraton keresztül lehetett megközelíteni. ${ }^{473}$ A bécsi világkiállításon szemlére bocsátott tárgyakat 26 föcsoportra osztották. ${ }^{474}$ Ezen belül a kortárs mủvészetek a huszonötös csoportba kerültek.

\footnotetext{
${ }^{472}$ Wiener Weltausstellungs-Zeitung, III. évfolyam, 1.szám, 1873. január 8., John Scott Russell. Itt a világkiállítás megnyitásakor Ausztria, Franciaország, Németország, Olaszország, Belgium, Hollandia, Anglia, Oroszország és Svédország remekei kerültek kiválasztásra.

${ }^{473}$ Főbejárat, északi, nyugati és keleti bejárat.

${ }^{474} 1$. Bergbau und Hüttenwesen, Bányászat és Fémolvasztás; 2. Land- und Forstwirtschaft, Mezőgazdaság és Erdőgazdálkodás; 3. Chemische Industrie, Vegyipar; 4. Nahrungs- und Genussmittel als Produkte der Industrie Élelmiszer és Élvezeti iparcikkek; 5. Textil- und Bekleidungsindustrie, Textil és Ruhaipar; 6. Leder- und Kautschukindustrie, Bőr és Kaucsuk ipar; 7. Metallindustrie, Fémipar; 8. Holzindustrie, Faipar; 9. Stein-, Ton- und Glasindustrie Kö-, Agyag és Üvegipar; 10. Kurzwarenindustrie, Rövidárú/textil ipar; 11. Papierindustrie Papir ipar; 12. Graphische Künste und gewerbliches Zeichnen, Illusztrációs, vagy grafikus művészet, Műszakirajz; 13. Maschinenwesen und Transportmittel, gép- es jármügyártás; 14. Wissenschaftliche Instrumente Tudományos müszerek; 15. Musikalische Instrumente, Hangszerek; 16. Heerwesen, Hadügy; 17. Marinewesen, Tengerészet; 18. Bau- und CivilIngenieurwesen, Építész- és müszaki mérnökség. 19. das bürgerliche Wohnhaus mit seiner inneren Einrichtung und Ausschmückung A polgári lakóház belső és külső díszítése. 20. Das Bauerhaus mit seinen Geräthen und Einrichtungen, Parasztház szerszámokkal és berendezése.
}

21. Die nationale Hausindustrie, Nemzeti háziipar, 22. Darstellung der Wirksamkeit der KunstgewerbeMuseen Az iparművészeti múzeumok hatékonyságának bemutatása. 23. Egyházi művészet, Die kirchliche 


\subsection{A müvészeti kiállítás általános problémái}

A bécsi világkiállításon a rendezők nagy hangsúlyt fektettek arra, hogy a jelenkor müvészei, ahogy már 1855-ben a párizsi világkiállításon is történt, különálló teremben állíthassák ki müveiket: „Ez alkalommal rangjuknak megfelelően kerültek elhelyezésre megkülönböztetés nélkül. A művészet méltósága nem szenvedett csorbát, önáló mesterségként lett immár elkülönítve, egyben respektálva is." ${ }^{475}$ A művészeti pavilon a Rotunde-vel átellenben, a gépcsarnokkal párhuzamosan helyezkedett el. ${ }^{476} \mathrm{~A}$ pavilon kiállítótermének falai mintegy 6995 négyzetméter felületet tettek ki. ${ }^{477}$

A kiállítandó müremekek a Künstlerhof, vagyis a müvészudvar területén a Kunsthalleban voltak kiállítva. A mellette lévő pavilonbanvaz „Exposition des Amateurs“ kapott helyet. ${ }^{478} \mathrm{~A}$ müvészudvar területéről a mezőgazdasági pavilon irányába egy hídon keresztül lehetett továbbjutni. A német képzőművészeti folyóirat

Kunst. 24. Objekte der Kunst und Kunstgewerbe früherer Zeiten, ausgestellt von Kunstliebhabern und Sammlern, Korábbi korok művészete a műkedvelők és műgyűjtők kiállításában; 25. Die bildende Kunst der Gegenwart, A jelenkor müvészete; 26. Erziehungs-, Unterrichts- und Bildungswesen, Nevelés, Oktatás és Képzés.

${ }^{475}$ Meyer, (1873), 570.o.

${ }^{476}$ Wiener Weltausstellungs-Zeitung, III. évfolyam, 176. szám, 1873. június 15., Bilder vom Ausstellungsplatze XXXVIII. Die Kunsthalle.

${ }^{477}$ Meyer, (1873), 562.o.

${ }^{478}$ A (művészeti) szakosztály a következő tartalmú átiratot intézete a fiókbizottság elnökéhez:,,A világkiállítási országos bizottmány IV. szakosztálya elhatározta, hogy a hazánkbeli köz és magán gyüjtemények tulajdonosait illetőleg igazgatóit felhívja, gazdagítsa a kiállítás magyar osztályát a régibb kor müvészeti és műipari termékeinek beküldésével, hogy a magyarországi „exposition des amateurs“ minél kitünőbb legyen“ Világkiállítási Közlöny, 4. szám, A világkiállítási országos bizottmány szakosztályainak müködése. IV. (müvészeti) szakosztály, 1872. május 26. 
neves kritikusa és szerkesztője, Friedrich Pecht véleménye szerint a bécsi építész Karl von Hasenauer ${ }^{479}$, aki a bécsi múzeumok mesteri építésze volt, a Kunsthalle külső megtervezésekor a legkevésbé volt művészi. ${ }^{480}$ A művészeti pavilon belső kiképzésében viszont mesterit alkotott, amiben nagy szerepe volt az új megvilágítási technika alkalmazásának: a tetőről érkező napsugarak az oldalsó ablakoknak, valamint a tetőn elhelyezkedő üvegbetéteknek köszönhetően optimális fénybeáramlást biztosítottak. A bécsi építész a későbbiekben ugyanezt a technikát alkalmazza majd a bécsi Kunsthistorisches és Naturwissenschaftliches Múzeumban. ${ }^{481}$

\subsubsection{A Múvészeti Csarnok avagy a Kunsthalle felosztása}

A francia-német háborúskodás szelleme a békekötés ellenére is sokáig kísértett és a bécsi világkiállításon is hol gyengébben, hol erősebben, de éreztette hatását. Olyan ártatlannak tünő esemény alkalmával is felszínre került, mint például a Művészeti Pavilon felosztása. A Kiállítási Bizottság fáradozásai dacára az Offiziöses Berliner Blatt híradásának köszönhetően a világkiállítás békés atmoszférája veszélybe került. ${ }^{482}$ A felosztás azért is volt lényeges kérdés, mert a különböző nagyságú termek különbözőképpen voltak megvilágítva, ezzel nagymértékben befolyásolva a kiállított művek élvezhetőségét. A rendezők igyekeztek mindkét fél kívánalmainak eleget tenni, a felosztás körüli vita mégis olyan mértékben elmérgesedett, hogy a probléma végül a nemzetközi politika porondjára is felkerült. Andrássy Gyula gróf külügyminiszternek, valamint Károlyi grófnak, mint a Császári Kilállítási Bizottság alelnökének be kellett

\footnotetext{
${ }^{479}$ Karl von Hasenauer (1833-1894), Osztrák épíész. A bécsi világkiállítás főépítésze is volt.

${ }^{480}$ Zeitschrift für Bildende Kunst, 19. szám, 1873. február 21., Die Weltausstellung in Wien. Die Architektur. 305-306.o.

${ }^{481}$ Pemsel, Jutta (1989), Die Wiener Weltausstellung von 1873. Böhlau Verlag Wien, Köln, 38.o.

${ }^{482}$ Wiener Weltausstellungs- Zeitung, III. évfolyam, 1.szám, 1873. január 8., Zur Raumvertheilung in der Kunsthalle.
} 
avatkoznia és a Német Birodalom Bizottsága előtt tisztázni a kényes szituáció részleteit, mert a helyzet már már politikai eszkalációval fenyegetett. ${ }^{483}$

A tények végül saját magukért beszéltek. A négy legnagyobb terem közül hármon, amelyek felső, illetve oldalsó megvilágítással voltak ellátva, három ország osztozhatott: Ausztria, a Német Birodalom és Franciaország. A fennmaradó negyedik, egyben utolsó nagyobb termen a többi ország osztozott. A kényes szituációról a Wiener Weltausstellungs-Zeitung újságírója berlini hírforrásokra utalva ${ }^{484}$ a következő gondolatokat osztotta meg olvasóival:

„A Művészeti Csarnok termei nem északi és déli fekvésűek, mivel az épület tagolása nem tökéletes északnyugati és dél-keleti tájolású. A felülről megvilágított termeknél egyáltalán nem jön szóba ez a kényes fekvés, mert ezek ugyanannyi fényt kapnak, az oldalmegvilágítással rendelkező termek egyik fele észak-nyugati, míg a másik fele délkeleti fekvésű: az észak-nyugati fekvés mindenesetre előnyösebb, bár egy ilyen épületnél nem eshet minden terem egy és ugyanazon oldalra. “485

A Wiener Weltausstellungs-Zeitung áprilisi cikke már arról tanúskodik, hogy a Mủvészeti Csarnok körüli vita nyugvópontra jutott, így a termek felosztása már tényként és nem megoldandó kérdésként merült fel. A Müvészeti Csarnok központi kiállítótermét tizenhat nagyobb és tizenhat kisebb teremre szabdalták fel. ${ }^{486}$ Mindehhez további négy sarokpavilon, felső megvillágítással, illetve még négy előcsarnok tartozott. Franciaország és Németország, a közöttük uralkodó feszült politikai helyzetnek köszönhetően, a legjobb feltételek mellett készülhetett a kiállításra. A két ország összesen nyolc nagy termet mondhatott a magáénak, a legjobb felülről való

\footnotetext{
${ }^{483}$ Wiener Weltausstellungs-Zeitung., III. évfolyam 14. szám, 1873. január 21., Über die Raum-und Lichtverhältnisse in der Kunsthalle. Beilage zu Nummer 14.der Wiener Weltausstellungs-Zeitung.

${ }^{484}$ Wiener Weltausstellungs-Zeitung, III. évfolyam, 14. szám, 1873. január 21., Über die Raum-und Lichtverhältnisse in der Kunsthalle; Beilage zu Nummer 14. der Wiener Weltausstellungs-Zeitung.

${ }^{485}$ Wiener Weltausstellungs-Zeitung, III. évfolyam 14. szám, 1873. január 21., Über die Raum-und Lichtverhältnisse in der Kunsthalle. Beilage zu Nummer 14.der Wiener Weltausstellungs-Zeitung.

${ }^{486}$ Wiener Weltausstellungs-Zeitung, III. évfolyam 131. szám, 1873. április 20., Die Raumvertheilung in der Kunsthalle und in den Pavillons des amateurs. (Pavillon der Amateure).
} 
megvilágítással, valamint további nyolc oldaltermet a mücsarnok elülső frontján. A központi terem bal oldalán lévő falfelületet Franciaország, a csarnok jobbján lévőt pedig Németország müalkotásai foglalhatták el. Ezen kedvező feltételekkel szemben kissé paradox módon a világkiállításnak helyet adó Ausztria a kiállítótermek csekély számával rendelkezett. A negyedik felső megvilágítással rendelkező ún. nagy kiállítótermet, ami tulajdonképpen egy, a müvészeti pavilonhoz kapcsolodó sarokterem volt, Magyarország birtokolhatta. Így az osztrák és magyar termek a német és francia kiállítótermekkel átellenben helyezkedtek el. Franciaország, Németország és AusztriaMagyarország a Mủvészeti Csarnok termeinek a háromnegyedét birtokolta. A fennmaradó termeken nyolc nemzet és régió osztozott: Anglia, Hollandia, Belgium, Svájc, Spanyolország, Portugália, Észak-Amerika és Görögország. Az ún. Amatőrök Pavilonjában öt nemzet képviseltette magát: itáliai, dán, svéd, norvég és orosz művészek állították ki munkáikat, ${ }^{487}$ bár a magyar híradásokból megtudhatjuk, hogy a magyarok is képviseltették magukat ebben a kategóriában. ${ }^{488}$

A világkiállítás müvészeti részének látogatásához feltétlenül szükséges lett volna egy jól szerkesztett katalógus, de 1873. május 2-án, a megnyitó napján a kinyomtatatott 10000 példányból a kasszáknál nem volt fellelhető példány. A jegyárusítók a felmerülő kérdésekre természetesen nem mindig tudtak válaszolni. ${ }^{489}$ A látogatóknak a katalógust egészen június 8-ig nélkülözniük kellett, annak megjelenéséig kénytelenek voltak a különböző nemzeti kiadványokból tájékozódni. ${ }^{490}$ Ezek azonban sok esetben nem nyújtottak megfelelő információkat: a rossz számozás miatt például ha a látogató a belga, vagy a svájci katalogusokból próbált tájékozódni, csalódnia kellett. ${ }^{491,492}$ A

\footnotetext{
${ }^{487}$ Wiener Weltausstellungs-Zeitung, III. évfolyam, 101. szám, 1873. Január 8., Die Raumvertheilung in der Kunsthalle und in den Pavillons des amateurs.

${ }^{488}$ Világkiállítási Közlöny, 4. szám, A világkiállítási országos bizottmány szakosztályainak müködése. IV. (müvészeti) szakosztály, 1872. május 26.

${ }^{489}$ Wiener Weltausstellungs-Zeitung, III. évfolyam, 146. szám, 1873. május 8., Weltausstellungs Notizen; Oesterreich-Ungarn, Der officielle General-Kataloge der Ausstellung.

${ }^{490}$ Wiener Weltausstellungs-Zeitung, III. évfolyam, 146. szám, 1873. május 8., Weltausstellungs Notizen, Oesterreich-Ungarn, Der officielle General-Kataloge der Ausstellung.

${ }^{491}$ Wiener Weltausstellungs-Zeitung, III. évfolyam, 159. szám, 1873. május 24, Aus der Kunsthalle III.
} 
hivatalos müvészeti katalógus megjelenésével a problémákat csak részben sikerült a szervezőknek kiküszöbölniük. A Müvészeti Csarnok térképe például olyan rosszul szerkesztett volt, hogy a kiállítás látogatói nem tudtak belőle tájékozódni.

A katalógus hiányosságáról a Neues Wiener Tagblatt újságírója fogalmazott a legszúrósabban: „Ha az általános katalógus rendszerezését követnénk, azt is mondhatnánk, hogy a déli sarkkör nyugatról északra tolódott. Ha ez igaz, akkor az osztrák katalógus főszerkesztőjének egy másik bolygón kellett lennie, amelyen Anglia Kínától északra található, ott, ahová mások Japánt helyeznék.““993 A kiállított művészeti munkák rossz számozása pedig további kritikára adott alkalmat. A legnagyobb skandallumot a hivatalos katalógus kapcsán Németország, Spanyolország és Portugália teljes kihagyása jelentette. A későbbi javított, hivatalos világkiállítási katalógust, amely 1873. augusztus 10-én jelent meg, a könnyebb használhatóság kedvéért két részre osztották. Az első egy tájékoztató áttekintést ${ }^{494}$ adott, s a borítólapja a kiállítási útvonal kalauzaként szolgált. A második részben pedig a megtekinthető munkák immár helyes számozását találjuk. A már végleges, hivatalos verzió mellett továbbra is fellelhetők voltak azonban a. nem hivatalos katalógusok, melyek közül kiemelkedett Erst Lehmann művészeti katalógusa (Führer durch die Kunsthalle). ${ }^{495}$

\subsection{Magyarország első önálló világkiállítási szereplése}

A bécsi világkiállítás alkalmával a Közel- és Közép-Kelet mellet Magyarország elsőként vett részt önálló államként. A bécsi világkiállítás első ízben nyújtott alkalmat

\footnotetext{
${ }^{492}$ Neues Wiener Tagblatt, 157.szám, 1873. június 1., Vom Lesetisch. Neue Ausstellungskataloge. 4.o.

${ }^{493}$ Neues Wiener Tagblatt, 157. szám, 1873. június 1., Vom Lesetisch. Neue Ausstellungskataloge. 4.o.

${ }^{494}$ Neues Wiener Tagblatt, 157.szám, 1873. június 1., Vom Lesetisch. Neue Ausstellungskataloge 4.o.

${ }^{495}$ Lehmann, Ernst (1873), Führer durch die Kunsthalle der Weltausstellung in Wien. Alfred HölderBeck`sche Universität-Buchhandlung, Wien. 1873.
} 
arra, hogy a magyar kiállítók, ezen belül is a müvészek, önállóan immár hazájukat képviselve állíthassák ki műveiket. ${ }^{496}$ A Städtische Pressburger Zeitungból illetve Báró Wenckheim Béla híradásából megtudhatjuk, hogy a magyar delegáció mintegy 4000 kiállítót számlált: az ország a mezőgazdasági terményeitől kezdve az ipari termékekig, a gyáripartól kezdve a képzőmüvészeti mủvekig igen széles palettán képviseltette magát. ${ }^{497,498}$ A kiállítók száma valamint kiállított termékeiknek a különböző szekciókban való szerepeltetése egyben a sajátos nemzeti karakter letéteményese is volt. Mindez hatalmas előrelépésként értékelhető, hiszen az 1867-es párizsi világkiállításon ugyancsak lett volna lehetőség ezen nemzeti jelleg kidomborítására, akár a müipari termékeket kiállító osztályt, akár csak az akkori nemzetközi zeneünnepélyt tekintve. Minderről Vajda Viktor a következőképpen emlékezett meg: „,...] a befolyásos körök csekélyelve a magyar dalárdaélet vagy fel nem fogva a dalárdaügy s általában a mü ez irányu jelentőségét, óvakodtak itt utasitást adni, mintha magyar emberben nem volna képesség müvészet terén is érvényesülhetni vagy legalább megállhatni a többi nemzetek mellett." ${ }^{499}$ A bécsi világkiállítás közönsége így elsőként láthatta egy csokorban az akkori magyar festőelit ${ }^{500}$ alkotásait.

Magyarország galériájának bejárata felett saját nemzeti címerét helyeztette el, termében saját nemzeti zászlaját és nemzeti címerét tủzette ki. A terem mérete az ország termelésének nagyságával és jelentőségével állt arányban, fogalmazott a Világkiállítási Újság. ${ }^{501}$ A magyar nemzeti karakter érvényesült a nemzet finanszírozta és építette

\footnotetext{
${ }^{496}$ Städtische Pressburger Zeitung, 157. szám, 1873. július 10., Die ungarische WeltausstellungsCommission.

${ }^{497}$ Städtische Pressburger Zeitung, 157.szám, 1873. július 10., Die ungarische WeltausstellungsCommission.

${ }^{498}$ HHStA Kabinettskanzlei-Vortrag, 1873:4479. Báró Wenckenheim Béla király személye körüli miniszter előterjesztése az uralkodónak, Bécs, 1873. december 6.o.

${ }^{499}$ Vajda Viktor (1870), Mủvészet és politika. Képek a magyar társadalomból. Pest, 136.o.

${ }^{500}$ „The Vienna Universal Exibition 1873: the art of Mihály Munkácsy in light of the German Criticism”, in: Conference proceedings, International conference of doctoral candidates, Ostrava, 2011. május 25.

${ }^{501}$ Wiener Weltausstellungs-Zeitung, III. évfolyam, 137. szám, 1873. április 27., Beilage: Ungarn in der Weltausstellung.
} 
magyar pavilonban, amelynek építészeti terve Julius Koch munkáját dícsérte. A Pressburger Zeitung újságírója úgy értékelte, hogy a magyar részleg nemzeti karaktere teljes egészében fel- illetve megismerhető volt. Emellet több kisebb, a nemzeti karaktert szépen szimbolizáló épület ${ }^{502,503}$ kelt életre a kiállításon, amelyek a látogató közönség soraiban nagy tetszésre leltek. ${ }^{504,505}$ „Olyan magyar tárgyak kerültek kiállításra, amelyekben megnyilvánult az iparágak kozmopolita karaktere, miközben külső díszítésük a nemzeti karakter hordozójává vált, olyannyira, hogy a bécsi lapok mindezt nevetséges túlzásnak minősítették."506,507 A bécsi világkiállítás magyar országos

\footnotetext{
${ }^{502}$ Biographische Lexicon der Wiener Weltausstellung 1873. (1873), első kötet, 21. o. „A nemzeti karaktert volt hivatott szinbolizálni a Magyar Csárda életre hívott épülete is, amely a látogató közönség soraiban nagy tetszésre lelt. Ennek ellenére a Borsszem Jankó 1873. áprilisi számában, Kiállítási Újság című rovatán belül jelent meg Kiváló építkezések címmel egy szarkasztikus, fanyalgó stílusban megírt cikk, amely a következőképpen emlékezik meg a világkiállitási csárdáról: „E nagyszerü épület igen előnyösen hat, azon ethnografiai hűsége által melylyel az igazi magyar csárdáktól tökéletesen elüt. Aki ezt látja, az rögtön fogja tudni, hogy minő nincs a magyar csárda, s ebből következtetheti, hogy minőnek kell tehát lennie.“

${ }^{503}$ Borsszem Jankó 6. évf, 284. sz., 1873. június 8.: A Közkiállításon; Vindobona és a Nagy Világ majd A közkiállításon címmel a következőképpen ítélkezik:“Egy atyánkfia (az ugynevezett Magyar Csárda előtt). De azért délibábot mégsem tudott die bigyeszteni a nímet!“

${ }^{504}$ Wiener Weltausstellungs-Zeitung, III. évfolyam, 145. szám, 1873. május 7., Bilder vom Ausstellungsplatze, Pavillon der ungarischen Staatsvorst-Verwaltung; Wiener Weltausstellungs-Zeitung, III. évfolyam. 223. szám, 1873. augusztus. 9., Bilder der Ausstellungsplätze. Die ungarische Csárda, (Das ungarische Weinhaus).

${ }^{505}$ Wiener Weltausstellungs-Zeitung, 3. évf, 137. sz, 1873. április 27., Beilage: Ungarn in der Weltausstellung.:"Magyarország galériájának bejárata felett saját nemzeti címerét helyeztette el, termében saját nemzeti zászlaját és nemzeti címerét tüzette ki. A terem mérete az ország termelésének nagyságával és jelentőségével állt arányban.“

${ }^{506}$ Städtische Pressburger Zeitung, 157. szám, 1873. július 10., Die ungarische WeltausstellungsCommission.

${ }^{507}$ Borsszem Jankó, 1872. 5.évf, 243.szám, 1872. augusztus 25., A bécsi világkiállításra küldendő nemzeti tárgyak.
} 
bizottsága Korizmics Lászlolo ${ }^{508}$ vezetése alatt 1873. január 13.-án tartotta első ülését. ${ }^{509}$ Az ülésen olyan fontos kérdéseket tárgyaltak meg, mint a választmányi bizottság, 1873. évi költségvetése és a hivatalos katalógus nyelve. Az utóbbi kérdésben a választmány úgy döntött, hogy a kiadvány nem csak magyar, német és francia, hanem horvát nyelven is napvilágot lásson. Az elökészületi zsüri tagjai a már Pestre elküldött kiállításra szánt tárgyakat különböző kategóriákba sorolták. Ez alapján a negyedik, müvészeti szekcióba a régebbi és modern müvészet ${ }^{510}$ alkotásai kerültek. A magyar Világkiállítási Közlöny 1872. április 25-i számából megtudhatjuk, hogy 1871. december 19-én Barabás Miklós ideiglenes elnöklete alatt titkos szavazással a szekció elnökévé Ráth Györgyöt választották meg. Jegyzője Greguss Ágost lett, a végrehajtó bizottság tagjaiul Keleti Gusztávot, Pulszky Ferencet választották. Hetente üléseztek a Képzőmüvészeti Társulat helységeiben. ${ }^{511}$ Ezen szekció zsűritagjainak névsorában olyan személyekkel

\footnotetext{
${ }^{508}$ Aggszentpéteri Korizmics László (1816-1886)) mezőgazdász, agrárpolitikus, az MTA tiszteletbeli tagja.
}
${ }^{509}$ Wiener Weltausstellungs-Zeitung. III. évfolyam. 1.szám, 1873. január 8. Ungarn. Pest (Das Executiv Comité der ungarischen Landes-Commission für die Wiener Weltausstellung)

${ }^{510}$ Wiener Weltausstellungs-Zeitung. III. évfolyam. 1. szám, 1873. január 8., Ungarn. Pest: Das Executiv Comitéder ungarischen Landes-Commissionfür die Wiener Weltausstellung, A bécsi világkiállítás magyarországi komissiójának végrehajtó bizottsága: 5. Zsűri: Hunfalvy János, Léderer Ábrahám, Zichy Antal für die Seitensder Volksschulen auszustellenden Objecte.; 2. zsüri: Lewin Jakab, Ney Ferenc für die Mittelschulenauszustellenden Objecte; 3. zsüri: Hirschler Ignác, Sztoczek József, für die wissentschaftlichen Instrumente, tudományos müszerek; 4. zsüri: Hunfalvy János, Maday Isidor, Szalay István, für die Haus- und Nationalindustrie, házi és nemzeti gyáripar: 5. zsűri: Hausmann Alois, Keleti Gusztáv, grafika, für Zeichnungen u. Seitens der 4. Fachsecton: Alexy Károly, Perlaky Koloman, PulszkyFerenc, Rath György, Schickendanz, Simonyi Antal, Telepy Károly (modern művészetek) in der bildendenKunstder Gegenwart. zsüriében. Barabás Miklós, Keleti György, Kratzmann August, Szigeti Antal, Székely Bertalan, Than Mór, Gróf Waldstein János, a második zsüriben (Korábbi korok festészete) in der 2. JuryMalerei früherer Zeit. Almássy Pál, Doboczky Ignác, Hampel, Ipolyi Arnold, Rómer Flóris, Forma Károly.

5. Bildende Kunst derGegenwart, jelenkor müvészete: Angerer Nándor, Doby Jenő, Finaly Henrik, Kanitz Félix, Lippert Frigyes, Gróf Wladstein János, Gróf Zichy Ferenc.

${ }^{511}$ Világkiállítási Közlöny, 2. szám, A világkiállítási országos bizottmány szakosztályainak működése. IV. (müvészeti) szakosztály, 1872. április 25. 
találkozhatunk, mint a Magyar Művészeti Egylet neves tagjai és pártolói: Ráth György, Telepy Károly, Pulszky Ferenc, valamint megtalálhatóak voltak a korabeli magyar festők legjobbjai is: Than Mór, Barabás Miklós, Székely Bertalan és az ismert művészeti kritikus, egyben festő Keleti Gusztáv. ${ }^{512}$ A magyar művészeknek, akik munkáikat a bécsi világkiállításon ki szerették volna állítani, már nagyon korán el kellett kezdeniük a kiállításra való előkészületi munkákat. A müvészeti szakosztály az 1871. december 19-én megtartott ülésén úgy határozott, hogy a külföldön élő magyar művészekhez felszólítást intéznek a magyar osztályban való kiállítási szándékuk tárgyában. Többek között tudatva a müvészekkel, hogy csak az 1862 óta elkészült műveikkel vehetnek ezen részt. További ösztönző erőként szerepelt a felhívásban, hogy a Képzőművészeti Társulat éves vásárlását kizárólag a kiállíásra küldött müvekből fogja fedezni, valamint engedményként szerepelt, hogy a kiállítás magyar szekciójában való képek szerepeltetése esetén, azok ugyanazokban a szállítási elönyökben fognak részesülni, mint a velük ugyanazon országban alkotó külföldi művésztársaik. ${ }^{513} \mathrm{~A}$ bizottság 1872. május 12-én nyilvánosságra hozta a külföldön élő magyar müvészekhez intézett egységes mintára megfogalmazott levelét. ${ }^{514}$

\footnotetext{
${ }^{512}$ Dr. Illéssy János, Pettkó Béla(1998), A Királyi Könyvek. 102. o.: Keleti (Komjátszegi) Gusztáv nemesi előnevének (Kelety) megváltoztatására 1901. január.1-jén kapott engedélyt.

${ }^{513}$ Világkiállítási Közlöny, 2. szám, A világkiállítási magyar országos bizottmány szakosztályainak müködése. IV. (művészeti) szakosztály, 1872. április 25.

${ }^{514}$ Világkiállítási Közlöny, 3. szám, A világkiállítási magyar országos bizottmány, IV. (művészeti) szakosztálya felhívást intézett nevezetesebb hazai mủvészeinkhez és a hazai művész közönséghez. 1872. május 12.

„Tisztelt müvész úr![...] a szakosztály pedig a maga részéről törekedni fog, hogy a müvészeti czélokra szánt országos alapokból elsősorban a bécsi közkiállításon megjelent művek vásároltassanak.“ Világkiállítási Közlöny, 2. szám, A világkiállítási magyar országos bizottmány szakosztályainak müködése. IV. (müvészeti) szakosztály, 1872. április 25.

${ }^{514}$ Világkiállítási Közlöny, 3. szám, 1872. május 12. A világkiállítási magyar országos bizottmány, IV. (müvészeti) szakosztálya felhívást intézett nevezetesebb hazai müvészeinkhez és a hazai müvész közönséghez: „Tisztelt müvész úr! [...] a szakosztály pedig a maga részéről törekedni fog, hogy a müvészeti czélokra szánt országos alapokból elsősorban a bécsi közkiállításon megjelent müvek vásároltassanak, minélfogva uraságodnak alapos kilátása lehet, hogy a mit nekünk beküld, az el is fog
} 
Munkácsy Mihály szándéka a magyar kiállítóteremben való részvételre a szervezők számára sokáig rejtve maradt egy elkallódott levélnek köszönhetően, így a magyar művész hallgatása sokféle találgatásra adott okot. Olyannyira, hogy a budapesti Nemzeti Kaszinóban, mely a hetvenes években magyar kulturális élet egyik jeles színhelye is volt, jónéhányan szót emeltek Munkácsy magatartásával kapcsolatban. Ezaz itt több ízben jelenlévő nagybátyját, Reök Istvánt nagyon kellemetlenül érintette: „Tegnap ugyanis a Casinoban képz. m. egylet Elnöke Ráth György és Than Mór interpeláltak, nemtudok e valamit arról, miért nem értesíted a bécsi kiállítás magyar bizottságát arról, ha valjon szándékozol e kiállítani te -is mint magyar 73 ban?“515 A Magyar Művészeti Egylet tagjai Munkácsy Mihály életében nagyon fontos, mondhatni döntő jelentőséggel bírtak pályakezdése idején. Reök István levele is utal erre:’[...] Azért kértelek, ha távol vagyis, mint e haza fia, melynek ha pályád még oly fényes volna-is, az elsö támogatást köszönheted-ne felejtkezzél meg e hazáról, e múltról.[...] Figyelmeztettelek egyebekre is, de arra különösen, hogy ha hazádat megtagadni nem akarod, ne felejtsd el azt, s ha nem, add koronkint hazafiúi érzésednek jelét. S íme te ily közmegbírálásra adsz okot, adott szavadat se váltván be oly egylettel szemben, mely elsö volt tehetséges méltánylásában és támogatásodban... Mondd, minö érzéssel jösz egyszer ismeröseid körébe haza, ha arcaikról, ha nem szavakban is, hogy t.i. hazádról megfelejtkeztél.“.516

Munkácsy Mihály nagybátyjának írt válaszlevelében gyorsan tisztázódott a Párizsban élő festő álláspontja: „[...] a 73 diki Bécsi kiállítás tárgyában feleltem én annak idejében a kérdéses levélre, söt még magam is indítványoztam, hogy a magyar művészek külön állítsanak ki, és ezt a pétervari Zichy-vel tárgyaltuk is. Ö aztán fel szólalt Pesten levélben a mint tudom. Nem tudom mi lehet az oka, hogy erröl Pesten semmit sem tudnak. Miután én nagyon is erősen készülök, csakis mint magyar

kelni. Ha pedig abban a helyzetben volna Ön, hogy külföldről kellene művét a bécsi kiállításba küldenie, szerencsések vagyunk Önt értesíteni, hogy onnan is bátran csak a magyar osztályhoz utasíthatja küldeményként, mert ez esetben is részesülni fog mindazokban a szállítási előnyökben melyben az Önnel egy helyben lakók.“

${ }^{515}$ Czeglédi Imre ed. (1976), Levelek Munkácsyhoz, Munkácsytól, 1872. február 25., Reök István levele Munkácsy Mihályhoz. 50.o.

${ }^{516}$ Czeglédi Imre ed. (1976), Reök István levele Munkácsy Mihályhoz., 1872. február. 25., 51.o. 
kiállítani. [...] Nem szünök bíz én meg egy percre sem magyar és magyar müvész lenni, és a mennyire módomban ál, mindenkor pártolom a magyar müvészet érdekeit ${ }^{\text {‘517 }} \mathrm{A}$ Világkiállítási Közlöny 1872. május 26-án pedig már arról tudósít, hogy a művészeti szekció május 9-én megtartott ülésén bemutatták azon müvészek névjegyzékét, akik jelezték a magyar szekcióban való résztvételi szándékukat. Ezen a listán már Munkácsy Mihály nevével is találkozhatunk. ${ }^{518}$ Majd Helszmann Imre február közepén kelt levele hálásan köszöni meg Munkácsynak a magyar szekcióban való szereplésének szándékát! ${ }^{519}$

Munkácsy valóban gőzerővel készült, amit a „Zeitschrift für bildende Kunst” Munkácsyról szóló februári híradása is szépen alátámaszt: „Három másik, hasonló ártatlan témájú majdnem befejezett kisebb képét a festő Párizsban szeretné befejezni, ahol egy nagyobb kép megfestésén gondolkozik, aminek tárgya a festő egyéniségének felelne meg. Ez egy olyan jelenetet fog ábrázolni, amely a holdfényben egy városon keresztül szállított elítélteket ábrázol. A már elkészült vázlatok tanubizonysága szerint a kép nagyon lebilincselő hatású lesz. “520

A bécsi világkiállításra való készüléséről a festő beszámolt Kiss Károlyhoz címzett levelében is: „[...] Most egy nagy képet kezdtem meg, a bécsi világkiállításra $\mathrm{s}$ szorgalmasan kell dolgoznom, ha el akarom készíteni. Címe Az éjjeli kalandorok. “521 Amikor Munkácsy erre az elhatározásra jutott, döntésével egy egész ország előtt tisztelgett, ami nem maradt viszonzatlan az ország részéről. A festőre a továbbiakban nemzeti hősként tekintettek. Több magyar, de külföldi akadémián tanult müvészünk

\footnotetext{
${ }^{517}$ Czeglédi ed. (1976), Munkácsy Mihály levele Reök Istvánhoz. 52-53.o.

${ }^{518}$ Világkiállítási Közlöny, 4. szám, A világkiállítási magyar országos bizottmány IV. (művészeti) szakosztálya. 1872.május 26.

${ }^{519}$ Közli: Végvári Lajos, Munkácsy Mihály élete és művei. Budapest, 1958., 47.o.: Henszlmann Imre levele Munkácsy Mihályhoz, 1873. február 13.

${ }^{520}$ Zeitschrift für bildende Kunst. Kunst-Chronik. Beiblatt zur Zeitschrift für bildende Kunst., VII. évfolyam,8. szám, 1872. február 26., Personalnachrichten. Michael Munkacsy, 1872. február 26.

${ }^{521}$ Farkas Zoltán (1952), Munkácsy Mihály válogatott levelei. Budapest, 55. sz. levél. Munkácsy Mihály levele Kiss Károlyhoz. Párizs, 1872. február 17.
} 
számára nem volt egyértelmű műveiknek a magyar kiállítóteremben való szerepeltetése. Tekintve a hazai mủvészeti intézmények hiányosságait és a külföldi akadémiákhoz való nagyfokú elmaradását, jogosan érezhették, hogy műveik a magyar teremben nem találnak majd kedvező visszhangra. Félretették tehát patriotizmusukat és külföldi akadémiájuk képviselőiként állították ki műveiket. Színyei Merse Pál, Karl von Piloty tanítványaként, mint a Müncheni Akadémia kiállítója sajnos a német éremtáblázatot gazdagította. ${ }^{522,523}$ A bécsi világkiállításon való résztvétel sok festő számára szakmai, pénzügyi és társadalmi elsimertséget is ígérhetett. Munkácsy Mihály müveinek a magyar pavilonban való szerepeltetése hazafias magatartásán túl azt is jelzi, hogy a festő az előbbiekben felsorolt lehetőségeket a világkiállítás idejére már magáénak tudhatta és lépésével olyan nagy elödök példájának adózott, mint Szamossy Elek, Than Mór, Lotz Károly, a bécsi liberális gondolkodású Karl Rahl és a müncheni magyar professzorok: Liesen-Mayer Sándor és Wagner Sándor.

\subsection{A magyar „festőelit” első közös fellépése}

A magyar művészeti szakosztály erőfeszítései a minél nívósabb magyar művészeti kiállítás megszervezésére nem maradt hatástalan. A Világkiállítási Közlöny 1872. május 9-én közzétette, hogy a mủvészeti szakosztály május 31-én megtartott ülésén ötvenegy művész résztvételére számíthatott, ami a hazai viszonyokat tekintve minden várakozást felülmúlt. ${ }^{524} \mathrm{Ha}$ egy pillantást vetünk a kiállító magyar festők névsorára ${ }^{525}$, akkor

\footnotetext{
${ }^{522}$ Szinyei Merse Pál 1873. február 16-án kelt leveléből azonban az is kiderül, hogy szerette volna képét a Magyar Pavilonban kiállíttatni. Szinyei Merse Anna (1989), A Majális Festője Közelről. Szinyei Merse Pál levelezése, önéletrajzai, visszaemlékezések, 224. sz. levél, Budapest, 182-183. o.

${ }^{523}$ Weltausstellung 1873.in Wien. (1873), Amtliches Verzeichniss der Austeller, Ehrenpreise.900-901., Szinyei Paul von, 452. o.

${ }^{524}$ Világkiállítási Közlöny. 5. szám, A világkiállítás magyar országos bizottsága, IV. (müvészeti) szakosztály, 1872. június 9 .
} 
láthatóvá válik, hogy a magyar nagyközönségnek egy pillanatra sem kellett szégyenkeznie a világkiállítás publikuma előtt, hiszen Munkácsy neve mellett olyan híres festők nevét pillanthatták meg, mint Liezen-Mayer vagy Wagner, a kedvelt cári udvari festő Zichy Mihály, a már említett Lotz Károly, Than Mór vagy Székely Bertalan.

\section{7. ábra A világkiállításon kiállított képek száma}

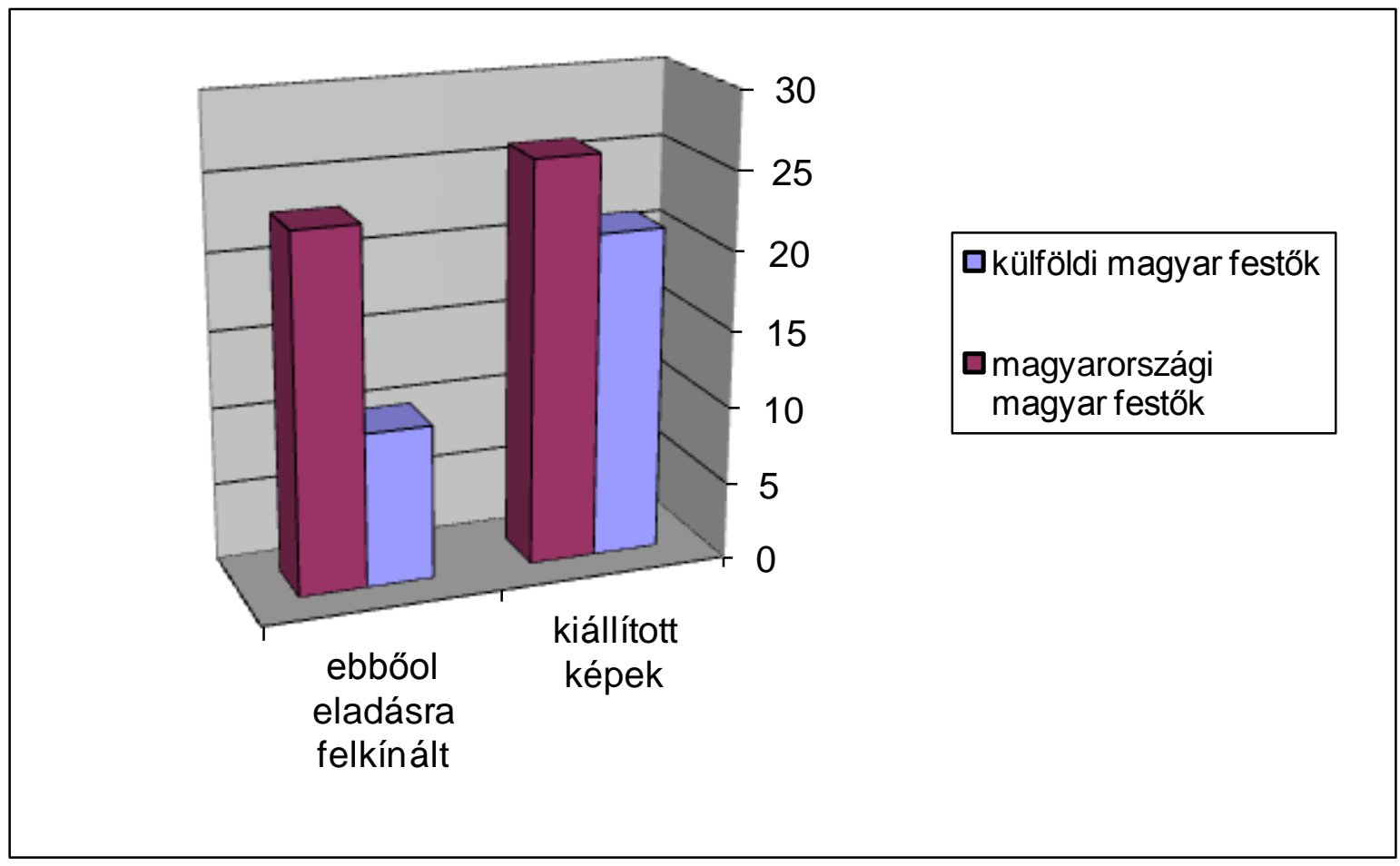

Forrás: Weltausstellung 1873 in Wien. Kunst-Catalog. 1. Kiadás. 68-70.o.

\footnotetext{
${ }^{525}$ Honismertető-Magyarország a bécsi 1873-diki közkiállításon. Különleges katalógus. A gazdaság, ipar, tudomány és művészet kiállított tárgyaiból. II. rész. A kiállítók és tárgyaik lajstroma. Budapest, 1873.; Weltausschtellung 1873 in Wien. Kunst-Catalog, 1 Auflage, 1873., 68-70.o.: Barabás Miklós, Baumgartner János, Brodszky Sándor, Bruck Lajos, Deutsch Ignác, Ebner Lajos, Gerhard A., Greguss János, Grim Rudolf vagy Rezső, Grosz Albert, Grosz Béla, Gschwindt Miklós, Guttmann János, Horovitz Lipót, Horovitz Ludwig, Ivanovics Katalin, Keleti Gusztáv, Kern Henrik, Kern Ármin, Kovács Mihály, Kratzmann Gusztáv, Liezen-Mayer Sándor, Ligeti Antal, Lotz Károly, Löschinger Zsigmond, Madarász Győző, Markó Ferenc, Markó Károly, Mészöly Géza, Molnár József, Munkácsy Mihály, Paál László, Pálik (Albert) Béla, Sajóssy Alajos, Schimmert S., Sikó Miklós, Székely Bertalan, Szoldatich Ferenc, Than Mór, Újházy Ferenc, Valentini János, Vastag György, Voitag György, Zahoray János, Zichy Mihály, Wagner Sándor, Weber Ferenc.
} 
A magyar kiállítóművészek munkáit mutató táblázatban (2. ábra) szembetünővé válik, hogy míg néhány festő csak nagyon kevés munkával szerepeltette magát, amelyek ráadásul nem voltak megvásárolhatók, addig más festők nagyszámú eladásra szánt munkával jeleskedtek. ${ }^{526}$

\footnotetext{
${ }^{526}$ Alexander Wagner: osztrák és magyar lista szerint: 1db.,Abschied der Königin. Izabella királynő búcsúja.
}

Alexander Liezen-Mayer: osztrák és magyar lista szerint:1db., Die Königinnen Maria und Elisabeth., Mária és Erszébet királynék Nagy Lajos sirjánál.

Markó Károly: osztrák és magyar lista szerint:1db., Der Berg Appeggi nächst Florenz, Az arppegi hegység Firenze mellett, eladó.

Markó Ferenc: osztrák és magyar lista szerint:4db., Theissgegend, Tiszai tájkép, eladó; Am Ufer der Theiss, A Tisza partján, eladó; Am Ufer der Theiss, eladó, Tenne, Szérü, eladó.

Munkácsy Mihály: osztrák és magyar lista szerint:4db., Nachtschwärmer, Éjjeli csavargók, Die Alte, Butter machend, Köpülő asszony, eladó; Männlicher Studienkopf, Férfi tanulmányfö, eladó; Wankende Heimkehr, Részeges férj hazatérése; Waldpartie im Herbst, Öszi erdőrészlet, eladó.

Zichy Mihály: osztrák lista szerint:10db: Lebensbild, aquarell, Életkép;, Porträtfigur, Arczképalak, szénrajz; Lebensbild, Életkép, szépiarajz, Sepiazeichnung; Der Todesengel,A halál angyala, ceruzarajz, Bleistiftzeichnung; Christus und die Priester, Krisztus és a papok, karton,eladó. Heinrich VIII., VIII. Henrik, Aquarell, a Wales-i herceg tulajdonában; Raphael Sanzio`s Atelier, Raphael Sanzio müterme, Sepiazeichnung, Kartenspieler, Kártyajátékosok, Aquarell; Faust, Fauszt, Kohlenzeichnung, eladó; Luther und der Papst, Luther és a pápa Carton, eladó. Az alvó nő, Aquarell; Manfred a halállal küzd, öklét fenyegetőleg a magasra emelve, eladó.

Bertalan Székely: Osztrák lista szerint: 9db. kép, magyar szerint:10db. kép: Die Waise, Az árva, eladó; Stelldichein, avagy Assonancez, eladó, Tököli im Schlosse Árva seinen Sohn zur Flucht drängend, Az Árva várában haldokló Thököli kardját átadva fiait menekülésre Inti, eladó; Die Japaneserin, Japán nő öltözködés közben, eladó; Leda, Léda és a hattyú szerelmes ölelésben, eladó, Die Witwe Az özvegy, eladó, Barmherzige Schwestern am Krankenbette, Irgalmas nénikék a gyermekágyas nyoszolájánál, eladó; Das wachsame Auge der Mutter, Az örködő anya, eladó; Ladislaus Posthumus unter Cilly's Bevormeldung. Utószülött László királlyal, gyámja Czilley Ulrik, mí az ifjú király előtte szökdelő tánczosnékon gyönyörködik, aláiratja Hunyady Lászlóhalálos ítéletét; Die vor dem Gewitter Flüchtenden. A zápor elöl menekülök. 
Azok a festők, akik nemzetközi szinten elismertségnek örvendtek, mint, Liesen-Mayer, Markó Károly, Zichy Mihály és Munkácsy Mihály, az első csoportba tartoztak. Ők elegendő képmegrendeléssel illetve eladással bírtak, nem kellett hajszolniuk a világkiállítás alkalmával az újabb megrendeléseket. Például Wagner és Liesen-Mayer Sándor a magyar szakosztályban csak egy- egy festmény állított ki. Markó Károly munkái Oroszországban ugyancsak nagy népszerüségnek örvendtek, ahogy a cári udvari festő Zichy Mihály művei is. Így nem meglepő, ha Markó megrendelői között olyan

Madarász Viktor(Győző), Osztrák lista szerint:2db.kép; Magyar lista szerint:4db. kép; Georg Dózsa, der Freiheitsmärtyrer, Dózsa György a szabadság vértanuja, eladó; Thierry’s Porträt, Thierry Amadé híres történetírónak, a magyar tud. Akadémia számára festett arczképe; Komárom megye föispánjának a megyei díszterem számára festett arczképe Porträt, Gabriel Bethlen unter seinen Gelehrten, Bethlen Gábor, a „pur si muove“ felett vitázó tudósok között verkäuflich. A magyar lista szerint nem eladó!

Than Mór: Osztrák és magyar lista szerint: 8db. kép, Nach der Marchfelder Schlacht, A Habsburg ház uralkodását megállapított „Marchfeldi“ csata után [1273], eladó, König Ladislaus der Kumane übergibt die Gefangenen an Kaiser Rudolph I. Kun László király átadja fogjait I. Rudolf császárnak, eladó; Porträt: Fr. Pulszky's Pulszky Ferenc arczképe Der Abendstern Az esti csillag, vagy napnyugta után [oder nach Sonnenuntergang], eladó, Christus am Kreuz, A keresztrefeszített - napfogyatkozásnál verkäuflich; Beatrix und Dante, Dante és Beatrix, eladó, Dante und Virgil in der Unterwelt, Dante és Virgil az alvilágban, eladó, Die Nacht, Az éj.(Az esti csillag mellékdarabja) eladó,, Kartons für den Fries, die er für das Stiegenhaus des ungarischen Nationalmuseums malte. A Magyar Nemzeti Múzeum lépszőházába festett Fries kartonjai Nr. 8-12 összesen 4 darab.

Lotz Károly: Osztrák és magyar lista szerint:1db. kép, Die Einkehr des Wegelagerers, Betyár beszállása a csárdába, miután lovát a küszöbhöz kötötte. eladó, Kartons für den Fries, die er für das Stiegenhaus des ungarischen Nationalmuseums malte, A Magyar Nemzeti Múzeum lépszőházába festett fries kartonjai, 17-ig, összesen 7 darab.

Barabás Miklós:Osztrák lista szerint: 2 db.kép, Weibliches Porträt, Női arczkép. Porträt., Portré.

Ligeti Antal: Osztrák lista alapján: 2db., magyar"alapján:3db., Aus den Umgegenden Jerusalems, Jeruzsálem szomszédságából, eladó Die Burg Vajda-Hunyad im restaurierten Zustande, Vajdahunyadi várkastély kijavított állapotában, eladó; Elhagyott táj a Libanonban, hiénak által körülcsatangolt nyitott sziklasírok, eladó.

Paál László: Osztrák és magyar lista szerint:1db. kép, Landschaft, Erdei tájkép borús estvilágításban, eladó. Weltausstellung 1873 in Wien.Kunst-Catalog. 1. Kiadás, Wien, 1873, 68-70.o.; HonismertetőMagyarország a bécsi 1873-diki közkiállításon. Különleges katalógus.A gazdaság, ipar, tudomány és művészet kiállított tárgyaiból. II. rész. A kiállítók és tárgyaik lajstroma.Budapest, 1873. 
ismert müvészetkedvelő nevével is találkozunk, mint a híres mügyüjtő Johann von Lichtenstein. ${ }^{527}$ A bécsi Ferdinand Waldmüller tanítvány Zichy Mihály a többi hírneves magyar festővel szemben több munkával képviseltette magát, bár ezen munkák nagy része nem eladó jelzéssel szerepelt, és ugyancsak szembetűnő, hogy közöttük kevés olajfesmény található. Akárcsak Zichy Mihály, Munkácsy Mihály első ízben tiszteleghetett müveivel hazája előtt ezen a nagy nemzetközi világkiállításon. Számukat számba véve látható, hogy alkotójuk e jeles alkalomnak ugyancsak nagy fontosságot tulajdonított. A festmények nagy része nem volt eladó, hiszen már a festő mütermében vevőre találtak, ${ }^{528}$ így őt a viszonylag nagy számú festmény kiállítására Zichy Mihályhoz hasonlóan patrióta érzelmei késztették.

A második csoportba azon magyar festők tartoztak, akik iskoláikat részben, illetve teljes egészében külföldön végezték, majd az ott szerzett tapasztalatokat Magyarországra hazatérve szerették volna kamatoztatni. Öket életszínvonalukat és financiális viszonyaikat tekintve nagy szakadék választotta el külföldön élő és nemzetközi szinten nagyobb elismertséget élvező társaiktól. Ezen különbségek nagyobb részben abból fakadtak, hogy a mükedvelő és müértő közönség rangosabb megrendelői az $\operatorname{arisztokrata}^{529}$ és a tehetős nagypolgárság ${ }^{530}$ soraiból kerültek ki, akik elsősorban olyan

\footnotetext{
${ }^{527}$ Lützow, Carl Friedrich Arnold von (1889), K. K. Akademie der bildenden Künste. Katalog der Gemäldegalerie. - Akademie der bildenden Künste. Wien, 392.o.

${ }^{528}$ A bécsi világkiállításra készült huszonötös csoport müveszeti katalogusának azon állítása, hogy Munkálcsy Mihály Éjjeli csavargók címü képe eladó lett volna a kiállítás alkalmával, sajnos nem helytálló. A művész levelezéséből kiderül, hogy már a mütermében 40000 forintért megvásárolta és a felét elöre a festőnek kifizette egy mükereskedő.

${ }^{529}$ Gróf Andrássy Gyula, Andrássy Aladárné, Batthyány Lajosné, Batthyány Gézáné, Károlyi Lászlóné, Teleki Sándorné, Pejacsevich Márkné. In: Csányi Károly ed. (1907), A budapesti amateur gyüjtemények kiállításának lajstroma. A kiállítók névsora. Horváth Hilda (1993), Adalékok a század eleji magyar mügyüjtés történetéhez. In: Müvészettörténeti Értesítő. Nr. 1-2., 27-39.o., Horváth Hilda (2000), Iparmüvészeti kincsek Magyarországon. 8. o.

${ }^{530}$ Cukorgyáros Hatvany-Deutsch család, Laczkó Fanny-Hatvany József felesége, Hatvany Károly, Hatvany-Deutsch Fanny. A dohánykereskedő és bankár Herzog Mór. In: Csányi Károly ed. (1907), A budapesti amateur gyüjtemények kiállításának lajstroma. A kiállitók névsora. Horváth Hilda (1993), Adalékok a század eleji magyar mügyüjtés történetéhez., Lengyel György (1986), Die ungarische
} 
festményekért voltak hajlandók nagyobb összeget áldozni, amelyek a korszak népszerü és divatosnak számító festőinek ecsetjei alól kerültek ki. A hazai környezetben a festészetből megélni vágyó művészek nagy része természetesen a hazai viszonyok miatt kiesett ebből a körből és művészi tevékenysége mellett más kiegészítő munka segítségével igyekezett jövedelmét kiegészíteni. Az úgynevezett kenyérkereső foglalkozások (Ligeti Antal esetében például a Nemzeti Múzeum teremőrsége) állandó keresetet és létbiztonságot biztosítottak családjaik számára. Jó például szolgál Barabás Miklós, aki fényképészeti mütermének megnyitásával igyekezett egzisztenciát teremteni. Ebből adódóan azonban ezek a művészek kevés időt tölthettek művészetük gyakorlásával, amit a világkiállításra szánt képek csekély száma is tükröz. Ligeti Antal például csupán két képpel képviseltette magát, amelyek vázlatai még a festő fiatalkori külföldi tanulmányútjának éveiből származtak. Barabás Miklós pedig két a továbbra is legbiztosabb kenyérkeresetnek számító portrét állított ki.

A bécsi Karl Rahl professzor egykori tanítványai, Than Mór és Lotz Károly, mint hazai környezetben megélni szándékozó festők, szintén a második csoporthoz sorolandók. A Magyar Nemzeti Múzeum megrendeléseire készült freskóik vázlatait állíttatták ki a világkiállítás alkalmával. Az állami megrendelés a két festő relatív hazai népszerüségére illetve a müvészeti körökben való elismertségre utal. Azonban e két tényező tekintetében a két festő között korántsem volt ilyen kiegyenlített a viszony. Than Mór leveleiből megtudhatjuk, hogy a festő pénzszükével küszködött, ezért a viszonylag sok, nyolc eladásra szánt képével igyekezett felhívni magára a figyelmet. Ellenben Lotz Károly a fent említett vázlatok mellett csupán egy képpel képviseltette magát. A világkiállításon Székely Bertalan volt az a magyar festő, aki a legnagyobb számban állíttatta ki festményeit, (a festő szénrajzait nem számítva) szám szerint kilencet, melyek kivétel nélkül eladóak voltak.

A második csoporthoz sorolandó Madarász Viktor festő is, aki dacára a külföldön elért sikereinek 1870-ben hazatért. Reményei ellenére nem sikerült beilleszkednie az akkoriban Keleti Gusztáv kritikái által erősen befolyásolt magyar művészmiliőbe.

Wirtschaftselite im 19. und zum Anfang des 20. Jahrhunderts: Lebensbahnen des Generationen. In: Bácskai Vera ed. Bürgertum und bürgerliche Entwicklung in Mittel- und Osteuropa. II. kötet, 591-694.o. 
Pályamüvei sorra elutasításra leltek, amit a müvészettörténészek egyrészt a festészeti stílusváltozással, másrészt a nagy rivális, ugyancsak történeti tárgyú képeket alkotó, ugyanakkor a kor hivatalos festőjének számító Benczúr Gyula szerepével magyaráznak. ${ }^{531}$ Az előbb említett okok mellett sokkal prózaibb az a tény, hogy a festőt forradalmi múltja hátráltatta az elismertség elérésében. A bécsi világkiállításon a magyar festők névlistájában Madarász Győző név alatt ugyanis Madarász Viktor műveivel találkozhatunk. ${ }^{532}$ A névváltoztatás sok találgatatásra adhat okot, hiszen a festő állandó kapcsolatokat ápolt a magyar emigrációval. Ugyanakkor a francia udvarban is kedvelték és Oroszországban is megfordult. Nem csoda, hogy szerteágazó kapcsolatai miatt a titkosrendőrség rendszeresen figyeltette. ${ }^{533}$

A a magyar és osztrák festők munkáinak témaválasztását összehasonlítva a következő megállapításokat tehetjük. A magyar festők kollégáikkal szemben még mindig az első és legelterjedtebbnek, illetve a legbiztosabb pénzforrásul szolgáló portréfestészetnek hódoltak, ami híven tükrözte a hazai müvészeti viszonyokat. A portrékat az életképek és tájképek követték, ami arra utal, hogy a müvészeti ízlés Magyarországon is lépést tartott a kor divatjával. Ezzel ellentétben az ausztriai festők legnagyobb számban tájképekkel, majd hajszállal lemaradva életképekkel képviseltették magukat a világkiállításon, a portréfestészet náluk már a harmadik helyre szorult vissza. A magyar szekcióban jelen lévő nagy számú történelmi témájú festmény tükrözte a téma magyar körökben való további népszerüségét, illetve a Eötvös József vallás és közoktatás miniszter által kezdeményezett történelmi témájú pályázatot. Az osztrák részben a historikus festmények alacsonyabb száma jelezte a müfaj popularitásának csökkenését és a korabeli népszerü genre elöretörését. Érdekes módon a csendéletek száma mindkét

\footnotetext{
${ }^{531}$ Tarján Tamás, $\quad$ Madarász $\quad$ Viktor halála. http://www.rubicon.hu/magyar/oldalak/1917_januar_10_madarasz_viktor_halala/

${ }^{532}$ Weltausstellung 1873 in Wien.Kunst-Catalog. 1. Auflage. 68-70. o.: Dózsa György a szabadságharc vértanúja, térdkép erőteljes határozott tartással, a háttérben égő város. Thierry portréja, Komárom megye főispánjának a megyei díszterem számára festett arczképe, Bethlen Gábor, a „,pur si muove“ felett vitázó tudósok között. Weltausstellung 1873 in Wien.Kunst-Catalog. 1. Auflage. 68-70.o.

${ }^{533}$ HHStA: BM. Akten. A 5478., Pest, 1865. szeptember 8.; Házi-, Udvari és Állami Levéltár, BM.Akták. A 5478., Pest.
} 
félnél szinte megegyezett. A már említett kategóriákon kívüli képek sokszínüsége inkább a magyar kiállító mủvészeket jellemezte, mủveik között szénrajzokat, aquarelleket és szépia rajzokat is találunk. 
8. sz. ábra. A magyar és osztrák festők kiállított festményeinek darabszáma és aránya az összes kiállított mühöz viszonyítva
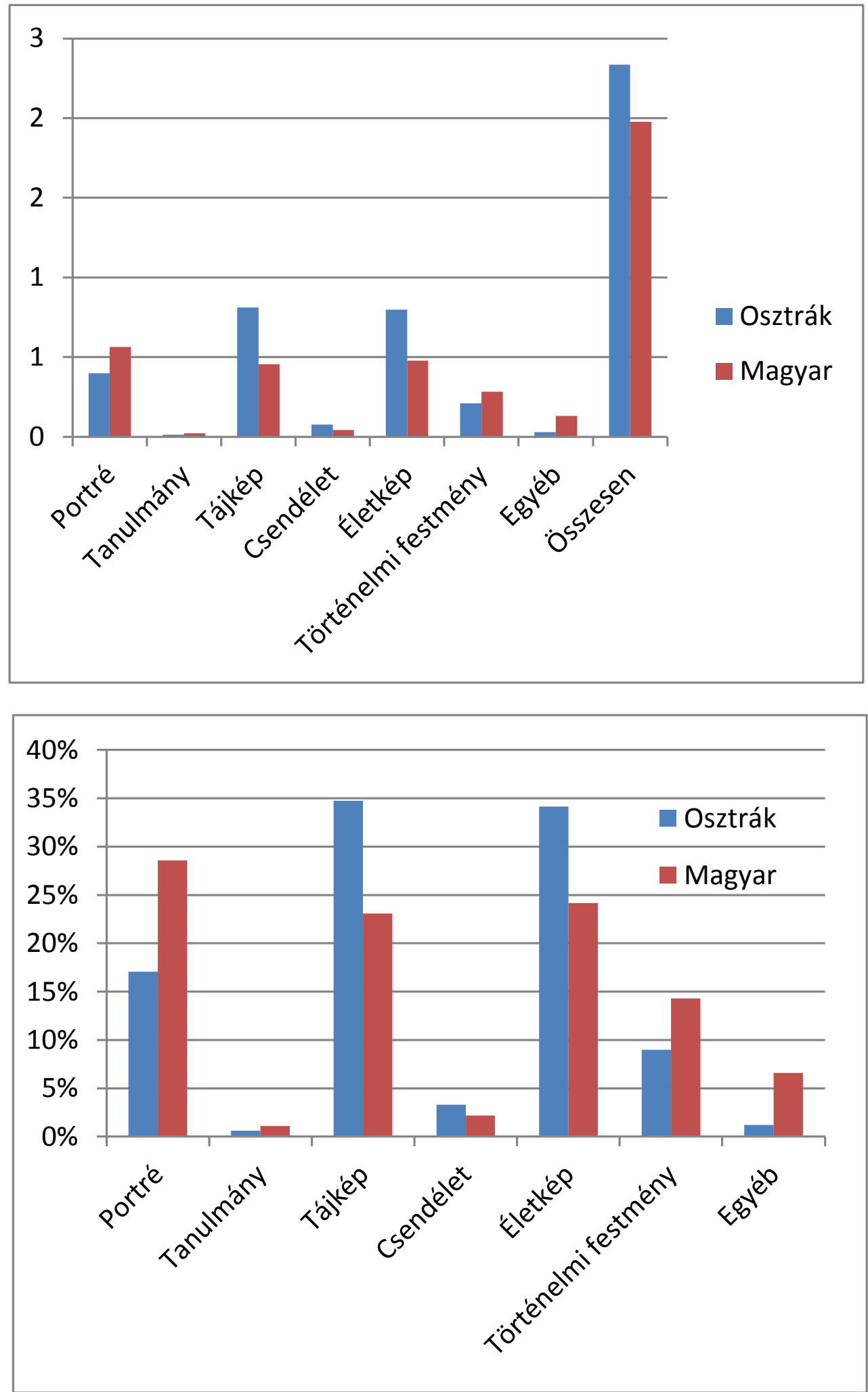

Forrás: Weltausstellung 1873 in Wien. Kunst-Catalog. 1. Auflage. 
A bécsi világkiállítás hivatalos orgánuma, a Wiener Weltausstellungs-Zeitung adatai szerint összesen 4702 műalkotást állítottak ki a müvészek, ${ }^{534}$ ami némileg kevésnek tűnik az „Offizielle Programme und Publicationen“ hivatalos listáját tekintve $(6600)^{535}$ A kiállított magyar mütárgyak számát összehasonlítva más nemzetek által kiállított müvek számával a magyaroknak több nemzetet sikerült megelőzniük. A fenti ábrán látható három százalék azt mutatja, hogy a hazai művészet relatív gyorsasággal kezdett felzárkózni a fejlettebbnek mondható európai nemzetekhez. A nagy történelmi intézményesült művészeti háttérrel rendelkező Béccsel szemben a művészeti intézményeket nélkülöző magyar müvészek munkái az 1873-as világkiállításon már a nyugat-európai szintü müvészeti fejlődéssel lépést tudtak tartani. 1870-ben Vajda Viktor alábbi idézetetéből reális képet kaphatunk az akkori magyar müvészeti akadémiát nélkülöző magyar állapotokról: „Ime, tanintézetek, taneszközök, mintaképek, műcsarnokok hiányában nálunk még most is kőfaragó a szobrász, mázoló a festész és a külföldre nem menekült s ujjal kimutatható nehány valódi müvészünk, közöny és közrészvétlenség miatt, alig talál foglalkozást.“536

Mindez annak a felnövekvő Magyarországon alkotó festőnemzedéknek is köszönhető, akik az ezt megelőző világkiállításokon (1862, London; 1867, Párizs) még díjnyertes műveket nem tudtak felmutatni, a bécsin viszont már érmekkel büszkélkedhettek.

\footnotetext{
${ }^{534}$ Die Vereinigten Staaten von Nordamerika:16, Brazilien: 1, Frankreich: 1527, Schweiz: 198, Italien: 625, Monaco: 3, Schweden: 45, Norwegen: 71, Dänemark: 101, Niederlande: 167, Belgien: 296, Österreich: 811, Ungarn: 155, Russland: 437, Griechenland: 37, Türkei: 1, China: 2, England: 203. Wiener Weltausstellungs- Zeitung, III. évfolyam, 171. szám, 1873.június 8., Aus der Kunsthalle VI.

${ }^{535}$ Weltausstellung 1873. in Wien, 76. szám, Offizielle Programme und Publicationen.

${ }^{536}$ Vajda (1870), 128-129.o.: „A magyar festészeti akadémia nem létében ép oly hiába keresnénk festésznövendéket ...E körülmény azonban egyrészt a tehetségek és hivatottak kifejlödhetését akadályozza, csak a kontárságot, felületeséget és izetlenséget mozditja elő, és azért bátran állithatjuk, hogy nálunk nem egyéb kontárnál az ugynevezett müvészek nagy tekintélyes része, mert legjobb esetben is csak ritka tanulónak nyilik alkalma itt Pesten valamiben kiképezhetni magát és jó utmutatás és vezetés hiányában a félszegség és modorosság vesz erőt a növendékeken, mielőtt az izlés csak valamennyire is higgadásnak indulhatott volna.“
} 
Müvészeti munkájuk 1873-ra teljesedett ki, vált éretté, részben a Mintarajziskola tanáraiként is példaként állhattak a fiatal magyar festőnemzedék elé. ${ }^{537}$ Ernst Lehmann, ismert bécsi művészeti kritikus a következőképpen foglalta össze személyes benyomásait a kiállító magyar művészekről: „A magyar részleg a szemlélődő látogató számára egy éppen önállóvá fejlődő művészet lebilincselő színjátékát mutatja،“538 Véleménye szerint a magyar müremekek meg tudják ragadni alátogatók figyelmét, mert ellentétben más (nemzetek) mütárgyaival, ezek sajátos karaktert, nevezetesen a magyar népi karaktert hordozták. Összegzésként megállapítja: „[...] mivel a magyarokat sohasem sikerült teljesen elnyomni, a magyar művészeti fejlődés egyetlen más európai nemzeti mủvészethez sem hasonlítható.“539 Friedrich Pecht neves német kritikus azonban a Lehmann által előnynek titulált sajátos magyar karaktert hátránynak értékelte és Munkácsy Mihály Öszi erdőrészlet címü képével kapcsolatosan ezen véleményének hangot is adott: „Ebből a festményből nagyfokú magyar barbarizmus sugárzik, ami inkább a hun birodalomra, mintsem a nemzet állítólagos lovagi múltjára emlékeztet: ebből az ábrázolásból Árpád fiait nehezen lehet megkedvelni. Ez a barbár vonás bizonyos mértékig a legöbb képen felfedezhető. “540

\footnotetext{
${ }^{537}$ Székely Bertalan 1871-töl az Országos Magyar Királyi Mintarajztanoda tanára, majd 1890-től igazgatója. Lotz Károly 1885-től az Országos Magyar Királyi Mintarajztanoda, majd a nők számára építtetett Festészeti Tanoda tanára. Kelety Gusztáv 1880-tól a Magyar Királyi Iparmüészeti Tanoda igazgatója. Greguss János az Országos Magyar Királyi Mintarajztanoda tanára.

${ }^{538}$ Lehmann (1873), 121.o.

${ }^{539}$ Lehmann (1873), 121.o.

${ }^{540}$ Friedrich Pecht (1873), Kunst und Kunstindustrie auf der Wiener Weltausstellung 1873. Verlag der J.

G. Tottalschen Buchhandlung. Stuttgart,183-184.o.: „Spricht also auch ein sehr großes Stück magyarischen Barbarenthums aus dieser Malerei, die weit mehr an das Hunien - als an das angebliche Ritterthum der Nation glauben macht, so dass man die Söhne Arpads aus dieser Schilderung schwerlich sehr hoch schätzen lernen wird, so findet man gerade von diesem barbarischen Wesen mehr oder weniger in den meisten andern Bildern.“
} 


\subsection{Díjak a kortárs képzőmüvészetek csoportjában}

A huszonötös csoport, azaz a kortárs müvészetek zsürije az elnök Grog Folliot de Crenneville-en és az alelnök Jean Louis Ernest Messioner-én, valamint herceg Ratiboron kívül 44 tagból állt. ${ }^{541,542}$ A nemzetek összetételének megfelelően a paletta meglehetősen színes volt: nyolc osztrák, hét francia, öt olasz, két magyar, két belga, két orosz, egy svájci, egy holland, egy spanyol, egy görög, egy svéd, egy dán és egy norvég zsüritag vett részt benne. A zsüri munkáját további tíz kiegészítő zsüritag segítette: öt francia, majd két magyar, két svájci és egy olasz. Amennyiben a tanácsadó vagy kiegészítő zsüritagokat is figyelembe vesszük, a magyar nemzetiségüek száma Franciaország, Ausztria és Olaszország után az előkelő negyedik helyet foglalta el. A magyar delegáltak között találjuk Pulszky Ferencet, a Nemzeti Múzeum igazgatóját, Ráth Györgyöt, a Magyar Királyi Legfelsőbb Bíróság bíráját, a bécsi műkereskedő Pozsonyi Sándort és a pesti építész Steinbach Imrét. ${ }^{543}$

A magyar müvészek elnyert érmeiket tekinte tekintélyes poziciót értek el a többi európai országgal való összehasonlításban. ${ }^{54}$ Tizennégy érmet nyertek el a festészeti kategóriában. Összesen, azaz más müvészeti ágakat is beleértve, a magyar kiállítók huszonhat érmet mondhattak a magukénak. Az érmek összes számát tekintve a magyar kiállítók a müvészet terén a nemzetek rangsorában a nyolcadik helyen végeztek. Magyarország ezzel az eredménnyel jóval Franciaország, Németország és Ausztria mögött, de Angliához és Oroszországhoz viszonylag közel teljesített.

\footnotetext{
${ }^{541}$ Weltausstellung 1873 in Wien. Liste der Mitglieder der internationalen Jury (1873), (Nach Gruppen alphabetisch geordnet), I.szám, 1873. június 20., Gruppe XXV. Bildende Kunst der Gegenwart, 57-59.o.

${ }^{542}$ Wiener Weltausstellungs-Zeitung, III. évfolyam, 187. szám, 1873. június 28., Weltausstellung-Die Mitglieder der internationalen Jury.

${ }^{543}$ Weltausstellung 1873 in Wien. Liste der Mitglieder der internationalen Jury (1873), Gruppe XXV. Bildende Kunst der Gegenwart, 58-59.o.

${ }^{544}$ Wiener Weltausstellungs-Zeitung, III. évfolyam, 196. szám, 1873. július 6., Die Arbeiten der Jury.
} 
9. ábra Az országonként elnyert kitüntetések száma

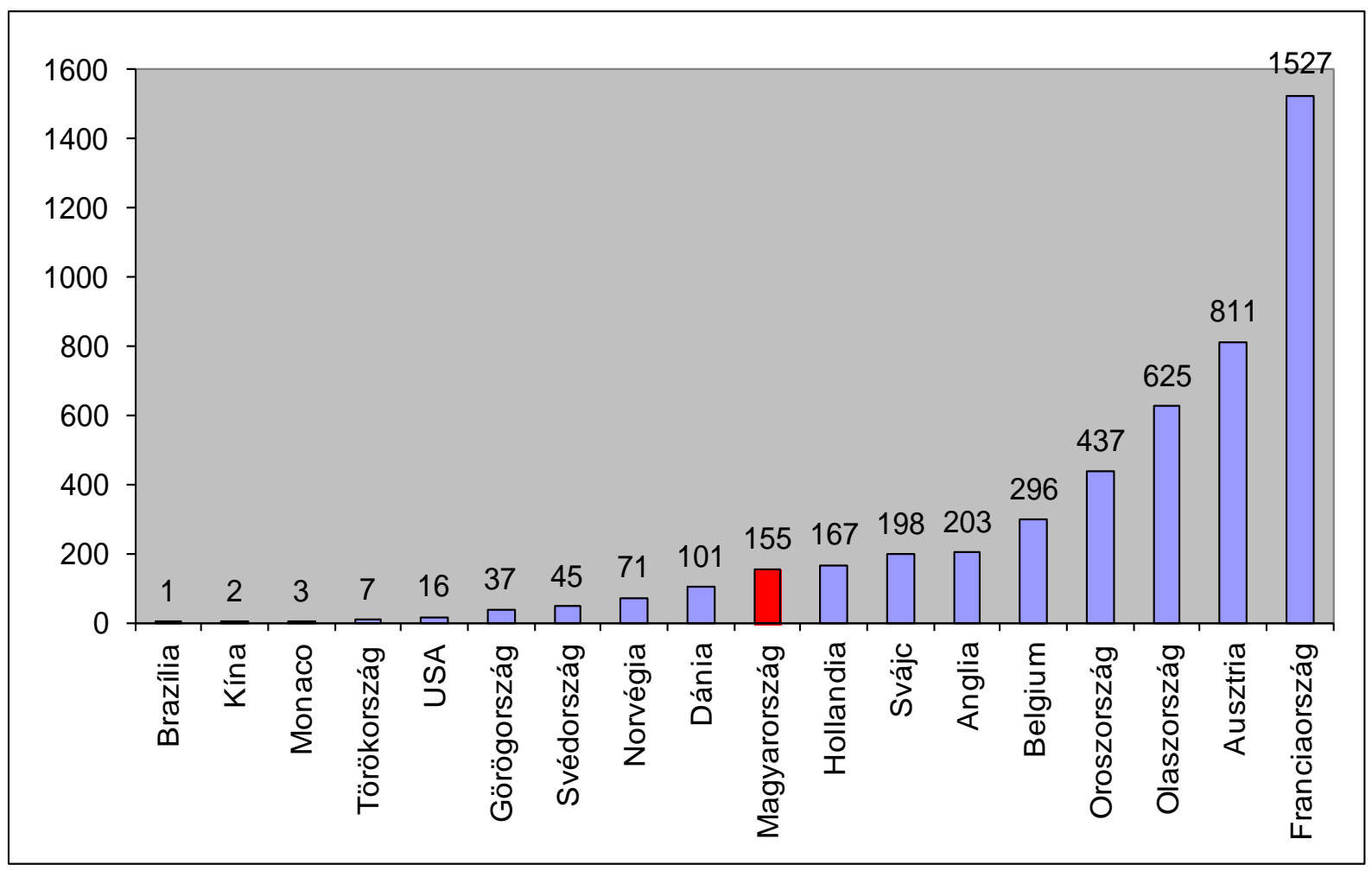

Forrás: Zeitschrift für bildende Kunst, 52. szám, 1873, Október 10. Sammlungen und Ausstellungen, Wiener Weltausstellung. 837.o.

A magyar csoport kitüntetései nem kevesebb, mint tizennégy festő munkáját dícsérték: Munkácsy Mihály, Lotz Károly, Than Mór, Székely Bertalan, Horowitz Lajos, Ligeti Antal, Madarász Győző, Pálik Albert, Paál Laszló, Zichy Mihály, Keleti Gusztáv, Mészöly Géza, Weber Ferenc és Greguss János, ami igen figyelemreméltó a résztvevők teljes létszámát tekintve. ${ }^{545,546}$

\footnotetext{
${ }^{545}$ Städtische Pressburger Zeitung, 1873. augusztus 22., 192. szám, Weltausstellung 1873, An Ungarn verliehene Medaillen und Anerkennungsdiplome. Verzeichnis der Aussteller. Ehrenpreise.

${ }^{546}$ Kitüntetések a magyar mező-gazdaság, ipar, művészet és tudomány az 1873-iki bécsi világkiállításon. Budapest, 1874., 73.o.
} 
A Világkiállítási Közlöny 1872. június 9-én közzétette, hogy a müvészeti szakosztály május 31-én megtartott ülésén a visszajelzések alapján 51 művész résztvételére számíthatott, ami minden várakozást felülmúlt. A magyar festők névsorában Munkácsy neve mellett megtalálható Alexander Liezenmayer vagy Alexander Wagner, illetve a kedvelt cári udvari festő Zichy Mihály, valamint Lotz Károly, Than Mór és Székely Bertalan neve is.

10. sz. ábra A világkiállításon magyar festők által kiállított és ebből eladásra felkínált képek száma

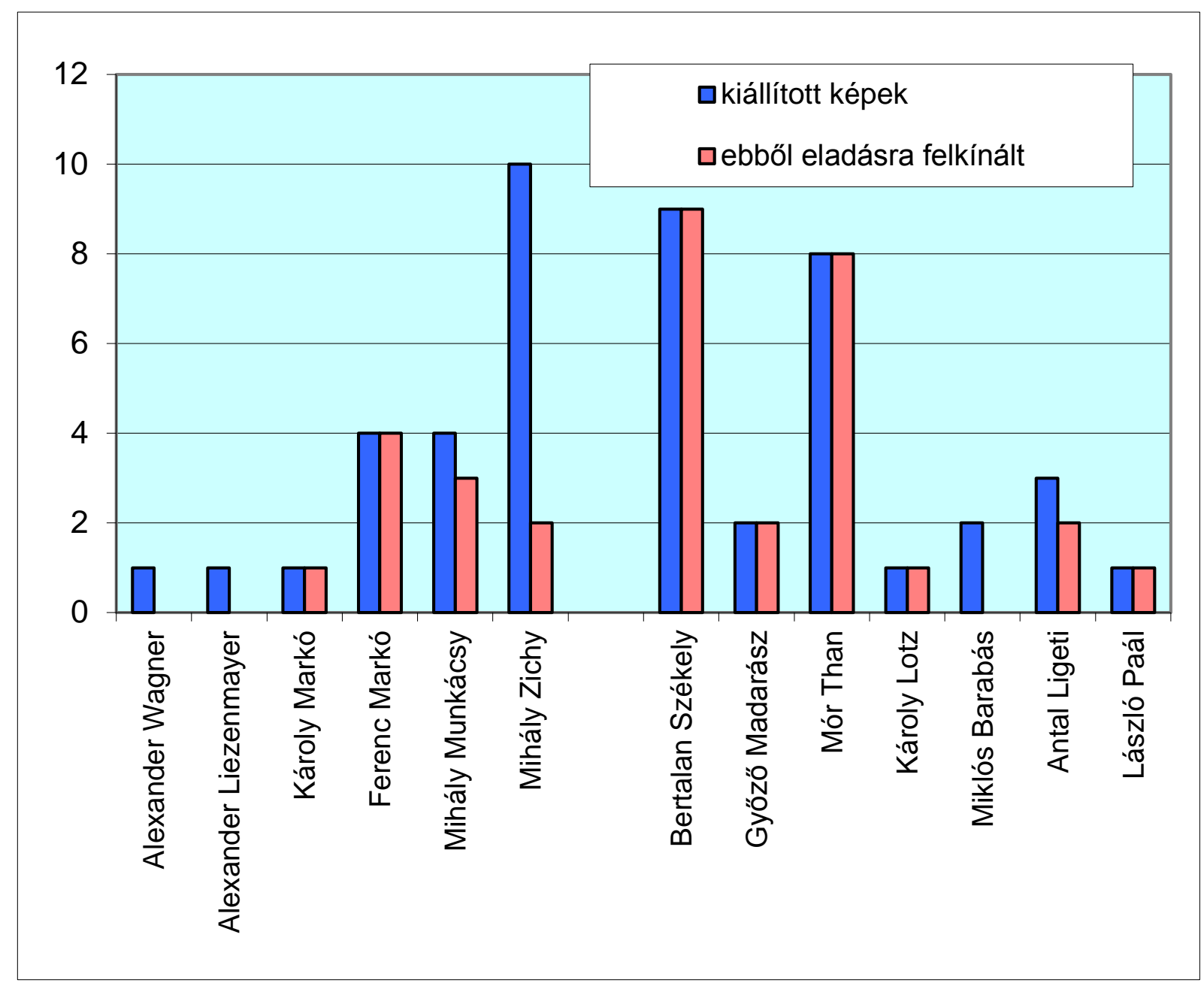

Forrás: Weltausstellung 1873 in Wien. Kunst-Catalog. 1. Kiadás. 68-70.o.

A magyar kiállítómüvészek munkáit mutató diagrammon szembetűnő, hogy míg néhány festő csak kevés munkával szerepeltette magát, amelyek ráadásul a nem megvásárolható 
kategóriába sorolandók voltak, addig más festők nagyszámú, eladásra szánt munkával jelentek meg a nagyközönség előtt. Ezen tények alapján két kategóriát különböztethetünk meg egymástól. Az elsőbe nemzetközi szinten elismert festőket sorolhatjuk, mint: Liesen-Mayer Sándor, Markó Károly, Zichy Mihály és Munkácsy Mihály. Ők elegendő képmegrendeléssel illetve eladással bírtak, nem szorultak a bécsi világkiállítás adta piaci előnyökre. Sokkal inkább a patrióta, hazafias magatartás dominált, amikor müveiket a Magyar Müvészeti Szakosztály termében állíttatták ki. A második kategóriába azon hazai festők találhatóak meg, akik otthoni csekély megrendelései mellett természetesen élni kívántak a világkiállítás adta nagy nemzetközi felvevőpiac lehetőégével és az előző csoporttal szemben rengeteg munkával szerepeltek. Pulszky Ferenc a Borsszem Jankó stílusában közölt mondatai tehát nem túloznak, ${ }^{547}$ amikor arra hívják fel az olvasó figyelmét, hogy a hazai müvészeti életben müvészeink kénytelenek feladni művészeti pályájukat feláldozva más, a mindennapi kenyeret biztosító fogalalkozások oltárán, melynek egyike az egyre nagyobb teret hódító fényképészet is. Kiváló példája ennek Borsos József, aki a világkiállítás alkalmával nem állított ki festményt, hiszen ekkor már jó ideje fényképészként dolgozott. A bécsi világkiállításon pedig ,jó ízlés“ kategóriában elnyert világkiállítási éremmel jutalmazták. ${ }^{548}$

A bécsi világkiállítás keretében hét kategóriában lehetett medáliákat kapni. ${ }^{549} \mathrm{Az}$ aranyérmek elkészítésére pályázatot írtak ki 1872. márciusában amelyre nemcsak

\footnotetext{
${ }^{547}$ Borsszem Jankó, 6. évf. 274. szám. 1873. március 30. Magyarország a világtárlaton; Népszerü felolvasások. III. Pulszky Ferencz. A Borsszem Jankó úságírója, Pulszky Ferenc előadása kapcsán a következőképpen emlékezett meg napjaik magyar építészetről, szobrászatról és a festészetről valamint annak érezhető hatásáról: "Napjainkban az építészetet a czukrász, a szobrászatot csak a gipszes olasz gyakorolja, míg a festészet a fotográfus kalitkájába szorult, melyre nézve az ókori Pindar így nyilatkozott: ez a fény árnya!“

${ }^{548}$ Farkas Zsuzsanna (2009) Embermásoló. Borsos József festőmüvész fényképeinek története.Magyar Fotográfiai Múzeum, Kecskemét, 1193.o.

${ }^{549}$ Weltausstellung 1873 in Wien.Offizielle Programme und Publicationen. Nr. 76. XXI. 4.o.: 1. das Ehrendiplom der Weltausstellung in Wien, A bécsi világkiállítás díszoklevele; 2. die Fortschrittsmedaille, Haladásért járó érem; 3. die Verdienstmedaille, Érdemérem;4. Kunstmedaille, Müvészetért járó érem;
} 
belföldi, hanem külföldi müvészek is pályázhattak. Az alábbi érmekre lehetett a világkiállításon pályázni: „Die Kunstmedaille“, müvészetért járó érem, majd a „Fortschritt medaille“, azaz az előrehaladásért járó éremért, amelyet azok a kiállítók kaphattak, akik valamely korábbi világkiállításokon részt vettek és azóta jelentős fejlődést mutattak. ${ }^{550}$ Azok a kiállítók, akik munkájukkal első ízben vettek részt világkiállításon, a jó ízlés kategóriájában nevezhettek „Medaille für guten Geschmack“. Minden érmet ugyanabból az anyagból készítettek, jelen esetben bronzból, amelyeknek mérete is megegyezett. “551,552 A világkiállítás éremtervezésének pályázati felhívására ${ }^{553}$ a Bécsi Világkiállítási Lexikon adatai alapján sokan pályáztak. A zsűri tetszését végül Josef Tautenhain ${ }^{554}$ pályázata nyerte el a képzőmüvészeti érem megtervezésére, Rudolf

5.die Medaille für guten Geschmack, Jó ízlésért járó érem; 6. die Medaille für Mitarbeiter, Munkatársak számára járó érem;7. das Anerkennungs-Diplom., Elismerő oklevél.

${ }^{550}$ Weltausstellung 1873 in Wien. Offizielle Programme und Publicationen, 11.szám, Concurs für die Anfertigung der Preismedaillen. (Verzeichnis der Mitglieder der Jury zur Beurteilung der Modelle.) 1.o.

${ }^{551}$ Weltausstellung 1873 in Wien. Offizielle Programme und Publicationen 11.szám, Concurs für die Anfertigung der Preismedaillen. (Verzeichnis der Mitglieder der Jury zur Beurteilung der Modelle.) 2.o.

„A világkiállítási érmek előírásai a következők voltak: mind az öt érmen a császár portréjának kellett szerepelnie a következő bevéséssel:“I. Ferenc József Osztrák Császár, Cseh Király, Apostoli Magyar Király.“Az érem hátlapját a nyertes pályamủ díszítette, bár ezen fel kellett tüntetni a kategóriát, amelyben a sikert elérte. Az érem peremén a müveszeti kategóriában a következő feliratnak kellett állnia: „Világkiállítás 1873 Wien“

${ }^{552}$ Weltausstellung 1873 in Wien. Offizielle Programme und Publicationen, 11.szám, Concurs für die Anfertigung der Preismedaillen, 3.o

„A zsüri döntését abszolút többségi szavazással hozta. A nyertes pályázatot tizenöt osztrák dukáttal honorálták.“

${ }^{553}$ Weltausstellung 1873 in Wien. Offizielle Programme und Publicationen, 46.szám, Concours für die Anfertigung der Preismedaillen. (Verzeichnis der Mitglieder der Jury zur Beurteilung der Modelle.), 1.:,A világkiállítási érmek pályázói egy tizenkét tagú zsűri előtt mérettettek meg, akikből részarányosan hárman a világkiállítási bizottságból, hárman a Császári és Királyi Képzőművészeti Akadémiáról, továbbá hárman a Császári és Királyi Mủvészeti és Ipari Múzeumból illetve hárman a Képzőművészeti Egyletből delegálták.“

${ }^{554}$ Josef Tautenhain (1837-1911), osztrák szobrász és éremkészítő. 
Weyr ${ }^{555}$ pedig a Jó ízlésért, végül Karl Schwenzer ${ }^{556}$ pedig a „Für Fortschritt und für Mitarbeit“, azaz a „haladásért és a közremüködésért“ érmet tervezhette meg. Megemlítendő továbbá, hogy a magyarok a 27 nemzetközi zsüri 27 föcsoportjában

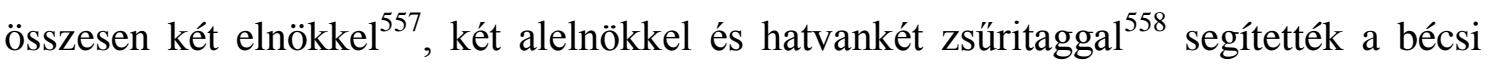
világkiállítás szakmai munkáját.

\subsection{Munkácsy Mihály múvészetének elismerése a Ferenc József Rend tükrében.}

Munkácsy Mihály kiállított müveivel nemcsak a világkiállítás közönségének figyelmét, hanem a császári udvar kitüntetett kegyét is elnyerte. Világkiállítási éremmel jutalmazott munkája mellett az uralkodó további elismerésül a Ferenc József rendet/lovagkeresztet ${ }^{559}$ adományozta a fiatal festőnek. A Ferenc József Rendjel alapítása Ferenc József 1849. december 2.-i trónralépésáhez kötődik. A rend öt kategóriában létezett: nagykereszt, csillaggal övezett középkereszt, középkereszt,

\footnotetext{
${ }^{555}$ Rudolf Weyr (1847-1914), osztrák szobrász.

${ }^{556}$ Karl Schwenzer (1843-1904), würtenbergi király udvari éremkészítő.

${ }^{557}$ Gróf Zichy Henrik (1812-1892), a Sporon megyei mezőgazdasági egyesület elnöke, a nemzetközi zsűri 4. csoportjának (ipari élemiszeri és élvezeti cikkek) elnöke; báró Orczy Béla (1822-1917), A császári és királyi külügyminisztérium osztályvezetője, a nemzetközi zsűri 20. csoportjának (parasztház belső berendezései) elnöke

Städtische Pressburger Zeitung, 143. szám, 1873. június 24., Die ungarischen Jury-Mitglieder der Wiener Weltausstellung.

${ }^{558}$ Städtische Pressburger Zeitung, 143. szám., 1873.június 24., Die ungarischen Jury-Mitglieder der Wiener Weltausstellung.

${ }^{559}$ Képes Kiállítási Lapok, Új folyam, 1873. december 21., 135.o.
} 
valamint tiszti és lovagkereszt. ${ }^{560}$ A rendjel kizárólag művészek, gyárosok, iparosok, politikusok és a polgárság kiemelkedő egyéniségeinek volt adomanyozható. ${ }^{561}$

A magyar külügyminiszter által a Ferenc József érdemrendre javasolt magyar kiállítókat a következő mondatokkal ajánlotta az uralkodó figyelmébe: ,[...] az érintettek önzetlen patriotizmust mutattak, amennyiben a kedvezőtlen pénzügyi és kereskedelmi viszonyok között nem a pénzügyi hasznot nézték, hanem egyedül az ország érdekeit tartották szem előtt.“ A kitüntetésjavaslatok összeállításakor a miniszter nemcsak a kiállításon elért érdemeket, hanem az érintettek társadalmi státuszát is figyelembe vette. Ezen túlmenően azokat az egyéneket, akik a keresekedelem, ipar és mezőgazdaság területén elért jelentős szolgálataik miatt már korábban is kitüntetésre édemesnek találtattak.

Munkácsy Mihály kitüntetésének megindoklásául a következő mondatot olvashatjuk a magyar kereskedelemügyi miniszter felterjesztesében: Munkácsy Mihály híres, Európában is elismertnek számító festő. ${ }^{562}$ Megemlítendő, hogy Munkácsy Mihályon kívül Lotz Károlynak es Telepy Károlynak, ${ }^{563}$ a Magyar Müvészeti Egylet Titkárának ugyanezt a kitüntetést adományozták, akik ennek köszönhetően Munkácsyval együtt az Osztrák Császári Ferenc József Rend lovagjai lettek. ${ }^{564}$

\footnotetext{
${ }^{560}$ Schwarz, Walter A. (2005), Vergänglicher Glanz... “Altösterreichs Orden. Katalog zur Ausstellung des Österreichischen Staatsarchiv und der Österreichischen Gesellschaft für Ordenskunde (ÖGO) anlässlich deren 15- jährigen Bestandsjubiläums, Haus-, Hof- und Staatsarchiv, 5. mai bis 7. oktober 2005., Österreicherischer Staatsarchiv, 28.o.

${ }^{561}$ Schwarz (2005), 9.o.

${ }^{562}$ Báró Orczy Béla magyar királyi miniszter a következőképpen indokolta Munkácsy Mihály a FerenzJózsef lovagi kereszt kitüntetésre való felterjesztését: Munkácsy európai jelentő festő. Magyar Országos Levéltár. Fond: K.21. 1880-9751. Báró Orczy Béla Ö Felsége személye körüli magyar királyi miniszter elöterjesztése.

${ }^{563}$ HHStA: Archiv Franz - Joseph- Ordens. Kt.23. ,1873:641, F.J.O. Revers von Michael Munkácsy. 1874 február 21. Paris, 1,5, 6.o.

${ }^{564}$ HHStA.Kabinettskanzlei - Vorträge, Franz-Josephs- Orden. 1873: 4479., 1873. december 6.
} 


\section{Munkácsy Mihály avagy múvészi hírnév és nemesség}

Munkácsy Mihály festőművész pályájának felívelése a Siralomház címü festményének megalkotásával (1868) vette kezdetét, melyet 1870-ben a Párizsi Szalonon aranyérmmel tüntettek ki. Három évvel később, 1873-ban a bécsi világkiállitás alkalmával Munkácsy Mihály már európai hírü elismert, divatos festőnek számított, melyet a müértő, illetve a müvészet iránt érdeklődő laikus közönség festménymegrendelései híven tükröztek. A siker visszhangja töretlenül emelte Munkácsy Mihály müvészetének súlyát a müvészvilágban. Ezt mi sem bizonyítja jobban, mint hogy a Weimari Egyetem professzorainak sorába emelte volna a festőt (Pauwels professzor helyére), felkínálva egy professzori katedrát, amit a festő utóbb nem fogadott el, székhelyének továbbra is Párizs városát választva. ${ }^{565} \mathrm{~A}$ bécsi világkiállitás első ízben nyújtott alkalmat arra, Andrássy Gyula fellépésének illetve az 1867-es kiegyezési politikának köszönhetően, hogy a magyar kiállitók, ezen belül is a müvészek, önállóan immár hazájukat képviselve állíthassák ki műveiket. A bécsi világkiállítás közönsége így elsőként láthatta egy csokorban az akkori magyar festőelit alkotásait. Munkácsy Mihály leveleiből kitünik, hogy a kiállításon magyarként való részvétel a művész számára megkérdőjelezhetetlen volt. Patrióta magatartása már tanulóévei alatt is sok külsőségben megnyilvánult, Münchenben például olyannyira, hogy ez egynémely magyar festőtársa számára egyenesen megbotránkoztató volt. Több magyar, de külföldi akadémiákon tanult müvészünk számára müveiknek a magyar kiállítóteremben való szerepeltetése nem volt egyértelmü. Tekintve a magyar müvészet hazai intézményeit, a külföldi akadémiákhoz

\footnotetext{
${ }^{565}$ Zeitschrift für bildende Kunst (1872), Kunst Chronik, Beiblatt zur Zeitschrift für bildende Kunst, Personalnachrichten „B. Michael Munkacsy in Düsseldorf hat einen Ruf als Professor und Lehrer der Großherzoglichen Kunstschule in Weimar erhalten und angenommen. Er wird dort die Stelle des ausscheidenden Professor Pauwels übernehmen.“, 66-67.o.
} 
képest való nagyfokú elmaradásátt ${ }^{566}$, jogosan érezhették, hogy műveik megítélése azaz ezeknek a magyar teremben való szerepeltetése nem lel sem ez alkalommal, sem a későbbiekben jó visszhangra.

Félretették tehát patriótizmusukat és külföldi akadémiájuk képviselőiként állították ki műveiket. Ezen festők közül kiemelhető. Szinyei Merse Pál, aki a műveit jutalmazó éremmel a német éremtáblázatot gazdagította. ${ }^{567}$ Egy pillatást vetve a magyar kiállító festőmüvészek névsorára, a magyar küldöttségnek egyáltalán nem volt miért szégyenkeznie, hiszen Munkácsy neve mellett megtalálható a két müncheni professzor, Alexander Wagner és Alexander Liezenmayer, valamint a kedvelt cári udvari festő Zichy Mihály tovabbá a Magyarországon nagy müvészi tekintéllyel bíró Lotz Károly, Than Mór és Székely Bertalan neve is. ${ }^{568}$

Munkácsy Mihály számára a bécsi világkiállításon való részvétel komoly próbatételt jelentett, hiszen festményeinek a magyar teremben való kiállításával saját honfiai előtt is tisztelegni kívánt, nagyon szomjazva a hazai elimerő szavakat, amelyek nem is várattak sokáig magukra. Munkácsyn kívül a világkiállításon éremmel kitüntetett festőművészek névsora (Lotz Károly, Than Mór, Székely Bertalan, Horowitz Lajos, Ligeti Antal, Madarász Viktor, Pálik Albert, Paál László, Zichy Mihály, Keleti Gusztáv, Meszöly Viktor, Weber Ferenc és Gregus János.) nem kevesebb, mint 13 festő művészetét

\footnotetext{
${ }^{566}$ Ivett Polenyák (2010), Die Rolle des Mäzenatemtums im Spiegel der österreichischen und ungarischen Kunstvereine im 19. Jahrhundert. 466-478. o. In: Milan Hlavačka, Magdaléna Pokorná and Tomáš W. Pavlíček eds. (2010), Collective and Individual Patronage and the Culture of Public Donation in Civil Society in the 19th and 20th Centuries in Central Europe, Prague.

${ }^{567}$ Verzeichnis der Aussteller. Ehrenpreise.,,900 bis 901 Szinyey Paul von, deutsches Reich, Königr. Bayern, München, Malerei, 452.o.

${ }^{568}$ Barabás Miklós, Baumgartner János, Brodszky Sándor, Bruck Lajos, Gerhard A., Greguss János, Grim Rudolf, Gross Albert, Grosz Béla, Guttmann János, Horovitz L., Horovitz Leopold, Horovitz Ludwig, Ivanovits Katharina, Keleti Gusztáv, Kern Hermann, Kovács Mihály, Kratzmann Gusztáv, Alexander Liezenmayer, Ligeti Antal, Lotz Károly, Löschinger Zsigmond, Madarász Viktor, Markó Ferenc, Markó Károly, Mészőly Viktor, Munkácsy Mihály, Paál László, Palik Albert, Sajossy Alajos, Schimmert S., Siko Miklós, Székely Bertalan, Szoldatich Ferenc, Than Mór, Ujházy Ferenc, Valentini János, Vastag György, Voitag György, Zahoray János, Zichy Mihály, Alexander Wagner, Weber Ferenc.
} 
dícsérte, ami igencsak figyelemremeltó a résztvevők teljes létszámát tekintve. ${ }^{569} \mathrm{~A}$ császári udvar ugyancsak felfigyelt a fiatal magyar festőre, Munkácsy Mihályra és elismerésének kifejezésekent kitüntetésben részesítette, ami a Ferenc József Rendjel adományozásában nyilvánult meg.

A világkiállítások sorában a bécsit a párizsi követte 1878-ban, amin Munkácsy "Milton" cimü híres festményével szerepelt. A festményt éremmel jutalmazták mintegy utat nyitva ezzel a további kitüntetések sorának. Ezek közül is kiemelkedő a Habsburg-ház részéről megnyilvánuló azon kegy, amelynek köszönhetően a Vaskorona Harmadosztalyú Rendjelet adomanyozták a festőnek. Indoklásul pedig a következő mondatot olvashatjuk az adomanyozó okiratban: „Müvészi tevékenységének elismeréséül.“570 A Vaskorona rendjelet még első Napóleon császár alapította 1805. június 5-én, megemlékezve ezzel milánói koronázására, amit I. Ferenc császár 1816. január elsején új néven Osztrák Vaskorona Érdemrendre neveztetett át és ezentúl már nem csak civileknek, hanem katonák számára is adomanyozhatóvá tette. ${ }^{571}$ Munkácsyt már 1878. szeptember 10-én a Bécsi Képzőmüvészeti Akadémia tiszteletbeli tagjává választották. ${ }^{572}$

A párizsi aranyérmet nyert híres festménye, a Milton, 1879-ben lett Bécsben kiállítva. Munkácsy Mihály festménye a bécsi közönség körében is nagy sikert aratott és ezúttal sem kerülte el a császári ház figyelmét, amelynek fényét a császárné személyes érdeklődése még tovább emelt. Egy korabeli híradásból megtudhatjuk, hogy a császárné Goess grófnő társaságában hosszan időzött Munkácsy kiállított festménye előtt. ${ }^{573}$

\footnotetext{
${ }^{569}$ Städtische Pressburger Zeitung (1873), Weltausstellung 1873, An Ungarn verliehene Medaillen und Anerkennungsdiplome. Nr. 192., 22. August 1873. Verzeichnis der Aussteller. Ehrenpreise.

${ }^{570}$ MOL. Fond: K.21., 1880-9751. K.21. 1880-9751. Báró Orczy Béla Ö Felsége személye körüli magyar királyi miniszter elöterjesztése.

${ }^{571}$ Schwarz (2005), 26.o.

${ }^{572}$ HHStA. Kabinetskanzlei-Vorträge 1878: 4252.

${ }^{573}$ Magyar Nemzeti Galéria, „Die Kaiserin im Künstlerhaus“ 2092/75, 1879. „Die Kaiserin, eine besondere Verehrerin des ungarischen Malers, besuchte Vorgestern in Begleitung der Gräfin Goeß das
} 
Munkácsy Mihály pályájának szokatlanul gyors felívelése, majd ezzel egyetemben gyors megjelenése az európai jelentősegű festők sorában, szinte példanélküli a magyar művészettörténelemben, hiszen Munkácsy művészete nem csak egy-egy európai országban, hanem egész Európában ismertté vált. Az immár Fortuna kegyeltjének számító és ennek fényében fürdő magyar festő szokatlan kéréssel fordult a császári házhoz, amire nemigen volt példa sem müvészi, sem pedig civil körökben. Egy olyan folyamodványt nyújtott be a minisztériumba, amelynek értelmében a neki ajánlott Vaskereszt érdemrendet magyar nemesi címre cserélné. ${ }^{574,575}$ A folyamodványra reagálva báró Orczy Béla a király személye körüli miniszter előterjesztésében elismeri, hogy az alapszabályok az osztrák lovagi rend birtoklása ellenére sem jogosítják fel a kérelmezőt a magyar nemesség becserélésére, azonban Munkácsy Mihály érdemeire tekintettel továbbítja illetve támogatja a kérelmező kivánságát az alább idézett mondatokkal:

„Minthogy azonban folyamodó a művészet terén tényleg oly kiváló érdemeket szerzett, hogy neve világszerte ismeretes, és a haza díszére való honfiak sorába méltán számítható, - minthogy továbbá Munkács városa is a 3/. alatti főispán jelentése szerint oda nyilatkozott, hogy a munkácsi előnév adományozása ellen észrevétele nincsen, sőt folyamodót a város díszpolgárává is megválasztani fogja,- az említett ministeriumvezetője méltányosnak véli, hogy folyamodó - a munkácsy előnévvel járó magyar nemességel leendő kitüntetés czéljából Felségednek melegen ajánltassék. “576

Künstlerhaus und verweilte längere Zeit vor dem erwähnten Kunstwerke, über welches sich die hohe Frau in den lebhaftesten Ausdrücken der Bewunderung äußerte.“

${ }^{574}$ MOL. Fond: K. 21., 1880- 9751, 18.o.

${ }^{575}$ Polenyák Ivett (2011), „Munkácsy Mihály, avagy művészi hírnév és nemesség“, In: Antos B., Tamás Á. (eds): Szemelvények ötszáz év magyar történelméből, Szegedi Tudományegyetem, Szeged.

${ }^{576}$ MOL. K.21. 1880-9751. „[...] Folyamodásának azon kérelme- hogy a rendi alapszabályok folytán magyar nemesi rangra emeltessék- az e részben meghallgatott magyar belügyi ministerium vezetöjének m. hó 24 én 4865 szám alatt kelt s 2/. Alatt hódolatteljesen die rekesztett hivatalos átirata szerint nem teljesíthetö ugyan-mert az említett rend birtoka a magyar nemességre igényt nem ád, s az alapszabályok az osztrák lovagi rendnek a magyar nemesség általi helyettesítését sem állapíthatják meg. Minthogy azonban folyamodó a müvészet terén tényleg oly kiváló érdemeket szerzett, hogy neve világszerte 
A szokatlan kérelem illetve ennek legfelsőbb, minisztériumi szinten való támogatása, majd a kérés teljesítése híven tükrözi Munkácsy Mihály európai hírnevét és a felsőbb magyar társadalmi körökben is érzékelhető popularitását. 1880. augusztus 7-én Munkácsy Mihály átvehette a királyi nemes levelet Párizsban ${ }^{577}$, bár az engedélyt hivatalosan már 1880. december 11-én jóváhagyták. ${ }^{578}$ Munkácsy a párizsi nagykövet közremüködésével köszönte meg a császári kegyet ${ }^{579}$, amit a követség továbbított a császárnak. $^{580}$

A nemesi címhez adományozott címer híven tükrözi tulajdonosa művészi érdemeit. Az adományozott címer vagy címerpajzs vertikálisan két egyenlő részre van osztva. A címer jobb oldali része vörös, míg a bal oldali része kék színü. A címermező közepén a nyugat-európai mintáknak megfelelően cimerábra, egy griff található. A griff ábrázolasának célja a címer tulajdonosának a tetteinek a megörökítése. A griffmadár, melynek feje, nyaka és szárnyai egy sastól, a fennmaradó részei pedig egy oroszlántól származnak, a tulajdonos bátorságát hivatott szinbolizálni. Az aranyozott griff a címerekben tipikus testtartásaban került ábrázolásra Munkácsy címerében: a hatsó lábán állva az elülsőt elöre nyújtja és nyitott csőrén keresztül piros nyelvét kinyújtja. Ezen testtartás ábrázolása hivatott kifejezni Munkácsy rátermettségét, bátorságát, hősiességét, melynek erdménye a nemzetközi müvészvilágban való elismertsége. A címeren égitestek (csillagok illetve egy félhold) is láthatóak, amelyek így az univerzumot, azaz a festő nemzetközi elismertségét hivatottak tükrözni. A Munkácsy címer esetében egy nyitott sisakról, ún. rostélyos sisakról beszélhetünk. A 18-19. századi bécsi udvari szabályoknak megfelelően Munkácsy a többi nemeshez hasonlóan egy sisakot kapott,

ismeretes, és a haza díszére való honfiak sorába méltán számítható, - minthogy továbbá Munkács városa is a 3/. Alatti föispán jelentése szerint oda nyilatkozott, hogy a munkácsi elönév adományozása ellen észrevétele nincsen, söt folyamodót a város díszpolgárává is megválasztani fogja,-az említett ministeriumvezetöje méltányosnak véli, hogy folyamodó-a munkácsy elönévvel járó magyar nemességel leendö kitüntetés czéljából Felségednek melegen ajánltassék.“

${ }^{577}$ MOL. K21., 1880-9751. Elismervény.

${ }^{578}$ HHStA: Gesandtschaftsarchiv 5113 Szám/ eln. 21/12 880.Budapest, 1880. december 16.

${ }^{579}$ HHStA: 5113 Szám/ eln. 21/12 880.Munkácsy Mihály levele.Paris, 1881. január 16.

${ }^{580}$ HHStA: Gesandtschaftsarchiv, 384 szám/eln. Budapest, 1881. február 5. 
szemben a grófoknak es báróknak járó kettő illetve három sisakkal. A sisakdísz azonos a pajzson látható címerképpel, azaz a griff madárral. Más nemesi címerekhez hasonlóan a sisak felett egy színes levélformajú koronával ellátott díszítés található. Összefoglalásképpen megállapítható, hogy Munkácsy címere a bécsi udvar heraldika szabályait követi, de egyben megfelelően tükrözi a festőművész egyedi jegyeit is. Az okiratban szereplő Munkácsy előnév használatát immár hivatalosan is engedélyezte a belügyminisztérium, melyet ezeddig a müvész csak müvésznévként használt, de mint az okiratból kiderül, Munkács városa büszkán hozzájárult ehhez. ${ }^{581}$ Művésznevének vagyis immár nemesi neve a szülővárosához füződő szeretetből illetve patriotizmusából fakadt, amiről a festő saját maga beszélt első és egyben legjelentősebb életrajzírójával, F. Walter Ilges-szel. ${ }^{582,583}$

A bécsi közönségnek az 1873-as világkiállítás után kilenc évet kellett várnia, hogy ehhez hasonló nemzetközi kiállítást tekinthessen meg. Az 1882-ben megnyílt Bécsi Mủvészház termeiben több, mint 500 müremek került a nagyközönség elé. A munkák Belgium, Svédország, Hollandia, Dánia, Anglia, Spanyolország, Norvégia, Franciaország, Olaszország és Németország müvészeinek munkáit dícsérték. Munkácsy Mihálynak feltünően sok alkotása volt látható. Ezzel kapcsolatban egy korabeli kritikus igen találóan jegyezte meg, hogy a kiállítás tulajdonképpen egy Munkácsy kiallításnak is beillett volna. ${ }^{584}$ Munkácsy Mihály müvészete nemzetközi szinten és ismét Bécsben megmérettetett, amely a töretlenül emelkedő hírnevü festőt „Krisztus Pilatus előtt“ című

\footnotetext{
${ }^{581}$ MOL. K.21. 1880-9751. Báró Orczy Béla magyar királyi miniszter előterjesztése.

${ }^{582}$ Ilges, F. Walter (1899), M. Von Munkacsy, Verlag von Velhagen \& Klasing, Bielefeldund Leipzig, 28.o.

${ }^{583}$ Sajnos a magyar Munkácsy monografiák írói méltánytalanul figyelmen kívül hagyták Ilges munkásságát, amire az egyetlen magyarázat talán annak gót betűvel megírt német nyelvű könyve, hiszen a magyar monográfiák kilencvenkilenc százaléka az ötvenes évek után íródott, a Szana Tamás által megírt első magyar monográfia pedig csak nagyvonalakban példálózik afenntebb említett munkával. Ezt a hiányt doktori dolgozatomban pótoltam.

${ }^{584}$ Kunst Chronik. (1882), Beiblatt zur Zeitschrift für bildende Kunst.1882, Sammlungen und Ausstellungen. Österreichischer Kunstverein, 257.o.
} 
festményével a kiállítás aranyérmével jutalmazta ezzel is méltan sorolva Európa legnagyobb festőfejedelmei közé. 


\section{A Kunsthistorisches Museum kupolaképe}

A Habsburg-udvar felkérésére sokat kellett Munkácsynak várnia. A „Siralomház“ sikere után tizenhat évnek kellett eltelnie. Hans Makart halála után bízták rá a Kunsthistorisches Museum mennyezetképének a megfestését. Hohenlohe herceg, főudvarmester 1886 novemberében kelt levelében Bécsbe invitálta a festőt, hogy ennek művészeti kivitelezését és pénzügyi kereteit megbeszéljék. ${ }^{585} \mathrm{~A}$ megbízólevélben pontosan leírták a mü méreteit, nagyságát, szélességét, valamint elkészültének határidejét. ${ }^{586}$ Előirták a mennyezetfestmény kompozícióját csakúgy, mint a múzeum többi díszítőfestményét is a kivitelező festők számára. Hans Makart, Munkácsy Mihály bécsi barátja nyerte el a megbízást eredetileg, de a kép megfestésében betegsége, majd halála megakadályozta. A mennyezetképet 12, fülkékbe helyezett kisebb kép szegélyezi. Ezeket a kisebb festményeket Makart még be tudta fejezni, a mennyezetképnek pedig elkészítette a vázlatait. ${ }^{587}$

Makart vázlatai szerint a kupolába helyezendő festmény többek között minden idők festőiskolái közül tízet szimbolizál: „Hans Makart professzor, aki ezt a feladatot magára vállalta, ennek a megrendelésnek a szerves részét képező 12 félkör alakú festményt készített, de a nevezett mennyezeti festményről csak egy vázlatot hagyott maga után. Ezekből 10 kép minden idők legkiválóbb festőiskoláinak a képviselőit ábrázolja. Az elkészítendő mennyezetfestménynek az ábrázolt személyek méretét tekintve és általában

\footnotetext{
${ }^{585}$ HHStA., Obersthofmeisteramtsakten Kt. 1113 r. 50/9/1, 1886:4929.: „Lieber Herr Munkácsy, mit großer Freude hab ich erfahren, daß Sie wären, die Ausführung des Deckengemäldes im Kunsthistorischen Museum zu Wien auszuführen.“

${ }^{586}$ „Die Bildfläche:10.119 Meter auf 10.879 Meter.[...] die Bildrahmen im Maaß von 10.985 auf 10. 225 Meter.[...] von Mittelpodest der Stiege bis zum gegen Mittelbildes 17.069 Meter betrugt. [...] Das Gemälde musste bis Ende d. J. 87 fertig an Ort und Stelle sein.“ HHStA., Obersthofmeisteramtsakten Kt. 1113 r. 50/9/1, 1886:4929.

${ }^{587}$ HHStA., Obersthofmeisteramtsakten Kt. 1113 r. 50/9/1, 1886:4929.
} 
véve is a félkör alakú festményeihez kell lehetőség szerint kapcsolódnia. “" ${ }^{588} \mathrm{Ez}$ a hivatalos megbízatás bizonyítja, hogy Munkácsynak Hans Makart vázlatait kellett felhasználnia a festmény megfestéséhez! A Kunsthistorisches Museumban megfestendő képekről pedig a Bécsi Főépítészegyesület döntött. Makart tervezett festményeinek a vázlatát már ismerte a bécsi művészetért lelkesedő közönség, hiszen azokat még 1885ben egy kiállítás alkalmából a „Város szépészet“" pavilonjában kiállították. ${ }^{589}$ Munkácsy Mihály 1887-ben tekintette meg Makart vázlatait, melyekről elismerően nyilatkozott. ${ }^{590}$ Az Allgemeine Kunst-Chronik közlése szerint báró Karl von Hasenauer személyesen mutatta meg a félkör alakú festményeket és felhívta Munkácsy figyelmét arra, hogy a kőrkép, ami Rembrand idejét és iskoláját hivatott bemutatni, és amihez Makart a nagyszerü németalföldi Belvedere-ben található kiváló önarcképét használta fel, túlságosan sötét és a mester feje az ábrázolt távolsághoz képest nem emelkedik ki élesen a háttérből. ${ }^{591}$ Munkácsy a fóépítész kérésének ellenére azonban nem változtatott

\footnotetext{
${ }^{588}$ HHStA., Obersthofmeisteramtsakten Kt. 1113 r. 50/9/1, 1886:4929.: „[...] Professor Hans Makart, welchem diese Aufgabe übertragen war, hatte 12 Lünetten Bilder, die einen integrierenden Theil dieser Bestellung bildeten, vollendet, für das genannte Deckenbild aber nur eine Skizze hintergelaßen. Von diesen Bildern symbolisieren 10 die Repräsentanten der hervorragendsten Malerschulen aller Zeiten und zwei die (pervertieren?) der bildenden Künste. Genannte Lunettenbilder kommen zur Verwendung in Folge dieser müßte das auszuführende Deckengemälde sich sowohl in der Größe der Figuren, als auf im Übrigen der Lünettenbilder möglichst anschließen. Letzte sind in der Deckung bei der Hofmuseum in Aufbewahrung ebenso Makart`s Skizze zum Deckengemälde.“

${ }^{589}$ Die Kunst in Oesterreich-Ungarn. (1885), Makart und kein Ende.Januar 1885, 54.o.: ,[...]Der reiche Sinn für Form und Farbe und eine überquellende Phantasie hat Makart auch hier nicht verlassen, wo es galt, die Aphoteose des grossen Malerfürsten in enger, räumlicher Begrenzung darzustellen.“

${ }^{590}$ Allgemeine Kunst-Chronik. (1890), Munkácsy und Makart. XIV. Bd. Nr. 22. zweites Oktoberheft 1890., 598.o.: „Dass der sterben musste! So wie er, trifft’ s doch kein Anderer!“

${ }^{591}$ Allgemeine Kunst-Chronik. (1890), Munkácsy und Makart. XIV. Bd. Nr. 22. zweites Oktoberheft 1890., 598.o.: „Baron Hasenauer zeigte Munkácsy auch die Lünettenbilder und machte Munkácsy darauf aufmerksam, dass der verstorbene Maler „das Rundbild, welches die Zeit und Schule Rembrandt's versinnbildlichen soll, und für welches Makart das im Belvedere befindliche, ausgezeichnete Selbstporträt des großen Niederländers verwendete, viel zu dunkel gerathen der Kopf des Meisters hebt sich für die Entfernung nicht scharf genug aus dem Untergrunde hervor.“
} 
Makart eredeti elképzelésein! ${ }^{592}$ Saját mütermében három különböző vázlatot készített a megfestendő mennyezetképhez, melyeket barátai is megtekinthettek.

„A képem tárgya a reneszánsz, egy allegória, ami megengedi, hogy a képi ábrázolás számára fontos minden fajta anyagot harmonikusan egyesítsen. A középpontban a művészet géniusza áll majd, egy nagy női alak szélesre tárt szárnyakkal egy pálmalevéllel a kezében. Mögötte fog sorakozni a hírét terjesztő Hírnév és egy pokolfajzat, az Irigység. Ez a központi csoport, amire a hangsúlyt helyezem, kiemelkedik egy fényes felhőböl, ami a kék égboltot ragyogóan megtöri. Balra ez alatt tervezem elhelyezni Medici Lorenzot, amint a Lorenzo müvészudvara által körülvett Michel Angelonak nyújtja a kezét. A géniusz alatt elhelyezkedő középső csoport Tiziant és kedvenc tanítványait ábrázolja, ecsettel és palettával a kézben. Tizian a természetre utal, ami minden müvészet és ábrázolás kiapadhatatlan forrása. A két női alak megmutatja szép alakját. A háttérben lombozat és virágok láthatók, színes madarakkal és pillangókkal. A természet szédítő gazdagsága és változatossága Tiziant a kép jobb részén ábrázolt, ámuló tanítványaival szemben mutat egy világos víziót. Az alsó csoport, több művész kiséretében Sixtus pápát ábrázolja. Ezek a mennyezetfestményem főbb jellemzői. Természetesen nem beszélek a részletekről, az angyalokról, felhőkről és díszítésekről, amik benépesítik a festményt és változatossá teszik azt.“593

Látható, hogy a megfestésre kerülő festményen kevés változtatás történt az eredeti vázlatokhoz képest. A kompozíciót érintetlenül hagyta csak a hátterébe került néhány leegyszerüsített virágzó ág. A „Reneszánsz apotheozisa“ címü képét 1890-ben fejezte be. Maga a festő illetve az ugyancsak nagy hírnévnek örvendő Angeli is elismerően

\footnotetext{
${ }^{592}$ Allgemeine Kunst-Chronik. (1890), Munkácsy und Makart. XIV. Bd. Nr. 22, Zweites Oktoberheft 1890., 598.o.: „Ich werde doch nicht Makart ausstreichen. Wenn ich`s vielleicht anders gemacht hätte, hätte ich`s vielleicht anders gemacht, aber nun es ist so ist, muss es so bleiben!“ Én nem fogom Makartot kitörölni, Ha én talán másképpen csináltam volna, én másképp csináltam volna, de ez most így van, és így is kell, hogy maradjon!“

${ }^{593}$ Allgemeine Kunst-Chronik. (1890), Munkácsy und Makart. XIV. Bd. Nr. 22, Zweites Oktoberheft 1890., 598.o.
} 
nyilatkozott a képről, amit Munkácsy feleségéhez címzett leveléből ismerhetünk meg. ${ }^{594}$ A festményért járó honoráriumot (16. 892. forint 50 krajcár) 1889. augusztus 15-én utalták ki Munkácsy számára. ${ }^{595}$ A Párizsi Salon közönsége is megcsodálhatta a festményt 1890-ben. A francia kritikusok elismerően nyilatkoztak a kiállított müről, amit a Salon aranyérme, valamint a Becsületrenddel (Kommandeur der Ehrenlegion) való kitüntetés is bizonyít. A császári elismerés sem váratott sokáig magára, Munkácsy Mihályt a „Ehrenzeichen für Kunst und Wissenschaft”, kitüntetés a Művészetért és Tudományért Érdemrenddel jutalmazták. Ferenc József, 1887. augusztus 20-án alapíotta a „Ehrenzeichen für Kunst und Wissenschaft“" kitüntetést. Ebben az elismerésben azok a művészek is részesülhettek, akik nők voltak vagy nem voltak a Monarchia polgárai. ${ }^{596,597}$ 1887-ig csak hírneves személyeknek adományozták. ${ }^{598}$ A medál egyik

\footnotetext{
${ }^{594}$ Ilges (1899), 97.o.: „Der Plafond macht sich in der That gut und all` unsere Furcht wegen Perspektive und Architektur war unbegründet. Auch Angeli, der den Plafond in Paris gesehen und seine Frucht betreffend der Architektur ausgesprochen hat, ist völlig zufrieden gestellt und gesteht, daß ich mich nicht getäuscht habe....kurz und gut, ich hoffe, daß ich Erfolg und mich nicht umsonst gequält haben werde.“

${ }^{595}$ Wiener Stadtsbibliothek. N. 161.972. Munkácsy Mihály.

${ }^{596}$ Wiener Allgemeine Zeitung (1887), Sechsuhr-Abendblatt. Nr. 2685., 20. August 1887. Wien, 1-2.o.

${ }^{597}$ Wiener Allgemeine Zeitung (1887), Morgenblatt. Nr. 2686.Inland-Das Ehrenzeichen für Kunst und Wissenschaft. 21. August 1887, 2.o.

${ }^{598}$ Professor an der Akademie der bildenden Künste in Wien, Maler, Heinrich v. Angeli, Präsident der Akademie der Wissenschaften in Wien und Director des Haus -, Hof- und Staatsarchivs Alfred Ritter v. Arneth, Direktor der ungarischen Meisterschule für Malerei in Budapest, Professor Julius Benczur, Präsidenten der statistiscen Central-Comission Karl Freiherr Czörnig v. Czernhausen, Großwardeiner Domherrn, Titular- Abte und Sekretär der ungarischen Akademie der Wissenschaften Dr. Wilhelm Fraknoi; emeritierten Wiener Universitäts Professor Hofrathe Dr. Joseph Hyrtl, ungarischen Ministerialrathe und Director des ungarischen landesstatistischen Bureaus Karl Keleti, Minister a. D. Alfred Freiherrn v. Kremer, Director der Krakauer Kunstakademie, Maler Jan Matejko, emeritirten Wiener Universitäts-Professor Hofrathe Dr. Franz Ritter v. Miklosic, Maler Michael Munkacsy, Budapester Universitäts-Professor und Vorstand des dortigen Seminars für Geschichte Dr. Franz Salamon, Wiener Universitäts-Professor und Vorstand des Instituts für österreichische Geschichtsforschung Hofrathe Dr. Theodor Ritter v. Sickel, emeritirten Wiener Universitäts-Professor Dr. Lorenz Ritter v. Stein und dem Präsidenten des Reichsgerichtes Minister a. Dr. Joseph Unger. Quelle: Wiener Allgemeine Zeitung. Mittagblatt. Nr. 2685., 20 August 1887. Für Kunst und Wissenschaft., 1.o.
} 
oldalán Ferenc József mellképe látaható az alábbi mondattal: „Franciscus Josephus I. Austriae Imperator Rex Bohemiae etc. et Hungariae Rex Apostolicus“. A másik oldalán „literis et atribus“ felirat található. ${ }^{599}$ Az 1887-ben kitüntetett személyek névsorát augusztus 18-án, Ischlben hozták nyilvánosságra. Munkácsy neve mellett a következő méltató mondatot olvashatjuk: „Michael Munkácsy, dessen Ruf als Maler weltberühmt geworden ist.“600 Munkácsy Mihály, aki festőként lett világhírü.

Az „Aphotheose der Renaissance“ címü festménye az Allgemeine Kunst-Chronik kritikusának a tetszését is elnyerte. „[...] A legnagyobb művét hozta el nekünk. Vajon a legjelentősebbet is? Erről Párizsban azt vallják, hogy igen. Párizsban, ahol a képet már kiállították és ahol a mestert a Szalon nagydíja mellett a „Kommandeur der Ehrenlegion" kitüntetésben is részesítették.“601

\footnotetext{
${ }^{599}$ Magyar Nemzeti Galéria, Ehrenzeichen für Kunst und Wissenschaft. 2454/1929.

${ }^{600}$ HHStA.Obersthofmeisteramtsakten. (OHEA) Kt. 1113, r. 50/ 9/1 1886: 4929.

${ }^{601}$ Allgemeine Kunst-Chronik. (1890) Munkácsy und Makart. XIV. Bd. Nr. 22., zweites Oktoberheft 1890., 597.o. : „[...] Er hat uns sein größtes Werk gebracht. Ob auch sein bedeutendstes? Darüber herrscht in Paris, wo das Werk bereits ausgestellt war und dem Meister nebst der großen Medaille des Salons die Ernennung zum Kommandeur der Ehrenlegion eingebracht hat, [...] Ein Hymnus in Farben auf die „Wiedergeburt der Kunst“", das ist das Deckengemälde.“
} 


\section{8. Összefoglalás}

E dolgozat célja az volt, hogy az eddigi, föleg a müvészettörténeti megközelítés által dominált, Munkácsy Mihály életét és munkásságát bemutató szakirodalmat elsődleges forrásokra támaszkodó tényekkel kiegészítse. A disszertáció célja volt az is, hogy a szakirodalmat társadalom-, kultúr- és eszmetörténeti szempontokkal gazdagítsa és ezáltal közelebb hozza egymáshoz a művészettörténészeket és történészeket.

Kutatásunk középpontjában a Munkácsy Mihály Bécsben eltöltött időszakának alapos tanulmányozása állt, ami Munkácsyra mély nyomott hagyott és ami későbbi munkásságában is visszatükröződött. Munkácsy müvészi fejlődésének megértéséhez elengedthetetlen, hogy az eddig nem kutatott bécsi évet alaposabban is megismerjük. Kutatásunk másik célja pedig a Munkácsy müvészeti tevékenységével kapcsolatosan fennálló nem tisztázott vagy félreértett kérdések újboli megvizsgálása volt.

Ezen célokat remélhetőleg teljesítettük. A dolgozatban dokumentáltuk Munkácsy bécsi tartózkodását, amit a korábbi irodalom elhanyagolt vagy figyelmen kívül hagyott. Ez az első kísérlet arra, hogy Munkácsy levelei alapján az 1865-ös évet rekonstruáljuk.

Bécs Munkácsy későbbi életében is fontos szerepet játszott. A szakirodalomban megfogalmazott állítással ellentétben, miszerint Munkácsy művészi tevékenységét a Habsburg-udvar nem értékelte, megmutattuk, hogy a császári udvar Munkácsy mủvészetét igen nagyra értékelte, ami számos kitüntetésben nyilvánult meg. Még magyar nemesi címet is kapott. A legmagasabb császári megtisztelés jeleként Munkácsy készíthette el a Bécsi Müvészettörténeti Múzeum menyezetfreskóját. A szakirodalom szerint a menyezetfestmények Munkácsy virtuozitását mutatják. Mindenesetre a császári megbízás eredeti példányai azt igazolják, hogy Munkácsynak az elhunyt Hans Makart vázlatai alapján kellett dolgoznia. 
Összegzésképpen megállapítható, hogy a fiatal Munkácsy előtt a müvészetek világa Bécsben nyilt ki, amikor 1865-ben Than Mór ajánlólevelét Karl Rahlnak átadta. A Bécsi Akadémia szelleme jelentős hatással volt a fiatal ember fantáziájára. A régi velencei iskola és a nagy olasz festők, mint például Tiziano és Michel Angelo, festési technikája nagyban befolyásolták Munkácsy fejlődését. A bécsi tanulmányok Munkácsy későbbi életére is nagy hatást gyakoroltak. 21 évvel később Munkácsy vissszatért Bécsbe, ahol egy, a mủvészi pályafutását megkoronázó megbízást teljesített, amit a Rahltól tanult stílusban vitelezte ki. 


\section{Bibliográfia}

\section{Levéltári anyagok}

\section{$\underline{\text { Házi, Udvari és Állami Leveltár (Haus-, Hof- und Staatsarchiv) }}$}

HHStA. Obersthofmeisteramtsakten. Kt. 1113, r. 50/ 9/1 1886: 4929.

HHStA., Obersthofmeisteramtsakten Kt. 1113, r. 50/ 9 / 1, 1886:4929. Schreiben in Briefform. G. V. C. Prinzen zu Hochenlohe an den Maler Munkácsy.

HHStA: 5113 Szám/ eln. 21/12 880. Brief von Mihály Munkácsy. Paris am 16 Januar 1881.

HHStA: Archiv Franz - Joseph- Ordens. Kt.23. ,1873:641, F.J.O. Revers von Michael Munkácsy. 21. Februar 1874. Paris.

HHStA: Archiv Franz - Joseph- Ordens., Kt.23, 1873:641.,1, 5., 6.o.

HHStA: Archiv Franz -Joseph- Ordens. Kt.23. 1873:641. No. 641/ V. K. Revers von Karl von Telepy. 12. Januar 1874. Budapest

HHStA: BM. Akten. A 6059., Mór Than. 24. Februar 1862. Pest.

HHStA: Gesandtschaftsarchiv 5113 Szám/ eln. 21/12 880. am 16 Dezember 1880. Budapest.

HHStA: Gesandtschaftsarchiv, 384 szám/eln. am 5 Februar 1881. Budapest.

HHSA: Kabinetskanzlei - Vorträge 1878: 4252. Professoren - Kollegium der Akademie der bildenden Künste in Wien. 
HHStA: Kabinettskanzlei - Vorträge, 1880:4747. Verleihung des ung. Adels mit dem Prädikat von Munkács.

HHStA: Kabinettskanzlei - Vorträge,1873:4479. Franz-Josephs- Orden.

ÖSTA. HHStA. Oberstkämmeramt. Kt.703, r. 59/1, 1887:668. Prinzen zu Hohenlohe an den Maler Munkácsy, die Anfertigung des Deckengemäldes im Kunsthistorischen Museum zu Wien. 


\section{Bécsi Városi és Tartományi Leveltár (Wiener Stadt- und Landesarchiv)}

Wiener Stadt- und Landesarchiv. Material des Wiener Künstlerhauses. Nachlass von Karl Rahl.

Wladimir Aichelburg Manuskript zu den noch nicht gedruckten Bänden des Werkes „Das Wiener Künstlerhaus 1861 - 2001“

\section{Magyar Nemzeti Galéria}

Magyar Nemzeti Galéria, Adattár. 2092/75, 1879. „Die Kaiserin im Künstlerhaus.”

Magyar Nemzeti Galéria, Adattár. 2454/1929. „Ehrenzeichen für Kunst und Wissenschaft“، 2454/1929.

Magyar Nemzeti Galéria, Adattár. 2811/ 1929/4.F. Walther Ilges: Aus dem Nachlasse Munkacsys. Sonderdruck aus „Deutsche Revue“ Juli 1901., 3.o.

Magyar Nemzeti Galéria, Adattár. 2811/ 1929/6.F. Walther Ilges: Aus dem Nachlasse Munkacsys. Sonderdruck aus „Deutsche Revue“ Juli 1901. 3.o.

\section{Magyar Országos Levéltár}

Magyar Országos Levéltár-MOL. Fond: K. 21., 1880- 9751.

Magyar Országos Levéltár-MOL. Fond: K. 21., 1880- 9751., 18.o.

Magyar Országos Levéltár-MOL. K.21. 1880 - 9751. Báró Orczy Béla Ő Felsége személye körüli magyar királyi miniszter elöterjesztése.

Magyar Országos Levéltár-MOL. K21., 1880 - 9751. Elismervény.

Magyar Országos Levéltár-MOL. R227. Mihály Munkácsy levele unokahúgaihoz. 1865. március 10. (das richtige Datum wurde von der Verfasserin ausgeforscht) 
Magyar Országos Levéltár-MOL. R227. Mihály Munkácsy levele AngyalGyulához, 1871.

\section{Magyar Tudományos Akadémia Múvészettörténeti Kutató Intézet}

Magyar Tudományos Akadémia Művészettörténeti Kutató IntézetMDK.C.-I.-13/140.4. Dezsö Rózsaffy: „Az igazi Munkácsy“, Petrovics emlékkönyv. Budapest, 1934.

Magyar Tudományos Akadémia Művészettörténeti Kutató Intézet. Lektori jelentés dr. Czeglédi Imre A Lieb és a Reök-Röck család története címü tanulmányáról, MKCS C-I$92 / 3(1-2)$

Magyar Tudományos Akadémia Müvészettörténeti Kutató IntézetMDK-C-I-13/140,1. Rózsaffy : Munkácsi élete és müvészete címü elöadás kézirata. 13/144 1-50. Munkácsy Mihály élete és müvészete. Irta: Rózsaffy Dezsö.

\section{Országos Széchényi Könyvtár}

Országos Széchényi Könyvtár-OSZK., Kézirattár, Levelestár, Levél Ormos Zsigmondtól, Pesty Frigyeshez. 1858 - 1884, é. n.( Berlin Augusztus 20 kán 1858.)

Országos Széchényi Könyvtár-OSZK., Kézirattár, Levelestár. Levelek Munkácsy Mihálytól, unokahúgaihoz- Reök Júlia, Sarolta, Ilka und Gabriella. 1864. december 24.

Országos Széchényi Könyvtár-OSZK., Kézirattár, Levelestár. Telepy Károly levele, Jókai Mórnak 1858.

Országos Széchényi Könyvtár-OSZK. Kézirattár. Fond VIII/764. Ormos Zsigmondlevele Pulszky Ferencnek.

Országos Széchényi Könyvtár-OSZK., Kézirattár. Levelestár 1900/20., Ormos Zsigmond levele Pulszky Ferencnek. 
Országos Széchényi Könyvtár-OSZK., Kézirattár. Levelestár 1898/22, Ormos Zsigmond levele Pulszky Ferencnek.

Országos Széchényi Könyvtár-OSZK., Kézirattár. Levelestár.Munkácsy Mihály levele Ligeti Antalnak. 1. sz. levél., 1865. február 12.

Országos Széchényi Könyvtár-OSZK., Kézirattár, Levelestár.Munkácsy Mihály levele Ligeti Antalnak. 2. levél.

Országos Széchényi Könyvtár-OSZK., Kézirattár, Levelestár.Munkácsy Mihály levele Ligeti Antalnak. 3. sz. levél, 1865. március 15.

Országos Széchényi Könyvtár-OSZK., Kézirattár, Levelestár. Munkácsy Mihály levele Ligeti Antalnak. 4. sz. levél, 1865. április 15.

Országos Széchényi Könyvtár-OSZK., Kézirattár, Levelestár. Munkácsy Mihály levele Ligeti Antalnak. 5. sz. levél.

Országos Széchényi Könyvtár-OSZK., Kézirattár, Levelestár. Munkácsy Mihály leveleLigeti Antalnak. 6. sz. levél, 1865. október 20.,Gerendás.

Országos Széchényi Könyvtár-OSZK., Kézirattár, Levelestár. Munkácsy Mihály levele Ligeti Antalnak. 8. sz. levél, 1865. december 11. Békéscsaba.

Országos Széchényi Könyvtár-OSZK., Kézirattár, Levelestár. Munkácsy Mihály levele Ligeti Antalnak. 9. sz. levél, 1866. november 20.

Országos Széchényi Könyvtár-OSZK., Kézirattár, Levelestár. Munkácsy Mihály levele Ligeti Antalnak. 10. sz. levél

Országos Széchényi Könyvtár-OSZK., Kézirattár, Levelestár. Munkácsy Mihály levele Ligeti Antalnak. 11. sz. levél, 1867., München.

Országos Széchényi Könyvtár-OSZK., Kézirattár, Levelestár. Munkácsy Mihály levele Ligeti Antalnak. 12. sz. levél, 1867. április 8. 
Országos Széchényi Könyvtár-OSZK., Kézirattár, Levelestár. Munkácsy Mihály levele Ligeti Antalnak. 13. sz. levél, 1867. május 9.

Országos Széchényi Könyvtár-OSZK., Kézirattár, Levelestár. Munkácsy Mihály levele Ligeti Antalnak. 14. sz. levél, 1867. október.

Országos Széchényi Könyvtár-OSZK., Kézirattár, Munkácsy Mihály levele Ligeti Antalnak. 15. sz. levél (im Brief ist kein Jahr angegeben) 1867. München nach der Forschungsarbeit der Autorin.

Országos Széchényi Könyvtár-OSZK., Kézirattár, Levelestár. Munkácsy Mihály levele Ligeti Antalnak. 16. sz. levél.

Országos Széchényi Könyvtár-OSZK., Kézirattár, Levelestár. Munkácsy Mihály levele Ligeti Antalnak. 19. sz. levél, 1867. december 6., München.

Országos Széchényi Könyvtár-OSZK., Kézirattár, Levelestár. Munkácsy Mihály levele Ligeti Antalnak. 22. sz. levél ( im Brief ist kein Jahr angegeben) 1868. München.

Országos Széchényi Könyvtár-OSZK., Kézirattár, Levelestár. Munkácsy Mihály levele Ligeti Antalnak. 23. sz. levél, 1868. Düsseldorf.

Országos Széchényi Könyvtár-OSZK., Kézirattár, Levelestár. Munkácsy Mihály levele Ligeti Antalnak. 24. sz. levél, 1868. Düsseldorf.

Országos Széchényi Könyvtár-OSZK., Kézirattár, Levelestár. Munkácsy Mihály levele Ligeti Antalnak. 25. sz. levél, 1868. december 7.

Országos Széchényi Könyvtár-OSZK., Kézirattár, Levelestár. Munkácsy Mihály levele Ligeti Antalnak. 26. sz. levél, 1868. december.

Országos Széchényi Könyvtár-OSZK., Kézirattár, Levelestár. Munkácsy Mihály levele Ligeti Antalnak. 27. sz. levél, 1869. január 10.

Országos Széchényi Könyvtár-OSZK., Kézirattár, Levelestár. Munkácsy Mihály levele Ligeti Antalnak. 28. sz. levél, 1869. 
Országos Széchényi Könyvtár-OSZK.,Kézirattár, Levelestár. Munkácsy Mihály levele Ligeti Antalnak. 29. sz. levél, 1869. április 20.

Országos Széchényi Könyvtár-OSZK., Kézirattár, Levelestár. Munkácsy Mihály levele Ligeti Antalnak. 30. sz. levél, (Jahr ist nicht angegeben) 1869 Düsseldorf

Országos Széchényi Könyvtár-OSZK., Kézirattár, Levelestár. Munkácsy Mihály levele Ligeti Antalnak. 32. sz. levél, 1869.Düsseldorf.

Országos Széchényi Könyvtár-OSZK., Kézirattár, Levelestár. Munkácsy Mihály levele Ligeti Antalnak. 34. sz. levél, 1869. Düsseldorf.

Országos Széchényi Könyvtár-OSZK., Kézirattár, Levelestár. Munkácsy Mihály levele Ligeti Antalnak. 35. sz. levél, (im Brief ist kein Jahr angegeben), 1870 Düsseldorf.

Országos Széchényi Könyvtár-OSZK., Kézirattár, Levelestár. Munkácsy Mihály levele Ligeti Antalnak. 36. sz. levél, (im Brief ist kein Jahr angegeben), 1870, Düsseldorf.

Országos Széchényi Könyvtár-OSZK., Kézirattár, Levelestár. Munkácsy Mihály levele Ligeti Antalnak. 37. sz. levél, Paris, 1870. május 31.

Országos Széchényi Könyvtár-OSZK., Kézirattár, Levelestár. Munkácsy Mihály levele Ligeti Antalnak. 1864. december 27.

\section{Bécsi Városi és Tartományi Könnyvtár (Wiener Stadt- und Landesbibliothek).}

Wiener Stadt- und Landesbibliothek. Handschriftabteilung. I. N. 75962. Brief von Mór Than an seinem Freund Hoffman.

Wiener Stadt- und Landesbibliothek. Handschriftabteilung. Brief von Mór Than an seinem Freund Hoffman. I. N. 75962.

Wiener Stadt- und Landesbibliothek. N. 161.972. Munkácsy Mihály. 
Wiener Stadt- und Landesbibliothek. Handschriftenabteilung. I. N. 75961. Brief von Mór Than an seinem Freund.

Wiener Stadt- und Landesbibliothek. Handschriftenabteilung. I.N. 75.75966. Brief von Mór Than an seinem Freund I. N. 75965.

Wiener Stadt- und Landesbibliothek. Handschriftenabteilung. I.N. 75967. Brief von Mór Than an Hoffman.

\section{A Bécsi Szépmúvészeti Akadémia egyetemi levéltára (Universitätsarchiv der}

\section{$\underline{\text { Akademie der bildenden Künste Wien) }}$}

Universitätsarchiv der Akademie der bildenden Künste Wien, - Matrikel der im Studienjahr 1864/65 in der Meister- u.Vorbereitungsschuler für Maler, Bildhauer in der in der Architektur, Landschafts, Schule für kleinere Plastik, und Kupfersteherschule auf genommenen Zöglinge.

\section{Korabeli múvek}

Bömches, Friedrich (1874), Bericht über die Weltausstellung zu Wien. Im Jahre 1873. Herausgeben durch die Küstenländische Austellungs Comission in Triest.

Daun, Berthold (1909), Die Kunst Des XIX. Jahrhunderts Und Der Gegenwart. Verlag von Neufeld \& Renius, Berlin.

Csányi Károly (Ed.) (1907), A budapesti amateur gyüjtemények kiállításának lajstroma. A kiállítók névsora. Országos Magyar Iparművészeti Múzeum.

D. von Vincenti (1876), 262-263.0

Förster, Franz (1873), Illustrierter Wiener Fremdführer. 1873. Praktischer Wegweiser mit besonderer Berücksichtigung. Der Weltausstellung und aller Sehenswürdigkeiten und Grossem, ausführlichem Plane der Stadt, ferner Plänen. Wien. 
Frauberger, von Heinrich (1873), Biographische Lexicon der Wiener Weltausstellung 1873. Erster Band. Herausgeber Engel und Rotter. Wien.

Friedrich, Pecht (1877), Deutsche Künstler im Neunzehnten Jahrhundert. Studien und Erinnerungen. Nördlingen, Beck.

Gerő Ödön (1904), Budapest. „Uránia” Népszerű tudományos felolvasások 12. Hornyászky Viktor Császári és Királyi Udvarának Könyvnyomdája.

Gelléri Mór (1885), A kiállítások története, fejlődése és jövendőbeli rendszeresítése. Budapest.

Gill, Perry-Colin Cunningham (1999), Academies, Museums and Canons of Art. New Haven-London, Yale University Press, in association with The Open University.

Haack, Friedrich, (1905), Die Kunst des XIX. Jahrhunderts, Paul Neff Verlag -Carl Büchle, Stuttgart.

Hevesi, Ludwig (1909), Altkunst-Neukunst. Wien 1894 - 1908. Verlangsbuchhandlung Carl Konegen, Wien.

Hevesi, Ludwig von (1903), Oesterreichische Kunst in Neunzehnten Jahrhundert. E. A. Seemann, Leipzig.

Honismertető-Magyarország a bécsi 1873-diki közkiállításon. Különleges katalógus. A gazdaság, ipar, tudomány és müvészet kiállított tárgyaiból. II. rész. A kiállítók és tárgyaik lajstroma. Budapest, 1873.

Ilges, F. Walter (1899), M. Von Munkacsy, Verlag von Velhagen \& Klasing, Bielefeldund Leipzig.

Lauser, Wilhelm, (1885), Die Kunst in Oesterreich-Ungarn. II. Jahrgang.-Jahrbuch der „Allgemeinen Kunst - Chronik“, Makart und kein Ende. Verlag von Carl Graeser. Wien., 54.o. 
Lehmann, Ernst (1873), Führer durch die Kunsthalle der Weltausstellung in Wien. Alfred Hölder- Beck`sche Universität-Buchhandlung, Wien.

Lützow, Carl Friedrich Arnold von (1873), Kunst und Kunstgewerbe auf der Wiener Weltausstellung. E. A. Seemann, Leipzig.

Lützow, Carl Friedrich Arnold von (1889), K. K. Akademie der bildenden Künste. Katalog der Gemäldegaleri-Akademie der bildenden Künste. Wien.

Lützow, Carl Friedrich Arnold von (1900), Katalog der Gemäldegalerie. In zweiten Auflage neu bearbeiten von Josef Denja`c und Eduard Gerisch, Verlag der K. K. Akademie der Bildenden Künste. Wien.

Lyka Károly (Ed.) (1902), Müvészet, Régi magyar mecénások. I. évf. 3. szám.

Malonyai Dezsö (1898), Munkácsy Mihály élete és munkái. Singer és Wolfner. Budapest.

Mayer, August George (1882), Erinnerungen an Carl Rahl.: ein Beitrag zur Kunstgeschichte Wiens (1847-1865), Comissions Verlag, Von Lehmann \&Wenzel.

Meyer (1873), Meyers Reisebücher Wien. Weltausstellung 1873. Führer durch die Kaiserstadt und auf den Besuchtesten Routen. Österreich - Ungarn. Unter besonderer Berücksichtigung der Welt-Ausstellung. Hildburgmausen Bibliographisches Institut

Munkácsy, Michel von (1897), Erinnerungen. Die Kindheit. Mit einem Vorwort von Boyer d'Agen, Autorisierte Übersetzung aus dem Französischen von F. Walter Ilges. F. Fontane \& Co., Berlin.

Munkácsy Mihály (1897), Souvenirs: L’enfance, préface par Boyer D`Agen, Callman Lévy, Paris.

Munkácsy Mihály (1950), Emlékeim. Hungária, Budapest.

Pecht,Friedrich (1877), Deutsche Künstler des neunzehnten Jahrhunderts. Studien und Erinnerungen von Friedrich Pecht. Erste Reihe. Nördlingen. 
Pecht, Friedrich (1873), Kunst und Kunstindustrie auf der Wiener Weltausstellung 1873. Verlag der J. G. Tottalschen Buchhandlung. Stuttgart.

Pecht, Friedrich (1894), Aus Meiner Zeit, Lebenserinnerungen. Verlaganstalt für Kunst und Wissenschaft. Vormals Friedrich Bruckmann. Zweiter Band. München.

Schauff Napomuk János (1794), Allgemeine Begriffe von Künsten und Künstlern angewendet auf die bildende Künste. Pozsony.

Vajda Viktor (1870), Müvészet és politika. Képek a magyar társadalomból. Pest.

Weltausstellung 1873 in Wien. (1873) Liste der Königlich-Ungarischen RegierungsComissionen.(In alphabetischer Ordnung ), (Anhang zur Liste der inländischen Comissionen) Kaiserlich-Königliche Hof- und Staatsdruckerei Wien

Weltausstellung 1873 in Wien. Kunst-Catalog. (1873), 1 Auflage. Wien.

Weltausstellung 1873 in Wien. Liste der Mitglieder der Internationalen Jury (1873), (Nach Gruppen alphabetisch geordnet), I. Ausgabe, Ausgaben am 20 Juni 1873.

Weltausstellung 1873 in Wien. Offizielle Programme und Publicationen. Nr.76.

Weltausstellung 1873 in Wien. Offizielle Programme und Publicationen, Nr. 46. Concours für die Anfertigung der Preismedaillen.(Verzeichnis der Mitglieder der Jury zur Beurteilung der Modelle.) 1.o.

Weltausstellung 1873. In Wien. (1873), Amtliches Verzeichniss der Austeller welchen von der Internationalen Jury Ehrenpreise. Verlag der General-Direction. Druck der Kaiserlich-Königlichen Hof- und Staatsdruckerei Wien.

\section{Folyóiratok}

Allgemeine Kunst-Chronik. (1886), X. Band., Nr.34. Die Kunst in den Ungarischen Provinzstädten.- Die Jugendarbeiten. Drei Porträts - in Fünfkirchen (1864.,) 21. Aug. 681-683.o. 
Allgemeine Kunst-Chronik. ${ }^{602}$ (1890), XIV. Band. Nr.22., Munkácsy und Makart zweites Oktoberheft. 598.o.

Allgemeine Kunst-Chronik. Allgemeine Literatur-Chronik-Beilage zur Allgemeine Kunst-Chronik. (1886), X. Band, Nr.35., Berühmt gewesen.713-714.o.

Budapesti Szemle ${ }^{603}$ (1891), LXV. évf. Antal Ligeti: Munkácsy Mihály ifjúsága. 321344.o.

Magyar Salon (1886), V. kötet, 6. szám. Ed.:Fekete József, Hevesi József. Zsilinszky Mihály: Munkácsy Gyerekkorából.

Kunst-Chronik. Beiblatt zur Zeitschrift für bildende Kunst. 17. Jahrgang, Nr.15., 1882, Die internationale Kunstausstellung in Wien. 233.o.

Lyka Károly (1904), Müvészet (1835), XI.évf., 130.o.

Lyka Károly (1904), Müvészet (1841), III.évf., 103.o.

Lyka Károly (1904), Művészet, III. évf., 3. szám, Bayer József: A Pesti Mủegylet kezdeményezői és első megtámadói.

Oesterreichische-Ungarische Revue ${ }^{604}$ (1865), III. Jg., V. Bd., Kunst und Kunstverein in Ungarn.

Oesterreichische Ungarische Revue (1865), III. Jg.,IV. Bd. Kunst und Kunstvereine in Wien. 243-252.o.

Recensionen und Mittheilungen über bildende Kunst (1863), Biographische Skizze von Friedrich Hottner: Karl Rahl.

\footnotetext{
${ }^{602}$ Allgemeiene Kunst-Chronik,

${ }^{603}$ Budapesti Szemle 1840-1892.

604 Oesterreichisch-Ungarische Revue, 1886-1894. Monatschrift für gesamten Kulturinteresse der Österreichischen-Ungarischen Monarchie.
} 
Waldheim's Illusttrierte Blätter (1864), Die Festung Kufstein und ihr berüchtigter Insasse, 165-166.o.

Zeitschrift für bildende Kunst, (1892), XXVII. Bd. III. Das Kunsthistorische Hofmuseum in Wien. 101-102.o.

Zeitschrift für bildende Kunst, Kunst Chronik, (1882), Beiblatt zur Zeitschrift für bildende Kunst. Preisverteilungen. Preisverteilung bei der internationalen Ausstellung in Wien. 650.o.

Zeitschrift für bildende Kunst, Kunst Chronik, (1882), Beiblatt zur Zeitschrift für bildende Kunst. Nr.12., Munkacsys „Cristus vor Pilatus“ 195-196.o.

Zeitschrift für bildende Kunst, Kunst Chronik, (1882), Beiblatt zur Zeitschrift für bildende Kunst. Nr. 15.-, Die Internationale Kunstausstellung in Wien. 233-236.o.

Zeitschrift für bildende Kunst, Kunst Chronik, (1882), Beiblatt zur Zeitschrift für bildende Kunst. 17.Jg. Nr. 16., Österreichische sKunstverein - Munkácsys „, Cristus vor Pilatus“,257-260.o.

Zeitschrift für bildende Kunst, Kunst- Chronik. (1882), Beiblatt zur Zeitschrift für bildende Kunst. 17. Jg., Nr. 15., Die internationale Kunstausstellung in Wien. 233.o.

Zeitschrift für bildende Kunst. (1871), VII: Jg, Nr.4.,-Personalnachrichten - Michael Munkácsy in Düsseldorf. 1.Dezember, 65-67.o.

Zeitschrift für bildende Kunst. (1872), VII. Jg., Nr.7., 12 Januar, - Wiener Weltausstellung-(Preismedaillen), 132-134.o.

Zeitschrift für bildende Kunst. Kunst - Chronik (1872), Beiblatt zur Zeitschrift für bildende Kunst. VII. Jg., Nr.8, 26. Februar 1872.

Zeitschrift für bildende Kunst. Kunst - Chronik. (1870), Beiblatt zur Zeitschrift für bildende Kunst. V. Jg., Nr.1., Der „Salon“ von 1870. 1 Juli 1870, 149-152.o. 
Zeitschrift für bildende Kunst. Kunst-Chronik. (1870), Beiblatt zur Zeitschrift für bildende Kunst. V. Jg., Zwei neue Bilder von Hans Makart. 193.o.

Zeitschrift für bildende Kunst. Kunst-Chronik. (1870), Beiblatt zur Zeitschrift für bildende Kunst. V. Jg., Kunstvereine, Sammlungen und Ausstellungen. B. Düsseldorf. 94.o.

Zeitschrift für bildende Kunst. Kunst-Chronik. (1870), Beiblatt zur Zeitschrift für bildende Kunst. V. Jg., Nr.16., Vermischte Kunstnachrichten.-Michael Munkácsy har für sein Bild „Die letzte tage eines Verurteilten“ im Pariser Salon eine Medaille erhalten. 3 Juni, 137.o.

\section{Újságok}

(Nr.1. inclusive 90.) Kaiserlich-Königliche Hof und Staatsdruckerei. 1873.

Fremdenblatt $^{605}$ (1865), XIV. Jahrgang, Nr.187. Wien, 9. Juli 1865.

Neue Freie Presse ${ }^{606}$ (1865), Nr.190., Karl Rahl, 11. Juli.1865.

Neue Freie Presse (1865), Nr.309., Karl Rahl, 10. Juli 1865.

Neue Freie Presse (1865), Nr.313., Karl Rahl, 13.Juli.1865.

Neues Wiener Tagblatt ${ }^{607}$ (1873), Nr.157., Vom Lesetisch. Neue Ausstellungskataloge. Juni 1873., 4.o.

Ost-Deutsche Post ${ }^{608}$ (1865), Nr.189., Karl Rahl, 10. Juli. 1865.

Ost-Deutsche Post (1865), Nr.191., Rahl's Leichenbegängniss, 13.Juli.1865.

\footnotetext{
${ }^{605}$ Fremdenblatt, von 1.7. 1847 bis 23. 3. 1919 erscheinender Tageszeitung in Wien.

${ }^{606}$ Neue Freie Presse 1864-1938.

${ }^{607}$ Neues Wiener Tagblatt 10. März 1867-7 April 1945.

${ }^{608}$ Ost-Deutsche Post, $1848-1866$.
} 
Städtische Pressburger Zeitung ${ }^{609}$ (1873), Nr.157., Die ungarische WeltausstellungsCommission, 10. Juli 1873.

Städtische Pressburger Zeitung (1873), Nr.192., Weltausstellung 1873, An Ungarn verliehene Medaillen und Anerkennungsdiplome. Verzeichnis der Aussteller. Ehrenpreise. 22. August 1873.

Städtische Pressburger Zeitung (1873), Nr.143.,-Die Ungarischen Jury - Mitglieder der Wiener Weltausstellung, 24. Juni 1873.,1-2.o.

Städtische Pressburger Zeitung (1873), Nr.190., Weltausstellung12. Aug. 1873., 2.o.

Städtische Pressburger Zeitung (1873), Nr.192., Weltausstellung 1873., 22. August1873., 2.o.

Weltausstellung 1873 in Wien. Offizielle Programme und Publicationen. Nr.76.

Wiener Abendpost (1865), Nr.155., Beilage zur Wiener Zeitung10.Juli 1865., 619.o.

Wiener Abendpost (1865), Nr.81., Beilage der Wiener Zeitung.-Samstag, 8. April. 1865., 322.o.

Wiener Allgemeine Zeitung (1882), Nr.886., Preisvertheilung der internationalen Kunst-Ausstellung, 10. Aug. 1882., 5.o.

Wiener Allgemeine Zeitung (1882), Nr.875, Sechsuhr-Abendblatt, Preis-Zuerkennung der internationalen Kunstausstellung. 5. Augustus 1882. 6.o.

Wiener Allgemeine Zeitung (1882), Preisvertheilung der internationalen Kunst Ausstellung. Nr. 884., 14. August 1882, 2.o.

Wiener Allgemeine Zeitung (1882), Tagesbericht, Internationale Kunst - Ausstellung. Nr.872., 2. August 1882, 5.o.

\footnotetext{
${ }^{609}$ Städtische Pressburger Zeitung, 14.7.1764 bis 1929. Die erste periodische Zeitung war in Ungarn.
} 
Wiener Allgemeine Zeitung (1887), Nr.2685., Sechsuhr-Abendblatt. 20. August 1887., Wien, 1-2.o.

Wiener Allgemeine Zeitung (1887), Nr.2686., Morgenblatt. Inland- Das Ehrenzeichen für Kunst und Wissenschaft., 21. August 1887. 2.o.

Wiener Weltausstellungs-Zeitung (1873), III. Jahrgang, Nr.187., Weltausstellung Die Mitglieder der internationalen Jury., 28 Juni 1873.

Wiener Weltausstellungs-Zeitung (1873), III. Jg., Nr.1., Zur Raumvertheilung in der Kunsthalle.

Wiener Weltausstellungs-Zeitung (1873), III. Jg., Nr.1., Über die Raum-und Lichtverhältnisse in der Kunsthalle.

Wiener Weltausstellungs-Zeitung (1873), III. Jg., Nr.145., Bilder vom Ausstellungsplatze, Das ungarische Weinhaus, 7. Mai, 1873.

Wiener Weltausstellungs-Zeitung (1873), III. Jg., Nr.146, Weltausstellungs-Notizen, Oesterreich - Ungarn, 8. Mai 1873.

Wiener Weltausstellungs-Zeitung (1873), III. Jg., Nr.159., Aus der Kunsthalle III., 24 Mai 1873.

Wiener Weltausstellungs-Zeitung (1873), III. Jg., Nr.171, Aus der Kunsthalle VI., 8. Juni 1873.

Wiener Weltausstellungs-Zeitung (1873), III. Jg., Nr.196, Die Arbeiten der Jury, 6. Juli 1873.

Wiener Weltausstellungs-Zeitung (1873), III. Jg., Nr.223, Bilder vom Ausstellungs Platze. Die ungarische Csárda, (Das ungarische Weinhaus), 9. August, 1873.

Wiener Weltausstellungs-Zeitung (1873), III. Jg.,Nr.176. Wien, Bilder vom Ausstellungsplatze XXXVIII. Die Kunsthalle. 15. Juni 1873. 
Wiener Weltausstellungs-Zeitung (1873), III. Jg., Nr.1., Vorbereitungen zur der Wiener Weltausstellung. Oesterreich-Ungarn, (Hohe fürstliche Gäste.) 8.Jänner 1873.

Wiener Weltausstellungs-Zeitung (1873), III. Jg. Nr.137. Beilage: Ungarn in der Weltausstellung. 27. April 1873.

Wiener Weltausstellungs-Zeitung(1873), III. Jg., Nr.101., Franz Josef I., Kaiser von Österreich, König von Ungarn und Böhmen. 8. Jänner 1873.

Wiener Weltausstellungs-Zeitung. (1873), III. Jg., Nr.1., Ungarn. Pest (Das Executiv Comité der ungarischen Landes-Commission für die Wiener Weltausstellung)

Wiener Weltausstellungs-Zeitung (1873), III. Jg., Nr.130., Die Raumvertheilung in der Kunsthalleund in den Pavillons des amateurs.

Wiener Zeitung (1864), Nr.149.,Zur Tagesgeschichte, 16 Juni. 1864., 878.o.

Wiener Zeitung (1865),. Nr. ,Zur Tagesgeschichte, 11. februar 1865., 465.o.

Szabó László (1989), A művészeti oktatás kérdése Magyarországon a 19. század elején. Ars Hungarica, 1989, 2. szám. 133-146.o.

Borsszem Jankó, 6. évfolyam. 277. szám, 1873. április 20., High Life Bécsből; Beust, a lantos búcsúja Bécstől; Bécsi kiállítás.

Borsszem Jankó, 5. évfolyam, 214. szám, 1872. február 4., Katinka grófnő.

Borsszem Jankó, 6. évfolyam, 295. szám, 1873. augusztus 31., Közkiállítási szótár.

Borsszem Jankó 6. évfolyam, 284. szám., 1873. június 8., A Közkiállításon; Vindobona és a Nagy Világ

Borsszem Jankó, 6. évfolyam, 296.szám, 1873. augusztus 31., Közkiállítási szótár.

Borsszem Jankó, 6. évfolyam, 302. szám, 1873. október 12., Están es Sanyi a bécsi közkiállításon.

Borsszem Jankó, 6. évfolyam, 304. szám, 1873. október 26., A Kiállításból.

Borsszem Jankó, 6. évfolyam, 274. szám, 1873. március 30., Magyarország a világtárlaton; Népszerủ felolvasások. III. Pulszky Ferencz. 
Borsszem Jankó, 6. évfolyam, 295. szám, 1873. augusztus 24., Están és Sanyi a bécsi közkiállításon

Borsszem Jankó, 1872. 5.évfolyam, 243.szám, 1872. augusztus 25., A bécsi világkiállításra küldendő nemzeti tárgyak.

Borsszem Jankó, 6. évfolyam, 277. szám, 1873.április 20., Németh Imre a közkiállitáson. m. k. biztos.

Borsszem Jankó, 6. évfolyam, 300. szám, 1873. szeptember 28., Están és Sanyi a bécsi közkiállításon.

Borsszem Jankó, 6. évfolyam, 295. szám, 1873. augusztus 24., A Közkiállításról. 


\section{Másodlagos források}

Aichelburg, Wladimir (1986), Das Wiener Künstlerhaus 1861-1986. 125 Jahre in Bilddokumenten. Kunstverlag Wolfrum, Wien.

Bachler, Karl (1972), Gemalte Theatervorhängein Deutschland und Österreich. Bruckmann, München.

Bakó Zsuzsa, Sz. KürtiKatalin, Ónody, Magdolna (2005), Munkácsy, Neografia, Szlovákia,Tóth Könyvkereskedés és Kiadó Kft., Debrecen.

Bakó Zsuzsanna (2012), Munkácsy. Magic \& Mystery. Kinizsi Nyomda Kft., Debrecen.

Bakó Zsuzsanna (2008), Munkácsy Mihály. Magyar Nemzeti Galéria, Kossuth Kiadó, Budapest.

Dr.Bakó Zsuzsanna (1994), Munkácsy Békéscsabán. Munkácsy Mihály Emlékház.

Bauer, Franz J. (2004), Das „lange“ 19. Jahrhundert.(1789-1917) Profil einer Epoche. Philipp Reclam jun., Stuttgart.

Benkö Samu (1974), Napló 1846. A fiatal Kemény Zsigmond naplója. Magyar Helikon, Budapest.

Bényi László-B. Supka Magdolna, (1953) Zichy Mihály. Müvelt Nép Könyvkiadó. Budapest.

Biedermann, Birgit (2001), Bürgerliches Mäzenatentum Im 19. Jahrhundert. Die Förderung Öffentlicher Kunstwerke Durch Den Kunstverein für Die Rheinlande Und Westfalen. Michael Imhof Verlag. Petersberg.

Blaskóné Majkó Katalin, Szőke Annamária ed. (2002), A Mintarajztanodától a Képzőművészeti Főiskoláig. Magyar Képzőművészeti Egyetem, Budapest. 
Bled, Jean Paul (2002), Wien. Residenz, Metropole, Hauptstadt. Kapitel 5.,Die Altstadt Und Die Vorstädte. Böhlau Verlag. Ges. m. b. H. \& Co. KG., Wien-Köln-Weimar.

Boetticher, Friedrich von (1974), Malerwerke des Neunzehnten Jahrhunderts, Zweite Band,- Erste Hälfte. (Mayer-Rybkowski) Boetticher’s Verlag, Drezden.

Bömches, Friedrich (1874), Bericht über die Weltausstellung zu Wien. Im Jahre 1873. Herausgeben durch die Küstenländische Austellungs Comission in Triest.

Bonniot, Roger (1994), L'Influence de Gustave Courbet Sur La Peinture Allemande De La Seconde Moitié Du XIXe Siécle. Edition du Musée Courbet, á l'occasion de l’exposition: «les oeuvres de Courbet en visite á Hüfingen», ville jumelée.

Blaskóné Majkó Katalin, Szőke Annamária ed. (2002), A Mintarajztanodától a Képzőművészeti Főiskoláig. Magyar Képzőművészeti Egyetem, Budapest.

Cennerné Wilhelm B. Gizella (1982), Than Mór 1828-1899., A Realizmus magyar mesterei. Képzőművészeti Kiadó, Budapest.

Czeglédi Imre (Ed.) (1976), Levelek Munkácsyhoz, Munkácsytól. Bibliotheca Bekesiensis 12., Békéscsaba.

Czeglédi Imre (1975), Munkácsy Békéscsabán. Békéscsaba Város Tanácsa. Békéscsaba. Farkas Zoltán (1941), Munkácsy Mihály. Országos Magyar Szépművészeti Múzeum. Farkas Zoltán (1943), Munkácsy Mihály, Szikra Nyomda, Budapest.

Farkas Zoltán ed. (1952), Munkácsy Mihály válogatott levelei. Müvelt Nép Könyvkiadó.

Farkas Zsuzsanna (2009) Embermásoló. Borsos József festőművész fényképeinek története. Magyar Fotográfiai Múzeum, Kecskemét.

Fleischer Gyula (1935), Magyarok a Bécsi Képzömüvészeti Akadémián. Budapest.

Gergely András (1998), 19. Századi Magyar Történelem. 1790-1918. Korona Kiadó, 
Budapest.

Genthon István (1935), Az új magyar festőmüvészet története 1800-tól napjainkig. Magyar Szemle Társaság. Budapest.

Gergely András (Ed.) (2003), Magyarország Története a 19. Században,Osiris Kiadó. Budapest.

Gerlach, Peter (1994), Vom realen Nutzen idealer Bilder, Kunstmarkt und Kunstvereine. (Vorträge gehalten bei dem Interdisziplinären Kolloquium „Kunsvereine: Gründungsgeschichte, Wirken und Wirkungsgeschichte 2, 150. Jahrestag des Kölner Kunstverenes. Köln 6.-8.10. 1989.) Aachen.

Gosztonyi Ferenc (Ed.) (2005), Munkácsy A Nagyvilágban. Munkácsy In The World. Magyar Nemzeti Galéria - Szemimpex Kiadó. Budapest.

Günter Natter (1990), Kaiserliche Ankaufspolitik und staatliche Kunstförderung, In: Gott erhalte Österreich. Religion und Staat in der Kunst des 19. Jahrhunderts. Ausstellung in Schloss Halbturn.

Gyáni Gábor, Kövér György, (1998), Magyarország Társadalomtörténete. A reformkortól a I. Világháborúig. A művelődés rétegei. Osiris Kiadó, Budapest.

F. Széphelyi György (1977) Lektori Jelentés, Budapest.

H. Kohut Mária (1971), Források Budapest Történetéhez 1873-1919., A Főváros Levéltárának forráskiadványa, Kossuth Nyomda, Budapest.

Hanák Péter (1988), A Kert és a Mühely, Gondolat Könyvkiadó, Budapest.

Hanák Péter ed. (1975), Magyarország az Osztrák-Monarchiában. Magyarország a Monarchiában. Túlsúly vagy függőség. 291-339.o. Budapest.

Henszlmann Imre (1990), Válogatott képzömüvészeti irások. (Ed.) Tímár Árpád, MTA. Müvészettörténeti Kutató Csoport, Budapest. 
Horváth Hilda (1993), Adalékok a század eleji magyar mügyüjtés történetéhez. In: Müvészettörténeti Értesítő. Nr. 1-2., 27-39.o.

Horváth Hilda (2000), Iparművészeti kincsek Magyarországon. 8. o.

Johnston, M. William (1980), Österreichische Kultur-und Geistesgeschichte. Gesellschaft und Ideen im Donauraum 1848 bis 1938, Wien, Köln, Graz.

Julius, Mirko und Gerstenbrand, Alfred (1965), Geschichte um das Wiener Künstlerhaus, Das Haus und die Feste, Die Haus Herren, Die Gäste. Erzählt von Mirko Jelusich Gezeichnet von Alfred Gerstenbrand, Verlag Kremayer \& Schiriau /Wien

Kárai Petra, Veszprémi Nóra (2009), München magyarul. Magyar művészek Münchenben1850-1914. Anagraphic, Paukler Nyomda, Budapest.

Kismarty Lehner Jenö (1961), Lehner Ödön. Képzömüvészeti Alap Kiadóvállalata, Budapest.

Klusacek, Christine, Stimmer Kurt (1991)Josefstadt. Mohl Verlag, Wien.

H. Kohut Mária (1971), Források Budapest Történetéhez. 1873-1919.,A Föváros Levéltárának Forráskiadványa, Kossuth Nyomda, Budapest.

Kletecka, Thomas (2010), Paradigmawechsel in der österreichischen Kunstförderung des 19. Jahrhunderts. In: Milan Hlavačka, Magdaléna Pokorná and Tomáš W. Pavlíček eds. (2010), Collective and Individual Patronage and the Culture of Public Donation in Civil Society in the 19th and 20th Centuries in Central Europe.

Kövér György (Ed.), (1998), Magyarország Társadalomtörténete I.-II. A reformkortól az elsö világháborúig. Szöveggyüjtemény. Nemzeti Tankönyvkiadó.

Kövér György (1998), A piacgazdaság kiteljesedése. In: Gergely András (Ed.), A 19. Századi Magyar Történelem 1790-1918., 343-374.o.

Langensteinm York (1983), Der Münchner Kunstverein im 10. Jahrhundert: Ein Beitrag zur Entwicklung des Kunstmarktes und des Ausstellungswesens, München: UNI-Druck. 
Lázár Béla (1944), Munkácsy Mihály: 1844-1944, emlékek és emlékezések a müvész születésének századik évfordulójára. Folio, Budapest.

Lengyel György (1986), Die ungarische Wirtschaftselite im 19. und zum Anfang des 20. Jahrhunderts: Lebensbahnen des Generationen. In: Bácskai Vera ed. (1986), Bürgertum und bürgerliche Entwicklung in Mittel- und Osteuropa. II. kötet. Magyar Tudományos Akadémia. Közép- és Kelet-Európai Kutatási Központ. Budapest.

Lhotsky, Alphons (1941), Festschrift Des Kunsthistorischen Museums in Wien. 18911941. Verlag Ferdinand Beger Horn, Wien.

Lyka Károly (1922), A táblabíró világ müvészete: Magyar müvészet 1800-1850. Singer és Wolfner, Budapest.

Lyka Károly (1926), Michael von Munkácsy. Eligius Verlag, Budapest.

Lyka Károly (1927), Kis könyv a müvészetröl. Singerés Wolfner, Budapest.

Lyka Károly (1942), Nemzeti Romantika. Magyar Müvészet, 1850-1867. Singer és Wolfner Irodalmi Intézet Rt., Budapest.

Lyka Károly (1942), Magyar Müvészet 1800-1850: A táblabíró-világ müvészete. Singer es Wolfner Irodalmi Intézet Rt., Budapest.

Lyka Károly (1964), Munkácsy (1844-1900), A müvészet Kiskönyvtára. Budapest.

Lyka Károly (1964), Munkácsy 1844-1900, A Müvészet Kiskönyvtára. Képzömüvészeti Alap Kiadóvállalata, Budapest.

Lyka Károly (1928), Zichy Mihály emlékezete. Budapesti Szemle. 210. kötet. 608. Szám.

Magyar Történeti Társulat (1952), Emlékkönyv. Kossuth Lajos születésének 150. évfordulójára. II. Akadémiai Kiadó. Budapest.

Markowitz, Irene (1969), Die Düsseldorfer Malerschule. Malerei. Band 2., Düsseldorf. 
Nipperdey, Thomas (1972),Verein als soziale Struktur in Deutschland im späten 18. und frühen 19. Jahrhundert. In Hartmut Boockmann (ed): Geschichtswissenschaft und Vereinswesen im 19. Jahrhundert. Beiträge zur Geschichte historischer Forschung in Deutschland.

Pemsel, Jutta (1989), Die Wiener Weltausstellung von 1873. Böhlau Verlag, Wien, Köln.

Perneczky Géza (1970), Munkácsy. Corvina Verlag. Budapest.

Polenyák Ivett: Die Rolle des Mäzenatentums im Spiegel der österreichischen und ungarischen Kunstvereine im 19. Jahrhundert. Die englischen und deutschen Vorläufer.466-468.o. In: Milan Hlavačka, Magdaléna Pokorná and Tomáš W. Pavlíček eds. (2010), Collective and Individual Patronage and the Culture of Public Donation in Civil Society in the 19th and 20th Centuries in Central Europe, Prague.

Polenyák Ivett (2011), Munkácsy Mihály és Carl Rahl kapcsolata, (1865). In: Strausz Péter-Zachar Péter Krisztián ed. (2011), Történelmi Emlékezet és Identitás. 128-144.o.

Pölöskei Ferenc (1995), Az 1867-es Kiegyezés Alternatívái. Korona Kiadó, Budapest.

Pukánszky Béla (2000), Német Polgárság Magyar Földön. Kissebbségkutatás Könyvek. Utánnyomás. Első kiadás, 1940. Lucidus, Budapest.

Rabinovsky Máriusz (1952) A művészeti oktatás kezdetei Magyarországon. In: A Magyar Mủvészeti Munkaközösség Évkönyve 1951. Művelt Nép Könyvkiadó, Budapest.

Radnóti József (1929), Pesti pénzoligarchák. 107.o.

Révész Emese (2005), A magyar historizmus, A polgári és állami müpártolás új formái, Corvina, Budapest.

Romsics Ignác (1995), Magyarország Története a XX. Században. Osiris Kiadó, Budapest. 
Sas Andor (1927), Szabadalmas Munkács Város Levéltára. 1376-1850. A régi városi archivum törtenetének, anyagának éscsoportosítási rendjének ismertetése. Kiadja Munkács városa. Munkács.

Scheffler, Karl (1927), Europaeische Kunst im neunzehnten Jahrhundert. Band 1., Cassirer, Berlin.

Schaeffer, August (1917), 50 Jahre Wiener Künstler-Genossenschaft unter Kaiser Franz Joseph I, Manuscript, Stadtbibliothek Wien.

Schmidt, Rudolf (1951), Das Wiener Künstlerhaus. Eine Chronik 1861-1951. Gesellschaft Bildender Künstlers Wiens. Künstlerhaus Wien.

Schwarz, Walter A. (2005), Vergänglicher Glanz...“Altösterreichs Orden. Katalog zur Ausstellung des Österreichischen Staatsarchiv und der Österreichischen Gesellschaft für Ordenskunde (ÖGO) anlässlich deren 15- jährigen Bestandsjubiläums, Haus-, Hof- und Staatsarchiv, 5. Mai bis 7. Oktober 2005. Hrsg. Vom Österreicherischen Staatsarchiv.

Sedelmeyer, Charles (1914), Michael von Munkácsy. Paris.

Sinkó Katalin (2009), Nemzeti Képtár. In: Magyar Nemzeti Galéria Évkönyve 2008. XXVI, No. 11.

Sinkó Katalin (1995), A művészi siker anatómiája 1840-1900. In: Aranyérmek, ezüstkoszorúk. Müvészkultusz és müpártolás Magyarországon a 19. században. Kiállítási katalógus. Magyar Nemzeti Galéria. Budapest.

Sinkó Katalin (1981), A Magyar műgyüjtés 1850 után - a magángyűjteményi kiállítások tükrében. In: Válogatás magyar magángyüjteményekből. Kiállítási katalógus. Magyar Nemzeti Galéria. Budapest, 1981. október-november, 11- 29.o.

Szabó László (1989), A művészeti oktatás kérdése Magyarországon a 19. század elején. Ars Hungarica, 1989, 2. szám.

Székely András (1977), Mihály Munkácsy. Mit siebzehn farbigen Tafeln und dreißig einfarbigen Abbildungen, Henschelverlag- Berlin, Corvina-Budapest, Arkady- 
Warsawa.

Székely András (1979), Munkácsy. Corvina Verlag, Budapest.

Szerb Antal (1994), A magyar irodalom története. Budapest: Magvető. 11. Kiadás.

Színyei József (1893), Magyar Irók Élete És Munkái, II.kötet, Engel Gyula, 13101311.o.

Szívós Erika (2009), A magyar képzőművészet társadalomtörténete. 1867-1918.,

Szögi László, Kiss Mihály József (2003), Magyarországi diákok a bécsi egyetemeken és akadémiákon. 1849 - 1867. Budapest.

Szvoboda Dománszky Gabriella (1999), Az Eszterházy Képtár a magyar fővárosban:Tanulmányok Budapest múltjából, XXVIII. Budapest. 219-261.o.

Szvoboda Dománszky Gabriella (2001/2-3). A Pesti Müegylet története. Budapesti Negyed.

Szvoboda Dománszky Gabriella (1986), A budapesti falképfestészet vázlatos áttekintése (1803-1903). Müvészettörténeti Értesítő, 1986., 3-4. szám.

Urbanitsch, Peter (2010), Musikmäzenatentum in Wien im letzten Drittel des 19. Jahrhunderts. In: Milan Hlavačka, Magdaléna Pokorná and Tomáš W. Pavlíček eds. (2010), Collective and Individual Patronage and the Culture of Public Donation in Civil Society in the 19th and 20th Centuries in Central Europe.

Varga József (1977), Az élet szobra. Ady Endre Képzőmüvészeti írásai. Corvina Kiadó, Budapest.

Végvári Lajos (1958), Munkácsy Mihály élete és müvei. Akadémiai Kiadó, Budapest.

Végvári Lajos (1961), Munkácsy. Corvina, Budapest.

Végvári Lajos (1983), Munkácsy Mihály 1844-1900. Képzömüvészeti Kiadó, Budapest. 
Vörös Károly, Spira György (1978 ), Budapest Története. A Márciusi Forradalomtól az Őszirózsás Forradalomig. Akadémiai Kiadó, Budapest.

Vörös Károly (1979), Budapest legnagyobb adófizetői 1873-1917. Akadémiai Kiadó. Budapest.

Wagner, Walter (1967), Die Geschichte der Akademieder Bildenden Künste in Wien. Wien: Brüder Rosenbaum.

Wittman Zsuzsa-Velledits Lajos (1994), Munkácsy Mihály festőtechnikája és anyagai. In: Munkácsy Mihály (1844-1900), Nemzetközi Tudományos Emlékülés.

Zádor Anna ed. (1962), Magyar Művészet 1800-1945. A magyarországi müvészet a XIX. század első felében. A nemzeti művészet kezdetei.

\section{Kézikönyvek és lexikonok}

Bán Péter (1989) Magyar Történelmi Fogalomtár II. Gondolat Kiadó, Budapest.

Brockhaus Entzyklopädie (1993), Vierundzwanzig Bänden Fünfzehnter Band, NoeNor, Neunzehnte, völlig neu bearbeitete Auflage, F.A. Brockhaus Mannheim.

Czeike, Felix (2004), Historisches Lexikon Wien: in 5 Bänden, Band 3-4., Wien: Kremayr \& Scheriau, 1992-1997.

Czerny, Wolfgang (1993), Dehio-Handbuch, Wien II. bis IX. Bezirk, Wien: A. Schroll. 323-340.o.,VIII. Bezirk-Josefstadt., Wickenburggasse. 367-368.o.

Lexikon der Kunst (1989), Malerei, Architektur, Bildhauerkunst, Herder Freiburg, Basel, Wien.

Lexikon der Kunst (1993), Architektur, Bildende Kunst, Angewandte Kunst, Industrieformgestaltung, Kunsttheorie, Band V., Mosb-Q., E. A. Seemann Verlag, Leipzig. 
Mayer, Stefan und Musger, August (1975), Österreichisches Biographisches Lexikon 1815 - 1950, Redigiert von Eva Obermayer - Marnach, VI. Band, Herausgeben von der Österreichischen Akademie der Wissenschaften, Wien.

Paffrath, Hans (1998), Lexikon der Düsseldorfer Malerschule 1819-1918. Band 2., Haach-Murtfeldt, München: Bruckmann.

Thieme-Becker Künstlerlexikon. (1934), XXV., Bd., Allgemeines Lexikon der Bildenden Künstler von der Antik bis zur Gegenwart. Munkácsy Mihály. 271-272.o., Begründet von Ulrich Thieme und Felix Becker. Herausgeben von Hans Vollmer, Leipzig, Verlag von E. A. Seemann,

Zádor Anna, Genthon István (Ed.), (1967), Müvészeti Lexikon. 3. kötet, L-Q., Akadémiai Kiadó, Budapest. 


\section{Saját publikációk}

Polenyák, Ivett (2010), Die Rolle des Mäzenatentums in Österreich - Ungarn im Spiegel der Kunstvereine, in: Hlavacka, M., Pokorná, M., T.W. Pavlícek (eds): Collective and Individual Patronage and the Culture of Public Donation in Civil Society in the 19th and 20th Centuries in Central Europe. The Institute of History Prague, Prága, 2010, 466-478 o.

Polenyák, Ivett (2011), Munkácsy Mihály, avagy művészi hírnév és nemesség, in Antos B., Tamás Á. (eds): Szemelvények ötszáz év magyar történelméből, Szegedi Tudományegyetem, Szeged, 2011, 51-59 o.

Polenyák, Ivett (2012), Munkácsy Mihály és a korabeli magyar festőelit az 1873- as bécsi világkiállításon, AETAS, 27(1), 159-176 o.

Polenyák, Ivett (2012), The Influence of the Venetian Scool on the development of Hungarian painting arts, as intermediated, in: Conference proceedings, International Institute of Social and Economic Sciences, Palermo, Sicily, 2012, április 15-18. ISBN: 978-80-905241-0-1, 254-259 o.

Polenyák, Ivett (2012), The Vienna Universal Exibition 1873: the art of Mihály Munkácsy in light of the German Criticism, in: In: Brisova, K., Knejp J. (eds) Changes of Central Europe Since the middle of 18th century to present, conference proceedings, International conference of doctoral candidates, Ostrava, 37-45 o.

Polenyák, Ivett (2012), Munkácsy Mihály és Karl Rahl kapcsolata (1865) - Történészi rekonstrukció a bécsi anyagok tükrében, in: Történelmi emlékezet és identitás. Tanulmányok, Heraldika Kiadó, 2012, 128-144 o. 